\author{
UNIVERSIDADE DE SÃO PAULO \\ FACULDADE DE EDUCAÇÃO \\ PROGRAMA DE PÓS-GRADUAÇÃO EM EDUCAÇÃO
}

LÍVIA ALONSO TAGLIARI

CADERNOS ANALÓGICOS E DIGITAIS: USOS E DESUSOS DOS SUPORTES DE ESCRITA NO ESPAÇO ESCOLAR 
LÍVIA ALONSO TAGLIARI

\section{CADERNOS ANALÓGICOS E DIGITAIS: USOS E DESUSOS DOS SUPORTES DE ESCRITA NO ESPAÇO ESCOLAR}

Dissertação apresentada ao à Faculdade de Educação da Universidade de São Paulo (FEUSP) para obtenção do título de Mestre em Educação.

Área de Concentração: Formação, Currículo e Práticas Pedagógicas.

Orientadora: Profa. Dra. Rita de Cassia Gallego. 
Autorizo a reprodução e divulgação total ou parcial deste trabalho, por qualquer meio convencional ou eletrônico, para fins de estudo e pesquisa, desde que citada a fonte.

Tagliari, Lívia Alonso

Cadernos analógicos e digitais: - usos e desusos

dos suportes de escrita no espaço escolar / Lívia

Alonso Tagliari; orientadora Rita de Cassia

Gallego. -- São Paulo, 2021.

$177 \mathrm{p}$.

Dissertação (Mestrado - Programa de Pós-Graduação Formação, Currículo e Práticas Pedagógicas) -

Faculdade de Educação, Universidade de São Paulo, 2021 .

1. suporte de escrita. 2. caderno escolar. 3. caderno digital. 4. cultura escolar. 5. tecnologia e educação. I. Gallego, Rita de Cassia, orient. II. Título. 
Nome: TAGLIARI, Lívia Alonso

Título: Cadernos analógicos e digitais: usos e desusos dos suportes de escrita no espaço escolar.

Dissertação apresentada ao à Faculdade de Educação da Universidade de São Paulo (FEUSP) para obtenção do título de Mestre em Educação.

Aprovada em: 02 de setembro de 2021

Banca Examinadora

Profa. Dra. Rita de Cassia Gallego

Instituição: Universidade de São Paulo (USP)

Julgamento:

Profa. Dra. Ana Chrystina Venancio Mignot

Instituição: Universidade do Estado do Rio de Janeiro (UERJ)

Julgamento:

Profa. Dra. Lilian Cassia Bacich Martins

Instituição: Instituto Singularidades

Julgamento: 
Aos meus pais. 


\section{AGRADECIMENTOS}

Escrever uma dissertação é um processo árduo, intenso, desafiador e, ao mesmo tempo, uma preciosa e extraordinária oportunidade de avançar, crescer, transformar-se. Ao longo de todo o desenvolvimento do trabalho, pude contar com o apoio, o incentivo, a colaboração, a torcida e as vibrações de muitos, a quem, aqui, expresso minha enorme gratidão.

À Rita de Cassia Gallego, com afeto e esmero, pela orientação carinhosa, paciente, firme, desde os anos da graduação. Toda a minha gratidão carregada de admiração e respeito por todas as suas contribuições na minha formação como pesquisadora e como professora, me instigando com suas provocações, fortalecendo o meu fazer científico, impelindo-me sempre a buscar excelência.

À Ana Chrystina Venancio Mignot e à Lilian Bacich, pelas leituras atentas e minuciosas que resultaram em generosas críticas, sugestões e contribuições feitas no exame de qualificação.

Ao Programa de Pós-graduação em Educação da Universidade de São Paulo e aos professores do Programa.

Ao Colégio que abriu as portas com tanto acolhimento e solicitude, permitindo que a coleta de dados acontecesse.

Ao coordenador do departamento cultural e à coordenadora de área da Língua Portuguesa que me receberam tão bem na instituição, mostrando-se extremamente solícitos e disponíveis, acreditando no potencial da pesquisa.

Às professoras de Língua Portuguesa, três docentes inspiradoras, que compartilharam suas aulas comigo com tanta generosidade, dispuseram a participar e contribuir com essa pesquisa, não medindo esforços para que ela pudesse ser viabilizada ainda que de maneira virtual em meio a uma pandemia.

Aos alunos, que de modo tão gentil, solícito e generoso, aceitaram conversar sobre seus cadernos, compartilhar suas reflexões e um pouco de suas vidas como estudantes. Vocês foram fundamentais para que essa pesquisa acontecesse.

À Adriana Cury Sonnewend, gestora incomparável, que disponibilizou seus contatos, viabilizando conversas que foram essenciais para eu encontrar a escola e, consequentemente, realizar a pesquisa, estimulando-me e incentivando-me.

Aos funcionários da Biblioteca da Faculdade de Educação da USP, de modo especial à Daniela Pires, que se mostrou muito atenciosa e prestativa, especialmente quando a biblioteca estava fechada em virtude da pandemia, possibilitando-me o acesso aos materiais. 
À minha querida amiga Melina Otofuji Pereira pela parceria, o apoio e a amizade desde a graduação. Gratidão por tantas trocas. Mesmo eu não tendo sua presença diária, você se fez presente.

À Maria Isabel Capello Rezende, que, desde a graduação, é acolhimento, incentivo e doçura. Às pesquisadoras e parceiras de orientadora, Marina Costa, Milena Pedroso e Vanessa Marruche, com quem compartilhei questões científicas, aulas, eventos, desafios, aflições, e que também contribuíram e fizeram importantes sugestões nas orientações coletivas. Um agradecimento especial à Vanessa que foi fundamental durante a revisão desta dissertação.

À Lara Marin, amiga generosa e professora parceira, que, com muita gentileza e disponibilidade, leu e ofereceu importantes contribuições para este trabalho, oportunizando importantes momentos de troca e crescimento.

Aos amigos da vida, Marina e Murilo Pastorelli, que, em muitas conversas nada acadêmicas, incentivam-me a buscar meus objetivos, mostrando-me o valor de uma amizade verdadeira e se fazendo presentes cotidianamente, repletos de bom humor e alegria.

Às amigas e parceiras de profissão, Amanda Rana, Bianca Sgai, Gabriella Leme, Graziele Alves, Maiara Sela, que, com tanta paciência, ouviram-me, dividiram angústias, compreenderam a minha ausência nos momentos de escrita da dissertação e, acima de tudo, encorajaram-me e apoiaram-me.

Aos meus pais, Katia e Walter, pelo amor, o incentivo sem limites e o apoio incondicional, mostrando-me sempre o valor e a importância de seguir os sonhos. Gratidão por compreenderem a minha ausência mesmo vivendo sob o mesmo teto. À minha mãe, obrigada por ouvir meus desabafos e minhas angústias, oferecendo-me sempre uma palavra carinhosa de consolo e encorajamento, pelas inúmeras orações e vibrações, pela alegria a cada conquista e por cuidar e tentar contribuir para que os momentos de escrita acontecessem da maneira mais leve possível.

Ao meu irmão, Lucas, à minha sobrinha, Isabella, à minha tia, Joana e à minha avó, Elza, a Tata, que, mesmo sem ter muita dimensão desse processo, sempre me apoiaram, incentivaram e compreenderam a minha ausência. 
O caminho se faz ao andar. Para dar resposta a essas perguntas é necessário indagar e investigar. Refletir e contrastar.

Escrever e esperar. Esperar que o pensamento amadureça e esperar a resposta de outros. Nunca o silêncio. (FRAGO, 1998, p. 16) 


\section{RESUMO}

TAGLIARI, Lívia Alonso. Cadernos analógicos e digitais: usos e desusos dos suportes de escrita no espaço escolar. 2021. 177 p. Dissertação (Mestrado em Educação) - Faculdade de Educação, Universidade de São Paulo, São Paulo, 2021.

Esta dissertação apresenta os resultados da pesquisa, cujo objetivo foi verificar e analisar os usos e desusos dos cadernos escolares frente à presença das ferramentas digitais. Escolheu-se o caderno - analógico e digital - como objeto de pesquisa, devido a sua relevância para os estudos na educação, e em razão de ser uma fonte rica, por meio da qual é possível ter acesso a concepções implícitas em seus conteúdos e modo de utilização, como ensino, aprendizagem e escola, além de permitir saber sobre os alunos, professores, currículo e tempos (como em FRAGO, 2008; GVIRTZ, 2005; SANTOS, 2008b; MIGNOT, 2008). Investigou-se, então, a) se quando estão inseridas na escola, as tecnologias digitais apenas substituem o uso dos cadernos ou b) se acrescentam inovações e potencialidades a esse suporte de escrita, ou ainda c) se são utilizadas concomitantemente aos cadernos analógicos. Para tanto, realizou-se uma pesquisa de campo, durante o segundo semestre de 2019, em uma renomada escola particular da cidade de São Paulo, reconhecida por empregar tecnologias digitais expressivamente. Nesse período, aproximou-se da dinâmica e da rotina escolares ao se acompanhar aulas de três professores de Língua Portuguesa de sextos e sétimos anos e ler documentos e publicações da instituição. Ainda, a pesquisa contemplou o cenário do ensino remoto - consequência do fechamento das escolas, o qual foi imposto pela pandemia do novo Coronavírus em 2020 -, com vistas a averiguar se os cadernos de papel eram utilizados pelos alunos nas aulas virtuais e em quais momentos. Então, foram realizadas conversas informais com uma daquelas professoras (acompanhada no presencial), além de entrevistas com seis alunos e análise das fotografias de seus cadernos, sendo estas duas fontes nucleares. Outrossim, realizou-se a leitura, a sistematização e a análise de três documentos oficiais (Diretrizes Curriculares Nacionais, Base Nacional Comum Curricular e Currículo da cidade de São Paulo), para compreender suas prescrições sobre o uso das tecnologias nas escolas. Foram examinados, também, os dados do Cetic.br quanto à utilização das ferramentas digitais na educação. Tanto os documentos normativos quanto os dados da realidade permitiram situar a escola em que a pesquisa foi realizada - em termos dos usos das tecnologias -, distinguir os conceitos de inovação e mudança escolar (FULLAN, 2009; GHANEM JUNIOR, 2013) e discutir sobre as tecnologias digitais na escola (COLL; MONEREO, 2010; KENSKI, 2012; MORAN, 2018, para citar alguns). Assim, 
a partir da perspectiva dos estudos da cultura escolar (FRAGO, 1996; ESCOLANO, 1999; JULIA, 2001, por exemplo), observou-se que a escolha e o uso desses materiais fazem parte de uma complexa trama que envolve diversas dimensões, como espaço, tempo, professores e sujeitos. Verificou-se que os cadernos analógicos ainda se fazem presentes em uma escola que possui tablets como material obrigatório dos alunos e que, independentemente de se ter um contexto escolar completamente virtual no segundo momento da realização da pesquisa, foi possível observar isto: alguns estudantes aderiram aos cadernos digitais, outros transitaram, fazendo seus registros de aula em cadernos analógicos e anotações pessoais nos tablets, outros, ainda, usaram exclusivamente cadernos de papel.

Palavras-chave: suporte de escrita; caderno escolar; caderno digital; tablet; cultura escolar; cultura material escolar; tecnologia e educação; práticas escolares. 


\begin{abstract}
TAGLIARI, Lívia Alonso. Analog and digital notebooks: uses and disuses of writing supports in the school space. 2021. 177 p. Dissertação (Mestrado em Educação) - Faculdade de Educação, Universidade de São Paulo, São Paulo, 2021.

This thesis presents the results of the research, whose objective was to verify and analyze the uses and disuses of school notebooks against the presence of digital tools. The notebook analog and digital - was chosen as the object of this research, due to its relevance for studies in education, and because it is a rich source, through which it is possible to have access to implicit conceptions in its contents and mode of use, such as teaching, learning and school, in addition to allowing knowledge about students, teachers, curriculum and times (as in FRAGO, 2008; GVIRTZ, 2005; SANTOS, 2008b; MIGNOT, 2008). It was investigated, then, a) if when they are inserted in school, digital technologies only replace the use of notebooks or b) if they add innovations and potentialities to this writing support, or even c) if they are used concomitantly with analog notebooks. To this end, a field research was carried out during the second half of 2019, in a renowned private school in the city of São Paulo, recognized for using digital technologies expressively. During this period, we got closer to school dynamics and routine by following the classes of three sixth- and seventh-year-old Portuguese language teachers and reading documents and publications from the institution. Moreover, the research contemplated the scenario of remote learning - a consequence of the closing of schools, which was imposed by the new Coronavirus pandemic in 2020 -, with a view to ascertaining whether the paper notebooks were used by students in virtual classes and at what times. Then, informal conversations were held with one of those teachers (accompanied in person), as well as interviews with six students and analysis of photographs in their notebooks, these two being nuclear sources. Furthermore, three official documents were read, systematized and analyzed (National Curriculum Guidelines, Common National Curriculum Base and São Paulo City Curriculum), in order to understand their prescriptions on the use of technologies in schools. Data from Cetic.br regarding the use of digital tools in education were also examined. Both the normative documents and the reality data allowed us to situate the school in which the research was carried out - in terms of the uses of technologies -, distinguish the concepts of innovation and school change (FULLAN, 2009; GHANEM JUNIOR, 2013) and discuss about the digital technologies at school (COLL; MONEREO, 2010; KENSKI, 2012; MORAN, 2018, to name a few).
\end{abstract}


Keywords: writing support; school notebook; digital notebook; tablet; school culture; school material culture; technology and education; school practices. Thus, from the perspective of school culture studies (FRAGO, 1996; ESCOLANO, 1999; JULIA, 2001, for example), it was observed that the choice and use of these materials are part of a complex plot that involves several dimensions, as space, time, teachers and subjects. It was found that analog notebooks are still present in a school that has tablets as mandatory material for students and that, regardless of having a completely virtual school context in the second stage of the research, it was possible to observe this: some students joined to digital notebooks, others moved, making their class records in analog notebooks and personal notes on tablets, still others used exclusively paper notebooks.

Keywords: writing support; school notebook; digital notebook; tablet; school culture; school material culture; technology and education; school practices. 


\section{LISTA DE ILUSTRAÇÕES}

\section{FIGURAS}

Figura 1 - Octógono das dimensões do suporte de escrita ..................................................58

Figura 2 - Caderno analógico da Julia (no início do ensino remoto) .................................... 105

Figura 3 - Caderno digital da Julia (no fim do ano, meses depois do início da pandemia) ... 105

Figura 4 - Caderno físico com anotações de aula da Gabriela............................................. 107

Figura 5 - Caderno digital com anotações de estudos da Gabriela ...................................... 107

Figura 6 - Ficha com anotações da Roberta ................................................................... 110

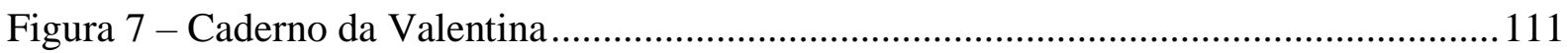

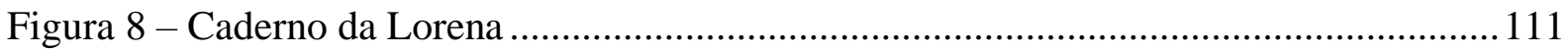

Figura 9 - Anotações de aula sobre Região Sudeste do Tomás (Parte 1) ............................. 115

Figura 10 - Anotações de aula sobre Região Sudeste do Tomás (Parte 2) ............................ 115

Figura 11 - Anotações de aula sobre Região Sudeste do Tomás (Parte 2) ........................... 116

Figura 12 - Anotações de aula sobre a região Sudeste da Gabriela (Parte 1) ........................116

Figura 13 - Anotações de aula sobre a região Sudeste da Gabriela (Parte 2) ........................117

Figura 14 - Anotações de aula sobre a região Sudeste da Valentina .....................................117

Figura 15 - Anotações de aula sobre a região Sudeste da Roberta ....................................... 118

Figura 16 - Anotações de aula sobre a região Sudeste da Lorena (Parte 1)........................... 118

Figura 17 - Anotações de aula sobre a região Sudeste da Lorena (Parte 2)........................... 119

Figura 18 - Anotações de aula sobre a região Sudeste da Lorena (Parte 3).......................... 119

Figura 19 - Anotações de aula sobre as reformas religiosas da Julia.................................... 120

\section{GRÁFICOS}

Gráfico 1 - Professores de escolas públicas urbanas, por percepção sobre barreiras para o uso

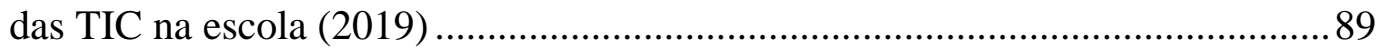

Gráfico 2 - Locais da escola com acesso à Internet, em escolas urbanas (2015-2018) ...........90

Gráfico 3 - Escolas urbanas, por velocidade da principal conexão com a Internet (2015-2019)

Gráfico 4 - Alunos de escolas urbanas por tipo de computador existente no domicílio (20112019) 
Gráfico 5 - Alunos de escolas urbanas, por redes sociais nas quais possuem perfil e utilizadas para trabalhos escolares (2015-2019)

Gráfico 6 - Professores de escolas públicas urbanas, por atividades pedagógicas realizadas com alunos e atividades realizadas com alunos a partir do uso de tecnologias (2018).97

Gráfico 7 - Professores de escolas urbanas, por tipo de recurso obtidos na internet para a preparação de aulas ou atividades com alunos (2019) .98

\section{QUADROS}

Quadro 1 - Trabalhos que fundamentam teoricamente o estudo sobre os cadernos escolares 39

Quadro 2 - Trabalhos que tratam das funções e uso dos cadernos escolares.

Quadro 3 - Trabalhos que tratam da materialidade dos cadernos escolares

Quadro 4 - Trabalhos que abordam os cadernos escolares como suportes de escrita e leitura 42

Quadro 5 - Trabalhos que tratam de tecnologias digitais na educação

Quadro 6 - Trabalhos que tratam de diversas abordagens tendo os cadernos escolares como objeto .45

Quadro 7 - Estudantes entrevistados de acordo com as suas séries .56

Quadro 8 - Excertos das falas dos alunos com os motivos pelos quais preferem os suportes digitais

Quadro 9 - Excertos das falas dos alunos com os motivos pelos quais preferem os suportes de papel..... 108

Quadro 10 - Excertos das falas dos alunos sobre o que anotam em seus cadernos 113

Quadro 11 - Excertos das falas dos alunos sobre a ideia de que quando escrevem aprendem melhor

Quadro 12 - Excertos das falas dos alunos sobre usar a caneta para o tablet faz com que utilizem mais a ferramenta

Quadro 13 - Excertos das falas dos alunos sobre compartilhar seus cadernos com seus colegas

Quadro 14 - Excertos das falas dos alunos sobre a motivação em fazer registros nos cadernos 135

Quadro 15 - Excertos das falas dos alunos que demonstram que o caderno é um instrumento para aprender.... 
Quadro 16 - Excertos das falas dos alunos que demonstram que o caderno é um instrumento

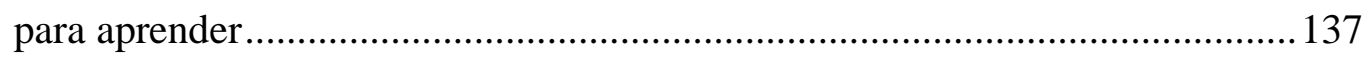

Quadro 17 - Excertos das falas dos alunos sobre a importância dos tablets......................... 138

Quadro 18 - Excertos das falas dos alunos que tratam sobre a função de cadernos e tablets 139 


\section{LISTA DE TABELAS}

Tabela 1 - Professores de escolas urbanas, por uso do computador e da Internet para realizar

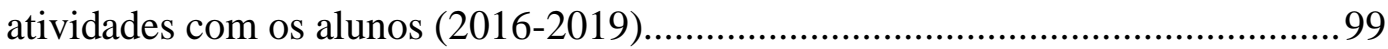




\section{LISTA DE ABREVIATURAS E SIGLAS}

BDTD Biblioteca Digital Brasileira de Teses e Dissertações

BNCC Base Nacional Comum Curricular

CAPES Coordenação de Aperfeiçoamento de Pessoal de Nível Superior

CENPEC Centro de Estudos e Pesquisas em Educação, Cultura e Ação Comunitária

Cetic.br Centro Regional de Estudos para o Desenvolvimento da Sociedade da Informação

Consed Conselho Nacional de Secretários de Educação

CPG Convivência Positiva em Grupo

DCN Diretrizes Curriculares Nacionais

Enem Exame Nacional do Ensino Médio

FAPESP $\quad$ Fundação de Amparo à Pesquisa do Estado de São Paulo

FEUSP $\quad$ Faculdade de Educação da Universidade de São Paulo

IBICT Instituto Brasileiro de Informação em Ciência e Tecnologia

IC Iniciação Científica

Inep Instituto Nacional de Estudos e Pesquisas Educacionais Anísio Teixeira

LGPD Lei Geral de Proteção de Dados

LMD Laboratório Multidisciplinar

MEC Ministério da Educação

POIE Professor Orientador de Informática Educativa

PROUCA Programa Um Computador por Aluno

PRPG USP Pró-reitoria de Pós-graduação da USP

RNP Rede Nacional de Pesquisa e Ensino

TDIC Tecnologias Digitais da Informação e Comunicação

TIC Tecnologias da Informação e Comunicação

Undime União Nacional dos Dirigentes Municipais de Educação

Unesco Organização das Nações Unidas para a Educação, a Ciência e a Cultura 


\section{SUMÁRIO}

APRESENTAÇÃO...................................................................................................18

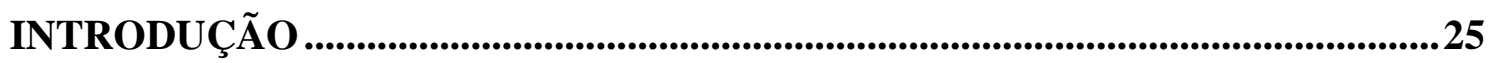

1 CADERNOS ANALÓgICOS E DIGITAIS: INOVAÇÃO E MUDANÇA NA CULTURA ESCOLAR...............................................................................................31

2 DOS MODOS DA PRODUÇÃO DA PESQUISA .........................................................37

2.1 DIÁLOGOS COM O CAMPO EDUCACIONAL: ESTUDOS REALIZADOS E AS CONTRIBUIÇÕES DA PESQUISA DESENVOLVIDA ………………………….....

2.2 DAS FONTES DOCUMENTAIS E DO CAMINHO PARA A PESQUISA DE CAMPO . .46

2.3 A INSTITUIÇÃO PESQUISADA E SUAS RELAÇÕES COM A TECNOLOGIA.....50

2.4 DOS SUJEITOS DA PESQUISA E DAS OBSERVAÇÕES DE SITUAÇÕES DIDÁTICAS: DOIS CENÁRIOS....................................................................................

2.5 SUPORTES DE ESCRITA ESCOLARES NO FOCO: DIMENSÕES ANALISADAS .57

2.1.1 Espaço ....................................................................................................................................59

2.1.2 Tempo ….............................................................................................................60

2.1.3 Projeto político pedagógico....................................................................................................63

2.1.4 Professor ............................................................................................................64

2.1.5 Área do conhecimento .......................................................................................................65

2.1.6 Objeto do conhecimento.......................................................................................................66

2.1.7 Contexto..........................................................................................................................................66

2.1.8 Aluno.....................................................................................................................................67

3 TRADIÇÕES E IMPERATIVOS DE MUDANÇAS: COMO OS SUPORTES DE ESCRITA SE CONSTITUEM NAS ESCOLAS .............................................................70

3.1 TECNOLOGIAS DIGITAIS NA EDUCAÇÃO: ENTRE OS DOCUMENTOS

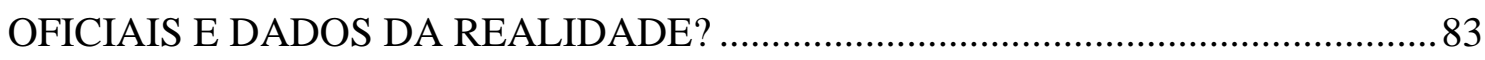

3.1.1 Dados gerais de acesso às tecnologias digitais....................................................................87

3.1.2 Dados sobre práticas docentes...........................................................................................94

4 MODOS DE REGISTRO EM DOIS CENÁRIOS: ENTRE OS CONDICIONAMENTOS DOCENTES E A EXPRESSÃO DE IDENTIDADES 103

5 MODOS DE REGISTRO E FORMAS DE APRENDER: RELAÇÕES E SENTIDOS. 
CONSIDERAÇÕES FINAIS .144

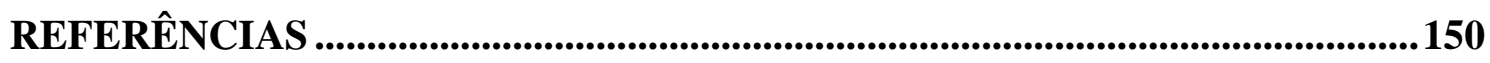

APÊNDICE A - ENTREVISTA COM TOMÁS.....................................................15959

APÊNDICE B - ENTREVISTA COM JULIA ........................................................1622

APÊNDICE C - ENTREVISTA COM GABRIELA...............................................1644

APÊNDICE D - ENTREVISTA COM VALENTINA .............................................1688

APÊNDICE E - ENTREVISTA COM ROBERTA................................................1711

APÊNDICE F - ENTREVISTA COM LORENA ...................................................1744 


\title{
APRESENTAÇÃO
}

\author{
Nosso verbo ser \\ É uma identidade \\ Mas sem projeto \\ $E$ se temos verbo \\ Com objeto \\ É bem mais direto \\ No entanto falta \\ Ter um sujeito \\ Pra ter afeto \\ Mas se é um sujeito \\ Que se sujeita \\ Ainda é objeto. \\ (José Miguel Wisnik)
}

Estamos tão habituados a encontrar cadernos entre os itens das listas de materiais escolares que não paramos para pensar como sua história, sua constituição como um objeto dessa natureza e seus usos se entrecruzam com a história da educação. É como se esse material passasse despercebido e sem qualquer questionamento ou estranhamento, ainda que inserido em um mundo cada vez mais digital, online e com instituições escolares com tablets como artefatos também incluídos nessas listas. Ou seja, tal objeto é desconsiderado como um importante para se conhecer mais e melhor a escola, a cultura escolar e a material, o projeto pedagógico da instituição, os professores, os alunos, o currículo, as práticas avaliativas, os tempos e as relações que permeiam todos esses elementos.

Durante a minha graduação em Pedagogia pela Faculdade de Educação da Universidade de São Paulo (FEUSP), as questões contemporâneas relacionadas à cultura escolar, em especial, à cultura material me instigaram a pesquisar e me aproximar mais desse tema. De junho de 2013 a maio de 2014, realizei um trabalho de Iniciação Científica (IC) financiada pela Fundação de Amparo à Pesquisa do Estado de São Paulo (FAPESP), sob a orientação da Professora Doutora Rita de Cassia Gallego, intitulada Quais os sentidos dos cadernos segundo os alunos? Um estudo acerca dos cadernos de alunos do nono ano do Ensino Fundamental, que culminou no relatório final Um objeto, vários sentidos. A pesquisa teve como principal objetivo investigar a função, os sentidos, a importância e a influência dos cadernos escolares na trajetória de alunos que estudaram no contexto da Progressão Continuada de escolas estaduais de São Paulo e que cursavam o último ano do Ensino Fundamental II. Os dados foram coletados com alunos de uma escola pública da zona leste da cidade de São Paulo. Apesar de aqueles estudantes serem nativos digitais, ou seja, já terem nascido inseridos na cultura digital, não era consenso entre 
eles que as tecnologias digitais substituíssem, parcial ou totalmente, a função e o(s) uso(s) dos cadernos.

Ficou evidente, naquele trabalho, que os cadernos têm seus usos, funções e sentidos relacionados com grandes concepções da educação: a aprendizagem, o ensino e o conhecimento. Durante o estudo, pôde-se verificar que não há apenas uma função, um sentido, um motivo de importância dos cadernos na trajetória escolar dos alunos, sendo, portanto, um objeto com múltiplos sentidos. Em outras palavras, o caderno é o mesmo fisicamente, mas, em seu conteúdo, há inúmeras diferenças e possibilidades que dependem da disciplina, da relação que os alunos têm com os professores, das práticas pedagógicas e do universo particular de cada sujeito. Contudo, um aspecto recorrente apontado pelos alunos era o não uso das tecnologias. Eles afirmavam constantemente que não podiam usar o celular para fazerem suas anotações, assim como não utilizavam o laboratório de informática nenhuma vez ao longo do ano. Assim, o uso dos computadores ficava restrito a poucas pesquisas que deveriam ser realizadas em casa.

Naquela ocasião, em uma conversa coletiva com os estudantes, quando se perguntara se fazia sentido usar os cadernos e se esse era um material importante, uma das alunas da turma afirmou rapidamente que sim; porém, disse que poderiam ser usados tablets ao invés de cadernos. O apelo pelas tecnologias digitais se devia, sobretudo, à frequente reclamação de todos os alunos no tocante ao peso das mochilas, já que eles tinham que levar o livro, a apostila e o caderno para cada uma das seis disciplinas das quais tinham aula no dia. Dessa forma, os estudantes diziam que, com o uso das tecnologias, o volume de material a ser carregado diminuiria. Outro ponto levantado pelos alunos em favor do uso da tecnologia era o ambiental, uma vez que, com o uso dos aparelhos, economizar-se-ia papel.

Além disso, mais um aspecto a favor do uso de tablets foi mencionado, a saber, a possibilidade de guardar os registros de anos anteriores, não limitando os alunos às anotações exclusivas daquele caderno. Quando perguntado se usavam as tecnologias digitais na escola, uma das alunas prontamente disse que, desde a quinta série, eles nunca mais tinham ido ao laboratório de informática da escola e que nenhum professor tinha a iniciativa de pedir atividades que requeressem o uso do computador ou do celular naquela instituição. Relativamente ao uso do computador em casa para a realização de atividades, vários estudantes mencionaram que os docentes solicitavam pesquisa como lição de casa ou trabalho avaliativo.

Também, durante conversas individuais com os alunos sujeitos do referido estudo, quando questionados se o caderno era um material importante, todos afirmaram que sim, tendo alguns deles mencionado que não conseguiam imaginar o caderno fora da lista de materiais escolares. Um dos estudantes apontou, porém, que os cadernos poderiam ser substituídos por 
tablets, pois são mais modernos e avançados. Em contrapartida, outro aluno considerava que substituir os cadernos por determinado recurso tecnológico era ruim, já que o instrumento poderia apresentar algum tipo de problema, e seria prejudicial ficar sem o aparelho que teria assumido a função dos cadernos por algum tempo.

O final dessa pesquisa coincidiu com a minha entrada como estagiária dos anos finais de Ensino Fundamental I em uma escola particular na zona sul de São Paulo, onde os computadores se faziam presentes nas salas de aula. Nessa instituição, cada sala possuía um notebook, alto-falantes, projetor e telão para uso dos professores, além de diversos kits de chromebooks ${ }^{1}$ espalhados por todo o prédio para empréstimo dos alunos. Diferentemente da escola em que foi realizada a coleta de dados da pesquisa de Iniciação Científica, nessa, professores utilizavam cotidianamente os computadores em suas aulas, valendo-se de vídeos, imagens e músicas, apresentações em Power Point, correções coletivas feitas em Word e projetadas na lousa, otimizando seus tempos. Era comum, embora não diário, que os alunos também utilizassem esses equipamentos nos momentos de aula, acessando jogos online relacionados com os conteúdos estudados, fazendo pesquisas na internet dentro da sala de aula, montando e realizando de apresentação de trabalhos, elaborando textos, entre outros. Desse modo, passou a fazer parte da minha rotina lidar com crianças de quartos e quintos anos bastante apropriadas do trabalho com os computadores. Contudo, era recorrente ouvir alunos falando sobre a expectativa de chegarem ao Ensino Fundamental II, para que o uso dos celulares na escola fosse autorizado, ou, ainda, vê-los fascinados com uma escola vizinha que atende alunos a partir do Ensino Fundamental II, cujos tablets eram materiais obrigatórios, afirmando que esse era um dos motivos pelos quais iriam e/ou gostariam de mudar de escola.

Assim, fui percebendo o apelo cada vez maior dos alunos pelas tecnologias digitais, visto que, na primeira instituição, aquela em que realizei a pesquisa de IC, elas eram quase que completamente ignoradas, por mais que grande parte dos alunos de nono ano se incomodasse e cobrasse que elas fossem incorporadas às aulas. Já na outra escola, com a qual eu tinha vínculo de estagiária, apesar de os professores usarem diariamente, e haver algumas inserções de usos pelos alunos, isso não bastava, pois estes esperavam pelo uso do próprio aparelho ou tinham a expectativa de mudar de escola, transferindo-se para a instituição que tinha o tablet como material individual e obrigatório.

Diante desse contexto, também novo para mim, em que crianças poderiam ter um tablet de uso individual, eu me questionava: que suporte é esse? Quando a escola lança mão desse

\footnotetext{
${ }^{1}$ Chromebooks são um tipo de computador, cuja finalidade é realizar atividades do dia a dia com praticidade. Esses computadores tendem a ser menores, mais leves, simples, mas também mais fracos do que um notebook.
} 
suporte de escrita, qual é o lugar do caderno de papel costurado ou espiralado? É possível conciliar esses dois materiais ou seus usos são excludentes? Será que os alunos que utilizam os tablets, de fato, preferem esse material? Como os estudantes incorporam essa ferramenta em sua rotina de aulas e estudos?

Além disso, da época em que se realizou a pesquisa de IC para cá, as tecnologias digitais estiveram cada vez mais presentes na vida de todos, por meio de smartphones, por exemplo, mais populares e acessíveis. Vale ressaltar também que grande parte das crianças tem contato primeiro com as telas, quando ainda são bebês, e, mais tarde, com os cadernos. A partir desse contexto, novas questões se impuseram, como: qual é a função dos cadernos escolares para os alunos? Como os cadernos têm sido integrados num contexto de formação que, em tese, sofreu uma reestruturação pedagógica? Há benefícios, de acordo com os alunos, que só existem com o uso das tecnologias?

Diante de tantos questionamentos e problemáticas, e com o objetivo de investigar se quando as tecnologias digitais estão inseridas na escola, essas apenas substituem o uso dos cadernos, ou se acrescentam inovações e potencialidades a esse suporte de escrita, fez-se um estudo de campo em uma escola particular ${ }^{2}$ da zona sul de São Paulo, que usa de maneira expressiva as tecnologias digitais. Nessa mesma instituição, os alunos da escola em que estagiei ficavam encantados pelos tablets fazerem parte dos materiais obrigatórios para os estudantes. Então, neste estudo, acompanhou-se a rotina escolar, especialmente as aulas de Língua Portuguesa, de alunos de sextos e sétimos anos por quase um semestre em 2019.

Em razão de a pandemia do Coronavírus ter acometido o mundo no início de 2020, impondo o distanciamento social, o fechamento das escolas e, por conseguinte, o ensino remoto, a investigação da pesquisa precisou tomar novos rumos, com os quais vieram outras questões que não poderiam ser ignoradas: em que momento dessa escola online, das aulas digitais é utilizado o caderno de papel? Qual suporte de escrita se usa agora? De que forma? Com qual propósito? Como as práticas escolares de até então reverberam no modelo de educação remota? Quais os impactos desse novo modelo na maneira de se organizar e desenvolver suas atividades? Quais formas de registro foram incorporadas devido à nova forma de ensinar e aprender impulsionada pela pandemia? Como essas formas de registros se sobrepõem? O que os estudantes faziam antes e impacta no que se faz nesse novo contexto? De que maneira?

A pesquisa desenvolvida não teve como intuito buscar evidências para comprovar os benefícios das tecnologias digitais na escola, tampouco trazer axiomas ou ter a pretensão de

\footnotetext{
${ }^{2}$ Por questões éticas, o nome da escola não será revelado.
} 
mostrar a verdade sobre o uso dessas tecnologias como suportes de escrita. A intenção consistiu em investigar uma potencialidade que pode se tornar efetiva ou não, em função de uma série complexa de fatores. À parte isso, é preciso considerar que todo o estudo foi realizado em uma instituição que tem o tablet como um dos seus materiais escolares obrigatórios desde 2014, ou seja, muito antes da pandemia. Tal fato implica em uma escola com alunos e professores que, em primeiro lugar, têm acesso as tecnologias, pertencem a uma classe social e econômica mais favorecida, com muito mais contato e domínio dessas ferramentas, com maior poder de organização nesse novo cenário remoto. Embora se considere que este estudo foi realizado num contexto privilegiado, acredita-se que as análises e reflexões suscitadas podem auxiliar e contribuir para se pensar nas tecnologias digitais como suportes de escrita na educação de maneira mais ampla.

Levando tais considerações em conta e contemplando um momento de nossa história, especialmente da instituição escolar, tão significativo, o presente trabalho pretende, portanto, contribuir com os estudos da área de História da Educação, particularmente com as pesquisas acerca da cultura escolar. Isso porque toma os cadernos como objetos da cultura material da escola, mostrando que os suportes de escrita - sejam eles físicos ou online, analógicos ou digitais, de papel ou em telas - não têm seus usos caracterizados como sendo de forma alguma naturais, singulares ou óbvios; estabelecem-se como produto e, ao mesmo tempo, como produtores de um processo de construção com mudanças significativas em diversos momentos.

O que se pretende nesta pesquisa é justamente, como José Miguel Wisnik escreve e está na epígrafe, encontrar os sujeitos dos objetos. Isto é, procura-se a todo instante tratar dos suportes de escrita em relação aos sujeitos que os utilizam. Mais do que pensar no material pelo material, o que já seria de grande valia, trata-se de pensar no objeto em suas relações diversas. Além disso, esta dissertação oferece contribuições para a área de Currículo e Práticas Pedagógicas, uma vez que, partindo do objeto cadernos escolares, trata-se das relações entre ensino, aprendizagem e cultura material, evocando diversas temáticas didáticas, como os processos de construção do conhecimento em sala de aula, o uso de materiais e a inserção das tecnologias nas escolas.

No que diz respeito ao caminho percorrido na realização desta dissertação, segue-se, em caráter introdutório, considerações acerca do objeto de estudo deste trabalho, contextualizandoo de modo a delimitar as questões da pesquisa. A dissertação foi dividida em cinco capítulos, dedicando-se o primeiro, intitulado Cadernos analógicos e digitais: inovação e mudança na cultura escolar, a debater os conceitos de inovação, mudança e reforma educacionais, levando 
em conta os cadernos de papel e a inserção das tecnologias digitais nesse contexto e como eles estão relacionados com a cultura escolar.

Em seguida, o capítulo Dos modos da produção da pesquisa é subdividido em cinco partes. Na primeira, apresenta-se o levantamento bibliográfico realizado, apontando as lacunas e contribuições deste trabalho. A segunda se dedica a expor as fontes documentais utilizadas e o caminho percorrido até se chegar na instituição em que a pesquisa de campo pôde ser desenvolvida, a debater os conceitos de inovação, mudança e reforma educacionais, levando em conta os cadernos de papel e a inserção das tecnologias digitais nesse contexto. Já a terceira apresenta a instituição em que a pesquisa foi realizada e as suas relações com as tecnologias digitais. Na quarta parte, apresenta-se os sujeitos da pesquisa e situa-se os contextos do campo. Por fim, a quinta parte lança luz nos suportes de escrita, colocando-os em diálogo com as dimensões envolvidas nas possibilidades de escolhas desses objetos e nos usos que se faz deles dentro das escolas, os quais compõem uma complexa trama tecida por diversos aspectos da cultura escolar.

O capítulo Tradições e imperativos de mudanças: como os suportes de escrita se constituem nas escolas destina-se a elucidar os cadernos como parte da cultura material das escolas e, portanto, da cultura escolar, tendo sua trajetória marcada por rupturas, permanências e ressignificações. Além disso, esse capítulo possui uma subdivisão que trata de como a presença e o uso das tecnologias digitais nas escolas estão previstos em três documentos oficiais, como as Diretrizes Curriculares Nacionais (DCN), a Base Nacional Comum Curricular (BNCC) e o Currículo da cidade de São Paulo. Afora isso, também se analisa dados da realidade sobre o acesso e as práticas docentes, levando em consideração as tecnologias digitais inseridas no nosso país, com relação à educação e às instituições de ensino. Esses dados são importantes, porque, além de confrontar o que está expresso no plano normativo com o que se tem na realidade, eles permitem situar a instituição em que a pesquisa foi desenvolvida e as práticas pedagógicas encontradas.

O capítulo Modos de registro em dois cenários: entre os condicionamentos docentes e a expressão de identidades apresenta parte da discussão e da análise dos dados, propondo-se a analisar, para além da escolha dos suportes de escrita pelos alunos, a maneira como são utilizados efetivamente, com o objetivo de investigar se, quando há a opção pelos cadernos digitais, há inovações e potencialidades consideradas pelos alunos e professores, ou se o uso é muito próximo ao que se faz do caderno analógico.

Já em Modos de registro e formas de aprender: relações e sentidos, aborda-se a relação entre os suportes de escrita e a aprendizagem dos alunos, considerando seus modos pessoais de 
apropriação do conhecimento. Além disso, analisa-se as funções que os estudantes atribuem aos seus registros e seus impactos na relação com os conhecimentos e a importância que os alunos conferem aos seus cadernos e tablets, bem como a função que esses artefatos assumem para cada um dos estudantes ouvidos nesta pesquisa.

Por último, as considerações finais respondem às questões levantadas nesta apresentação e delineiam os principais aspectos da pesquisa, compreendendo se quando estão inseridas na escola, as tecnologias digitais apenas substituem o uso dos cadernos, ou se acrescentam inovações e potencialidades a esse suporte de escrita, ou ainda se têm seus usos concomitantes. Após as referências utilizadas, pode-se encontrar, nos apêndices do trabalho, as transcrições das entrevistas feitas. 


\section{INTRODUÇÃO}

O objeto de estudo desta dissertação são os cadernos escolares frente à presença das tecnologias digitais dentro das instituições de ensino. Fez-se uma pesquisa de campo, durante o segundo semestre de 2019, em uma renomada escola da zona sul da cidade de São Paulo, amplamente reconhecida pelo ensino de excelência e a forte presença das tecnologias dentro das salas de aula, solicitando inclusive, um tablet para uso individual dos estudantes. O objetivo foi investigar se, quando estão inseridas na escola, as ferramentas digitais apenas substituem o uso dos cadernos ou se acrescentam inovações e potencialidades a esse suporte de escrita, ou ainda se têm usos concomitantes aos cadernos analógicos. Nela, aproximou-se da rotina escolar, por meio do acompanhamento das aulas de três professoras de Língua Portuguesa de sextos e sétimos anos e da leitura de diversos documentos e publicações da escola.

No entanto, no início do ano 2020, o mundo foi acometido pela pandemia do novo Coronavírus que acabou impondo o distanciamento social, o fechamento das escolas e, por conseguinte, o ensino remoto. Todo esse contexto em meio a coleta de dados impeliu a pesquisa a também averiguar em que momentos os estudantes utilizam cadernos de papel em um período de aulas virtuais, quando a escola está completamente online. Essa parte da pesquisa aconteceu a partir de conversas informais com uma das professoras de Língua Portuguesa (acompanhada anteriormente), e teve como fontes nucleares entrevistas virtuais com seis alunos de sétimos anos (sendo cinco meninas e um menino; em 2019, estavam todos nas turmas de sextos anos acompanhadas durante parte do período de coleta de dados) e fotografias dos cadernos analógicos e digitais desses estudantes. Todo esse material foi analisado e categorizado com base na perspectiva dos estudos da cultura escolar (Frago, Julia e Escolano), levando em consideração as contribuições sobre os cadernos de Frago, Mignot, Gvirtz e Santos, articuladas aos estudos de Coll, Monereo, Kenski e Moran sobre as tecnologias digitais nas escolas.

Compreende-se que cadernos são materiais privilegiados para observar processos históricos e pedagógicos da vida cotidiana escolar, uma vez que reúnem duas condições singulares: a primeira é a capacidade de conservar o registro, distinguindo-os de outros espaços de escrita, de modo que esses artefatos podem ser guardados, colecionados, revisados e revisitados ao longo do tempo. A segunda é que eles se constituem em espaços de interação diversas, entre alunos e alunos, alunos e professores, alunos e conhecimento. Portanto, pode-se vislumbrar, neles, a tarefa escolar.

A história das pesquisas tendo como fonte e/ou objeto de estudo os cadernos escolares se entrecruza com a História Cultural (BURKE, 2005; CHARTIER, 1988). Esse campo 
historiográfico se tornou mais fecundo nos últimos anos do século $\mathrm{XX}$, quando passou a se interessar não só por objetos de estudos historiográficos, como também pelos sujeitos, que são produtores e receptores de cultura, e pelas práticas. Peter Burke (2005) aponta que, nas últimas décadas, os Estudos Culturais (re)despertaram a atenção de pesquisadores em diversos países. Desse modo, historiadores que privilegiavam temáticas sociais e econômicas passaram a dar maior atenção às questões culturais.

Outrossim, os cadernos, que durante muito tempo passavam despercebidos aos olhos dos pesquisadores por serem um material escolar tão naturalizado, foram sendo reconhecidos como uma fonte rica de pesquisa. Isso porque, por meio deles, é possível ter acesso a conceitos que se têm de educação, infância e escola, além de saber sobre os alunos, os professores, o currículo, os processos de avaliação, os valores e os costumes. Por tudo isso, especialmente nos últimos trinta anos, historiadores da educação, pesquisadores sobre currículo, avaliação e formação de professores, bem como psicólogos e outros profissionais com interesse em estudar o que é vivido dentro das instituições escolares e o que acontece no interior da sala de aula tomaram os cadernos escolares como um importante objeto e fonte de pesquisas.

Tradicionalmente, os cadernos eram usados pelos alunos da mesma maneira e ao mesmo tempo, com a finalidade de resolver exercícios e atividades e copiar da lousa (VIÑAO, 2008). Em sua maioria, os registros da aula não tinham muitas diferenças entre um aluno e outro, serviam para estudar para as provas, posto que eram verificados pelos professores e cobrados nas avaliações. Assim, o caderno e os registros feitos pelos alunos, eram, costumeiramente, uma garantia ao professor de que ali havia uma relação ensinar-aprender. Contudo, no final da década de 1990, novas propostas pedagógicas procuraram rever toda a configuração da educação, inclusive o método simultâneo ${ }^{3}$ e as aulas majoritariamente expositivas. Ademais, outra alteração relevante aconteceu em 2006, quando foi determinado o aumento de um ano na etapa do Ensino Fundamental por meio da lei federal no 11.274/2006 (BRASIL, 2006).

Todas essas mudanças ocorridas nas últimas três décadas alteraram também a organização escolar, já que houve modificações, conforme salienta Gallego (2011), nos tempos e maneiras de ensinar e aprender, assim como na forma de avaliar estes processos que romperam

\footnotetext{
${ }^{3}$ O método simultâneo ganhou força nos fins do século XVII com Jean-Baptiste de La Salle (1651-1719), fundador do Instituto dos Irmãos das Escolas Cristãs, na França, em substituição ao método individual, praticado até então. De acordo com Gallego (2011, p. 120), "seus esforços incidiam na uniformização do contexto de aprendizagem mediante a classificação, a fragmentação dos elementos em jogo, a saber: alunos, saberes, classe (espaço)" . Isso implicava em o professor organizar as matérias de modo a fixar anteriormente as matérias a serem ensinadas (organizadas de maneira hierárquica, sustentadas em várias etapas, apoiadas em manuais) e seu tempo. Assim, nesse método, o professor dividia seus alunos em um certo número de classes de acordo com seus níveis de conhecimento e instruía simultaneamente todos os alunos de uma mesma classe. Uma análise mais acurada dessas questões é realizada por Gallego (2008).
} 
ou ressignificaram práticas tradicionalmente presentes na cultura escolar enraizadas há cerca de 100 anos com a constituição das escolas de massas no fim do século XIX.

Somada a todas essas mudanças, destaca-se o contexto digital, que cada vez está mais presente na vida das pessoas e das escolas, demandando uma série de inovações, visto que as crianças estão em contato com diferentes tecnologias desde muito cedo, em especial a internet. A hipótese é que tal contexto tem modificado a maneira como elas aprendem, posto que, como já afirmava Kenski (2003, p. 5), as tecnologias proporcionam "processos intensivos de interação, de integração e mesmo a imersão total do aprendiz em um ambiente de realidade virtual". Ou seja, as tecnologias ampliam a possibilidade da aprendizagem como um processo mais coletivo e integrado, articulando pessoas e informações de diferentes lugares e circunstâncias.

Além disso, considera-se que, no contexto das Tecnologias Digitais da Informação e Comunicação (TDIC), não existe um ponto de chegada para os conhecimentos. Ao contrário, há o favorecimento de um constante e dinâmico processo de interações, colocando as pessoas em "estado de permanentes aprendizagens" (KENSKI, 2003, p. 7). Também, como a autora assinala,

esse movimento constante leva-nos à redefinição do processo de aquisição de
conhecimentos, caracterizados como saberes personalizados, flexíveis e
articulados em permanente construção individual e social. As aprendizagens,
por sua vez, ao invés de se constituírem como um corpo sólido de
conhecimentos determinados previamente e historicamente datados,
constituem-se como aprendizagens abertas, não lineares e mutáveis.
Aprendizagens descartáveis, seletivas, múltiplas e em permanente
atualização. (p. 7).

Dessarte, a autora aponta para a necessidade de se repensar os modos de ensino e aprendizagem, uma vez que há novas possibilidades e formatos de acesso à informação, integração e comunicação, indicando, assim, implicações da presença das tecnologias digitais na educação, facultadas pelos computadores. É como se a sociedade estivesse em um novo estágio de desenvolvimento da sociedade e, nele, são requeridos novos valores, comportamentos e atitudes (KENSKI, 2003).

Vale lembrar que, na década de 1990, o sonho de toda escola era ter um laboratório de informática. Em algumas instituições, CDs e, posteriormente, DVDs foram muito utilizados durante as aulas, disso resultando uma mudança de olhar diante dessas tecnologias. Entretanto, o grande marco divisor de águas surge com a internet, pois ela oferece a possibilidade de haver uma interação e conexão maior entre as pessoas. 
Em 2020, completou-se 25 anos da abertura comercial da internet no Brasil. Isso significa que, nas escolas de Educação Básica, já temos crianças nativas digitais ou crianças informatizadas, visto que quando essas crianças nasceram, essa tecnologia já estava instalada na sociedade. Vale ressaltar que presenciar a chegada de uma nova tecnologia não é o mesmo que nascer com ela já implantada. Além disso, como alerta Ferreiro (2013), essa tecnologia já estava instalada e visível nas casas de alguns, embora não necessariamente à sua disposição, e para outros, tratava-se de um objeto de desejo ainda fora do alcance. Como afirma a pesquisadora, o verbo comunicar tem outros sentidos para essa nova geração, significa telefonar, usar o chat, trocar mensagens. Em suas palavras, “o verbo comunicar já não remete, de maneira espontânea, à escrita sobre papel.” (FERREIRO, 2013, p. 447).

Nesse ponto, considera-se relevante definir e conceituar o que este trabalho entende por tecnologia. De acordo com o dicionário Houaiss (2008, p. 179), o termo tecnologia significa "conjunto dos conhecimentos científicos, dos processos e métodos na criação e utilização de bens e serviços"; também exprime "técnica ou conjunto de técnicas de um domínio particular", ou ainda "aquela que se utiliza de técnicas de última geração". Quando pensamos sobre esse termo, é comum vir à mente os mais recentes aparatos digitais ou eletrônicos, a exemplo de celulares de última geração, impressoras 3D, drones, assistentes virtuais ou televisões ultrafinas e com alta resolução. Contudo, não se pode limitar tecnologia a esses dispositivos, pois como afirma Kenski (2012, p. 22-23), “[...] a expressão ‘tecnologia’ diz respeito a muitas outras coisas além de máquinas. $\mathrm{O}$ conceito de tecnologias engloba a totalidade de coisas que a engenhosidade do cérebro humano conseguiu criar em todas as épocas, suas formas de uso, suas aplicações". A autora assinala ainda que "as tecnologias são tão antigas quanto a espécie humana" (p. 15). Assim, lousas, lápis, canetas, mesas e o próprio objeto desta pesquisa, os cadernos, são tecnologias que fazem parte da instituição escolar.

Por outro lado, tecnologia digital possui um sentido mais restrito, limitando-se àquelas tecnologias com base telemática, ou seja, aquelas que são baseadas na informática e nas telecomunicações. É preciso diferenciar, portanto, tecnologia de tecnologia digital. Kenski (2012) destaca a grande influência que as tecnologias digitais exercem na organização da sociedade:

$\mathrm{Na}$ atualidade, o surgimento de um novo tipo de sociedade tecnológica é determinado principalmente pelos avanços das tecnologias digitais de comunicação e informação e pela microeletrônica. Essas novas tecnologias - assim consideradas em relação às tecnologias anteriormente existentes -, quando disseminadas socialmente, alteram as qualificações profissionais e a maneira como as pessoas vivem cotidianamente, trabalham, informam-se e se comunicam com outras pessoas e com todo o mundo. (p. 22). 
Impactada pela tecnologia digital, a mudança foi rápida em comparação com outras tecnologias da comunicação, pois, como afirma Ferreiro (2013), o rádio levou 38 anos para ter 50 milhões de usuários, a televisão demorou 13 anos para alcançar esse mesmo número de adeptos e o computador levou 16 anos, enquanto a internet alcançou esse número de usuários em apenas quatro anos.

As tecnologias digitais abrem uma importante possibilidade de comunicação e colaboração, que, na sociedade em geral, é vista nas redes sociais e no compartilhamento de vivências. Essa conexão pode reverberar positivamente na educação, dado que, de acordo com Moran (2018), tais tecnologias oportunizam a troca de informações entre estudantes, a participação de atividades em grupo, o envolvimento na resolução de projetos, proporcionando a horizontalização da educação, expressada em múltiplas e diversas interações.

Conforme Almeida e Valente (2012, p. 60) apontam, as tecnologias digitais de informação e comunicação

propiciam a reconfiguração da prática pedagógica, a abertura e plasticidade do currículo e o exercício da coautoria de professores e alunos. Por meio da midiatização das TDIC, o desenvolvimento do currículo se expande para além das fronteiras espaços-temporais da sala de aula e das instituições educativas; supera a prescrição de conteúdos apresentados em livros, portais e outros materiais; estabelece ligações com os diferentes espaços do saber e acontecimentos do cotidiano; e torna públicas as experiências, os valores e os conhecimentos, antes restritos ao grupo presente nos espaços físicos, onde se realizava $\mathrm{o}$ ato pedagógico.

Nesse mesmo sentido, Almeida (2018) ressalta que é justamente pela diversidade de linguagens e pela multiplicidade de tecnologias para aprender, criar, interagir e estabelecer relações, que a convergência entre os espaços presenciais e virtuais manifestam novas formas de expressar ideias, pensamentos, desejos, sentimentos e crenças. Assim, além de todas essas mudanças transformarem como vivemos e comunicamos, suscitam participação e colaboração, emergindo, assim, uma cultura digital. Esta, por sua vez, refere-se à "cultura decorrente dos usos da internet e outros aparatos digitais que intermedeiam as relações e as produções humanas, favorecendo trocas e interações entre as pessoas e novos modelos de aprendizagem e meios de expressão.” (ALTENFELDER et al., 2011, p. 10).

Pode-se constatar, então, que todo esse contexto já requeria que se repensassem a organização escolar e as formas de ensinar e aprender. Porém, com a pandemia do Coronavírus que impôs o distanciamento social e o fechamento das escolas, impera uma urgência jamais vista. Esse contexto traz uma nova realidade que revela e acelera a história e a necessidade de mudanças. Como Moran já destacava em 2000, ensinar e aprender com tecnologias digitais era um desafio que, até então, não havia sido enfrentado com profundidade necessária. O ensino 
remoto, contudo, compele esse enfrentamento com mais seriedade e vigor, escancarando a controversa relação da escola com as tecnologias digitais.

Logo, por tratar de uma problemática extremamente atual, visto que se investigou os cadernos de papel e os tablets, ou seja, suportes de escrita analógicos e digitais em pleno ensino remoto, a pesquisa realizada mostra-se relevante. Ademais, essa importante lacuna acerca das implicações das tecnologias para uso dos cadernos escolares já havia sido identificada em crianças do Ensino Fundamental. 


\section{CADERNOS ANALÓGICOS E DIGITAIS: INOVAÇÃO E MUDANÇA NA CULTURA ESCOLAR}

Este capítulo propõe-se a debater os conceitos de inovação, mudança e reforma educacionais, distinguindo-os com a intenção de esclarecer se a entrada das tecnologias digitais na educação representa, efetivamente, uma alteração nas práticas pedagógicas. É comum conceber o uso das tecnologias digitais nas escolas como sinônimo da presença de práticas inovadoras, de algo atraente para os alunos, que acarreta ganhos pedagógicos, os quais rompem com o ensino tradicional, apresentando e ensinando aquilo que há de melhor e mais moderno. Entretanto, será que se pode concordar com essa visão? A mera presença da tecnologia altera por si só a relação pedagógica? E mais, não ter cadernos como suporte de escrita implica em uma inovação na educação? Em que medida utilizar tablets é, por certo, uma inovação? Como mostra Cordeiro (2002, p. 11), "a mudança em si e, portanto, a produção do novo parece garantir, de antemão, a validade das propostas apresentadas". No entanto, faz-se importante conceituar e distinguir o que é, de fato, inovação educacional, a fim de situar o(s) uso(s) das tecnologias digitais nesse contexto.

O tema inovação está em alta e tem sido tratado por muitos pesquisadores, sendo usado de diversas maneiras por diferentes atores sociais, de inúmeras formas. Na maioria dos casos, o termo evoca mudanças, alterações, o novo, em oposição ao que é tradicional, visto como pejorativo, desqualificado e conservador. Segundo Cordeiro (2002), há duas perspectivas elementares: a primeira, que é mais predominante e costumeira, refere-se a conceber o tradicional como algo negativo, que deve ser combatido e, sem dúvidas, superado; a segunda é mais recente e insinua que há certas virtudes naquilo que é tradicional, no sentido da tradição, e procura, de certa forma, ressalvar aquilo que a educação e o ensino tradicionais tinham ou pudessem ter de bom, útil ou adequado.

Barrera (2016, p. 24), em sua tese, define o termo inovação como "um processo intencional de mudança de uma prática educativa desenvolvida por um sujeito, grupo ou sociedade, que incorpora um ou mais aspectos novos a esta prática.”. Para a referida pesquisadora, essa definição carrega outros aspectos que precisam ser compreendidos: em primeiro lugar, a inovação não é um acontecimento pontual, mas um processo; o segundo ponto importante é que os sujeitos que propõem a inovação têm a intenção de alterar uma prática, limitados a determinado contexto e grupo social; ademais, trata-se de um processo educacional, que não diz respeito apenas à escolarização. Portanto, não se deve associar inovação a melhoria, ou seja, não há carga valorativa. 
Como afirma Ghanem Júnior (2013), geralmente, utilizam-se indistintamente os termos inovação, transformação, mudança e outros com a intenção de nomear os esforços de alteração de práticas educacionais. Esse autor, contudo, acredita que deve haver uma distinção entre eles. Ao contrário, Huberman (1976) trata mudança e inovação como sinônimos, ainda que assinale diferenças de escala e que sejam alterações sempre positivas, visando maximizar a eficiência da educação. Ou seja, na interpretação de Ghanem Júnior (2013), estudos como o de Huberman apresentam que a inovação ou a mudança pode acontecer em uma única escola ou em um pequeno conjunto de instituições, bem como pode abranger toda uma rede escolar de um município, estado, região ou de um país, mencionando tal fenômeno como "reforma educacional".

No entanto, a distinção dos termos elaborada por Ghanem Júnior parece profícua. O pesquisador atribui a expressão "mudança educacional” a uma alteração abrangente, de grande escala, radical, que pode ser chamada de sistêmica. Trata-se de um processo que resulta da convergência de práticas de duas lógicas distintas, a da inovação educacional e a da reforma educacional. Ademais, a mudança educacional depende, segundo o sociólogo, da influência de múltiplos atores, por meio do diálogo fundamentado, da participação democrática e do debate aberto, com diversos e numerosos interesses, saberes, expectativas e contradições, de modo que é impossível de acontecer unilateralmente, impondo-se "de cima para baixo", pela política educacional, pelo ministério da educação ou por meio do sistema escolar (GHANEM JÚNIOR, 2006).

Já a expressão “inovação educacional”, segue outra lógica e tende mais para o que é endógeno, sendo empregada no que diz respeito a práticas locais, não necessariamente inéditas, mas que se diferem daquelas nas quais está inserida. Isso quer dizer que se constituem como práticas de fazeres diferentes. De acordo com Ghanem Júnior (2013, p. 427) são

[...] práticas que se caracterizam pelo isolamento, fragmentação, descontinuidade no tempo, baixa visibilidade das ações e forte voluntarismo de educadores(as). São práticas que se originam na base de sistemas escolares, ou seja, em estabelecimentos individualmente considerados ou em organizações de alcance local, geralmente conhecidas como associações comunitárias. Essencialmente, as práticas de inovação não se caracterizam pelo ineditismo, mas por serem atividades diferentes daquelas que seguem um costume em um determinado lugar e grupo social. São inovadoras em relação a este costume.

Quanto à reforma educacional, essa é utilizada para designar uma terceira lógica diferente, referindo-se a práticas não criadas por pessoas que são agentes diretas de sua execução; práticas que tendem a ser mais exógenas, que são prescritas por autoridades do poder público, e sua sustentabilidade lhe confere permanência, visto que conta com recursos 
orçamentários justamente desse poder. Consoante Ghanem Júnior (2013, p. 427), “o caráter destas práticas é normativo e impositivo, sua abrangência é ampla, seu formato é homogêneo e sua visibilidade é alta.”.

Além da distinção, faz-se necessário apontar que não há progressão de uma lógica para outra, constituindo-se em práticas diferentes que podem, inclusive, estar interligadas. As práticas que se enquadram em uma ou em outra expressão são diferentes, pois têm características distintas e, às vezes, até opostas. É importante sublinhar também que qualquer alteração de prática educacional, seja abarcada pela mudança, inovação ou reforma, não implica em atribuir valor positivo ou negativo. Tais alterações não podem ser consideradas positivas ou negativas em si mesmas, como destaca Ghanem Júnior (2013).

Cordeiro (2002) também assegura distinção entre os termos inovação, mudança e reforma, mas são divergentes das apontadas por Ghanem Júnior. Para o autor, inovações educacionais não são fenômenos corriqueiros aparecendo somente em contextos e condições sociais específicos, sendo que, na maior parte delas, não há uma ruptura brusca, mas aparece como resultado entre tensões das antigas e novas formas ao longo de períodos extensos. De acordo com o referido pesquisador, baseado nas ideias de Popkewitz (1997), o conceito de mudança assume uma perspectiva mais científica que normativa e se relaciona com uma ruptura com o passado e a tradição do presente. Já a reforma concerne à mobilização dos públicos e às relações de poder definidas no espaço público.

Michael Fullan (2009), por sua vez, aponta para a contradição da visão de permanências e mudanças educacionais: enquanto há quem diga que as escolas estão sendo bombardeadas de modificações, há quem pense que não há nada de novo. Do mesmo modo, ouve-se que professores são resistentes a mudanças; em contrapartida, também é comum escutar que administradores introduzem mudanças inesperadas, sem compreender o que ocorre em uma sala de aula.

$\mathrm{O}$ autor não explicita a diferenciação entre os termos. No entanto, assevera que a inovação ocorre em um nível mais simples e é multidimensional, enquanto reforma educacional é algo profundo, que envolve mais do que implementar a última política. Ela implica mudar as culturas de sala de aula, escolas, distritos, universidades, e assim por diante. Nas palavras de Fullan (2009, p. 22, grifo do autor), “[...] a reforma de grande escala diz respeito ao significado compartilhado, indicando que ela envolve simultaneamente a mudança individual e a social.”.

Esse teórico aponta para a dificuldade em realizar uma mudança educacional, posto que existem ao menos três dimensões distintas que envolvem qualquer implementação de novo programa ou política: a primeira tem a ver com o possível uso de materiais novos ou revisados, 
a segunda se refere ao uso possível de novas abordagens de ensino, e a terceira diz sobre a possível alteração de crenças. Conforme o autor, para que haja chance de afetar o resultado é necessário que a mudança deva ocorrer nos três âmbitos. Ainda,

fica claro que qualquer indivíduo pode implementar nenhuma, uma, duas ou todas as três dimensões. Um professor pode usar novos materiais ou tecnologias curriculares, sem alterar a abordagem de ensino, ou pode usar os materiais para alterar alguns comportamentos relacionados com o ensino, mas sem entender as concepções ou crenças subjacentes à mudança. [...] a mudança real envolve mudanças em concepções e comportamentos, que é a razão por que é tão difícil de alcançar. (FULLAN, 2009, p. 39-40, grifo nosso).

Nesse contexto, embora sem considerar as distinções marcadas por Fullan (2009), Cordeiro (2002), tampouco por Ghanem Júnior (2013), Moran (2012) disserta sobre uma resistência quase contraditória às mudanças nas metodologias de aprendizagem. Apesar de se ter iniciativas e avanços, ainda há um apego ao modelo educacional já consolidado. Este autor afirma que estamos em uma fase de transição, não nos situando mais nem no modelo industrial, ainda que se mantenham estruturas organizacionais e mentais, nem no da sociedade do conhecimento, embora algumas das suas expectativas e valores tenham sido incorporados parcialmente. De acordo com Moran (2012, p. 17),

estamos diante de uma tarefa imensa, histórica e que levará décadas: propor, implementar e avaliar novas formas de organizar processos de ensinoaprendizagem, em todos os níveis de ensino, que atendam às complexas necessidades de uma nova sociedade da informação e do conhecimento.”.

Tal difícil tarefa certamente se potencializou no contexto do ensino remoto, uma vez que esse momento de transição que ocorria em determinada velocidade foi impulsionado de modo abrupto pelas necessidades impostas pela educação a distância no contexto pandêmico. O autor assevera que a educação está num constante processo de preservar o passado e, olhando para o presente, preparar o nosso futuro. Ou seja, preserva o passado ao buscar e transmitir referências; olha para o hoje, à medida em que ensina os alunos a compreenderem a si e à sociedade em que vivem, e prepara para o futuro ao antecipar os desafios que virão aos alunos. Além disso, Moran (2012, p. 16) afirma que a organização escolar é prudente e pesada. Em suas palavras,

prudente, para não embarcar em qualquer aventura, porque precisa preservar o passado, olhar para o presente e preparar para o futuro. Prudente, porque tem de encontrar denominadores comuns mínimos compatíveis com as diferenças e desigualdades nacionais e regionais. É pesada, porque burocratizou tanto toda a gestão em todos os níveis que, mesmo aumentando as ações de capacitação, parece que nada muda. Há uma sensação de desperdício de recursos, de não sair do lugar, de experiências pontuais interessantes, mas de extrema lerdeza, de peso cultural imobilizador. 
Ferreiro (2013) explicita que a escola conta com tecnologias próprias que tradicionalmente são conservadas como símbolos pátrios, como é o exemplo da lousa e dos cadernos. Ao mesmo tempo, tem sua trajetória marcada por rejeição a certos aparatos tecnológicos, como foi o caso da caneta esferográfica que: livrava-se do movimento arriscado de ir do tinteiro ao papel por ter a tinta incorporada em seu interior; substituía a ponta afiada às vezes, usada como instrumento de agressão -, por uma ponta arredondada; era rechaçada com a justificativa de que arruinaria a letra dos alunos. Do mesmo modo, combateu o uso das calculadoras, alegando que prejudicariam o cálculo dos estudantes. Igualmente, as máquinas de escrever foram afastadas sob a alegação de serem muito barulhentas. Assim, Ferreiro (2013, p. 458) mostra que a "instituição escolar é altamente conservadora, resistente à incorporação de novas tecnologias que signifiquem uma ruptura radical com práticas anteriores.”. Como a própria autora revela, os impactos da informática vão muito além de a escrita acontecer por meio de um teclado. E acrescenta: "o importante é tudo o que muda ao mesmo tempo: os modos de produção dos textos, sua circulação e a materialidade dos objetos portadores das marcas escritas." (FERREIRO, 2013, p. 450, grifo da autora).

Ademais, o acesso à internet dentro da sala de aula é desafiador. Se, por um lado, os alunos assumem o papel de contribuintes com a aula porque fazem pesquisas e aprofundam questões abordadas pelos professores, por outro, também é possível que eles se distraiam, joguem durante a aula ou se ocupem com as redes sociais. Ou seja, as tecnologias digitais permitem o acesso ao incerto e ao incontrolável do ponto de vista dos professores e, simultaneamente, abrem a possibilidade de os alunos verem, ouvirem, lerem, escreverem, brincarem e transgredirem.

Em uma reflexão sobre a crise na educação, Hannah Arendt (2007) também aponta para a contradição na ação educativa, que permanece conservadora, mas visa a transformação. Isso porque existe uma importância em abrigar e proteger aquilo que foi socialmente construído, no sentido de conservação, ao mesmo tempo em que a escola é o lugar privilegiado para o que é novo e para a criação. Segundo Arendt (2007, p. 242-243, grifo nosso),

parece-me que o conservadorismo, no sentido de conservação, faz parte da essência da atividade educacional, cuja tarefa é sempre abrigar e proteger alguma coisa - a criança contra o mundo, o mundo contra a criança, o novo contra o velho, o velho contra o novo. [...] O mundo é criado por mãos mortais e serve de lar aos mortais durante tempo limitado. O mundo, visto que feito por mortais, se desgasta, e, dado que seus habitantes mudam continuamente, corre o risco de tornar-se mortal como eles. Para preservar o mundo contra a mortalidade de seus criadores e habitantes, ele deve ser, continuamente, posto em ordem. [...] Exatamente em benefício daquilo que é novo e revolucionário em cada criança é que a educação precisa ser conservadora; ela deve preservar essa novidade e introduzi-la como algo 
novo em um mundo velho, que, por mais revolucionário que possa ser em suas ações, é sempre, do ponto de vista da geração seguinte, obsoleto e rente à destruição.

Para a autora, é por meio da apresentação do velho mundo às crianças que lhes é permitido serem capazes de iniciar as mudanças na ordem estabelecida, preservando-se os saberes necessários para a construção e preservação do mundo. De acordo com Barrera (2016), interpretando as ideias de Hannah Arendt, constitui-se em uma tentativa de preservação do próprio mundo e da herança cultural da humanidade, ao mesmo tempo em que há a preparação das futuras gerações, que assumirão diversos papéis em uma sociedade complexa em que suas ações poderão ser incorporadas. A escola foi justamente a solução social criada para garantir tal transmissão. Cabe à escola, portanto, preservar os saberes teóricos e práticos, assegurando que permaneçam operando naquele grupo social, enquanto preparam as crianças e os jovens para assumirem diferentes papéis sociais.

Isso posto, levando em consideração as distinções entre os termos apresentados e conforme perceber-se-á ao longo da discussão dos dados da instituição em que a pesquisa foi realizada (e que serão discutidos nos Capítulos 4 e 5 nesta dissertação), o uso das tecnologias digitais dentro da escola pode ser compreendido tanto como uma inovação quanto como uma mudança. 


\section{DOS MODOS DA PRODUÇÃO DA PESQUISA}

Com o objetivo de investigar os usos e desusos dos cadernos escolares no contexto das tecnologias digitais, de modo a analisar e verificar se quando estão inseridas na escola, apenas substituem o uso do caderno ou acrescentam inovações e oferecem potencialidades, ou ainda se são utilizadas concomitantemente aos cadernos analógicos, realizou-se um levantamento bibliográfico acerca das temáticas nucleares do estudo que se encontra a seguir. Posteriormente, procedeu-se a uma pesquisa de campo em uma renomada escola particular da zona sul da cidade de São Paulo, amplamente reconhecida pelo uso de tecnologias digitais em suas práticas pedagógicas. Durante a investigação, verificou-se que a escolha e o uso desses materiais fazem parte de uma complexa trama que envolve diversas dimensões como espaço, tempo, proposta pedagógica, área do conhecimento, professores, estudantes e suas formas de aprender.

Desse modo, este capítulo, destinado a tratar da metodologia da pesquisa, está dividido em cinco partes. A primeira aborda o levantamento bibliográfico realizado acerca dos suportes de escrita e as tecnologias digitais na educação, apontando para as contribuições desta pesquisa. A segunda parte anuncia o caminho percorrido para a escolha da instituição, a fim de desenvolver este estudo. Já a terceira caracteriza o colégio escolhido para o campo e a sua relação com as tecnologias digitais. Segue-se com a apresentação e caracterização dos sujeitos desta pesquisa. Por fim, a quinta parte traz as dimensões que balizaram a análise dos cadernos analógicos e digitais.

\subsection{DIÁLOGOS COM O CAMPO EDUCACIONAL: ESTUDOS REALIZADOS E AS CONTRIBUIÇÕES DA PESQUISA DESENVOLVIDA}

A fim de mapear as pesquisas sobre cadernos escolares e as tecnologias digitais nas escolas, foi realizado um levantamento de dissertações, teses e artigos nas bases de dados no Catálogo de Teses e Dissertações da Coordenação de Aperfeiçoamento de Pessoal de Nível Superior (CAPES) e na Biblioteca Digital Brasileira de Teses e Dissertações (BDTD) do Instituto Brasileiro de Informação em Ciência e Tecnologia (IBICT) ${ }^{7}$ ao final do primeiro semestre de 2019. Neles, buscou-se os seguintes termos: caderno escolar, cadernos escolares,

\footnotetext{
${ }^{7}$ Biblioteca Digital Brasileira de Teses e Dissertações, desenvolvida pelo Instituto Brasileiro de Informação em Ciência e Tecnologia, que integra os sistemas de informação de teses e dissertações existentes nas instituições de ensino e pesquisa do Brasil (INSTITUTO BRASILEIRO DE INFORMAÇÃO EM CIÊNCIA E TECNOLOGIA, [20--], online).
} 
suporte de escrita, suportes de escrita, caderno digital, cadernos digitais, tecnologias digitais. Posteriormente, tentou-se refinar o levantamento ao se utilizar filtros (assunto, área) de ambas as plataformas de busca.

Todavia, acabou-se optando por utilizar apenas os resultados encontrados na BDTD. Isso porque, além de se ter encontrado números expressivos de trabalhos no Catálogo da Capes (sempre acima de 1 milhão em cada busca), houve também grande dificuldade ao se recorrer a filtros na plataforma, uma vez que frequentemente dá erro quando se tenta fazê-lo. Quando isso ocorre, o usuário é redirecionado para a primeira página do filtro selecionado, tendo que remarcar tudo novamente.

Dessa forma, dos trabalhos encontrados na BDTD, foram selecionados aqueles que continham pelo menos um daqueles termos no título, nas palavras-chave ou no resumo e que tratavam do uso de suportes de escrita pelos alunos. Ao realizar a primeira busca, a saber, “caderno escolar" OU “cadernos escolares", selecionando a opção "todos os campos”, foram encontrados 40 trabalhos, dentre os quais sete se enquadravam nesses critérios de seleção (BELARMINO, 2015; BRANDÃO, 2010; JACQUES, 2011; MORAES, 2016; NEUBERT, 2013; SANTOS, A., 2002; 2008).

Posteriormente, buscou-se por "suporte de escrita" OU "suportes de escrita", também selecionando "todos os campos", e se obteve 31 resultados. Nenhum dos quais, porém, obedecia àqueles critérios. Então, pesquisou-se por "caderno digital” OU “cadernos digitais", e, de igual modo, nenhum trabalho foi selecionado dos 5 resultados devolvidos pela plataforma.

Finalmente, decidiu-se combinar "tecnologias digitais" a quatro dos termos já pesquisados. Tanto na busca por "tecnologias digitais" e "caderno escolar" quanto por “tecnologias digitais" e "cadernos escolares", não houve qualquer resultado. Todavia, quando se buscou por "tecnologias digitais" e "suporte de escrita", obteve-se como resultados dois trabalhos, dos quais nenhum atendia aos critérios de seleção. O mesmo ocorreu quando se pesquisou por "tecnologias digitais" e "suportes de escrita".

Por essa razão, à parte os sete trabalhos mapeados a partir das buscas na BDTD, apresenta-se, a seguir, 16 textos que se mostraram importantes, conseguidos a partir das referências bibliográficas dessas e de outras obras a que se teve acesso. As produções (um total de 23) estão organizadas por ordem cronológica nos quadros abaixo, os quais estão divididos 
em seis classificações temáticas ${ }^{8}$ nesta ordem: trabalhos que fundamentam teoricamente o estudo sobre os cadernos escolares (Quadro 1); trabalhos que tratam das funções e uso dos cadernos escolares (Quadro 2); trabalhos que tratam da materialidade dos cadernos escolares (Quadro 3); trabalhos que abordam os cadernos escolares como suportes de escrita e leitura (Quadro 4); trabalhos que tratam de tecnologias digitais na educação (Quadro 5); trabalhos que tratam de diversas abordagens tendo os cadernos escolares como objeto (Quadro 6).

Quadro 1 - Trabalhos que fundamentam teoricamente o estudo sobre os cadernos escolares

\begin{tabular}{|c|c|c|c|c|}
\hline Título & Autor & Ano & $\begin{array}{c}\text { Natureza } \\
\text { da } \\
\text { Publicação }\end{array}$ & $\begin{array}{c}\text { Local de } \\
\text { Publicação/ } \\
\text { Instituição }\end{array}$ \\
\hline $\begin{array}{c}\text { Por uma bibliografia material das } \\
\text { escritas ordinárias: O espaço gráfico do } \\
\text { caderno escolar (França - séculos XIX e } \\
\text { XX) }\end{array}$ & Jean Hébrard & 2001 & Artigo & São Paulo \\
\hline $\begin{array}{c}\text { Do currículo prescrito ao currículo } \\
\text { ensinado: um olhar sobre os cadernos } \\
\text { de classe }\end{array}$ & Silvina Gvirtz & 2005 & Livro & São Paulo \\
\hline $\begin{array}{c}\text { Cadernos à vista: escola, memória e } \\
\text { cultura escrita }\end{array}$ & $\begin{array}{c}\text { Ana Chrystina } \\
\text { Venancio } \\
\text { Mignot (org.) }\end{array}$ & 2008 & Livro & Rio de Janeiro \\
\hline
\end{tabular}

Fonte: Elaborado pela Autora (2021).

Desses 3 trabalhos, nos quais se embasou a pesquisa que resultou nesta dissertação, o primeiro ao qual se faz referência é o de Hébrard (2001). Nesse artigo, o autor trata do papel fundamental do caderno escolar a partir do momento em que as escolas francesas se propuseram a difundir diversos "savoir-faire". Assim sendo, esse trabalho trata da constituição dos cadernos como um material que passa a fazer parte das escolas francesas a partir do século XIX como suporte para todos os tipos de exercícios, cópias, escrita de listas e tabelas e até como forma de

\footnotetext{
${ }^{8}$ Além dessas cinco classificações, há outra: trabalhos que abordam a guarda da escrita escolar. Contudo não se constitui como um eixo central para esta pesquisa. Entre os estudos dessa temática, destacam-se: Museu da escola de Minas Gerais: um projeto a serviço de pesquisadores docentes (1998) de Ana Maria Casassanta Peixoto; Fim do mundo: avaliação. Preservação e descarte documental (2000) de Diana Gonçalves Vidal; A escrita nossa de cada dia: sonhos impressos em iniciativas de preservação da memória escola (2003) de Ana Chrystina Venancio Mignot; Papeis guardados (2003) e Da gaveta à vitrine: exposições sobre a escrita (2006), também da Mignot; Velhos cadernos, novas emoções (2008) de Mirian Paura Sabrosa Zippin; Cadernos Escolares: revelando a doutrinação da infância pelo Regime Militar - 1964-1985 (2009) de Antonio Gomes Ferreira e Ariclê Vechia; Janelas indiscretas: os cadernos escolares na historiografia da educação (2010) de Ana Chrystina Venancio Mignot; Nos cadernos escolares de um passado recente: uma história do ensino da leitura no estado do Espírito Santo (2013) de Fernanda Zanetti Becalli; Entre zonas de sombra: apontamentos sobre as escritas infantis (2014) de Ana Chrystina Venancio Mignot.
} 
agenda. Desse modo, o aluno passa a lidar com a organização do espaço gráfico, a própria escritura e o domínio do tempo de seus trabalhos.

Do currículo prescrito ao currículo ensinado, por sua vez, é fruto da tese de doutorado de Silvina Givirtz, defendida em 1996 em Buenos Aires. O livro traz o caderno como um dispositivo e está organizado em seis capítulos: micropoder na escola; a configuração histórica dos cadernos de classe; as atividades e a confirmação do discurso escolar; o caderno e a administração dos saberes curriculares; as descontinuidades do caderno: alcances e limites.

Já o livro Cadernos à vista: Escola, memória e cultura escrita (2008a), organizado por Ana Chrystina Venancio Mignot, tem como objetivo evidenciar a necessidade de preservação desses papéis escolares, ainda que esquecidos, trazendo à luz os cadernos, objetos que guardam a memória da educação. Ele conta com quinze trabalhos e está estruturado em torno de quatro eixos: balanço dos estudos feitos no âmbito da historiografia da educação; produção e circulação dos suportes e utensílios da escrita escolar; os usos dos cadernos escolares; e iniciativas pessoais e familiares de salvaguarda desses documentos produzidos durante a trajetória escolar.

Quanto aos trabalhos que abordam a função e o uso dos cadernos escolares, verificouse que duas dissertações se encaixam nessa temática, como ilustra o quadro seguinte:

Quadro 2 - Trabalhos que tratam das funções e uso dos cadernos escolares

\begin{tabular}{|c|c|c|c|c|}
\hline Título & Autor & Ano & $\begin{array}{c}\text { Natureza da } \\
\text { Publicação }\end{array}$ & $\begin{array}{c}\text { Local de } \\
\text { Publicação/ } \\
\text { Instituição }\end{array}$ \\
\hline $\begin{array}{c}\text { Cadernos escolares na } \\
\text { primeira série do ensino } \\
\text { fundamental: funções e } \\
\text { significados }\end{array}$ & $\begin{array}{c}\text { Anabela Almeida } \\
\text { Costa e Santos }\end{array}$ & 2002 & Dissertação & $\begin{array}{c}\text { Universidade de } \\
\text { São Paulo }\end{array}$ \\
\hline $\begin{array}{c}\text { Os sentidos atribuídos } \\
\text { pelas crianças aos seus } \\
\text { cadernos escolares }\end{array}$ & $\begin{array}{c}\text { Caroline Guião } \\
\text { Coelho Neubert }\end{array}$ & 2013 & Dissertação & $\begin{array}{c}\text { Universidade } \\
\text { Federal de Santa } \\
\text { Catarina }\end{array}$ \\
\hline
\end{tabular}

Fonte: Elaborado pela Autora (2021).

A pesquisa de mestrado de Anabela Santos (2002) dedicou-se a investigar as funções e os significados dados aos cadernos escolares no primeiro ano do Ensino Fundamental de uma escola pública. Nela, constatou-se que esse é um importante instrumento didático no início do processo de alfabetização. Com o mesmo recorte, Neubert (2013) também averigua os usos e os sentidos dos cadernos escolares atribuídos pelas crianças no primeiro ano do Ensino Fundamental. Interessante notar que, nessa pesquisa, os dados analisados mostraram o quanto 
os sentidos atribuídos pelos professores a este material diferem daqueles oferecidos pelas crianças já nesse primeiro ano.

$\mathrm{Na}$ terceira temática em que os trabalhos foram classificados, conforme Quadro 3, listam-se uma dissertação e um artigo relacionados aos cadernos escolares e à materialidade desses artefatos:

Quadro 3 - Trabalhos que tratam da materialidade dos cadernos escolares

\begin{tabular}{|c|c|c|c|c|}
\hline Título & Autor & Ano & $\begin{array}{l}\text { Natureza da } \\
\text { Publicação }\end{array}$ & $\begin{array}{c}\text { Local de } \\
\text { Publicação/ } \\
\text { Instituição }\end{array}$ \\
\hline $\begin{array}{c}\text { Educação e cultura visual: } \\
\text { apropriações da publicidade } \\
\text { e das logomarcas no caderno } \\
\text { escolar e o imaginário } \\
\text { estudantil }\end{array}$ & $\begin{array}{l}\text { Maria Aparecida de } \\
\text { Oliveira Brandão }\end{array}$ & 2010 & Dissertação & $\begin{array}{c}\text { Pontifícia } \\
\text { Universidade } \\
\text { Católica de São } \\
\text { Paulo }\end{array}$ \\
\hline $\begin{array}{l}\text { A celebração do luxo nas } \\
\text { capas de cadernos escolares }\end{array}$ & $\begin{array}{c}\text { Flávia Mayer dos } \\
\text { Santos Souza, Maria } \\
\text { Nazareth Bis Pirola, } \\
\text { Moema Lucia Martins } \\
\text { Rebouças }\end{array}$ & 2015 & Artigo & São Paulo \\
\hline
\end{tabular}

Fonte: Elaborado pela Autora (2021).

Brandão (2010) busca descrever e analisar os tipos de relações que podem ser estabelecidas entre a cultura midiática visual no campo da publicidade e o imaginário infantil. Para tanto, baseia-se nas logomarcas das capas dos cadernos escolares no mundo da cultura e da moda streetwear, surfwear e skateboard de alunos do Ensino Fundamental e Médio da rede pública da cidade de Mauá em São Paulo.

Já a publicação de Souza, Pirola e Rebouças (2015) investiga como os produtos escolares têm se apropriado do consumo de luxo da moda e da tecnologia, analisando capas de cadernos das coleções "Turma da Lala" e Poo Fashion da marca Credeal. O artigo considera as capas como parte de uma complexa trama que aproxima as indústrias de materiais escolares, brinquedos e comunicação.

Além de terem sido publicados em 2016, o artigo e a dissertação, indicados no Quadro 4, também têm em comum a característica de considerarem os cadernos escolares como suportes de leitura e escrita: 
Quadro 4 - Trabalhos que abordam os cadernos escolares como suportes de escrita e leitura

\begin{tabular}{|c|c|c|c|c|}
\hline Título & Autor & Ano & $\begin{array}{l}\text { Natureza da } \\
\text { Publicação }\end{array}$ & $\begin{array}{l}\text { Local de } \\
\text { Publicação/ } \\
\text { Instituição }\end{array}$ \\
\hline $\begin{array}{l}\text { Redações, cartas e composições } \\
\text { livres: O caderno escolar como } \\
\text { objeto da cultura material da escola } \\
\text { (Lages/Sc - 1935) }\end{array}$ & $\begin{array}{c}\text { Tania } \\
\text { Cordova }\end{array}$ & 2016 & Artigo & Santa Catarina \\
\hline $\begin{array}{l}\text { A leitura nos anos finais do ensino } \\
\text { fundamental: um diálogo com os } \\
\text { professores e as atividades de leitura } \\
\text { registradas em cadernos escolares }\end{array}$ & $\begin{array}{l}\text { Sandrina } \\
\text { Wandel Rei } \\
\text { de Moraes }\end{array}$ & 2016 & Dissertação & Espírito Santo \\
\hline
\end{tabular}

Fonte: Elaborado pela Autora (2021).

O artigo de Cordova (2016) investigou as práticas de escrita em um caderno de produção de textos de uma aluna do ano de 1935 da Escola Normal de Lages, Santa Catarina. Nesse estudo, o caderno se constituiu em um documento que possibilitou vislumbrar parte do currículo prescrito, do trabalho pedagógico e de tipos de escritas da normalista. Além disso, permitiu compreender apropriações e usos desse objeto que extrapolam a função prescrita de registro do processo de aprendizagem. Já a pesquisa de Moraes (2016) teve como objetivo a investigação de concepções de linguagem e leitura nas práticas dos professores referentes às atividades de leitura registradas nos cadernos dos alunos.

No que se refere aos trabalhos relacionados às tecnologias digitais na educação, identificou-se seis obras entre dissertações, teses e artigo, conforme indicadas no quadro abaixo:

Quadro 5 - Trabalhos que tratam de tecnologias digitais na educação (continua)

\begin{tabular}{|c|c|c|c|c|}
\hline Título & Autor & Ano & $\begin{array}{c}\text { Natureza da } \\
\text { Publicação }\end{array}$ & $\begin{array}{c}\text { Local de } \\
\text { Publicação/ } \\
\text { Instituição }\end{array}$ \\
\hline $\begin{array}{c}\text { Tecnologia na educação: As } \\
\text { representações de docentes } \\
\text { nas séries iniciais }\end{array}$ & Thalis Telemberg & 2004 & Dissertação & $\begin{array}{c}\text { Universidade } \\
\text { Federal de Santa } \\
\text { Catarina }\end{array}$ \\
\hline $\begin{array}{c}\text { Mudança de geração na era } \\
\text { digital: o professor de } \\
\text { matemática e seus alunos }\end{array}$ & $\begin{array}{c}\text { Jaqueline Di } \\
\text { Gaspari }\end{array}$ & 2013 & Dissertação & $\begin{array}{c}\text { Fniversidade } \\
\text { Fedal de São } \\
\text { Um carlos }\end{array}$ \\
$\begin{array}{c}\text { Umputador por aluno: } \\
\text { modernização da escola } \\
\text { brasileira na segunda } \\
\text { década do século XXI }\end{array}$ & $\begin{array}{c}\text { Luani de Liz } \\
\text { Souza, Lisley } \\
\text { Canola Treis }\end{array}$ & 2015 & Artigo & Minas Gerais \\
\hline
\end{tabular}


(conclusão)

\begin{tabular}{|c|c|c|c|c|}
\hline $\begin{array}{c}\text { Cadernos, pincéis e } \\
\text { netbooks: modulações } \\
\text { tecnológicas em uma escola } \\
\text { da rede pública de ensino } \\
\text { básico }\end{array}$ & $\begin{array}{c}\text { Fúlvia da Silva } \\
\text { Spohr }\end{array}$ & $\mathbf{2 0 1 5}$ & Tese & $\begin{array}{c}\text { Universidade } \\
\text { Federal do Rio } \\
\text { Grande do Sul }\end{array}$ \\
\hline $\begin{array}{c}\text { A aprendizagem da escrita } \\
\text { no ensino fundamental II } \\
\text { com o auxílio de suportes } \\
\text { digitais }\end{array}$ & $\begin{array}{c}\text { Érika Christina } \\
\text { Köhle }\end{array}$ & 2016 & Dissertação & $\begin{array}{c}\text { Universidade } \\
\text { Estadual de São } \\
\text { Paulo }\end{array}$ \\
\hline $\begin{array}{c}\text { Apropriação da linguagem } \\
\text { escrita por meio de } \\
\text { aplicativos em dispositivos } \\
\text { digitais }\end{array}$ & $\begin{array}{c}\text { Sônia de Oliveira } \\
\text { Santos }\end{array}$ & 2019 & Tese & $\begin{array}{c}\text { Entadual de São } \\
\text { Paulo }\end{array}$ \\
\hline
\end{tabular}

Fonte: Elaborado pela Autora (2021).

Em sua pesquisa, Telemberg (2004) analisa as concepções tanto de tecnologia quanto de tecnologia educacional de professores das séries iniciais do Ensino Fundamental, tendo em vista a inserção das Tecnologias de Informação e Comunicação (TIC) nos ambientes escolares. Seu estudo constatou que a utilização das tecnologias de suporte informático se mantinha circunscrita a um paradigma convencional de ensino, baseadas em concepções tecnicistas e instrucionistas, prevalecendo a introdução dessas tecnologias de maneira desarticulada e descontextualizada.

Gaspari (2013), por sua vez, visa refletir acerca das mudanças ocorridas dentro das salas de aula, em especial nas aulas de Matemática, proporcionadas pela revolução tecnológica, informática e digital. Nesse estudo foi constatado que, ainda que tenha havido algumas mudanças, o ensino tradicional prevalece nas aulas dessa disciplina, as novas tecnologias aparecem como suporte do professor no momento do planejamento, e, para os alunos, como entretenimento.

O artigo de Souza, Teixeira e Carminati (2015) trata da análise do Programa Um Computador por Aluno (PROUCA), que fez parte das políticas públicas educacionais no Brasil mais especificamente nas mudanças curriculares e aprendizagem colaborativa entre as escolas do PROUCA em Santa Catarina. Nesse estudo, buscou-se compreender as relações entre o laptop e alguns elementos suscitados com o propósito de inovação.

Já Spohr (2015) acompanha em sua pesquisa o processo de distribuição de netbooks a uma comunidade escolar da rede de Ensino Fundamental, observando alguns efeitos éticos, estéticos e políticos e com base no encontro dos sujeitos com a tecnologia. Notou-se que a modulação de uma rede inclui políticas públicas em educação, a potência de indeterminação 
das tecnologias os sujeitos. Esses três elementos aparecem como inseparáveis ao conceber as tecnologias como uma postura ética e de autoria.

Na sequência, a dissertação de Köhle (2016) pretende compreender de que maneira o uso de determinadas estratégias de ensino possibilitaria inserir estudantes do sexto ano do Ensino Fundamental II no mundo da escrita, tendo como um de seus objetivos a comprovação das contribuições dos suportes digitais para o ensino do ato de escrever. Parte dessa pesquisa se trata, exatamente, de como novas possibilidades de construção textual passaram a existir com o surgimento dos computadores e outros aparelhos digitais e sua popularização.

Por fim, Santos (2019) teve como objetivo, em seu estudo, compreender como as crianças se apropriam da linguagem escrita por meio do uso do aplicativo de mensagens em smartphones, WhatsApp, e por meio da construção de narrativas no programa Word em computadores. A tese defende que o uso dos dispositivos é essencial no processo de apropriação da escrita, uma vez que, ao utilizá-los, a criança tem acesso a recursos que a ajudam na construção, inscrição e elaboração da escrita.

Como se pôde verificar, são diversas as abordagens dos estudos que têm como objeto e fonte os cadernos escolares. Viñao (2008) aponta que, em pesquisas como essas, desde o final da década de 1990, há o cruzamento de três campos historiográficos complementares, embora com interesses e enfoques diferentes: a história da infância, a da educação e a da cultura da escrita. De acordo com o autor,

Os cadernos foram utilizados como fonte para o conhecimento das imagens e representações sociais sobre a infância, a escola, a família e outros temas similares; como instrumentos de aculturação escrita; como veículos transmissores de valores e atitudes ou um modo de doutrinação ideológica e política; como uma forma a mais de trabalho dos alunos junto aos exercícios e folhas soltas. E, ainda, como meio para estudo do currículo e das diferentes disciplinas e atividades escolares [...], como uma inovação educativa dentro do movimento internacional da Escola Nova e como um instrumento de expressão pessoal e subjetiva do aluno. Também, como era de se esperar, despertou interesse o estudo de seus aspectos materiais [...], de sua iconografia [...] e de seus diferentes usos [...] não faltam estudos sobre suas características como fonte histórica. (VIÑAO, 2008, p. 18).

Diante da diversidade de estudos em relação ao enfoque - temas e usos dos cadernos escolares como fonte histórica -, alguns trabalhos relevantes para a presente pesquisa não se enquadraram em nenhuma categoria temática acima, mas são apresentados a seguir: 
Quadro 6 - Trabalhos que tratam de diversas abordagens tendo os cadernos escolares como objeto

\begin{tabular}{|c|c|c|c|c|}
\hline Título & Autor & Ano & $\begin{array}{l}\text { Natureza da } \\
\text { Publicação }\end{array}$ & $\begin{array}{l}\text { Local de } \\
\text { Publicação/ } \\
\text { Instituição }\end{array}$ \\
\hline $\begin{array}{l}\text { No caderno da criança, o retrato } \\
\text { da escola }\end{array}$ & $\begin{array}{l}\text { Vitoria Libia } \\
\text { Barreto de Faria }\end{array}$ & 1988 & Dissertação & $\begin{array}{l}\text { Universidade } \\
\text { Federal de } \\
\text { Minas Gerais }\end{array}$ \\
\hline $\begin{array}{l}\text { Caderno Escolar: um dispositivo } \\
\text { feito peça por peça para } \\
\text { produção de saberes e } \\
\text { subjetividades }\end{array}$ & $\begin{array}{l}\text { Vera Mendes } \\
\text { dos Santos }\end{array}$ & 2002 & Artigo & Santa Catarina \\
\hline $\begin{array}{l}\text { Cadernos e outros registros } \\
\text { escolares da primeira etapa do } \\
\text { ensino fundamental: um olhar da } \\
\text { psicologia escolar crítica }\end{array}$ & $\begin{array}{l}\text { Anabela } \\
\text { Almeida Costa e } \\
\text { Santos }\end{array}$ & 2008 & Tese & $\begin{array}{l}\text { Universidade de } \\
\text { São Paulo }\end{array}$ \\
\hline $\begin{array}{l}\text { De como a Didatização separa a } \\
\text { aprendizagem histórica do seu } \\
\text { objeto: um estudo a partir da } \\
\text { análise de cadernos escolares }\end{array}$ & $\begin{array}{l}\text { Marlene } \\
\text { Terezinha } \\
\text { Grendel }\end{array}$ & 2009 & Tese & $\begin{array}{l}\text { Universidade } \\
\text { Federal do } \\
\text { Paraná }\end{array}$ \\
\hline $\begin{array}{c}\text { Entre atividades, cadernos e } \\
\text { portifólios: análise dos saberes e } \\
\text { materiais utilizados na educação } \\
\text { infantil }\end{array}$ & $\begin{array}{l}\text { Marelenquelem } \\
\text { Miguel }\end{array}$ & 2010 & Dissertação & $\begin{array}{l}\text { Universidade } \\
\text { Federal de Santa } \\
\text { Catarina }\end{array}$ \\
\hline $\begin{array}{c}\text { As marcas de correção em } \\
\text { cadernos escolares do curso } \\
\text { primário do Colégio } \\
\text { Farroupilha/RS 1948/1958 }\end{array}$ & $\begin{array}{l}\text { Aline Rigoni } \\
\text { Jacques }\end{array}$ & 2011 & Dissertação & $\begin{array}{c}\text { Pontifícia } \\
\text { Universidade } \\
\text { Católica do Rio } \\
\text { Grande do Sul }\end{array}$ \\
\hline $\begin{array}{l}\text { Entre bordados, cadernos e } \\
\text { orações: a educação de meninas e } \\
\text { as práticas educativas no } \\
\text { orfanato de São Cristóvão e na } \\
\text { escola da Imaculada Conceição } \\
(1922-1969)\end{array}$ & $\begin{array}{l}\text { Josineide } \\
\text { Siqueira de } \\
\text { Santana }\end{array}$ & 2011 & Dissertação & $\begin{array}{l}\text { Universidade } \\
\text { Federal de } \\
\text { Sergipe }\end{array}$ \\
\hline $\begin{array}{c}\text { Os cadernos escolares que } \\
\text { "falam": artefato de subjetivação } \\
\text { de gênero e sexualidade }\end{array}$ & $\begin{array}{l}\text { Natália } \\
\text { Machado } \\
\text { Belarmino }\end{array}$ & 2015 & Dissertação & $\begin{array}{l}\text { Universidade } \\
\text { Federal de } \\
\text { Pernambuco }\end{array}$ \\
\hline
\end{tabular}

Fonte: Elaborado pela Autora (2021).

Assim, percebe-se que há considerável quantidade de estudos, alguns mais recentes, que fazem uso dos cadernos escolares como fonte ou objeto de pesquisa de áreas como currículo, transmissão de valores e ideologias, perspectiva histórica e atual. Há também um número notável, ainda que menor, de estudos sobre as tecnologias digitais no contexto escolar. Nesse sentido, é interessante destacar que dos 23 trabalhos apontados nesta pesquisa, 12 deles são 
dissertações, cinco são artigos, há também quatro teses e dois capítulos de livros. Destes, há dez trabalhos anteriores ao ano de 2010 e 13 publicações deste ano em diante, salientando que existem sete estudos publicados somente entre os anos de 2015 e 2016. Como se pôde verificar nos quadros, quase que a totalidade das publicações são da região Sudeste (14 trabalhos) e Sul (sete obras), sendo duas dissertações da região Nordeste.

Diante do exposto, vale ressaltar que a originalidade da pesquisa reportada nesta dissertação se deve ao fato de não haver (ou não se ter identificado) estudos que tenham investigado se as tecnologias digitais, quando inseridas na escola como suportes de escrita, acrescentam aspectos favoráveis e potencialidades ou se apenas substituem o uso dos cadernos de papel na perspectiva dos estudantes, ou ainda se tem suas utilizações concomitantes.

\subsection{DAS FONTES DOCUMENTAIS E DO CAMINHO PARA A PESQUISA DE CAMPO}

Embora as fontes nucleares da pesquisa tenham sido os registros dos estudantes em seus cadernos analógicos e digitais, as respectivas entrevistas, as observações de aulas e as conversas informais com as professoras, também utilizou-se fontes documentais, tanto oficiais quanto da escola. Relativamente a essas fontes, foram analisados três documentos oficiais que tratam sobre o uso das tecnologias digitais nas instituições de ensino, tais como: as Diretrizes Curriculares Nacionais (DCN), publicadas em 2013, em cuja sessão denominada “Organização Curricular" há apontamentos sobre a utilização das TIC; a Base Nacional Comum Curricular (BNCC), publicada em 2017, documento normativo que define as aprendizagens que alunos de todo o país devem desenvolver ao longo da escolaridade e na qual a tecnologia assume um papel relevante, visto que das dez competências gerais expressas, três envolvem a questão das tecnologias digitais; e, por fim, também analisou-se o Currículo da cidade de São Paulo, que trata sobre as tecnologias.

Afora o plano legal, examinou-se dados sobre o uso das tecnologias digitais na educação e em escolas, coletados em 2019 e publicados em 2020 pelo Centro Regional de Estudos para o Desenvolvimento da Sociedade da Informação (Cetic.br). Tais dados visam mapear o acesso, o uso e a apropriação das TIC em escolas públicas e privadas de educação básica, contemplando diferentes dimensões de análise como, instituições, alunos, professores, coordenadores e diretores. A pesquisa desenvolvida pelo Cetic.br conta com o apoio institucional do Ministério da Educação (MEC), do Instituto Nacional de Estudos e Pesquisas Educacionais Anísio Teixeira (Inep), da Organização das Nações Unidas para a Educação, a Ciência e a Cultura (Unesco), do Conselho Nacional de Secretários de Educação (Consed), da União Nacional dos 
Dirigentes Municipais de Educação (Undime) e de outros especialistas vinculados a organizações não governamentais. Considera-se que esses dados contribuem para a presente pesquisa, pois, por meio deles, pode-se situar a escola em que a pesquisa foi realizada. Além disso, ao comparar os usos das tecnologias digitais para a aprendizagem dos sujeitos deste estudo com tais dados, é possível estabelecer relações entre os perfis de uso das ferramentas de tecnologias digitais, as habilidades no uso dos dispositivos e as competências desenvolvidas.

Já no que diz respeito às fontes documentais da própria instituição que fez parte desta pesquisa (escola que será caracterizada e discutida à frente), foi realizada a leitura e a análise destes documentos contidos em seu site : Visão educacional, que expressa a busca pelo constante aperfeiçoamento do currículo, da metodologia e das práticas pedagógicas, tendo como base o desenvolvimento das habilidades socioemocionais, o esporte e a excelência acadêmica, preparando estudantes para acessarem renomadas universidades nacionais e internacionais; Proposta pedagógica, o qual expressa a valorização do aluno, do professor e de uma estrutura tecnológica educacional, mantendo relação com o mundo em constantes transformações; Quem somos, cujo texto apresenta o colégio e seus principais pressupostos, dentre os quais a valorização da expressão e do conhecimento de seus estudantes, a formação permanente dos educadores e o foco no desenvolvimento dos alunos por meio de uma educação que responda às demandas contemporâneas; Propósito, missão, visão e valores, que, além de definir cada um desses aspectos, expressa que o trabalho da escola tem um norte ético, moral e profissional; Manifesto, o qual, segundo o próprio documento, foi criado pelo colégio, mas contempla os diferentes agentes da educação (alunos, professores, funcionários, familiares, cultura e mídia); Liderança no mercado, que salienta a característica de se manter viva, sempre atenta em responder às demandas do século; um impresso chamado Educação para hoje e para o futuro, publicado em 2020, que aborda a história e os pilares da instituição, bem como seus propósitos e concepções. Todos esses documentos mencionam com frequência a inquietude dos funcionários da escola na busca de estarem a frente do tempo, procurando inovações e práticas pedagógicas que engajem os alunos, em ressonância com as habilidades e competências valorizadas atualmente; por isso, auxiliaram na percepção de como a escola em que a pesquisa foi realizada compreende a inovação.

É relevante destacar que houve dificuldade de se encontrar, inicialmente, uma instituição escolar onde a pesquisa pudesse ser desenvolvida. A princípio, pensou-se em realizar tal investigação em uma escola pública da cidade de São Paulo de ciclo I. A Faculdade de Educação da Universidade de São Paulo tem parceria com escolas públicas de todos os níveis, nas quais há educadores que orientam e apoiam estudantes na realização de estágio e pesquisa. 
Dessa forma, pretendia-se desenvolver a pesquisa em uma dessas "escolas campo", uma vez que essa parceria facilitaria o contato com a direção e a receptividade dos alunos. Todavia, nenhuma delas - fosse de Ensino Fundamental I ou II - se destacava pelo uso das tecnologias digitais por parte dos alunos. Fez-se, então, uma busca na internet, em páginas de redes sociais, em matérias de portais de notícias, procurando-se escolas inovadoras nesse sentido. Porém, não foram encontradas instituições públicas na cidade de São Paulo. O passo seguinte foi acionar contatos de colegas e indicações de professores da rede pública, mas a tentativa também não foi bem-sucedida.

Por esse motivo e pensando no conceito de inovação, decidiu-se que a busca não seria mais por instituições escolares, mas por práticas docentes ainda de escolas públicas da cidade de São Paulo que utilizassem as tecnologias digitais e que conjecturasse os usos dos cadernos. Assim sendo, optou-se pela rede municipal de ensino por considerar que seria mais profícua, visto que ela possui um programa de Tecnologias para Aprendizagem. De acordo com informações do site da Secretaria de Educação, o núcleo tem como objetivo "integrar e articular ações de aprendizagem que envolvam o uso das Tecnologias Digitais da Informação e Comunicação (TDIC) nas unidades escolares da rede, a partir da formação de professores e elaboração de programas e projetos para este fim.” (SÃO PAULO, [201-?]a, online).

O programa oferece, segundo esse site, estrutura física e pedagógica para as escolas, uma vez que todas as unidades escolares de Ensino Fundamental, Médio, Educação Bilíngue e Centros Integrados de Educação de Jovens e Adultos da rede estão equipadas com: conexão à internet cabeada e $W i$-fi; laboratórios de informática com 21 computadores; projetor interativo multimídia; impressoras; webcams e softwares para alunos com necessidades educacionais especiais. Além disso, os alunos de Ensino Fundamental e Médio têm uma aula de informática semanal no horário regular das aulas e contam com a regência de Professores Orientadores de Informática Educativa (POIEs). Ademais, também estão previstos horários de pesquisa fora do horário regular de aula, conforme está disposto na Portaria $\mathrm{n}^{\circ} 7.655 / 15$, de 17 de dezembro de $2015^{11}$ (SÃO PAULO, 2015).

Ainda de acordo com aquele site, o Núcleo de Tecnologias para Aprendizagem tem como diretrizes para a ação pedagógica:

I - o currículo na perspectiva emancipatória e integradora, tendo a dialogicidade como norteador do trabalho pedagógico e o ambiente escolar como local de promoção do protagonismo do educando, com a ressignificação dos conteúdos, articulados à realidade social;

\footnotetext{
${ }^{11}$ Foi revogada pela Instrução Normativa SME no 26/2018 (SÃO PAULO, 2018) e, posteriormente, pela Instrução Normativa SME nº 30/2019 (SÃO PAULO, 2019).
} 
II - a Unidade Educacional como espaço de criação e recriação de cultura digital e dos conteúdos, tendo os educandos e docentes como produtores e consumidores conscientes desta cultura, a partir da mediação, compreensão e expressão das linguagens digitais;

III - as Tecnologias de Informação e Comunicação - TICs, como possibilidades de organização das iniciativas pedagógicas e da comunicação entre os educandos e educadores e destes com o conhecimento;

IV - o registro das práticas pedagógicas como instrumento que acompanhe o educando na avaliação do seu processo de aprendizagem;

$\mathrm{V}$ - a valorização dos saberes e desenvolvimento das potencialidades dos educandos, tendo como pilares a compreensão, experimentação, colaboração e a capacidade de construir conhecimentos;

VI - a criação de ambientes estimuladores e colaborativos, com estratégias diversificadas no trabalho com projetos didáticos, podendo, inclusive, utilizarse da robótica, gamificação, cultura maker, raciocínio lógico espacial e pensamento crítico reflexivo no desenvolvimento de uma postura investigativa;

VII - a sistematização dos conteúdos produzidos coletivamente, a partir da decisão também coletiva de compartilhamento e do uso dos Recursos Educacionais Abertos.

Isto visa promover ações de cunho pedagógico que contribuam para o desenvolvimento de cidadãos ativos do século XXI. (SÃO PAULO, [201-?]a, online).

O site da Secretaria Municipal de Educação também informa sobre a formação do POIE. Em um contexto em que a presença da tecnologia no currículo demanda repensar meios de comunicação, metodologias e práticas sociais entre os alunos, e refletindo sobre espaços e tempos de aprendizagem, o professor que atua nos laboratórios de informática possui um papel importante como parceiro e potencializador de processos para a "vivência, disseminação e contextualização do uso das tecnologias digitais ao processo de ensino-aprendizagem, de forma interdisciplinar” (SÃO PAULO, [201-?]b, online). Face a isso, a secretaria municipal de educação cita que há uma ação de formação continuada para esses professores.

Diante do exposto, fez-se um primeiro contato em uma Diretoria Regional de Educação, a fim de buscar uma instituição com POIEs de referência. Apesar de ter tido contato de duas professoras de duas escolas diferentes, a pesquisa não se tornou viável pois o uso que se fazia das salas de informática não era expressivo. Assim, assinala-se que, embora tenha havido uma exaustiva busca por uma instituição pública e/ou por práticas pedagógicas nessas instituições, em que os alunos fizessem, de fato, uso das tecnologias digitais, estas não foram encontradas. Tal fato certamente é um dado importante para este estudo.

Tendo em vista o contexto apresentado, optou-se por procurar uma instituição de ensino privada que se destacasse publicamente pelo uso das tecnologias digitais. Assim, fez-se novamente uma pesquisa em páginas de redes sociais, em matérias de portais de notícias e em 
páginas da internet, em especial no site do Porvir ${ }^{12}$. Seguindo recomendações de profissionais da área, selecionou-se, primeiramente, três escolas potenciais para a pesquisa, até que, finalmente, chegou-se, em junho de 2019, até a escola onde a pesquisa foi aceita e realizada.

\subsection{A INSTITUIÇÃO PESQUISADA E SUAS RELAÇÕES COM A TECNOLOGIA}

Com o objetivo de investigar os usos e os desusos dos cadernos escolares no contexto das tecnologias digitais, de modo a analisar e verificar se quando estão inseridas na escola, apenas substituem o uso do caderno ou acrescentam inovações e oferecem potencialidades ou têm seus usos concomitantes, foi realizada uma pesquisa de campo, envolvendo docentes e, principalmente, estudantes, de uma renomada escola particular da cidade de São Paulo. O critério de escolha dessa instituição foi ela ser amplamente reconhecida pela presença marcante do uso das tecnologias digitais não só pelos professores, como também pelos seus alunos, visto que os tablets são materiais de uso individual obrigatórios e por se constituir assim, nesse ponto de vista, em uma escola inovadora.

A escola ${ }^{13}$ onde se desenvolveu a pesquisa foi fundada em 1944. De acordo com informações retiradas do site da escola, naquela época, já se tinha a preocupação em formar alunos aptos a lidar com os desafios de seu tempo, mostrando, então, características de uma instituição arrojada, inovadora e que prima pelo pioneirismo. Localizado na zona Sul da cidade e com a extensão de um quarteirão, o colégio atende alunos de famílias de classe média-alta e alta dos ciclos do Ensino Fundamental II e Ensino Médio. De acordo com dados do regimento da escola, em 2020, havia aproximadamente três mil alunos, sendo divididos entre aqueles matriculados no Ensino Fundamental II, que acontece no período vespertino, e os matriculados no Ensino Médio, no período matutino. Lecionam nessa instituição cerca de 150 professores, e 100 funcionários, aproximadamente, trabalham nas áreas de suporte pedagógico e administrativa. Assim, levando em conta o grande número de funcionários, estudantes e famílias com diferentes valores, crenças e origens, a multiplicidade e a diversidade são valores centrais do colégio, como é apontado no documento "Visão educacional", contido no site da instituição.

\footnotetext{
${ }^{12}$ De acordo com informações do próprio site, o Porvir é a principal plataforma de conteúdos e mobilização sobre inovações educacionais do Brasil. Desde 2012, mapeia, produz e difunde referências para inspirar e apoiar transformações que garantam equidade e qualidade na educação a todos os estudantes brasileiros. Mantido durante sete anos pelo Instituto Inspirare, em 2019 tornou-se uma organização autônoma e sem fins lucrativos (PORVIR, [20--]).

${ }^{13}$ Por questões éticas, foi garantido o anonimato da escola.
} 
De acordo com os documentos do site, e uma publicação impressa elaborada pela própria instituição, a escola - tendo a primazia pela excelência acadêmica de seus estudantes espera alta performance nas provas e nos processos seletivos nacionais, como no Exame Nacional do Ensino Médio (Enem) e em outros vestibulares bastante concorridos do país, e internacionais, em universidades do exterior. No site, menciona-se, ainda, que a valorização do conhecimento, da expressão de seus alunos e da formação contínua de seus docentes são estratégias adotadas pelos gestores para construir uma educação que responda às questões do século 21.

Além disso, outro valor que a escola mostra ser relevante é a constante busca por atualização e inovação de práticas pedagógicas, visando estimular em seus alunos o gosto e a curiosidade pelo conhecimento e pelo aprendizado. Não raro, encontre-se menção sobre a importância da inovação, na própria expressão deles, em seus documentos e publicação. Desse modo, de acordo com a obra impressa, desde os anos 1990, o colégio vem buscando expandir seu papel na formação dos alunos, investindo recursos, criando diferentes espaços e incentivando a formação de seus professores para o trabalho, com aspectos que vão além do acadêmico, a exemplo das habilidades socioemocionais.

Segundo os dados de documentos disponibilizados no site, a escola foca no jovem e está sempre atenta ao desenvolvimento de uma educação contemporânea que leve em consideração o contexto de mundo conectado, complexo e com abundantes informações. Nesses documentos afirma-se que a escola está implicada, junto aos seus estudantes, na busca por soluções para a construção de significado e da curadoria dos conteúdos nos meios virtuais, assim como procura apoiá-los no desenvolvimento de habilidades socioemocionais por meio do trabalho com a empatia, a criatividade e a resiliência.

Ademais, essa instituição de ensino se destaca há bastante tempo no que se refere à tecnologia educacional. De acordo com uma publicação do próprio colégio, em 1995, foi inaugurado o Laboratório Multidisciplinar (LMD), que era utilizado por professores das diferentes disciplinas e tinha a proposta de se utilizar softwares, desenvolver propostas com as ferramentas de Power Point, Word e Excel. O problema é que a escola tinha muitos alunos para um único laboratório e, por isso, cada turma acabava indo somente duas ou três vezes ao longo do bimestre. Sendo assim, no início dos anos 2000, há uma ampliação do LMD.

Em 2010, os IPads são lançados no mercado, e a instituição vê esse equipamento como uma alternativa para expandir efetivamente o LMD. Então, em 2011, o colégio compra IPads para serem compartilhados entre os alunos como um laboratório móvel. Diante dessa mudança, como consta na publicação feita pelo colégio, todo o trabalho pedagógico que fazia uso da 
tecnologia foi revisado e adaptado, uma vez que a lógica de uso do tablet é bastante diversa do computador. Ainda que a aquisição dos tablets tenha representado de fato uma ampliação do LMD, a demanda pelo uso dos equipamentos continuou crescendo e, em 2014, o tablet passa a fazer parte da lista de materiais obrigatórios dos estudantes do $6^{\circ}$ ano do Ensino Fundamental. É certo de que essa mudança evocou mudanças pedagógicas e de infraestrutura.

De acordo com a publicação impressa produzida pelo próprio colégio, a possibilidade de cada um ter uma máquina digital em suas mãos, muda a relação entre os sujeitos e, por conseguinte, a dinâmica da sociedade, tornando-a menos hierárquica e muito mais em rede. Assim, o grande mérito do colégio, conforme a publicação, foi incorporar em sua pedagogia a cultura digital já amplamente disseminada na sociedade. Dessa maneira, o uso do tablet ou do smartphone é constante, tanto pelos estudantes, quanto pelos professores e funcionários, em todo espaço escolar. Essas ferramentas fazem parte do material obrigatório, ou seja, é possível assegurar que se vive um ensino híbrido, compreendendo o papel e ao mesmo tempo o digital, uma vez que há agenda, boletim escolar, aplicativos e materiais didáticos virtuais e apostilas no formato e-books. Tal organização só foi possível por meio do forte investimento do colégio em infraestrutura digital que conta com mais de 150 antes de Wi-fi e de 2.1 gigabytes que possibilitam a conexão de 3.600 máquinas concomitantemente.

Segundo funcionários do departamento de tecnologia da instituição, foi proposital a mudança acontecer a partir do $6^{\circ}$ ano do Ensino Fundamental ao invés das séries do Ensino Médio. Isso porque a escola considerou que haveria menor resistência a essa mudança tanto por parte dos professores quanto em relação aos alunos. Ademais, esses funcionários explicam que muitas novidades chegam até a escola por meio dos alunos dos sextos anos, ao mesmo tempo que estudantes do $3^{\circ}$ ano do Ensino Médio apresentam certa resistência a algumas mudanças. Além disso, a alteração seria sequenciada de modo que a cada ano esse material se tornaria obrigatório para a série seguinte, culminando depois de alguns anos na mudança da escola como um todo. Porém, a mudança aconteceu de maneira mais acelerada na medida em que alunos e professores foram vendo as potencialidades do equipamento.

O uso das tecnologias digitais nessa escola está alicerçado em três principais pilares. O primeiro é o ambiente virtual de aprendizagem, o Moodle, o qual é organizado por disciplinas e possui uma série de ferramentas que apoiam o trabalho do professor, como realização de questionários, entrega de trabalhos, lições de casa, compartilhamento de vídeos e outras mídias. O segundo são os livros e as apostilas digitais que se constituem em materiais produzidos pela própria equipe pedagógica do colégio em parceria com a equipe de tecnologia educacional da instituição, para que nesses materiais haja hiperlinks, vídeos e animações. O terceiro eixo diz 
respeito aos aplicativos produzidos pela própria equipe de tecnologia educacional da escola, que conta com um departamento para esse fim. Os documentos da instituição expressam que esses três pilares da base de dados têm quatro objetivos principais no trabalho dos estudantes criatividade, colaboração, comunicação e pensamento crítico. Desse modo, todo conteúdo está em formato digital, ainda que as apostilas de exercícios e os cadernos façam parte da lista dos materiais obrigatórios dos alunos.

Todo esse investimento na tecnologia educacional fez com que a escola conquistasse certificados de duas das maiores empresas de tecnologia do mundo, a Apple Distinguished Program e a Microsoft Showcase School. Além do mais, o uso de ferramentas Power BI como suporte para decisões administrativas e pedagógicas é referência mundial da Microsoft.

\subsection{DOS SUJEITOS DA PESQUISA E DAS OBSERVAÇÕES DE SITUAÇÕES DIDÁTICAS: DOIS CENÁRIOS}

Esta seção destina-se a tratar dos sujeitos da presente pesquisa. Escolheu-se os sextos anos, pois é a série de entrada na instituição e, por isso, considerou-se que seria interessante investigar como a mudança de ter um tablet como material obrigatório impacta na vida escolar dos alunos. Além disso, durante as primeiras conversas com membros da coordenação do colégio para a apresentação da pesquisa, foi mencionado por eles que os estudantes mais novos, os do sexto ano, são mais abertos às mudanças, sendo estes que, por vezes, trazem novidades de fora da escola para dentro da instituição. Ao passo que os alunos mais velhos, em especial do Ensino Médio, frequentemente são mais resistentes a alterações.

Todavia, durante as conversas iniciais com a coordenadora da área de Língua Portuguesa, foi dito que uma das professoras mais bem avaliadas do colégio, de acordo com a opinião dos alunos, era uma das professoras de Língua Portuguesa de sétimo ano. Portanto, também se optou por acompanhá-la. Além disso, durante esse período, realizou-se a leitura dos documentos oficiais do colégio disponibilizados no site da instituição no segundo semestre de 2019. Porém, como mencionado, este estudo foi entrecruzado pela pandemia do novo Coronavírus, o que implicou numa mudança de cenário. Por isso, depois de um semestre de adaptação a esse novo modelo, o contato com o colégio e as professoras foi retomado, de modo que as entrevistas com alguns dos alunos que foram acompanhados no primeiro momento tiveram que acontecer de maneira virtual, meses depois, em novembro de 2020.

Cada turma de sextos e sétimos anos possui, em média, 30 estudantes, que passam o período de cinco horas e meia com seis aulas diárias, cada uma das quais durando 50 minutos, 
e um intervalo de meia hora, durante os cinco dias da semana. O currículo conta com seis aulas semanais de Matemática, cinco de Língua Portuguesa, quatro de Ciências, três de História, três de Inglês, três de Espanhol, duas de Geografia, duas de Educação Física, uma de Artes e uma de Convivência Positiva em Grupo (CPG), a qual tem como base assuntos ligados à convivência, à sexualidade, ao bullying e às drogas.

Depois de algumas conversas com coordenadores da instituição, a fim de que entendessem as intenções deste estudo, eles propuseram que, ao invés de acompanhar um único grupo durante todo o período de aulas, as observações e a coleta de dados acontecessem em apenas uma disciplina, já que cada área do conhecimento possui uma coordenação diferente e, dessa forma, seria mais fácil a aceitação e a participação na pesquisa. Definiu-se então, em agosto de 2019, em conjunto com o colégio, acompanhar as aulas de Língua Portuguesa dos sextos anos, visto que é a de entrada dos alunos na escola, ou seja, momento em que esses alunos passam pela transição de estarem inseridos em uma escola com uso de cadernos de papel como suporte de escrita para outra que possui o tablet como material obrigatório.

As aulas de Língua Portuguesa do sexto ano eram ministradas por três professoras ${ }^{14} \mathrm{com}$ perfis distintos, segundo a própria coordenadora da área: Marcia, uma docente mais experiente, que leciona há muitos anos na escola; Isabela, uma professora bem jovem, uma das mais novas tanto em termos de idade quanto de tempo na escola; e Laura, também jovem, mas já com vários anos de experiência em sala de aula. Outrossim, a própria coordenadora da área recomendou que se acompanhasse também uma outra docente, a Marina, uma das professoras do sétimo ano, que está entre as melhores docentes de acordo com avaliações feitas pelos alunos.

Desde então, foi quase um semestre de observação com idas de duas a três vezes na semana entre o fim de agosto e dezembro de 2019. À medida que as visitas foram acontecendo, duas das professoras do sexto ano se mostraram muito abertas e receptivas, do mesmo modo que a do sétimo ano. Todavia, a professora Marcia, do sexto ano, revelou-se um pouco mais fechada ao acompanhamento das aulas, razão pela qual se decidiu realizar a pesquisa apenas com as turmas daquelas três docentes.

Tanto o acompanhamento das aulas quanto as conversas mais estruturadas com os estudantes continuariam em 2020. Contudo, logo no início do ano, o mundo se deparou com a pandemia do novo Coronavírus, e, ainda que as aulas estivessem acontecendo normalmente, decidiu-se, juntamente com a coordenação da área de Língua Portuguesa da escola, que o

\footnotetext{
${ }^{14}$ Por questões éticas, serão usados nomes fictícios.
} 
melhor seria aguardar para compreender como a situação se desenrolaria. Em meados de março, no entanto, foi decretado o fechamento das escolas e a adoção das aulas remotas.

Frente a esse cenário, a pesquisa foi interrompida, na expectativa de que a pandemia terminasse e que, em breve, as aulas pudessem ser retomadas presencialmente, assim como esta investigação. Como se sabe, porém, infelizmente, não foi o que ocorreu. No decorrer das semanas, alunos e professores de todo o país (assim como no mundo inteiro) tiveram que lidar com um novo contexto de educação e aprender a construírem, juntos, uma nova escola. A nível nacional, são inúmeros os impactos das crianças longe das escolas: falta de recursos digitais, grande lacuna na formação dos professores para usar tais ferramentas, aumento da ansiedade nas crianças, dificuldades de aprendizagem, desafio da inclusão de alunos com deficiência, conciliação entre a necessidade de apoio dos familiares para que as crianças se conectassem e se envolvessem nas aulas e a necessidade de esses adultos trabalharem, entre tantas outras adversidades que marcaram esse período.

Pode-se destacar, todavia, o enfrentamento com maior robustez, em certa medida, do preconceito das aulas a distância como um aspecto positivo imposto pelo imperativo das aulas remotas, afinal esse formato era o único possível naquele momento. Outro ponto favorecido foi a avaliação e a reflexão que se tornaram indispensáveis à escola, uma vez que foi praticamente impossível não conjecturar sobre a pertinência de conteúdos e estratégias, repensando, assim, a educação e a instituição escolar como um todo. Acredita-se que não será possível voltar para a escola que se tinha antes de 2020, ainda que em uma instituição com o uso consolidado das tecnologias digitais, como a que foi acompanhada nesta pesquisa, pois foi necessário rever currículo e práticas pedagógicas de um modo jamais visto.

No que se refere a esta investigação, também foi impactada e teve seus objetivos repensados, uma vez que não se podia mais pensar em suportes de escrita de papel ou digitais sem considerar esse momento tão singular da educação. Afinal, em que momento dessa educação prioritariamente digital é utilizado o caderno analógico? Há alguma mudança na maneira de registrar as aulas ministradas por vídeo e os encontros síncronos feitos presencialmente na escola? Há novos canais de registro nesse contexto? O que já faziam antes e que reverberam nesse novo modelo? Assim, após alguns meses de adaptação a esse novo contexto e novas conversas com a coordenação da escola, permitiu-se que acontecessem entrevistas online com os alunos.

Fez-se, então, novos contatos com as professoras de Língua Portuguesa. No entanto, Laura estava de licença maternidade. Quanto a Marina, prontamente se disponibilizou a contribuir e viabilizar o contato com os estudantes, ao passo que não houve resposta da Isabela. 
Desse modo, a pesquisa continuou apenas com o apoio da professora Marina, que, em 2019, lecionava para os alunos do sétimo ano e, era conforme a avaliação deles, uma das melhores professoras da instituição.

Nesse formato remoto, de acordo com conversas online e informais com Marina, os estudantes tinham acesso ao roteiro de estudo via Moodle, as aulas aconteciam exclusivamente por meio de vídeos, e havia encontros síncronos periódicos para plantão de dúvidas. Tinha-se como intenção participar dos encontros ao vivo para que se pudesse selecionar os alunos para uma entrevista. Porém, não foi permitido pela instituição participar desses momentos, devido à proteção de imagem dos alunos nesse ambiente online. Aconteceram, no entanto, várias conversas informais com a professora para que ela contasse sobre o funcionamento da escola e pudesse compreender as novas intenções da pesquisa. Assim sendo, diante desse cenário, ela selecionou oito alunos para participarem da coleta de dados, dentre os quais seis concordaram em participar do estudo. Não houve critério para escolha e participação dos estudantes na pesquisa, pois questões como gênero, desempenho escolar ou outros fatores não foram considerados. Marina fez a seleção dos alunos de acordo com características como solicitude, abertura, engajamento, a fim de que houvesse adesão à pesquisa

Face ao exposto, fez-se contatos via $e$-mail e, posteriormente, marcou-se chamadas por vídeo para realizar entrevistas individuais semiestruturadas e a fim de possibilitar uma análise mais detida, comparar e confrontar os discursos. Dos seis alunos, cinco são meninas e um menino, todos estudantes de sétimos anos, ou seja, estavam nas turmas de sextos anos acompanhadas em 2019:

Quadro 7 - Estudantes entrevistados de acordo com as suas séries

\begin{tabular}{|c|c|}
\hline Estudante & Série \\
\hline Gabriela & $7^{\circ} \mathrm{E}$ \\
\hline Julia & $7^{\circ} \mathrm{A}$ \\
\hline Lorena & $7^{\circ} \mathrm{B}$ \\
\hline Roberta & $7^{\circ} \mathrm{B}$ \\
\hline Tomás & $7^{\circ} \mathrm{A}$ \\
\hline Valentina & $7^{\circ} \mathrm{E}$ \\
\hline
\end{tabular}

Fonte: Elaborado pela Autora (2021).

As entrevistas individuais tiveram duração aproximada de 20 minutos cada e foram transcritas ${ }^{15}$ integralmente, com o intuito de analisar e categorizar os dados. Dos aspectos

\footnotetext{
${ }^{15}$ As transcrições das entrevistas estão nos apêndices desta dissertação.
} 
contemplados no roteiro da entrevista, tem-se: os materiais utilizados para fazer os registros escolares; as justificativas da preferência do suporte de escrita; o que costuma registrar; os momentos de retomada das anotações; as possíveis mudanças no modo de fazer os registros e no suporte de escrita durante o ensino remoto; o uso de caneta para tablets e seus impactos na utilização do equipamento; o compartilhamento de cadernos; a importância e as funções dos cadernos de papel e do tablet.

Durante as conversas, os estudantes mostravam seus cadernos e registros ilustrando suas falas. Além disso, solicitou-se que eles enviassem fotos dos seus cadernos para uma análise mais minuciosa, a fim de compreender o modo como cada estudante faz seus registros, o que há de comum entre eles, o que, como e de quais naturezas são as anotações pessoais e estabelecer relações e distinções entre os cadernos analógicos e digitais. Inicialmente, foram fotos de páginas dos seus cadernos, analógicos e/ou digitais, escolhidas por eles, somando 32 registros fotográficos. Após a sistematização e a análise dessas imagens, fez-se um novo pedido de fotos, via e-mail, de maneira que houvesse imagens dos cadernos dos mesmos componentes curriculares e dos mesmos conteúdos para que, desse modo, fosse possível analisar e estabelecer relações de maneira mais profícua. Com exceção da Julia, todos os estudantes, solícitos e muito gentilmente, enviaram os registros fotográficos solicitados. Obteve-se, assim, 81 fotos, que foram categorizadas em uma tabela de dupla entrada, cruzando os alunos e a área de conhecimento e conteúdo dos registros.

A partir da leitura dos documentos da instituição, do acompanhamento das aulas por quase um semestre, das conversas com as três professoras de Língua Portuguesa, da realização das entrevistas individuais com os seis estudantes e das análises e sistematizações dos registros dos cadernos analógicos e digitais, verificou-se que a escolha e o uso desses materiais fazem parte de uma complexa trama. Esta envolve diversas dimensões como espaço, tempo, proposta pedagógica, área do conhecimento, professores, sujeitos e suas formas de aprender, as quais serão exploradas a seguir.

\subsection{SUPORTES DE ESCRITA ESCOLARES NO FOCO: DIMENSÕES ANALISADAS}

Como se pôde verificar anteriormente, por vezes, o imperativo de mudanças na escola é a inserção ou a troca de materiais e objetos, como é o caso das tecnologias digitais. Entretanto, de maneira geral, não há, necessariamente, alterações de práticas pedagógicas. Tal efeito também pode ser observado com livros, carteiras individuais, giz, lousa, lápis, borrachas e, até mesmo, os cadernos, que promoveram modificações mais ou menos expressivas nas práticas 
pedagógicas, constatando-se algumas alterações e, ao mesmo tempo, permanências, como verificado, por exemplo, nos estudos de Mignot. Isso porque os cadernos e o uso das tecnologias digitais na escola dependem de uma série de fatores que fazem parte de uma trama tecida por diversos aspectos presentes na cultura escolar, em determinados momentos históricos e com suas peculiaridades - de modo especial, nas concepções pedagógicas em vigor -, nas condições socioeconômicas e características culturais presentes nas instituições educativas.

Assim, para uma análise mais minuciosa e apurada dos usos e desusos dos suportes de escrita em meio ao contexto digital, construiu-se um octógono ${ }^{17}$, que contempla as dimensões que dialogam com os suportes de escrita (cadernos e tablets), sendo essas interdependentes e interrelacionadas (ver Figura 1). O motivo de colocar os cadernos e os tablets no centro se deve ao fato de que esses são os objetos de investigação desta pesquisa.

Figura 1 - Octógono das dimensões do suporte de escrita

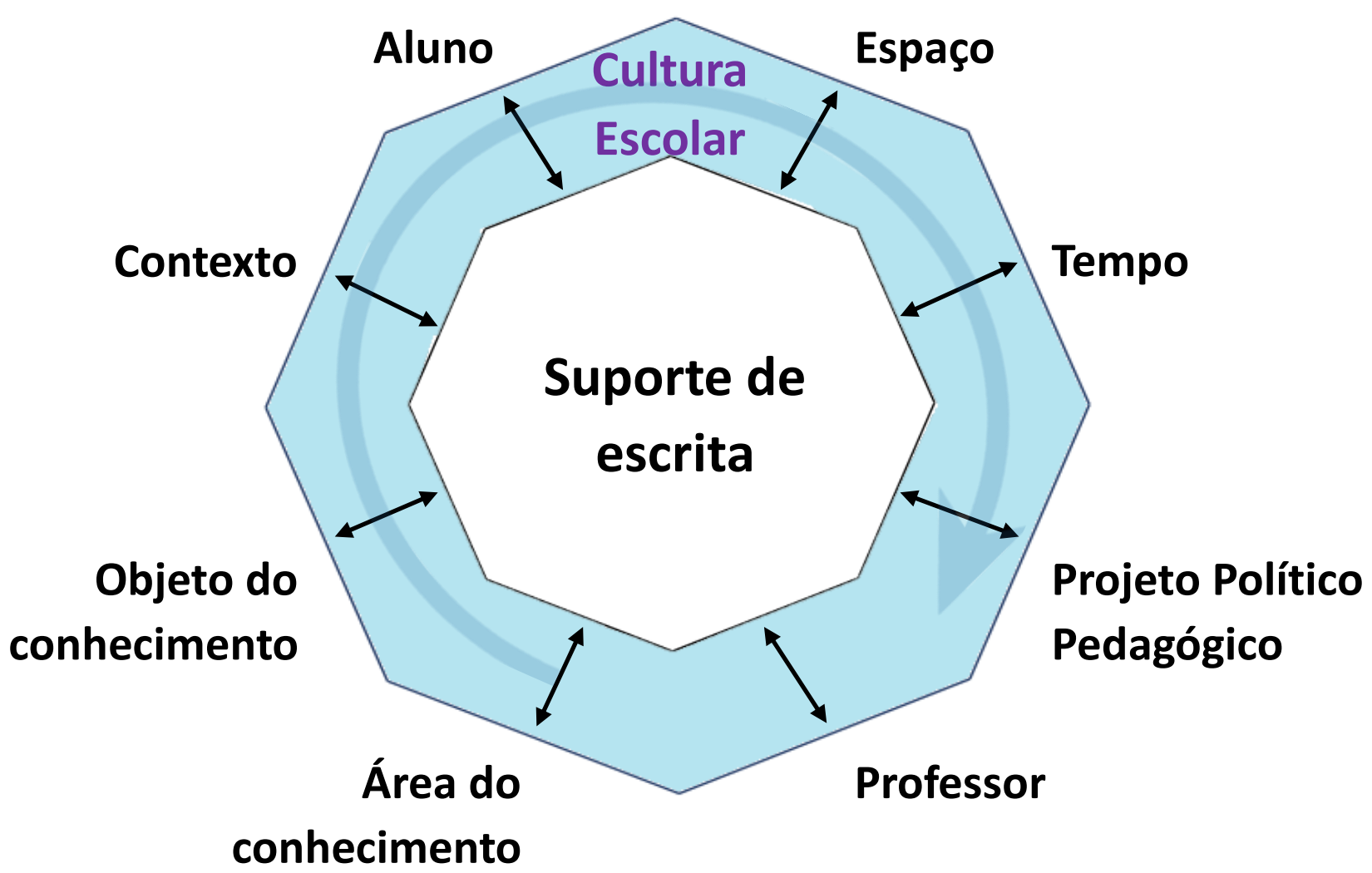

Fonte: Elaborado pela Autora (2021).

\footnotetext{
${ }^{17}$ A inspiração do octógono das dimensões dos suportes de escrita advém de Philippe Perrenoud em sua publicação Não mexa em minha avaliação! Uma abordagem sistêmica da mudança de 1999 pela Artmed, em que ele coloca a avalição no centro de um octógono de forças e insere oito pólos de tensão, quais sejam: 1- relações entre a família e a escola; 2- organização das turmas, individualização; 3- didática, métodos de ensino; 4- contrato didático, relação pedagógica, ofício de aluno; 5- acordo, controle, política institucional; 6- planos de estudo, objetivos, exigências; 7-sistema de seleção e orientação; 8- satisfações pessoais e profissionais.
} 
Concebe-se, aqui, os suportes de escrita afetando e sendo afetados por oito aspectos, todos integrantes e estruturantes da cultura escolar, como espaço e tempo. Explicitar-se-á, a seguir, cada uma dessas relações. Partir-se-á da dimensão do espaço, contornando o octógono no sentido horário.

\subsubsection{Espaço}

Os estudos de cultura escolar apontam para a dimensão educativa do espaço da escola. Frago (1998) afirma que todo sujeito que pretende ser educador, se quiser verdadeiramente sêlo, deve ser arquiteto. Assim, ainda que professores não tenham essa intenção ou consciência e mesmo que não alterem em nada o espaço da escola, são arquitetos, visto que, como o autor afirma, o espaço não é neutro e sustenta concepções. É preciso, portanto, encarar esse "lugar" da prática escolar como algo que sempre educa, que possui um papel ativo e revelador de discursos, muitas vezes implícitos, na forma escolar. Como também assevera Escolano (2001, p. 26),

o espaço escolar tem de ser analisado como um constructo cultural que expressa e reflete, para além de sua materialidade, determinados discursos. No quadro das modernas teorias da percepção, o espaço escolar é, além disso, um mediador cultural em relação à gênese e formação dos primeiros esquemas cognitivos e motores, ou seja, um elemento significativo do currículo, uma fonte de experiência e aprendizagem.

Desse modo, é preciso considerar que a disposição das carteiras, o local onde fica a lousa, o agrupamento dos alunos, interferem no modo de usar o caderno ou o tablet. Dito de outro modo, se há carteiras enfileiradas, uma lousa ou um projetor na frente da sala, estabelecendo uma relação frontal entre alunos e professores, pode-se prever que se preza pelo controle dos discentes, o que também impacta na forma como estes fazem seus registros. De acordo com Barra (2016, p. 18, grifo da autora),

a disposição espacial de uma escola organizada sob a forma da instrução simultânea de ensino prevê o controle sobre os olhares dos alunos por meio do direcionamento marcado pelo quadro-negro. Entende-se que a compreensão do itinerário da lousa seja uma das maneiras de entender os processos da conformação moderna da escola, cuja marca é a frontalização do ensino.

Aqui, destaca-se que, se o espaço é concebido nesses moldes, faz pouca diferença se há cadernos analógicos ou digitais, quadro-negro, lousa interativa ou projetor, uma vez que a frontalização do ensino ocorre da mesma forma. De modo diverso, se há uma outra configuração da sala de aula, de maneira em que o professor não fique o tempo todo à frente, 
como um maestro regendo sua orquestra, e as carteiras se dispõem de forma mais orgânica e menos rígida, prevalecendo uma organização que privilegie o trabalho em grupo e a troca de ideias entre todos, pode-se pensar em modos de registro mais colaborativos e cooperativos, sejam em papéis ou telas.

No entanto, é preciso pensar que, no ensino remoto, o espaço escolar e a plataforma das aulas online adentraram as casas de cada um desses alunos. Ou seja, nesse contexto, é precisamente o ambiente virtual de aprendizagem que se configura nesse papel de arquitetura da escola, afinal, são suas ferramentas que abrem possibilidades ou não para a interação com o conteúdo, professores e colegas de turma.

Conforme apontam Coll e Monereo (2010), a evolução das tecnologias supera a dimensão espacial, já que, mesmo os interlocutores estando a quilômetros de distância inclusive, um não sabendo onde o outro está fisicamente -, ainda assim, poder estabelecer um diálogo de maneira assíncrona ou síncrona. Segundo os autores, "o espaço virtual no qual ocorre a comunicação por redes, na verdade não é 'um lugar', um 'espaço físico' diferente dos espaços pessoais em que os interlocutores se encontram fisicamente." (COLL; MONEREO, 2010, p. 24).

Para além disso, é preciso ponderar o próprio caderno como um espaço a ser considerado. Isso porque ele já se transformou bastante, em termos materiais, ao longo do tempo e ainda pode assumir diversas facetas: tábuas de ardósia, que guardavam temporariamente os registros; os códex; as folhas soltas e posteriormente costuradas; cadernos espiralados, com folhas pautadas, quadriculadas, em branco, de tamanhos diversos; fichários; tablets. Cada um desses materiais guarda suas potencialidades e limitações que também se relacionam com a dimensão do tempo em que estão inseridos e são usados.

\subsubsection{Tempo}

De acordo com Gallego (2003, 2008), o tempo constitui-se em um sistema de referências temporais que organiza a vida social, a identidade dos indivíduos e das instituições, sendo um produto de cada sociedade. Para essa mesma pesquisadora, o tempo escolar, por sua vez, configura-se como um dos tempos sociais e como tal, é diverso e plural. Pode ser interpretado também como um conjunto de referências, a partir do qual, define-se, organiza-se e regula-se o funcionamento, a coordenação, o ritmo e a sincronização das interações de dentro da escola, sendo resultado de uma construção cultural e pedagógica, tendo assim, a sua história. Dessa forma, o tempo é um dos elementos centrais da cultura escolar e, assim como o espaço, também 
não é neutro. Segundo Frago (1996), o tempo escolar tem se constituído como um dos instrumentos mais perigosos para ser apresentado como algo mensurável, fragmentado, sequenciado, linear e objetivo.

Pode-se tratar essa dimensão sob estes dois aspectos: a mudança dos suportes escolares de escrita ao longo do tempo e a relação desses suportes com a otimização do tempo. Ao analisar a história e a constituição dos cadernos escolares, constata-se que esse foi um material que sofreu diversas alterações em seu percurso (FERNANDES, 2008; MIGNOT, 2008b; 2008c; VIÑAO, 2008). De início, a escrita era feita nas paredes das cavernas, nas pedras, depois em tabuinhas de ardósia, material que não possibilitava guardar e revisitar ao longo do tempo, sendo, portanto, uma anotação limitada do ponto de vista temporal. Posteriormente, vieram os pergaminhos e, com a crescente da indústria do papel, passou-se a registrar em papéis soltos, depois em papéis costurados, espiralados, chegando-se, posteriormente, aos aparelhos eletrônicos, como computadores e notebooks, que precisam ser teclados, até os tablets, que contam com a tecnologia touch screen.

Assim como os papéis, o instrumento de escrita também se alterou diversas vezes. De pena de animais, que exigiam muito tempo de preparação e pouca durabilidade, passou-se a utilizar penas metálicas, que eram um pouco mais resistentes e, posteriormente, canetas tinteiro, que exigiam mais tempo para a escrita, até chegar nas canetas esferográficas. Hoje, há diferentes canetas que são usadas nos equipamentos eletrônicos que cumprem a função da escrita ao invés da digitação.

Todas essas alterações também se relacionam com o segundo aspecto aqui mencionado, a otimização do tempo escolar. A cada nova tecnologia inserida na escola, o trabalho era favorecido no sentido de economizar o tempo e tornar mais prático o trabalho tanto de professores quanto de alunos. Isso também pode ser constatado com o uso do mimeógrafo, utilizado para fazer cópias em grande escala, poupando cópias da lousa e permitindo que estudantes fizessem suas atividades nas folhas soltas mimeografadas, colando-as, posteriormente, nos cadernos. Anos depois, o barateamento das xerox e fotocopiadoras permitiram que se otimizasse ainda mais o trabalho, visto que faziam cópias mais rapidamente, sem depender da força motriz e sem cheiro de álcool.

Com a crescente adoção de livros didáticos, também se percebem impactos na otimização do tempo no uso dos cadernos, uma vez que o conteúdo teórico se concentra nesse último material, permitindo que aconteçam menos cópias e fazendo com que o uso dos cadernos seja mais voltado para resolução de exercícios e anotações mais pessoais. 
Do mesmo modo, mais recentemente, há a entrada de computadores e tablets em algumas instituições escolares, como na que se realizou esta pesquisa. Isso favorece e impacta, mais uma vez, a otimização do tempo, posto que escrever leva mais tempo - geralmente, a escrita é mais lenta do que a digitação e demanda mais esforço físico; além de requerer mais movimentos, necessita de um suporte de escrita e um outro objeto, como lápis ou caneta. Por outro lado, celulares, notebooks ou tablets requerem menos tempo e esforço físico e precisam apenas do próprio aparelho e de energia para recarregar a bateria quando necessário.

Ademais, o contexto da massiva presença das tecnologias digitais na vida das pessoas para além das instituições escolares também altera a dimensão temporal na maneira de se relacionar com o mundo, já que praticamente não há mais espaço de tempo entre a informação e a sua disseminação, fazendo com que a comunicação aconteça velozmente. De outro modo, há uma separação nos tempos. Conforme apontam Coll e Monereo (2010, p. 24),

[...] a velocidade de transmissão da informação por redes o anula, praticamente, como condicionante para efeitos de comunicação; e, por outro, que ocorre uma dissociação entre o tempo pessoal, ou "tempo vivido", dos interlocutores e o tempo durante o qual se tem acesso à informação comunicada.

Essa mudança na maneira de se relacionar com as informações e com o mundo é ainda mais acentuada com o ensino remoto imposto pela pandemia. Esse formato fez com que os tempos escolares ficassem mais difusos para boa parte dos estudantes, visto que, ao invés de se ter aulas simultâneas de determinado conteúdo com todo o grupo reunido com certo professor, algumas instituições implantaram videoaulas, permitindo, assim, que cada aluno acessasse suas aulas no melhor horário, sem ter uma sequência pré-determinada de uma grade horária. Esse foi o caso da instituição pesquisada, na qual as aulas aconteciam por vídeo, as atividades eram postadas no Moodle, e eram garantidos encontros periódicos com professores, especialmente para tirar dúvidas. Assim, a aula de Língua Portuguesa não aconteceria, necessariamente, na segunda aula da terça-feira, por exemplo, em razão da flexibilização dos tempos, no sentido do horário. Além disso, permite algo inédito: que a mesma aula possa acontecer repetidas vezes, bastando somente reproduzi-la quando desejar.

Contudo, é preciso ponderar que, no contexto anterior ao da pandemia, não eram todas as escolas que aceitavam e permitiam o uso dos aparelhos tecnológicos digitais no seu interior. Possivelmente, com a retomada das aulas presenciais, muitas dessas instituições manterão a proibição ou o não uso. A propósito disso, trataremos na próxima dimensão do octógono. 


\subsubsection{Projeto político pedagógico}

O projeto político pedagógico da instituição escolar também é uma dimensão que interfere no suporte de escrita dos alunos, porquanto cada escola possui suas concepções de ensino, aprendizagem, conhecimento, avaliação, alunos e docentes. Essas concepções, por sua vez, determinam como se dá o processo educativo e balizam as práticas pedagógicas.

Assim sendo, entende-se que a aprendizagem acontece, por exemplo, por estímuloresposta. Por trás disso, tem-se uma concepção de que o aluno precisa memorizar e fixar informações, geralmente, das mais simples às mais complexas, sendo o professor o responsável por essa transmissão. A avaliação, portanto, incumbe-se de quantificar essas aprendizagens e informar aqueles que se saíram bem-sucedidos e aqueles que precisam fazer mais exercícios e memorizar tais conteúdos para avançar. Dessarte, o processo de ensino com essas concepções é caracterizado pelo investimento em cópias, ditados, memorização, realização de exercícios pré-determinados e, por conseguinte, o uso dos suportes de escrita também estarão a serviço dessas práticas.

De outro modo, se o conhecimento é concebido como algo que deva ser construído, pressupõem-se, aí, uma atividade tanto de quem aprende quanto de quem organiza, devendo este planejar boas situações de aprendizagem que visem levar o aluno a mobilizar seus conhecimentos já conquistados para avançar. Em tal caso, a avaliação pode ser um instrumento mais formativo, que indica possíveis rotas nesse processo de ensino e aprendizagem.

Nessa situação, o uso dos suportes de escrita pode se dar de um jeito diferente do citado anteriormente, com um uso mais pessoal, sem o contorno dado pelos professores e sem a necessidade de tantas cópias, mas com a presença de anotações que os estudantes acreditam que façam sentido e sejam úteis e importantes para cada um. Por conseguinte, a escolha do suporte de escrita também está condicionada ao projeto pedagógico, dado que esse suporte está expresso na lista de materiais, e é de acordo com suas concepções que a escola seleciona o mais adequado para atender seus objetivos e demandas.

Desse modo, se uma escola pressupõe o uso de suportes de escrita digitais ou se pretende ter as tecnologias presentes no cotidiano de alunos e professores, deve-se ter uma proposta mais ou menos explícita enquanto instituição, que evidencie sobre a forma de utilizá-las no desenvolvimento das atividades. Coll, Mauri e Onrubia (2010) apontam para a possibilidade de a escola delinear uma proposta que integre os aspectos pedagógicos e tecnológicos, construindo, assim, um projeto de currículo em que conste: 
[...] uma proposta de conteúdos, objetivos e atividades de ensino e aprendizagem, assim como orientações e sugestões sobre a maneira de desenvolvê-los; uma oferta de ferramentas tecnológicas; e uma série de sugestões e orientações sobre como utilizar essas ferramentas no desenvolvimento das atividades de ensino e aprendizagem. (p. 77-78).

Não obstante, faz-se necessário frisar que a escola e, consequentemente, o seu projeto político pedagógico, não estão suspensos no tempo e no espaço. Ainda, conquanto crie diversas dinâmicas sociais e culturais, a instituição escolar também se relaciona com pessoas concretas - professores e alunos -, que estão inseridas em um contexto também concreto. Portanto, qualquer proposta inscrita no projeto está sujeita às interpretações e concepções que os participantes fazem dele.

\subsubsection{Professor}

Como ressalta Julia (2001, p. 10-11, grifo nosso), a propósito do conceito de cultura escolar, "normas e práticas não podem ser analisadas sem se levar em conta o corpo profissional dos agentes que são chamados a obedecer a essas ordens”. Isso significa que a escola conta com profissionais reais, que possuem seus percursos de formação, crenças, concepções, valores, estão inseridos em determinadas áreas do conhecimento e possuem tempo de atuação e formação próprios. Conforme aponta Tardif (2002), há cinco classificações para identificar os saberes docentes: saberes pessoais dos professores; saberes provenientes da formação escolar anterior; saberes provenientes da formação profissional para o magistério; saberes provenientes dos programas e livros didáticos usados no trabalho; e, por fim, saberes provenientes de sua própria experiência na profissão, na sala de aula e na escola.

Desse modo, não se podem descartar os percursos formativos desde o início do processo educacional ainda como estudante, as experiências vividas na formação inicial e nos cursos de formação continuada, suas concepções, sua personalidade e seus valores, pois esses fatores impactam nas práticas pedagógicas docentes. É por esse motivo que, ainda haja diretrizes normativas e referenciais no projeto político pedagógico da instituição, haverá tantas práticas quantos professores existirem.

À vista disso, em uma mesma escola podem existir docentes que demandem diferentes usos dos suportes de escrita: alguns podem encarar os cadernos como um instrumento de controle daquilo que está sendo ensinado e aprendido; outros podem permitir um uso mais autoral, mas atribuir nota, desejando que tudo seja registrado; outros ainda, podem considerar como um objeto particular e prever um uso mais autônomo dos alunos. Também é possível que 
alguns professores exijam um tipo de suporte específico, enquanto outros podem deixar a escolha a critério dos estudantes.

Igualmente, ainda que a escola autorize o uso de aparelhos eletrônicos, é possível encontrar professores que se mostrem mais "fechados" ou resistentes, outros que tenham a iniciativa de usá-los de maneira disruptiva - bastante diversa do habitual -, além daqueles que, ao invés de passar o conteúdo na lousa, coloca-o em uma apresentação ou solicita que os alunos copiem em seus notebooks ou tablets ao invés dos cadernos, ou seja, utilizando novos recursos com base nas práticas tidas como tradicionais de ensino.

Como asseveram Coll, Mauri e Onrubia (2010), os professores inclinam-se a usar as tecnologias digitais de maneira coerente com seus pensamentos pedagógicos e concepções acerca dos processos de ensino e aprendizagem. Desse modo,

[...] com uma visão mais transmissiva ou tradicional do ensino e da aprendizagem, tendem a utilizar as TIC para reforçar suas estratégias de apresentação e transmissão de conteúdos, enquanto que aqueles que têm uma visão mais ativa ou "construtivista" tendem a utilizá-las para promover as atividades de exploração ou indagação de seus alunos, o trabalho autônomo e o trabalho colaborativo. (p. 75).

Ademais, os professores podem impactar no uso do suporte de escrita na medida em que servem de modelo para seus alunos. Isso quer dizer que a maneira como os docentes lidam com seus registros, expõem seus conteúdos e ministram suas aulas podem inspirar e criar repertório para os estudantes, constituindo-se em uma referência ou exemplo de como fazer e registrar.

\subsection{5 Área do conhecimento}

Para além das práticas de cada professor, a área do conhecimento no qual se está inserido também é uma importante dimensão a ser levada em conta quando se pensa nos suportes de escrita na escola, posto que as diferentes disciplinas tensionam distintos usos dos suportes de escrita, sejam eles analógicos ou digitais.

Então, algumas áreas do conhecimento oferecem a possibilidade de registros mais autorais, criativos, personalizados, como as Ciências Humanas e Naturais e as Línguas. Outras disciplinas, por sua vez, requerem um uso dos suportes de escrita mais voltado à resolução de exercícios, como é o caso da Matemática, por exemplo. Chervel (1990, p. 194) evidencia que “as condições materiais nas quais se dá o ensino estão estreitamente ligadas aos conteúdos disciplinares".

Portanto, não só a maneira como se usa esses suportes é afetada, como também a própria escolha. Na disciplina de Matemática, por exemplo, a menos que se tenha um tablet com uma 
caneta, o caderno de papel parece um instrumento mais fácil de manejar e fazer os cálculos do que digitar em um computador ou no tablet. Já pensando nas Artes ou na Geometria, muito possivelmente cadernos pautados não sejam os suportes mais adequados, pois as linhas podem atrapalhar ao invés de servirem de guia. Nesse caso, talvez os melhores suportes de papel sejam cadernos com folhas em branco ou quadriculados.

\subsubsection{Objeto do conhecimento}

Como se pôde averiguar, além da escolha e do uso dos suportes de escrita estarem relacionados à área do conhecimento, os diferentes objetos do conhecimento, por vezes, levam a distintos usos dos suportes dentro de uma mesma disciplina. Isso pode ser exemplificado nas aulas de Língua Portuguesa, nas quais o uso do suporte de escrita para planejar e redigir uma produção textual pode ser um; o de praticar exercícios de ortografia talvez seja outro bastante diferente; ainda, aquele utilizado em propostas de interpretação de texto tem a possibilidade de ser diverso dos suportes supracitados.

No primeiro caso, com o intuito de planejar uma redação, é possível valer-se de uma folha sem pautas para se fazer esquemas, mapas mentais com ideias para a estrutura do texto. Já para a escrita da redação, talvez o mais adequado seja uma folha pautada, um bloco de notas ou uma página de Word no computador ou tablet, que permitam apagar ou deslocar partes do texto sem ter de reescrevê-las por completo. Para a resolução de exercícios de ortografia, podese pensar em fazê-lo diretamente no livro didático ou na folha entregue pelo professor. Finalmente, no que concerne aos exercícios de interpretação de texto, pode-se pensar em um suporte que permita ao aluno entrar em contato com esse texto, riscando, grifando, sublinhando e fazendo suas anotações pessoais.

\subsubsection{Contexto}

É preciso estar ciente que, embora se tenha espaço e tempo marcados, projeto político pedagógico definido, professores com suas áreas e objetos do conhecimento, o uso dos suportes de escrita também dependem do contexto mais amplo em que se está inserido. Na verdade, aqui pode-se falar em contextos, no plural, pois é preciso levar em conta dimensões sociais, econômicas e geográficas, tanto dos alunos, quanto dos professores.

O Brasil é um país de tamanho continental marcado por profundas desigualdades. Se, por um lado, há muitas escolas sem mobiliário adequado e com condições muito adversas para 
receber seus docentes e estudantes, de outro, tem-se escolas com muita infraestrutura, ventilação, internet, equipamentos disponíveis para todos. Do mesmo modo, há estudantes que precisam enfrentar verdadeiras viagens para chegar até a escola, enquanto outros conseguem se deslocar confortavelmente por poucos quilômetros ou metros. Além disso, há professores que precisam custear do próprio bolso alguns materiais se querem oferecê-los em suas aulas, ao passo que outros não precisam ter essa preocupação, porque a escola os garante a todos.

Portanto, a escolha pelo suporte de escrita pode escapar de escolhas pedagógicas, concepções de ensino e aprendizagem e serem reféns das possibilidades do contexto no qual se está inserido. O ensino remoto trouxe ainda mais luz para essa questão, visto que muitos alunos ficaram à margem de aulas online simplesmente porque não havia a possibilidade de se ter um aparelho celular em casa ou acesso à internet.

\subsubsection{Aluno}

Além das dimensões mencionadas, é preciso considerar que o sujeito que utiliza os suportes de escrita exerce grande impacto sobre eles, posto que uma série de elementos relacionados a esse indivíduo, sua vida e suas preferências influenciam tanto o objeto em si, como seu uso, podendo então considerar os sujeitos como a oitava dimensão a ser contemplada.

É preciso ter em conta que a história e as condições de vida, a faixa etária e, portanto, suas experiências anteriores, refletem, em primeiro lugar, na escolha do material para suporte de escrita, bem como na maneira de usá-lo. Dessa forma, é comum que uma criança pequena que já esteja inserida em alguma instituição escolar tenha seu primeiro contato com um caderno ainda muito cedo, mas com um caderno de desenho, sem pautas. Ao final da etapa da Educação Infantil e início dos anos do Ensino Fundamental, suas escritas iniciam, muito comumente, em folhas soltas que, ao fim de cada período, são agrupadas, formando-se, em geral, um portfólio ou uma pasta de atividades. Em seguida, são introduzidos os cadernos com pautas, que implicam uma série de regras e normas de uso. Só depois de estarem apropriadas dessas prescrições é que se pode pensar em transgredi-las, possibilitando aos estudantes imprimirem marcas pessoais e fazerem escolhas por outras possibilidades materiais.

É certo que, dependendo de como foi sua trajetória e as diferentes vivências com suportes de escrita, abrem possibilidades para que os alunos ampliem seus repertórios e possam perceber suas preferências. Além disso, essas experiências ao longo da vida, dentro e fora da instituição escolar, vão marcando hábitos nos estudantes, fazendo com que se acostumem com certos materiais, criem suas estratégias de organização e de uso, influindo nas suas escolhas. 
Outro elemento que está relacionado ao aluno é o modo de apropriação pessoal do conhecimento, ou seja, como os sujeitos aprendem. Parte-se da ideia de que não há um único jeito de aprender, sendo essa uma tarefa pessoal, pois cada sujeito cria seus próprios mecanismos de aprendizagem. Portanto, tem-se aí outro fator que implica no uso dos suportes de escrita.

Por fim, um elemento que já foi mencionado indiretamente, mas que requer ênfase é a organização dos sujeitos. Cada aluno cria um modo de funcionamento e, portanto, suas estratégias particulares de organização, o que acabam por interferir em suas preferências, seus hábitos e, consequentemente, suas escolhas de materiais e nos seus usos.

É tendo em vista todas essas dimensões que um estudante opta por um único suporte de escrita ou um para cada disciplina, tendo diversas possibilidades a depender de todas as outras dimensões apontadas: uso de cadernos, fichários, tablets, cadernos de diferentes tamanhos, com linhas, folhas quadriculadas, pontilhadas, brancas, coloridas, com desenhos, diferentes ferramentas digitais, como bloco de notas, ou aplicativos diversos de anotações.

Entrecruzando as dimensões de professor e aluno, assinala-se, ainda, a influência nos usos dos suportes de escrita pelos valores que estão em jogo na relação professor-aluno e em seus cadernos, isto é, o que estudantes e docentes consideram como cadernos e registros bonitos ou feios, completos ou incompletos, suficientes ou insuficientes, adequados ou inadequados. Por vezes, essas inferências e expectativas estão alinhadas entre esses agentes; noutras tantas, são divergentes; constituem-se em julgamentos do aprender baseados no olhar e na verificação desses materiais e tem relação com as concepções de conhecimento e de aprendizagem.

No que se refere ao conhecimento, está relacionado justamente à finalidade do estudo. É comum verificar uma grande preocupação tanto de estudantes quanto de professores com avaliações; anota-se para estudar ou memorizar para as provas. Em contrapartida, pode-se partir da perspectiva de que existe uma relação singular entre os sujeitos e o conhecimento e que, portanto, os registros revelam essa relação.

Relativamente à aprendizagem, há docentes que desconsideram os modos pessoais de apropriação do conhecimento de seus alunos, confundindo o uso do caderno com garantias de aprendizagem, culminando, assim, em êxito nas avaliações. Por isso, exigem cadernos, sejam analógicos ou digitais, completos e bonitos. No entanto, não é possível inferir que não ter um caderno completo implica em não aprendizagem ou notas baixas. O contrário também é verdadeiro: é uma falácia crer que ter um caderno completo garante que os alunos tenham aprendido e tirem boas notas nas provas. 
Assim sendo, diante das dimensões de análise expostas nesta seção, considera-se relevante tratar da constituição dos suportes de escrita como materiais escolares, começando pelos cadernos e, mais recentemente, de como a entradas dos aparelhos digitais impactam nos usos e desusos desses objetos. Ademais, explicitar-se-á a prescrição do uso das tecnologias digitais nas escolas em documentos oficiais, confrontando com dados de acesso e utilização de ferramentas digitais. 


\section{TRADIÇÕES E IMPERATIVOS DE MUDANÇAS: COMO OS SUPORTES DE ESCRITA SE CONSTITUEM NAS ESCOLAS}

Este capítulo tem como objetivo elucidar os cadernos escolares como produto e produtor da cultura escolar e da cultura material escolar. Assim sendo, intenta-se mostrar como os suportes de escrita foram sendo incorporados pelas instituições de ensino, desde as tabuinhas de ardósia, passando pelas folhas soltas, chegando nos cadernos e, posteriormente, na entrada das tecnologias digitais nas escolas. Verifica-se que esse processo, longe de ser linear, é repleto de marcas de tradições e, ao mesmo tempo, de imperativos de mudanças que se mesclam e entrecruzam, fazendo com que, por vezes, a história pareça se repetir na inserção dos diferentes dispositivos. A entrada de novos materiais, neste caso, suportes de escrita, tende a desencadear novas significações a práticas em voga há certo tempo na cultura escolar. Algo importante de ser destacado é o fato de algumas dessas mudanças, como a inserção de suporte de escrita digitais na cultura escolar, estarem associadas a mudanças advindas do desenvolvimento humano, de descobertas científicas e de mudanças culturais, sociais e econômicas.

Como já mencionado, compreende-se que os objetos escolares são artefatos produzidos socialmente e que carregam marcas de seu tempo e espaço. Portanto, os cadernos são considerados produto da cultura escolar (LOPES, 2008; SANTOS, 2008a, VIÑAO, 2008). Segundo Santos (2008a), é necessário aprender o que se deve fazer, em quais momentos e de qual maneira para se inserir nessa cultura. Dessa forma, os cadernos fazem parte desses aprendizados. Também, de acordo com Viñao (2008), o caderno reflete a cultura da etapa, do nível ou do ciclo de ensino em que é utilizado. Assim, esse material revela a vida das instituições educativas e da sala de aula. Complementando essa ideia, Lopes (2008) afirma que os cadernos dão conta de falar sobre as práticas escolares, com base nas ideias de Gvirtz, a pesquisadora assinala que os cadernos são práticas discursivas escolares, ou seja, são também uma produção da escola.

É seguindo essa linha que os cadernos são vistos como dispositivos escolares (GVIRTZ; LARRONDO, 2008). Em outros termos, isso quer dizer que usar cadernos implica em saber regras. Nas palavras dessas autoras, um dispositivo escolar "é um conjunto de práticas discursivas escolares que se articulam de um determinado modo produzindo um efeito" (p. 39), sendo interessante compreender o caderno como um "conjunto de signos que se articulam e entrelaçam de modo particular, como práticas discursivas" (p. 40).

Faz-se necessário destacar que, apesar de os cadernos demandarem uma série de regras, em sua história dentro das escolas, é possível verificar rupturas, permanências e ressignificação 
de usos. Tal efeito vai ao encontro da definição elaborada por Frago (1998), segundo a qual, cultura escolar é tudo o que faz referência à escola, incluídas as manifestações instituídas em seu interior, realizadas tanto por alunos e professores quanto por normas e teorias. Em suas palavras, "a cultura escolar é toda a vida escolar: [...] neste conjunto há alguns aspectos que são mais relevantes que outros, no sentido que são elementos organizadores que a formam e definem" (FRAGO, 1998, p. 69).

Para esse autor, no entanto, não há uma única cultura escolar. Ele prefere usar o termo no plural: culturas escolares (FRAGO, 1996). Nesse sentido, a cultura escolar, em suma, é toda a vida da instituição: os fatos, as mentes, os corpos, as ideias, os objetos, as condutas, os modos de pensar, fazer e dizer, as normas, os rituais, os princípios, as práticas e os hábitos. Ou seja,

a cultura escolar é vista como um conjunto de teorias, princípios ou critérios, normas e práticas consolidadas ao longo do tempo no seio das instituições educativas. [...] Modos de pensar e atuar que se constituem, sempre estruturados em forma de discursos e ações, que, junto com a experiência e formação do professor, servem-lhe para realizar sua tarefa diária. (FRAGO, 1998, p. 169).

Além disso, o referido autor identifica a cultura escolar como um "conjunto de aspectos institucionalizados que caracterizam a escola como organização" (FRAGO, 1995, p. 68), incluindo, portanto, a história cotidiana do fazer escolar, que envolve modos de vida, condutas e práticas, ritos, hábitos. Abrange também os objetos materiais no que concerne ao uso, a introdução, a função, a materialidade, a distribuição no espaço, a simbologia, a transformação e o desaparecimento, abarcando os modos de pensar, assim como as ideias compartilhadas e os significados.

É importante destacar essa acepção, visto que, por vezes, como já evidenciado pelas ideias de Fullan (2009), tem-se a impressão de que a escola não muda, assim como pouco se alteram seus materiais. Todavia, ao considerar os objetos materiais e os seus aspectos, destacados por Frago (1995), e se aprofundar na história da cultura escolar, tal ideia não se confirma. É possível apreender, ao longo da história da escola, diversas inserções, exclusões, alterações, rupturas e, ao mesmo tempo, permanências. E estas, como Gallego (2016, p. 5) assevera, "nem sempre guardam os sentidos da sua inclusão no contexto escolar já que interagem com novos processos, novos objetos etc.". Portanto, ao se pensar nos cadernos escolares, não é possível afirmar que esse objeto é o mesmo de antes, nem em relação à materialidade e nem ao uso. Do mesmo modo, ao se levar em conta as tecnologias digitais e a sua inserção na educação, muito provavelmente, implicar-se-á em mudanças nas formas de se relacionar com o conhecimento e, por isso, em aprender. 
Dominique Julia, historiador francês, concebe a cultura escolar como um conjunto de práticas e normas que definem conhecimentos e condutas, sendo preciso compreender as relações conflituosas que ela mantém, a cada período de sua história, com o conjunto de culturas que lhe são contemporâneas. Julia (2001, p. 10-11) forja a cultura escolar como

[...] um conjunto de normas que definem conhecimentos a ensinar e condutas a inculcar, e um conjunto de práticas que permitem a transmissão desses conhecimentos e a incorporação desses comportamentos; normas e práticas coordenadas a finalidades que podem variar segundo as épocas (finalidades religiosas, sociopolíticas ou simplesmente de socialização) [...] É conveniente compreender também, quando isso é possível, as culturas infantis (no sentido antropológico do termo), que se desenvolvem nos pátios de recreio e o afastamento que apresentam em relação às culturas familiares.

Nessa perspectiva, Julia evidencia que a cultura escolar está condicionada a um panorama maior, em que os aspectos sociais, políticos e econômicos estão relacionados, como já apontado na discussão do octógono das dimensões relativas aos suportes de escrita. Assim, não se pode deixar de ter em mente que, da mesma maneira em que a produção de papel foi um marco para a escola, a produção dos computadores e dos tablets reverberam no ambiente escolar, fazendo com que esses aparelhos também tenham suas entradas nas instituições de ensino.

Tendo como base as ideias de Julia, as normas e as práticas desempenham um papel relevante na constituição da cultura escolar. Segundo Vidal (2005), essa abordagem é complementar à visão de Chervel (1990), o qual acredita que a escola produz uma cultura original, singular e específica. Assim, torna-se fundamental pensar nos cadernos escolares e na cultura escolar no contexto específico das tecnologias digitais nas escolas, posto que há aspectos normativos, mas que não acontecem na prática e, ao mesmo tempo, há elementos que não estão previstos, mas que são percebidos nas ações pedagógicas.

Além disso, o conceito de cultura escolar também dialoga com o de forma escolar (VINCENT, 1980), que, consoante Vidal (2005), compõe os estudos das estruturas invariantes da escola. Isto é, interessado em compreender as permanências na organização escolar, Vincent se debruçava sobre a gênese do espaço, do tempo e da relação pedagógica, três elementos que, para ele, constituíam a instituição escolar. De acordo com Vincent, Lahire e Thin (2001), o aparecimento da forma escolar acontece em meio a conflitos, desafios, lutas, de modo que na história da escola também se encontram polêmicas; por conseguinte, o ensino encontra-se, frequentemente, "em crise". Assim, conforme os autores, a teoria da forma escolar possibilita pensar a mudança, diferentemente do que ocorre com as teorias estruturalistas. 
Outrossim, dentro de uma mesma escola, portanto, em tese, inserido na mesma cultura escolar, há diferentes perspectivas, como já evidenciado na discussão do octógono das dimensões relativas aos suportes de escrita. Por exemplo: alguns professores consideram que os alunos devam fazer registros autorais em seus cadernos; outros, porém, acreditam que os alunos devam copiar tudo o que está na lousa e atribuem nota para isso; há também os que liberam o uso de aparelhos tecnológicos para registros, assim como existe quem regule ou proíba essa utilização. Nessa mesma linha, alguns alunos apontam que devem anotar aquilo que não compreenderam, ao passo que outros consideram anotar só aquilo que entendem da aula; há, ainda os que registram suas dúvidas, enquanto outros querem anotar tudo o que é dito durante a aula. Igualmente, certos estudantes preferem fazer suas anotações em cadernos digitais, outros, porém, preferem fazê-lo no papel; outros ainda, alternam, fazendo registros ora em um suporte, ora em outro a depender do componente curricular.

Nesse ponto, faz-se necessário trazer à tona as dimensões temporais e de contexto tratadas no octógono, para evidenciar a linha histórica que se inicia nos cadernos e chega mais recentemente até os tablets. Durante esse processo, há um tempo em que diferentes materiais coexistem e são ressignificados. E à medida em que alguns suportes de escrita vão surgindo na escola, outros caem em desuso. Isso, no entanto, não acontece de maneira linear, homogênea e igual, visto que, como Chartier já afirmava em 1999 com relação à imprensa, "há portanto uma continuidade muito forte entre a cultura do manuscrito e a cultura do impresso, embora durante muito tempo se tenha acreditado numa ruptura total entre uma e outra" (p. 9).

Para traçar uma linha histórica e refletir sobre os usos dos cadernos na França enquanto a prática escrita se consolidava na escola, Anne-Marie Chartier (2007) reserva um capítulo de seu livro Práticas de Leitura e Escrita - história e atualidade. Nesse sentido, considera-se importante delinear um pequeno histórico em busca de compreender como os cadernos escolares apareceram entre os instrumentos de trabalho do aluno. Para tanto, usar-se-á como base, primeiramente, o texto Exercícios escritos e cadernos de alunos: reflexões sobre práticas de longa duração, de Anne-Marie Chartier (2007), em que é traçada a trajetória dos cadernos e da escrita na França desde o século XVIII. Também será uma importante referência o texto de Rogério Fernandes, Um marco no território da criança: o caderno escolar, de 2008, que tem como propósito estudar as funções e os papéis que estavam destinados aos cadernos, principalmente os de exercícios, nos diferentes estágios do processo formativo português. Outra importante fonte sobre a contextualização histórica dos cadernos é o texto de Jean Hébrard, de 2001, intitulado Por uma Bibliografia Material das Escritas Ordinárias: o espaço gráfico do caderno escolar (França -Séculos XIX e XX). 
De acordo com Hébrard (2001), algumas congregações cristãs da França notaram que o oferecimento da escrita se constituía em um dos meios mais eficazes para levar à escola e, consequentemente, ao catecismo, às crianças dos meios populares urbanos. Após a revolução pretendeu-se alfabetizar a população camponesa, ainda imersa em uma cultura que privilegiava a oralidade, com base nas ideias liberais e filantrópicas. O que se buscava com a alfabetização não era somente a formação religiosa, como também se pretendia evitar rumores, temores e revoltas camponesas. "Instruindo, a escrita pode erradicar as antigas culturas camponesas e abrir o espaço rural francês para a modernidade e a paz social.” (HÉBRARD, 2001, p. 116).

Era uma época em que escrever era dispendioso, uma vez que além de ter aprendido a escrever, o preço do papel era caro e a pluma de ganso era difícil de ser cortada. Portanto, aprender a escrever exigia tempo e dinheiro. No início do século XIX, de acordo com Hébrard (2001), a escrita deixa de se restringir às corporações especializadas dos mestres de escrita e aritmética, em que somente os alunos com boas condições financeiras faziam parte. Em 1833, segundo o autor, a oferta da escola já se configurava como suficientemente generalizada, de modo que cada município deveria abrir, no mínimo, uma escola para meninos. Nas palavras do pesquisador,

[...] mesmo que a França tenha conhecido, desde o século XVIII, uma escola centrada no ler-escrever e no contar, foi somente a partir das grandes reformas escolares da primeira metade do século XIX que esse novo trivium se torna instrumento essencial de uma educação do povo urbano ou rural pela escola. (HÉBRARD, 2001, p. 117).

No entanto, como o próprio autor ressalta, não foi suficiente para tornar possível a difusão da escrita, haver a demanda e a vontade de oferta. É necessário haver professores que sejam capazes de ensiná-la. Além disso, também era preciso instrumentos que permitissem essa aprendizagem, que durante muito tempo, foi artesanal na relação entre mestre e aprendiz, tais eram "o papel da ardósia e do quadro negro para os iniciantes; ou do caderno para os que já têm a mão mais treinada" (HÉBRARD, 2001, p. 117). Sendo assim, o caderno é um objeto comum da vida escolar do estudante desde o século XVI.

O Ratio Studiorum refere-se a esse objeto como "livro branco" e propõe usá-lo em alternância com o livro impresso. A partir do século seguinte, XVII, ele torna-se um suporte obrigatório para a obra prima caligráfica (HÉBRARD, 2001). Contudo, os cadernos não aparecem na maior parte das vezes nas pequenas escolas até o século XIX.

Hébrard (2001) afirma que é no primeiro terço do século XIX que ocorre a generalização do caderno na escola primária, marcando assim, um importante acontecimento na evolução da alfabetização escolar. Mais adiante assegura que “É somente a partir de 1860 quando sua prática 
é verdadeiramente corrente, que nós encontramos um corpus suficiente de cadernos nas coleções conservadas." (HÉBRARD, 2001, p. 119).

Segundo Chartier (2007), em torno dos anos 1850, as autoridades escolares propuseram uma nova modalidade de exercícios, diferente da retórica e do latim. Os exercícios eram chamados de "redação de estilo" ou ainda de "composição francês", que se tratavam, na verdade, das redações. No século seguinte, esses exercícios passaram a ser chamados de "expressão escrita" e, mais tarde, de "produção de texto". Chartier alerta que o que permite datar um texto é sua aparência, uma vez que por volta de 1968, a caneta esferográfica passou a ser um material integrante dos estojos dos alunos, e então, os professores não puderam ensinar a escrita da mesma forma. Assim, a escrita escolar deixou de ser a mera imitação da leitura para tornar-se uma escrita apoiada nas leituras.

Deste modo, para Chartier, é importante para quem estuda as aprendizagens escolares se preocupar com as condições materiais de realização, já que "os suportes de escrita definem atitudes, tanto na recepção quanto na produção, impõe limites, restringem ou alargam os usos possíveis que, no caso dos escritos escolares, concernem tanto ao trabalho dos alunos quanto ao dos professores" (2007, p. 46).

Hébrard (2001) afirma que no período entre 1860 e 1960, os cadernos se constituíam em um "suporte de uma prática de escrita que poderia ser a matriz de uma alfabetização escolar específica, a que leva a França rural a entrar definitivamente em uma cultura 'moderna' do escrito" (p. 120). O autor revela que nem sempre a aprendizagem da escrita e da leitura aconteceu por meio do caderno, uma vez que também foram encontrados vestígios de escritas em outros e diferentes suportes: papiros no Egito; tabletes de argila na Mesopotâmia; cacos de vasilhames na Grécia; tábuas de madeira cobertas de cera na antiguidade greco-romana; areia fina e mais tarde, no século XVIII, a ardósia. É a partir da metade do século XIX que os cadernos passam a ocupar uma grande parcela do trabalho escolar.

Chartier (2007) assinala que, na época do Antigo Regime da França, os alunos compunham ao longo do ano tanto no âmbito doméstico, quanto no profissional os "livros de razão" e os "livros de contas". Esses cadernos eram formados por folhetos reunidos e encadernados e eram escritos com pena de ganso ou com lápis. O material mostrava dois lados da atividade escolar: o primeiro uso que aconteceu próximo às duas primeiras décadas dos anos 1800 era o livro como um modelo contendo uma disposição impecável da página. O segundo modo de utilização, por sua vez, era o de rascunho de trabalho, em outras palavras, era a escrita de primeiro impulso que aconteceu próximo a 1836. É a partir destes dois modelos de anotações (livro e rascunho) que vai se constituir o caderno do dia da escola primária. 
Hébrard (2001, p. 121-122) aponta outros tipos e usos dos cadernos:

Cadernos de deveres (deveres da escola e deveres de casa, separados ou juntados), cadernos reservados a uma disciplina particular (escrita para as classes dos primeiros anos escolares, história, geografia, lições de coisas, redações para alunos maiores), mais raramente cadernos de correções de deveres, constituem o essencial do fundo. É preciso acrescentar, a partir dos últimos anos do século XIX, os 'cadernos de rodízio' (mantidos a cada dia por uma criança diferente) e, os que foram conservados mais tardiamente, os 'cadernos de provas mensais' destinados a avaliação contínua do aluno ao longo de toda a sua escolaridade.

O autor também afirma que nos cadernos analisados, a atividade mais recorrente é o ditado, com exceção dos primeiros anos escolares, em que o exercício de escrita aparece majoritariamente, seguido dos exercícios de análise gramatical e/ou sintática e dos exercícios de vocabulário. A segunda atividade mais frequente é o problema de aritmética. Todavia, nos inúmeros e diferentes exercícios se apresentam a preocupação com a educação moral das crianças. De acordo com o autor, há uma "duplicação permanente das finalidades de cada prática escolar: tudo serve para tudo e nada se perde!” (HÉBRARD, 2001, p. 124).

Segundo Chartier (2007), os cadernos passam a fazer parte do cotidiano da escola primária quando um dos conteúdos da escola passa a ser os "elementos da língua francesa" próximo aos anos 1830. Outro fator que facilitou a expansão dos usos do caderno foi a redução de preços ocasionada graças a produção industrial de celulose. Além disso, alargou-se também o uso da pena metálica, mais prática e resistente do que a pena de ganso. No mesmo período houve mudanças no mobiliário escolar: os alunos passaram a ter uma carteira pessoal com espaço para colocar seus livros e cadernos e um tinteiro.

Neste contexto, os cadernos passaram por diversas transformações. Com a mudança de mobiliário, esse material foi dividido de acordo com as disciplinas, o mesmo que acontecia nas escolas secundárias. Contudo, essa divisão era condenável, uma vez que tornava mais árduo o trabalho do professor que tinha que dar conta de diversos cadernos por aluno. A partir daí, instala-se um segundo modelo, que consistia num único caderno, chamado de "caderno do dia" que apresentava diversas utilidades: servia para vigiar o trabalho dos alunos e dos professores e comparava os alunos e suas notas. Pode-se perceber, portanto, que a finalidade do caderno muda, visto que ele, neste momento, prestava conta das atividades e não era apenas uma compilação de textos ou seleção de modelos de letras. Nas palavras de Hébrard (2001, p. 135),

ter vários cadernos na escola primária, um para cada matéria, é macaquear um pouco o ginásio, mas é, sobretudo dispersar a atenção, tanto a do aluno como a do professor, ou mais ainda das pessoas encarregadas da supervisão do trabalho dos dois protagonistas da escolarização: a família, para o aluno, e o inspetor, para o professor. 
De acordo com Fernandes (2008, p. 51, grifos do autor), "a palavra caderno ou quaderno significava quatro ou cinco folhas de papel cosidas umas com as outras. Essas folhas andavam reunidas numa pasta, em maços diferenciados, formando o que se chamava um 'bandameco' (vade-mécum)”. Além disso, tudo indica que o mercado dos materiais didáticos, inclusive os cadernos, acontecia nas escolas ou com os mestres.

O mesmo autor assegura que, desde 1722, data da edição dedicada a D. João V da Nova escola para aprender a ler, escrever e contar de autoria de Manuel Andrade Figueiredo, aparecem referências aos cadernos, o que sugere que sua existência data de um período anterior. Contudo, pode-se imaginar que um número não muito grande de alunos tinha condições de comprar e utilizar o material. Assim, a difusão da escola do povo, explica a procura de novos métodos para buscar soluções capazes de baixar os custos do ensino. Eis o objetivo do sistema de ensino mútuo ou também chamado método lancasteriano ${ }^{25}$.

Um dos objetivos essenciais do ensino mútuo estava relacionado à escolarização dos filhos das classes populares. Desse modo, a fim de baratear os custos com o ensino, o papel deixa de ser o material preferencial, contrariando os calígrafos, e a preferência passa a ser de dois equipamentos menosprezados até então: a areia e a lousa de ardósia. A lousa substituiu ou coexistiu o caderno durante muito tempo, isso porque elas tinham uma duração indefinida, tornando-se assim muito mais econômica, além de ser um caderno com várias funções, uma vez que servia tanto para o ensino da escrita como para os exercícios de aritmética.

Hébrard (2001) também notou a grande preocupação com a organização das páginas e das letras nos cadernos no século XIX. Ele afirma que

[...] os exercícios não são inscritos apenas com letras bem traçadas; estas são dispostas sobre a página segundo cânones relativamente estáveis. Os parágrafos são separados por traços de diversas larguras; as margens são organizadas e desenham espaços complexos e perfeitamente regrados; os títulos são hierarquizados com todas as sutilezas da arte de sublinhar com um ou vários traços. (p. 125).

Ademais, o autor assevera que, nesse período, a cópia se apresentava como o centro da alfabetização, na medida em que esta se propunha a ensinar, a ler e a escrever. Em suas pesquisas, ele verificou que o "passar a limpo" também se constituía em importante atividade,

\footnotetext{
${ }^{25}$ O método mútuo ou também chamado método lancasteriano tinha como principal intenção otimizar o tempo de ensino dadas as necessidades daquele momento histórico e diminuir os custos do ensino. Essa prática era proveniente das classes jesuíticas e reaparece no século XIX nos meios operários ingleses sob a idealização de Joseph Lancaster (1778-1838). Para seus idealizadores, o método impunha uma organização que evocava maior rigor que o método simultâneo, pois era baseado em horários minuciosos, nos quais havia uma rigorosoa fragmentação do tempoprevia muitos alunos em uma mesma sala, a segmentação detalhada da aprendizagem, a sucessão minuciosa das atividades, a recomposição permanente de oito grupos de nível segundo a progressão individual dos alunos. Além disso, para economizar professores, o método previa o uso de um decurião, isto é, um aluno mais adiantado (a ideia de monitores) que deveria mediar a relação entre dez alunos e o mestre.
} 
visto que não havia erros e tampouco rasuras. Nesse tempo em que a escrita era de difícil acesso, em especial, no meio rural, os cadernos visavam o livro, já que o professor entendia que o caderno poderia ser o único "livro" que o aluno poderá consultar e guardar durante sua escolarização. Portanto, de acordo com o pesquisador, o caderno se esmera em imitar o livro (HÉBRARD, 2001, p. 127).

No início dos anos 1950, os cadernos não se restringiam às cópias em suas páginas. Hébrard (2001) afirma que nesse período os cadernos passam a conter fotografias, cartões postais, recortes de páginas de revista, listas e tabelas. Assim sendo, esse material não precisa mais substituir e imitar os livros, uma vez que eles passaram a ser disponibilizados gratuitamente aos alunos.

Os cadernos de caligrafia, mesmo com os altos custos, começaram a ter seu uso expandido por diversas razões: a primeira delas se deve ao fato de que mesmo com o invento da máquina de escrever, por não poder ser usada em todos os casos e devido a seu alto preço, foi ressuscitada uma prática corrente das escolas da capital de Portugal: a caligrafia. Outro motivo é que a letra caligrafada estava associada à letra da elite, sendo a caligrafia perfeita símbolo de distinção social; outro fator para a expansão do uso dos cadernos de caligrafia é que esses cadernos pretendiam utilizar o ensino dessa disciplina como base da transmissão das matérias básicas e da formação moral; e uma quarta razão é a associação entre os cadernos de caligrafia a métodos de leitura.

No Brasil, fazer uso dos cadernos de caligrafia, no entanto, implicava em regras posturais e corporais tanto destinadas a alunos, cujo objetivo era delinear a boa posição do aluno perante a escrita, quanto a professores, que deveriam vigiar constantemente a postura física de seus alunos. O estudante deveria dominar toda a postura corporal: saber como postar a cabeça, os cotovelos, os antebraços, o tronco, as pernas e os pés, de modo que o corpo deveria estar completamente voltado para frente da carteira, se aproximando desta, mas sem tocá-la. As pernas não deveriam estar cruzadas e os antebraços deveriam estar apoiados na carteira. A mão, por sua vez, deveria repousar sobre o papel e a cabeça não deveria ficar inclinada nem para a direita e nem para a esquerda, apenas um pouco para frente e manter, aproximadamente, trinta centímetros de distância da folha de escrita. Para as meninas ainda havia outra recomendação: elas deviam ter o cuidado de distribuir bem a saia de maneira igual nos dois lados.

Razzini (2008) complementa esses apontamentos trazidos por Fernandes (2008), afirmando que essas cobranças por posturas deram origem à chamada "higiene escolar", passível, até mesmo, de inspeção. Além da postura corporal, havia regras no modo de manipular a caneta: ela deveria ser segurada entre os três primeiros dedos, e recomendava-se que a tinta 
fosse da cor preta. Além disso, também era necessário ter um mobiliário adequado, com mesas e cadeiras adaptadas à altura do aluno.

Hébrard (2001) apresenta outro tipo de organização gráfica dos cadernos franceses que merece ser destacado: o fazer uma agenda. Nesse caso, é a ordem cronológica que organiza os registros. $\mathrm{O}$ autor afirma que rapidamente torna-se hábito a escrita da data no cabeçalho de cada página ou de uma série de exercícios, sendo que depois de 1914 cada dia de aula inicia-se pela escrita da data. Dessa forma, "habitua-se o aluno a pensar o tempo de um dia como uma sequência regular de tarefas, o tempo da semana como uma sequência regular de jornadas de trabalho" (HÉBRARD, 2001, p. 135). Isso quer dizer que além da finalidade descrita, o caderno-agenda guarda a função de controlar o que foi feito em sala de aula e mostrar o volume de um dia de trabalho.

O Decreto francês n. 6.137, de 29 de setembro de 1919 estabeleceu que todos os alunos, sem exceção, deveriam registrar em um caderno especial, chamado de "caderno individual" todos os exercícios escolares e, outro caderno, o denominado "caderno rotativo", em que, diariamente, um dos alunos resolveria todos os exercícios que fossem passados. De acordo com essa legislação, o caderno rotativo era obrigatório para a terceira e quarta série, e facultativo e recomendável para a primeira e segunda séries. Ademais, os "cadernos individuais" eram obrigatórios e de tempos em tempos deveriam ser destinados aos encarregados da educação, quem os rubricaria. Com o tempo, o caderno rotativo deixou de existir e todos os cadernos passaram a ser somente individuais. Da mesma forma, verificou-se o desaparecimento dos cadernos de caligrafia.

No contexto brasileiro, outros tipos de cadernos apareceram, como os cadernos impressos, os cadernos de atividades e os cadernos de deveres, entretanto, nota-se que o sentido que majoritariamente, hoje, atribui-se ao caderno e a forma como ele é utilizado na escola se aproxima do antigo caderno individual. Além da legislação apontada por Fernandes (2008), Chartier (2002) destaca outros fatores que possibilitaram a expansão do uso dos cadernos, como a produção industrial da celulose que fez com que os preços do papel caíssem e o uso da pena metálica, muito mais resistente e prática do que a pena de ganso. Cabe aqui assinalar que os cadernos escolares diários citados por Fernandes (2008) são contemporâneos do aparato de escrita metálico.

De acordo com os estudos de Razzini (2008), no Brasil, já no período republicano, houve o alargamento do método simultâneo, principalmente nas zonas urbanas, com a criação 
dos grupos escolares em $1893^{26}$. Com a reunião de várias escolas nos grupos escolares, ocorreu o aumento do número de alunos em um mesmo prédio, possibilitando a organização de turmas maiores - cerca de 40 alunos - e mais homogêneas, tanto em relação à idade e ao sexo, como também com o nível de aprendizagem, em cada sala de aula.

Dessa forma, como a referida pesquisadora relata, os grupos escolares renovaram o ensino simultâneo (o ensino a um grupo de alunos da mesma coisa ao mesmo tempo), que se opunha ao ensino individual. Além de adotar essa metodologia, a cidade de São Paulo também procurou adotar um método de aprendizagem simultânea da escrita e da leitura, e o método intuitivo $^{27}$, preconizados por Pestalozzi e Froebel. Esse último método era assim chamado porque dava grande importância à intuição e à observação dos objetos, da natureza, das coisas e dos fenômenos.

Além da adoção do método simultâneo, do modo intuitivo e da aprendizagem simultânea da leitura e da escrita, Razzini (2008) assevera que, no contexto brasileiro, houve cada vez mais o uso do papel para exercícios de escrita, como cópias, ditados e composições. Segundo a pesquisadora,

tal fato ocorre, porque, de um lado, os avanços tecnológicos haviam barateado a produção do papel com o aumento da velocidade da produção propiciada pela máquina a vapor e com a substituição da pasta de trapos pela pasta de madeira; e, de outro lado, porque a folha escrita se constituía como prova material do trabalho do professor e dos alunos mais adiantados (RAZZINI, 2008, p. 101).

Ao contrário, Fernandes (2008) acredita que a expansão dos novos instrumentos educativos, como os cadernos, foi ocasionada num momento posterior, quando ocorreu individualização do ensino, ou seja, quando o aluno passa a ser o centro do processo ensinoaprendizagem. Razzini (2008) afirma ainda que a substituição da lousa de ardósia pelo papel e algum tempo depois, pelo caderno, aconteceu de maneira gradativa, e muito mais irreversível, nas escolas urbanas. Mais especificamente em São Paulo, a mesma autora relata que o uso

\footnotetext{
${ }^{26}$ A criação dos grupos escolares (escolas graduadas cujo método de ensino é o simultâneo) em 1893 foi um marco da modernização escolar. Sobre a história dos grupos escolares em São Paulo, destacam-se as contribuições do trabalho de Rosa Fátima de Souza (1998). De acordo com a autora, "a superioridade organizacional e material dos grupos escolares fez com que fossem considerados estabelecimentos escolares arquetípicos do que melhor havia no ensino público primário" (SOUZA, 2004, p. 1). Os grupos escolares marcaram a história das instituições escolares por instaurarem mudanças significativas na estrutura pedagógica e administrativa da escola primária, especialmente no tocante à organização temporal, assim como demonstrado pelas pesquisas desenvolvidas por Gallego (2003, 2008). Em meados do século XX, os grupos escolares se constituíam na modalidade predominante da escola primária no Brasil, acompanhando o processo de urbanização e democratização do ensino público.

${ }^{27} \mathrm{O}$ método intuitivo parte da premissa de que toda a educação deve começar pela educação dos sentidos e se caracteriza por oferecer aos alunos dados sensíveis a observação, indo do pequeno para o grande, do particular para o geral, do concreto para o abstrato.
} 
intensivo do caderno se iniciou nos grupos escolares, sendo que já em 1908, o Annuario do ensino (p. 105), já recomendava que fossem usados diferentes tipos de cadernos para linguagem aritmética, caligrafia, desenho e cartografia. Segundo a autora,

A presença cada vez maior do caderno na escola elementar como principal suporte de escrita constituiu outra mudança substancial que incrementou não só a produção de cadernos, mas a produção dos instrumentos de escrita apropriados para o papel, como o lápis grafite e a pena metálica, barateando os produtos. (RAZZINI, 2008, p. 105).

Desse modo, de acordo com Razzini (2008) e Mignot (2008b) a abertura da escola para as classes populares criou demandas para a indústria. Nas palavras de Mignot (2008c, p. 69), “o ingresso cada vez maior de alunos nas escolas criou novas demandas para a indústria e o comércio de suportes e utensílios da escrita.". A mesma autora assinala que com as reformas escolanovistas (que pretendiam constituir um sistema público que visava atender integralmente os alunos), os materiais pedagógicos ganharam grande espaço e importância. Com ideias convergentes, Razzini (2008) afirma que a expansão da escola elementar, os professores e os alunos se tornaram um importante segmento de consumidores de materiais escolares.

Mignot (2008c) concluiu em sua pesquisa que a história da Casa Cruz, uma das mais antigas e maiores papelarias cariocas, se entrecruza com a história da educação, visto que o aumento do ingresso de alunos nas escolas implicou em demandas para a indústria e aumentou a venda de suportes de escrita. O sucesso na venda de cadernos escolares se deve ao barateamento do custo do papel e a ampliação da malha escolar. No entanto, mesmo com um número cada vez maior de alunos matriculados na escola e com o barateamento do custo do papel, Mignot (2008c) alerta que os cadernos, ao contrário do que muitos relatos sugerem, não haviam se tornado acessíveis a todos os alunos.

Nesse contexto, a Casa Cruz se consolidava como um espaço de memória da produção cardeneira do nosso país, na qual além de vender os produtos de outras empresas, passou a criar diversas coleções de cadernos. A autora constata que o sucesso comercial desse estabelecimento se devia, desde 1910, ao investimento em produtos diferenciados, para um público que sempre foi ávido por novidades

Esse investimento pesado em produtos diferenciados implicou na papelaria contratar capistas que "cuidavam de tornar o caderno um objeto desejável aos olhos dos consumidores" (MIGNOT, 2008c, p. 72). Isso se deve ao fato de que a ilustração da capa tinha como intuito veicular valores, como o ufanismo, deixando claro que os cadernos não se resumiam a um suporte de escrita destinado apenas à aprendizagem e aos exercícios de escrita, como também, por meio deles, deveriam transmitir valores a serem perpetuados. 
Assim, pode-se constatar que, como afirma Mignot (2008c), os cadernos "trazem as marcas dos processos de industrialização, afetados, quase sempre, pelas turbulências econômicas, políticas governamentais, incentivos fiscais e avanços tecnológicos.” (MIGNOT, 2008c, p. 80-81). Esses suportes de escrita, antes tão raros e caros, hoje são objetos banais, mas que ainda afetam as atividades de escrita e influenciam o ensino-aprendizagem, bem como o tempo escolar.

Nesses três séculos de existência, os cadernos escolares foram tendo suas funções redesenhadas diversas vezes. Assim como sua materialidade também foi definida e redefinida: são novos formatos, maior número de páginas, mais qualidade do papel, capas antes coladas, grampeadas ou ainda costuradas deram lugar à espiral, com páginas que podem ser facilmente arrancadas. Podemos encontrá-los à venda hoje em papelarias, lojas de conveniência, shoppings, mercados, banca de revistas, postos de gasolina, pela internet. Como afirma Mignot (2008c, p. 86): “Deixaram de ser objetos de desejo. Viraram objetos de consumo.”.

Tal efeito também pode ser verificado na entrada das tecnologias digitais na escola, há 30 anos esses equipamentos também eram raros e caros. Desse período para cá, também tiveram suas funções e usos remodelados, impactando modos de ensino e aprendizagem e, hoje, em muitas instituições deixaram de ser objeto de desejo, para tornarem-se objeto de consumo, ainda mais evidenciado pelo contexto da pandemia.

Há outro ponto de entrecruzamento da incorporação de cadernos e tablets nas escolas: a otimização do tempo escolar. Como já mencionado, os cadernos impactaram o tempo de uma forma escolar pautada no método simultâneo. Isso se reverbera até hoje, mas não é possível afirmar que seu uso permanece o mesmo desde então, visto que há modificações. O mesmo se pode inferir das tecnologias digitais, uma vez que o uso que se fazia nas escolas há 25 anos ou até mesmo há dez anos, não é o mesmo de hoje. A maneira como os materiais vão sendo usados, sofre modificações exatamente porque há outras formas escolares, e isso fica especialmente evidente no modelo de educação remota imposto pela pandemia. É preciso considerar que nesse contexto online há uma importante alteração da forma escolar, uma vez que os alunos não estão todos na escola, dentro de uma sala de aula, tendo aula ao mesmo tempo, fazendo seus registros no mesmo momento.

Faz-se relevante evocar as ideias de Agustín Escolano Benito (1999) que estuda a cultura escolar na história da educação espanhola, ressaltando aspectos temporais e espaciais. Em seus estudos realizados no fim da década de 1990, ele distingue três culturas da escola: a científica ou pedagógica (elaborada no âmbito da academia), a empírica (prática ou material, produzida pelos professores cotidianamente), e a política ou normativa (relativa ao conjunto de 
regras que fundamentam a organização escolar). Desse modo, para ele, a cultura escolar é produzida por diferentes instâncias. Ainda de acordo com Escolano, as culturas da escola se concretizam nas regras que orientam a prática de ensino, como a organização dos espaços e dos tempos, as regras disciplinares, as metodologias, os conteúdos dos programas e os exames.

Tal compreensão faz sentido quando se trata das tecnologias digitais na educação uma vez que, a pesquisa desenvolvida demonstrou o impacto dessas tecnologias na educação a nível científico baseado no que se pôde verificar da cultura empírica, aquela observada na instituição. Mas há ainda que se considerar a cultura política, ou seja, as regulamentações no plano normativo. Nesse contexto, é importante evidenciar o que os documentos oficiais tratam sobre o uso das tecnologias na educação.

\subsection{TECNOLOGIAS DIGITAIS NA EDUCAÇÃO: ENTRE OS DOCUMENTOS OFICIAIS E DADOS DA REALIDADE}

Conforme assinalado anteriormente, é importante elucidar como os documentos oficiais preveem e expressam o uso das tecnologias digitais nas escolas. $\mathrm{O}$ primeiro documento analisado foram as Diretrizes Curriculares Nacionais (DCN), publicado em 2013. Na seção Organização Curricular das DCN, faz-se o apontamento de que as Tecnologias da Informação e Comunicação (TIC) fazem parte de um contínuo desenvolvimento de tecnologias que vão desde os gizes até os livros, e que podem apoiar, enriquecer e potencializar as aprendizagens. Há também a indicação de que essas tecnologias de informação e comunicação

como qualquer ferramenta, devem ser usadas e adaptadas para servir a fins educacionais e como tecnologia assistiva; desenvolvidas de forma a possibilitar que a interatividade virtual se desenvolva de modo mais intenso, inclusive na produção de linguagens. Assim, a infraestrutura tecnológica, como apoio pedagógico às atividades escolares, deve também garantir acesso dos estudantes à biblioteca, ao rádio, à televisão, à internet aberta às possibilidades da convergência digital. (BRASIL, 2013, p. 25).

No documento aborda-se que os estudantes nasceram na era digital, enquanto os docentes apenas creem que acompanham a essa era. De acordo com o que está expresso, essa distância precisa ser superada de maneira que haja a aproximação dos recursos de tecnologia de informação e comunicação e a criação de novos métodos didático-pedagógicos, a fim de que estejam inseridos no cotidiano escolar, uma vez que "já que o domínio e compreensão das mesmas são considerados como uma das principais condições para o exercício da cidadania na contemporaneidade" (BRASIL, 2013, p. 26). 
Assim, as DCN preveem que as tecnologias digitais estejam presentes no cotidiano escolar, tanto para professores, quanto para alunos, desde o início da Educação Básica de maneira transversal, recomendando a utilização de mídias e tecnologias educacionais, como processo de dinamização dos ambientes de aprendizagem e a oferta de atividades de estudo utilizando tecnologias de comunicação.

Organicamente articuladas, a base comum nacional e a parte diversificada são organizadas e geridas de tal modo que também as tecnologias de informação e comunicação perpassem transversalmente a proposta curricular desde a Educação Infantil até o Ensino Médio, imprimindo direção aos projetos político-pedagógicos. (BRASIL, 2013, p. 33).

Nesse sentido, o documento alerta para a necessidade de oferta de formação adequada para o uso das TIC para os professores, bem como a provisão de recursos midiáticos atualizados e em número suficiente para os estudantes, visando a utilização qualificada das tecnologias e dos conteúdos das mídias, a fim de que a escola cumpra o importante papel de inclusão digital e de utilização crítica das tecnologias da informação e comunicação.

Outro documento analisado foi a Base Nacional Comum Curricular, publicada em 2017. Ela tem pontos convergentes com as DCN e é um documento mandatório que tem como objetivo orientar a construção dos currículos com a proposta de discutir e promover a equidade a nível federal, isto é, garantir os mesmos direitos para cada criança no Brasil. Nela está expresso que ao longo de toda a Educação Básica devem ocorrer aprendizagens essenciais que asseguram aos estudantes o desenvolvimento de dez competências gerais.

No documento competência é definido como "a mobilização de conhecimentos (conceitos e procedimentos), habilidades (práticas, cognitivas e socioemocionais), atitudes e valores para resolver demandas complexas da vida cotidiana, do pleno exercício da cidadania e do mundo do trabalho." (BRASIL, 2018, p. 8). Entende-se que a tecnologia assume um papel relevante na Base, uma vez que das dez competências gerais contidas no documento, três envolvem a questão das tecnologias digitais:

1. Valorizar e utilizar os conhecimentos historicamente construídos sobre o mundo físico, social, cultural e digital para entender e explicar a realidade, continuar aprendendo e colaborar para a construção de uma sociedade justa, democrática e inclusiva.

2. Exercitar a curiosidade intelectual e recorrer à abordagem própria das ciências, incluindo a investigação, a reflexão, a análise crítica, a imaginação e a criatividade, para investigar causas, elaborar e testar hipóteses, formular e resolver problemas e criar soluções (inclusive tecnológicas) com base nos conhecimentos das diferentes áreas.

[...]

4. Utilizar diferentes linguagens - verbal (oral ou visual-motora, como Libras, e escrita), corporal, visual, sonora e digital -, bem como conhecimentos das linguagens artística, matemática e científica, para se 
expressar e partilhar informações, experiências, ideias e sentimentos em diferentes contextos e produzir sentidos que levem ao entendimento mútuo. (BRASIL, 2018, p. 9, grifos nossos).

Ou seja, está explícita a importância de valorizar e utilizar conhecimentos historicamente construídos acerca das tecnologias, de desenvolver o pensamento científico criando soluções, até mesmo tecnológicas, e de utilizar a linguagem digital para se expressar. Além dessas, há uma competência que trata exclusivamente das tecnologias digitais:

5. Compreender, utilizar e criar tecnologias digitais de informação e comunicação de forma crítica, significativa, reflexiva e ética nas diversas práticas sociais (incluindo as escolares) para se comunicar, acessar e disseminar informações, produzir conhecimentos, resolver problemas e exercer protagonismo e autoria na vida pessoal e coletiva. (BRASIL, 2018, p. 9).

Além de constar nas competências gerais, a tecnologia também é citada na lista de decisões a serem tomadas para adequar a BNCC à realidade local considerando o contexto, as características dos alunos e a autonomia dos sistemas e das redes de ensino. Essas decisões precisam ser consideradas na organização dos currículos, os adequando às diferentes modalidades de ensino - Educação Especial, Educação à Distância, Educação de Jovens e Adultos, Educação do Campo, Educação Escolar Indígena, Educação Escolar Quilombola. Dentre as decisões apresentadas, há uma que se relaciona às tecnologias digitais: "Selecionar, produzir, aplicar e avaliar recursos didáticos e tecnológicos para apoiar o processo de ensinar e aprender" (BRASIL, 2018, p. 17).

Para além disso, a tecnologia também é mencionada nos Direitos de aprendizagem e desenvolvimento da Educação Infantil e nas Competências específicas de área nos Ensinos Fundamental e Médio, bem como aparecem nos respectivos Objetivos de aprendizagem e desenvolvimento de habilidades. De maneira breve, o objetivo de a tecnologia ser trabalhada na Educação Infantil é estimular o pensamento criativo, lógico, crítico, o desenvolvimento motor, a linguagem e a curiosidade. Na outra ponta, no Ensino Médio, tem-se a expectativa de que o estudante tenha um papel proativo no uso das tecnologias, bem como em seu processo de aprendizagem.

Já no Ensino Fundamental, etapa em que foram coletados os dados desta pesquisa, os alunos devem ser orientados por seus professores para usufruírem da tecnologia de maneira responsável, consciente e crítica na sala de aula, mas também nas situações cotidianas. No que se refere aos anos finais desta etapa de ensino, a BNCC traz uma preocupação acerca do que chama de cultura digital:

Há que se considerar, ainda, que a cultura digital tem promovido mudanças sociais significativas nas sociedades contemporâneas. Em decorrência do 
avanço e da multiplicação das tecnologias de informação e comunicação e do crescente acesso a elas pela maior disponibilidade de computadores, telefones celulares, tablets e afins, os estudantes estão dinamicamente inseridos nessa cultura, não somente como consumidores. Os jovens têm se engajado cada vez mais como protagonistas da cultura digital, envolvendo-se diretamente em novas formas de interação multimidiática e multimodal e de atuação social em rede, que se realizam de modo cada vez mais ágil. Por sua vez, essa cultura também apresenta forte apelo emocional e induz ao imediatismo de respostas e à efemeridade das informações, privilegiando análises superficiais e o uso de imagens e formas de expressão mais sintéticas, diferentes dos modos de dizer e argumentar característicos da vida escolar. (BRASIL, 2018, p. 61).

Dessa forma, verifica-se que a cultura digital é um dos pilares do documento, devendo ser inserida no processo de ensino e aprendizagem. Ademais, a BNCC contempla tanto o desenvolvimento de competências e habilidades relacionadas ao uso responsável e crítico das tecnologias digitais de maneira transversal, ou seja, presentes em todas as áreas do conhecimento, quanto de forma mais direcionada, isto é, tendo como finalidade o desenvolvimento de competências relacionadas ao próprio uso das tecnologias, linguagens digitais e recursos, conforme consta na quinta competência. Sendo assim, a tecnologia se mostra importante nesse documento, devendo ser compreendida e utilizada nas salas de aula do país.

Por fim, também se considerou relevante verificar o que o Currículo da cidade de São Paulo trata acerca das tecnologias. Este é um documento prescritivo, que contém sequências de diferentes tamanhos e durações, e aulas em que se afirma ter como princípios nos objetivos e metodologias a equidade, a inclusão e a educação integral. Nele, está expresso que o uso das tecnologias está a favor da aprendizagem, visando que os alunos não só saibam usá-las, mas que entendam como utilizá-las, com o objetivo de

interagir, conectar-se com o outro, participar e formar redes, colaborar, agir, responsabilizar-se, construir e ressignificar conhecimentos a partir delas, na perspectiva de sujeito integral em todas as suas dimensões, que conhece, investiga e expressa o mundo. (SÃO PAULO, [2019?], online).

Assim, "Tecnologias de Aprendizagem" aparece como um componente curricular do currículo da cidade e está dividido em três eixos:

1- Programação, que aborda a compreensão do desenvolvimento da linguagem de programação e a lógica do pensamento computacional como possibilidades de expressão e participação na sociedade.

2- Letramento Digital, que trata da interação ética, crítica e responsável nos meios tecnológicos, abrangendo as práticas sociais.

3- Tecnologias de Informação e Comunicação, que se refere à utilização dos recursos digitais disponíveis com o propósito de informar e comunicar socialmente. 
Diante do que foi exposto, percebe-se que o uso das tecnologias está previsto de maneira privilegiada e cara nos três documentos oficiais. Seu uso está previsto de maneira transversal como um meio para aprendizagens de todos os componentes curriculares, mas também com a preocupação de inserir os estudantes no meio digital, os ensinando como utilizar as tecnologias, a fim de democratizar o acesso e que o uso seja potente para suas vidas.

Todavia, não basta estar expresso no plano normativo, é necessário avaliar o acesso às tecnologias, questão essa que ficou destacada no contexto pandêmico, uma vez que milhares de alunos tiveram seu acesso rompido com a escola, porque não tinham como se conectar a ela. Para além dos dados de acesso e utilização das tecnologias digitais no país como um todo, há dados relevantes sobre o uso dessas tecnologias na educação e em instituições de ensino, coletados e publicados pelo Centro Regional de Estudos para o Desenvolvimento da Sociedade da Informação ${ }^{29}$ (Cetic.br). O Cetic.br, criado em 2005 com a missão de monitorar a adoção das tecnologias digitais, especialmente no que diz respeito ao acesso e uso de computadores, internet e dispositivos móveis, realiza pesquisas anuais. A coleta de dados da pesquisa mais recente foi realizada entre foi realizada entre os meses de agosto e novembro 2019, meses antes do início da pandemia, e publicada em 2020, de maneira que a análise permitiu compreender as condições das escolas e as dificuldades apresentadas na adaptação ao ensino remoto mediado pelas tecnologias digitais.

\subsubsection{Dados gerais de acesso às tecnologias digitais}

Com base dos dados publicados pelo Cetic.br, é possível ver uma alteração significativa em relação aos laboratórios de informática ou salas específicas equipadas com computadores.

\footnotetext{
${ }^{29}$ Segundo o Comitê Gestor da Internet no Brasil (2019, p. 23), desde 2005, “o Centro Regional de Estudos para o Desenvolvimento da Sociedade da Informação (Cetic.br) vem produzindo indicadores sobre o uso e a apropriação das tecnologias de informação e comunicação (TIC), com a disseminação de dados fundamentais para a tomada de decisões, seja por parte do governo, das empresas, da academia ou da sociedade em geral. Os estudos do Cetic.br têm contribuído de maneira relevante para a elaboração de políticas públicas de inclusão digital, bem como para o fortalecimento da economia digital. Atuando como centro regional de Categoria II da Organização das Nações Unidas para a Educação, a Ciência e a Cultura (Unesco) desde 2012, o Cetic.br também apoia iniciativas que contribuem para qualificar e fortalecer a comparabilidade de estatísticas produzidas em países da América Latina e nações lusófonas da África. No período recente, o trabalho do Cetic.br foi decisivo para a aprovação, pela Unesco, em novembro de 2018, dos Indicadores de Universalidade da Internet, um marco de referência para avaliar internacionalmente o desenvolvimento do ecossistema de Internet. Além de estimular a consulta aos indicadores pelos atores relevantes no plano regional, o Cetic.br foi responsável pela implementação do piloto da metodologia no Brasil, o que reforçou o papel estratégico do país em assuntos relacionados ao desenvolvimento da Internet e fez com que outras nações passassem a se empenhar na implementação desses levantamentos.”. Desde 2010, o Cetic.br realiza entrevistas com diretores, coordenadores pedagógicos, professores e alunos para mapear o acesso, uso e apropriação das tecnologias de informação e comunicação em escolas da educação básica (CENTRO REGIONAL DE ESTUDOS PARA O DESENVOLVIMENTO DA SOCIEDADE DA INFORMAÇÃO, [20--]).
} 
Em 2010, ano em que foi realizado a primeira coleta de dados do TIC Educação, havia uma perspectiva da política educacional que seguia a tendência dos anos 1990 em busca, justamente, da informatização das salas específicas. No entanto, verifica-se uma diminuição na existência de laboratórios nas escolas, uma vez que enquanto em 2015, eles estavam presentes em $83 \%$ das escolas públicas das áreas urbanas, em 2019, essa porcentagem passa para $67 \%$ sendo destes $56 \%$ em escolas municipais e $81 \%$ em instituições estaduais. Nas escolas privadas, percebe-se essa mesma tendência de queda no número de escolas com laboratórios ou salas especializadas, tendo apenas $54 \%$ das instituições que contavam com esse espaço no ano em que a coleta de dados foi realizada. Para além das mudanças nos processos de ensino e aprendizagem, a falta de manutenção dos equipamentos, a ampliação do acesso às tecnologias móveis e ao Wi-Fi também foram alguns dos aspectos que contribuíram para a diminuição desses espaços nas escolas, segundo a pesquisa.

Conforme a publicação do Cetic.br e o que os alunos ouvidos na pesquisa de Iniciação Científica já apontavam, o desafio da implementação dos laboratórios de informática é o de tornar seu uso efetivo. Em 2019, somente 67\% de escolas públicas urbanas mantinham seus laboratórios, e em menos da metade delas (48\%), eles estavam em uso. Outro dado importante diz respeito à disponibilidade de dispositivos para uso dos alunos nos momentos de atividades. A pesquisa mostrou que $26 \%$ das escolas localizadas em áreas urbanas não possuíam nenhum tipo de computador disponível para os estudantes, seja de mesa, portátil ou tablet, essa proporção fica ainda maior quando se analisa os dados por regiões, sendo $49 \%$ no Norte e $34 \%$ no Nordeste.

Apesar de, em 2019, somente 11\% das escolas públicas urbanas tinham mais de seis computadores portáteis e 7\% disporem de mais de seis tablets para uso dos alunos, quando se compara ao longo do tempo houve um aumento na presença de dispositivos móveis. Em 2013, $34 \%$ das instituições públicas urbanas possuíam até cinco computadores e, em 2019, essa porcentagem passa a ser 78\%. Algo semelhante se observa com os tablets. Em 2013, apenas $1 \%$ das escolas tinham até cinco destes equipamentos e no ano em que a pesquisa foi realizada, essa proporção passou a ser $12 \%$. Conforme, revela-se no Gráfico 1, o número inadequado de equipamentos é o motivo mais mencionado pelos professores quando se tratava das limitações e barreiras no uso das tecnologias digitais nas escolas públicas urbanas. 
Gráfico 1 - Professores de escolas públicas urbanas, por percepção sobre barreiras para o uso das TIC na escola (2019)

Total de professores que lecionam em escolas públicas urbanas(\%)

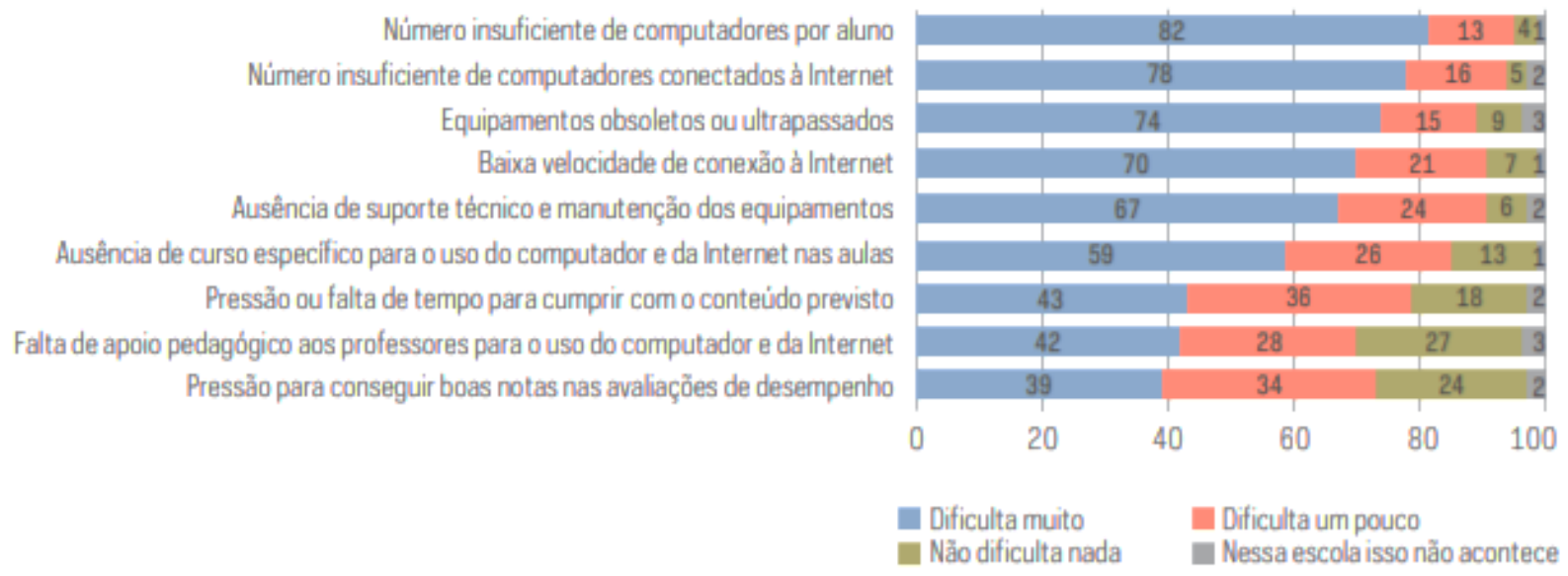

Fonte: Comitê Gestor da Internet no Brasil (2020, p. 27).

De acordo com os resultados da TIC Educação 2019, o acesso à rede está praticamente universalizado nas escolas urbanas, visto que, $99 \%$ das escolas públicas e particulares em zonas urbanas possuíam, pelo menos, um computador com acesso à Internet e, em 92\% delas, também havia a presença de rede WiFi. Há, porém outro indicador importante a ser considerado: o local da escola em que há disponibilidade de acesso à rede, visto que em apenas $34 \%$ das escolas públicas o acesso à rede WiFi estava disponível para os alunos, enquanto nas escolas particulares esse percentual era de $49 \%$, ou seja, ainda que praticamente todas as escolas de áreas urbanas contem com a rede móvel para se conectar, em menos da metade está disponível para acesso dos alunos. Analisou-se ainda que, em 2019, a Internet estava disponível dentro das salas de aula de $63 \%$ das escolas públicas urbanas, ou sejam quase dois terços dessas instituições. Em 2018, essa proporção era menor, 57\% das instituições públicas possuíam acesso à Internet na sala de aula. Segundo a publicação deste ano isso se devia ao fato de que com a baixa qualidade não é possível o acesso simultâneo a rede para as equipes administrativas, pedagógicas e para os alunos. Na maior parte dos casos, observou-se que a conexão estava voltada para as áreas administrativas da escola, como é possível verificar no Gráfico 2, a seguir. Vale ressaltar que os sistemas administrativos das escolas são em grande parte em rede, assim se faz necessário ter a conexão à Internet. 
Gráfico 2 - Locais da escola com acesso à Internet, em escolas urbanas (2015-2018)

Total de escolas localizadas em áreas urbanas com acesso à Internet (\%)

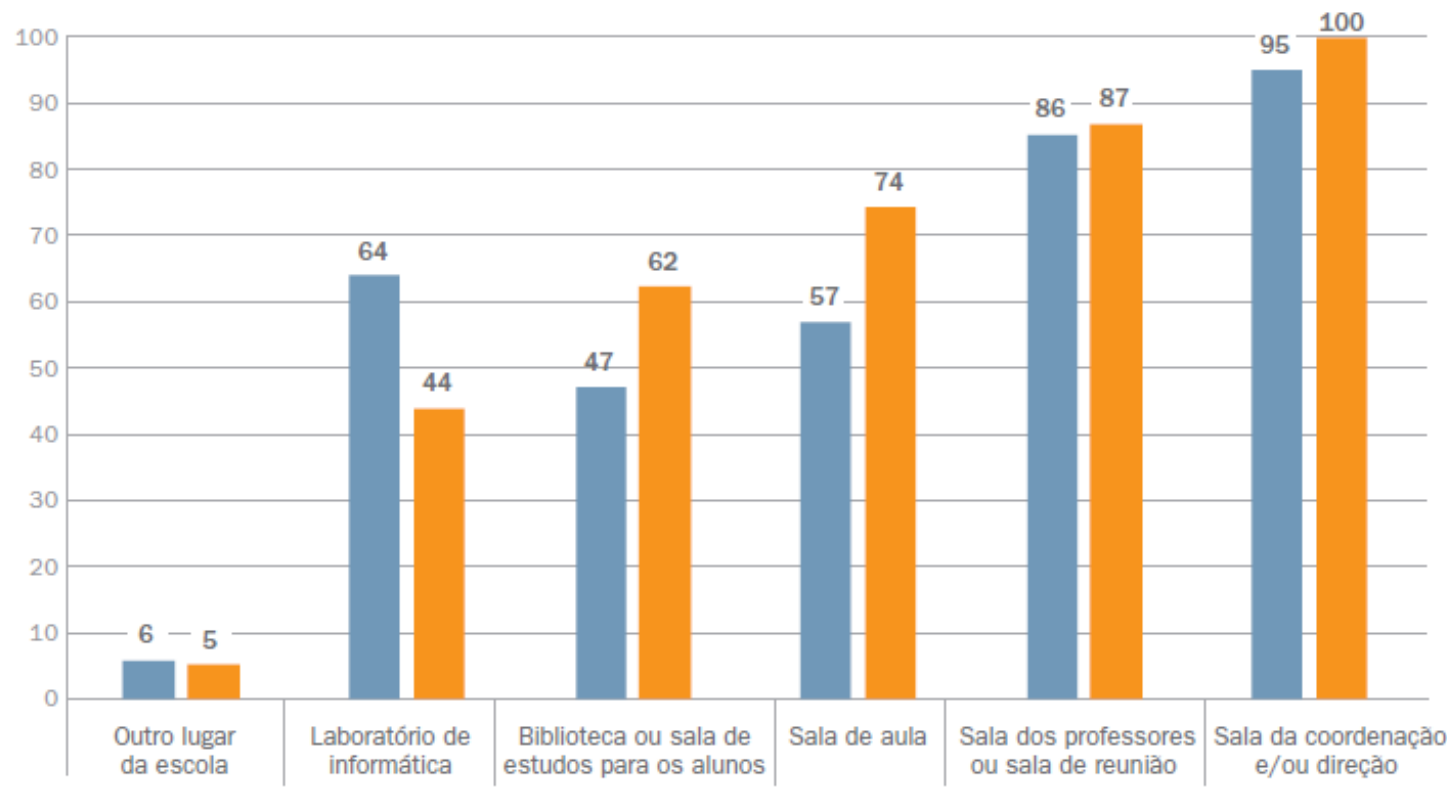

ESCOLAS PÚBLICAS

Fonte: Comitê Gestor da Internet no Brasil (2019, p. 122).

Ademais, verifica-se pontos de atenção em relação às velocidades de conexão declaradas pelas escolas. Isso se mostra relevante, já que afora a disponibilidade de equipamentos e dispositivos, a conectividade das escolas também é influenciada pela conexão à Internet, pois variações na qualidade da conexão podem impactar o uso das redes para atividades pedagógicas. De acordo com a publicação a baixa qualidade da conexão pode ser, justamente, um dos principais aspectos que limitam a disponibilidade de acesso à Internet para os alunos nos espaços da escola, principalmente entre as instituições públicas.

Os dados coletados com os gestores escolares apontaram que houve uma melhoria nas faixas de velocidade de conexão com a Internet nas escolas públicas, principalmente na faixa de $11 \mathrm{Mbps}$ ou mais, conforme demonstrado no Gráfico 3. Tal fato pode cooperar para a ampliação de atividades relacionadas ao ensino e à aprendizagem nessas instituições. 
Gráfico 3 - Escolas urbanas, por velocidade da principal conexão com a Internet (2015-2019) Total de escolas públicas e particulares localizadas em áreas urbanas com acesso à Internet(\%)
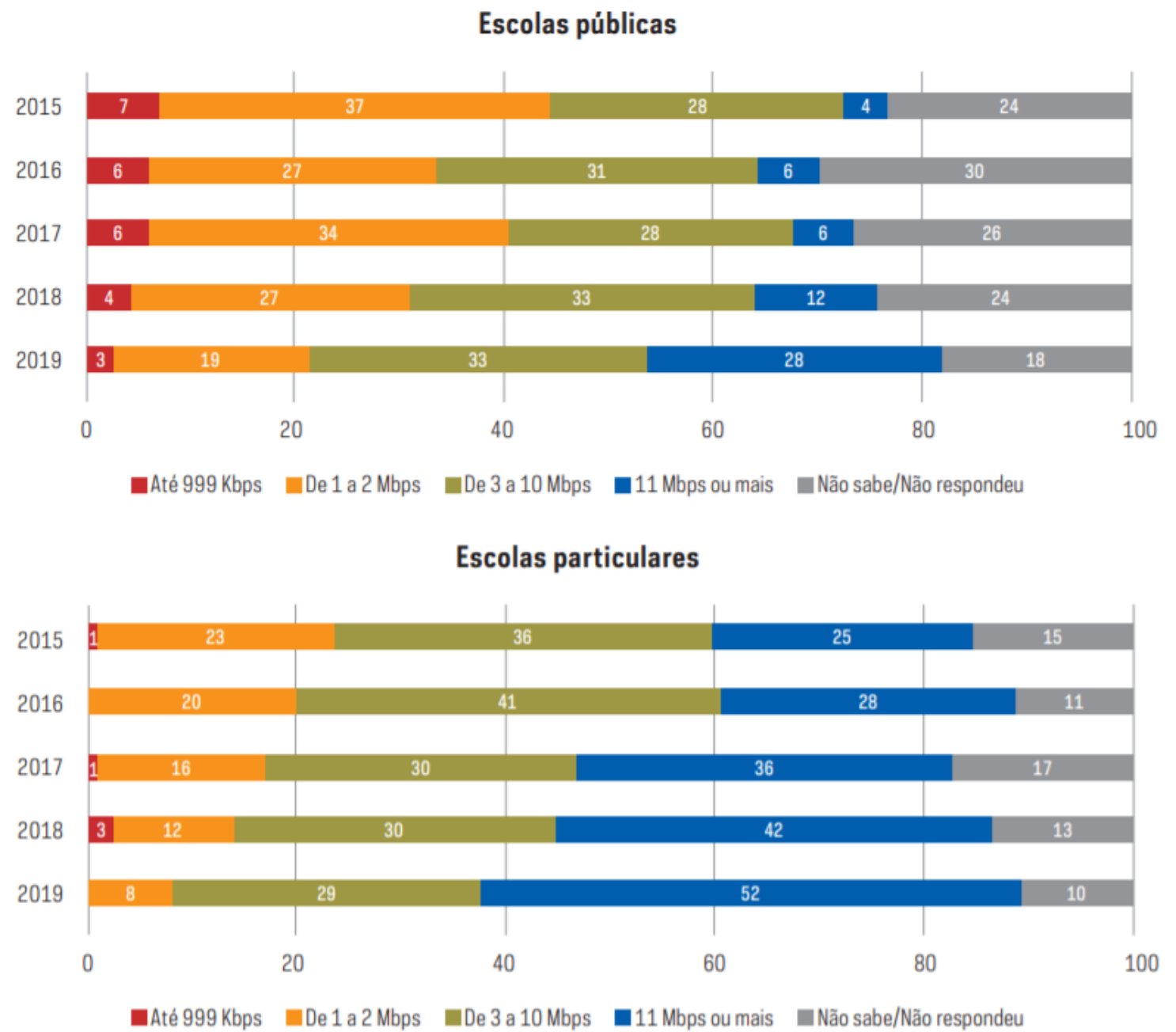

Fonte: Comitê Gestor da Internet no Brasil (2020, p. 77).

Os dados registrados no gráfico revelam uma diferença considerável na velocidade de conexão à Internet entre escolas públicas e particulares. Enquanto nestas últimas mais da metade das instituições (52\%) contam com $11 \mathrm{Mbps}$ ou mais de velocidade, nas instituições públicas mais da metade têm no máximo 10 Mbps, sendo 3\% até 999 Kbps, $19 \%$ de 1 a 2 Mbps e 33\% de 3 a 10 Mbps, somando 55\%. Segundo a publicação, a Resolução FNDE nº 9/2018 sinaliza que o ideal é que as escolas tenham conexão de, pelo menos, $100 \mathrm{Kbps}$ por aluno.

Desse modo, de acordo com a pesquisa realizada em 2018, os principais desafios para a efetivação do uso das tecnologias nas escolas, principalmente nas escolas públicas de acordo com os diretores, são o aumento de computadores por aluno (28\%) e o aumento da velocidade da internet (17\%), ou seja, aspectos relacionados à infraestrutura devem se constituir em ações primordiais para incorporar o uso das tecnologias nas práticas pedagógicas. 
Segundo publicação de 2020, antes mesmo da pandemia COVID-19, a baixa qualidade ou a ausência do acesso à internet já era cada vez mais reconhecida internacionalmente como uma das dimensões que pode impactar de maneira expressiva as oportunidades de desenvolvimento integral de crianças e adolescentes, em espacial aqueles que também estão mais suscetíveis variações socioeconômicas. Em vista disso, em julho de 2020, a Rede Nacional de Pesquisa e Ensino (RNP) divulgou uma chamada para operadoras de telefonia móvel, a fim de apoiar o Ministério da Educação, para ofertar pacotes de dados móveis para alunos de baixa renda matriculados em universidades e institutos federais. Essa ação pode ser um exemplo de uma estratégia que pode ser implementada em outros contextos, como na Educação Básica, oferecendo recursos de maneira direta aos estudantes.

Dessa forma, o ensino remoto demandou diversas adaptações das escolas que, sem dúvidas, elas não estavam preparadas. Conforme revelado na pesquisa, em 2019, somente 14\% das escolas públicas (sendo que nas escolas municipais essa proporção era de apenas 10\%) tinham uma plataforma ou ambiente virtual de aprendizagem que possibilitasse a disponibilização de atividades para alunos. Nas escolas particulares essa percentagem era de 64\%, um aumento significativo quando comparado em 2016, com 44\%.

Assim, nesse contexto pandêmico, a publicação mostra que as redes sociais passaram a ser utilizadas no compartilhamento de conteúdos para os alunos, na transmissão de aulas online, funcionando como ambientes virtuais de aprendizagem. Os dados registram que $73 \%$ das escolas públicas e $94 \%$ das escolas particulares possuíam perfil nas redes sociais.

A pandemia também escancarou as desigualdades de acesso às tecnologias digitais entre as diferentes camadas socioeconômicas. A publicação dos dados da TIC Educação, destaca dados da pesquisa TIC Domicílios de 2019 que mostra que 61\% dos lares brasileiros não contavam com computador, desses $86 \%$ pertenciam às classes DE. Mostrou também que $28 \%$ dos domicílios não possuíam nenhum tipo de acesso à Internet. A proporção entre os lares da classe DE era de $50 \%$.

Ainda de acordo com os dados da TIC Educação, no que concerne à população de alunos da Educação Básica, em 2019, a proporção de alunos usuários de Internet era de $83 \%$. Entretanto esse acesso acontece de maneira diferente nas regiões brasileiras, demonstrando novamente desigualdades de acesso entre os estudantes dependendo da região do país. Três regiões apresentaram os maiores índices de alunos usuários da Internet: 88\% no Sudeste, 87\% no Sul e $86 \%$ no Centro-Oeste. Ao passo que no Nordeste a percentagem era de $78 \%$ e no Norte, $73 \%$. 
Outro dado da pesquisa que precisa ser evidenciado é que a presença de computadores de mesa nos domicílios dos alunos vem caindo, especialmente entre os alunos de escolas particulares. Em 2019, apenas 39\% dos alunos possuíam computador de mesa, e em 2011 o percentual era de $56 \%$. Em contrapartida os computadores portáteis registraram um aumento entre 2011 (25\%) e 2015 (49\%) e desde então, permaneceu com níveis praticamente estáveis até 2018 , e uma queda maior em 2019, com 41\%. Um movimento diverso é possível observar com os tablets, visto que houve um aumento de estudantes que declararam possuir o dispositivo em casa entre 2014 e 2015, passando e 19\% para 40\%, em 2018 eram 35\% e em 2019, essa proporção caiu para $29 \%$, conforme demonstrado no Gráfico 4.

Gráfico 4 - Alunos de escolas urbanas por tipo de computador existente no domicílio (20112019)

\section{Total de alunos que estudam em escolas localizadas em áreas urbanas (\%)}

100

80

60

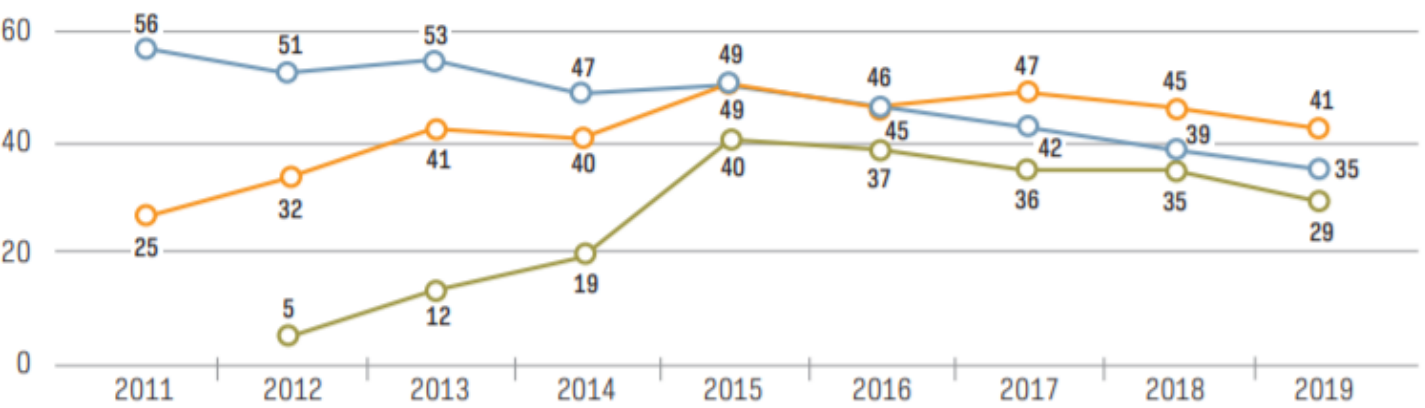

$\multimap-$ Computador de mesa $\multimap-$ Computador portátil $\multimap-$ Tablet

Fonte: Comitê Gestor da Internet no Brasil (2020, p. 25).

Outro fator que precisa ser levado em conta é o local em que esses estudantes acessam a Internet. A pesquisa realizava em 2018 mostrava que a escola não se constituía como um local prioritário de uso da Internet entre os alunos, já que um pouco mais de um terço, 37\%, deles afirmavam que utilizam a Internet nas instituições escolares, porcentagem inferior a outros locais públicos como shoppings, igrejas ou lanchonetes (57\%) e nos deslocamentos, nas ruas e em meios de transporte (52\%). Esse uso se mostrava progressivo no decorrer das faixas etárias, uma vez que segundo os dados coletados, um em cada dez alunos (12\%) do $5^{\circ}$ ano do Ensino Fundamental disse que acessava a Internet na escola, essa proporção era maior entre os alunos do $9^{\circ}$ ano do Ensino Fundamental (41\%) e subia para $62 \%$ com os alunos do $2^{\circ}$ ano do Ensino 
Médio. É preciso salientar que como a própria publicação trata, os alunos geralmente não podiam acessar a Internet pelo celular nas escolas, assim, essa talvez fosse uma das razões dos estudantes afirmarem não acessavam a rede das instituições escolares. Outra razão podia ser a falta de disponibilidade de acesso à rede, já que em 66\% das escolas urbanas a rede WiFi era bloqueada com senha e os alunos não podiam acessá-la.

Já a pesquisa de 2019, apresentou que 62\% dos alunos de escolas públicas acessavam a rede em locais onde geralmente havia acesso gratuito ou livre, como shoppings, lanchonetes e igrejas. Revelou também que 37\% dos alunos acessavam a Internet de centros públicos de acesso gratuito como entidades comunitárias e bibliotecas. A própria publicação ressalta que com o fechamento desses locais em virtude da pandemia, uma parcela considerável desses alunos pode ter ficado sem condição de acesso à rede.

\subsubsection{Dados sobre práticas docentes}

No que diz respeito à utilização das tecnologias digitais com fins nas atividades escolares, tinha-se $56 \%$ dos alunos de escolas públicas e $68 \%$ de escolas particulares utilizando os aparelhos celulares. Percebe-se um aumento expressivo no uso das redes sociais ${ }^{30}$, em especial, do WhatsApp na realização de atividades escolares, conforme mostra o gráfico 5 a seguir. De acordo com a publicação, em 2014 apenas 6\% dos alunos utilizavam essa ferramenta para realizar atividades da escola. Essa porcentagem passa para 61\% em 2019.

\footnotetext{
${ }^{30} \mathrm{O}$ fato de a pesquisa mostrar os dados de uso das redes sociais não isenta de uma reflexão adequada sobre a idade de acesso à essas ferramentas. Com a Lei Geral de Proteção de Dados (LGPD) nº 13.709/2018, que tem como principal objetivo proteger os direitos fundamentais de liberdade e de privacidade e o livre desenvolvimento da personalidade da pessoa natural, garantindo regulamentação no tratamento dos dados pessoais, os adolescentes só deveriam ter acesso às redes sociais a partir dos 13 anos. A LGPD dedicou uma seção especial para assegurar a proteção específica ao tratamento de dados pessoais de crianças e de adolescentes - Seção III da LGPD, "Do Tratamento de Dados Pessoais de Crianças e Adolescentes" - que engloba o artigo 14 e seus seis parágrafos. Essa regulação, para sua efetividade, deve dialogar com as demais normas protetivas contidas na Constituição Federal, no Estatuto da Criança e do Adolescente e na Convenção das Nações Unidas sobre os Direitos da Criança. Dessa forma, o consentimento expresso de pais ou responsáveis para acesso às redes sociais somente é exigido para tratamento de dados de crianças menores de 12 anos. No caso dos adolescentes (de 12 a 18 anos) não há uma regra específica nos termos da LGPD. No entanto, entende-se que menores de 16 anos e jovens entre 16 e 18 têm limitações de poder e capacidade de decisão em diferentes situações da vida, salvo exceções em que há autorização expressa dos pais ou responsáveis.
} 
Gráfico 5 - Alunos de escolas urbanas, por redes sociais nas quais possuem perfil e utilizadas para trabalhos escolares (2015-2019)

Total de alunos que estudam em escolas localizadas em áreas urbanas e usuários de Internet(\%)

\section{Redes sociais nas quais os alunos possuem perfil}

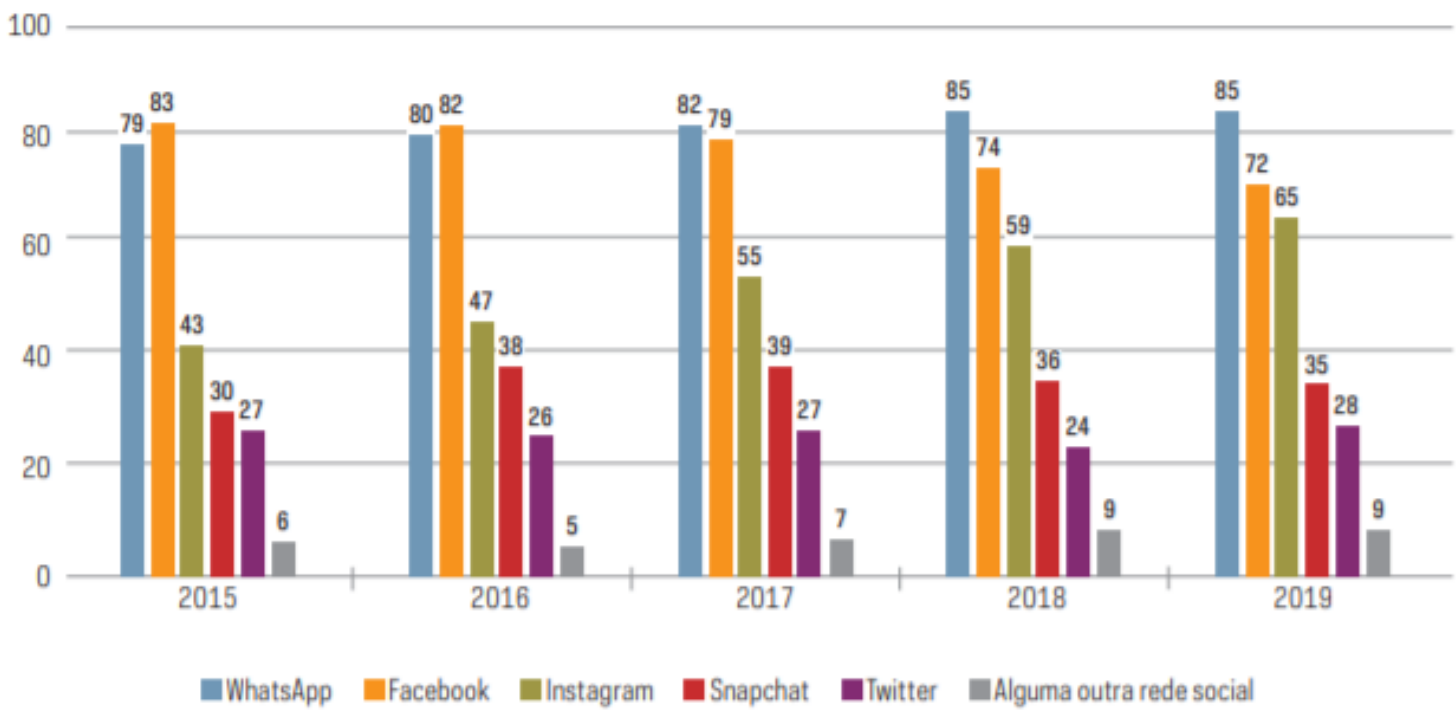

Redes sociais utilizadas pelos alunos em trabalhos escolares

100

80

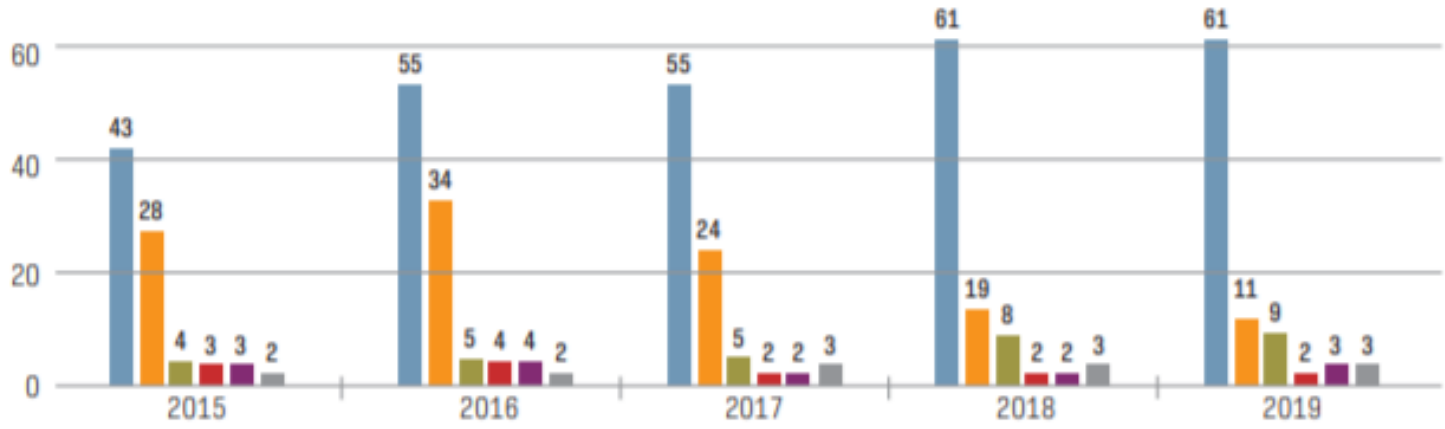

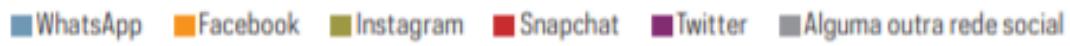

Fonte: Comitê Gestor da Internet no Brasil (2020, p. 84).

Nos dados da pesquisa de 2018, já destacavam as atividades realizadas pelos alunos na Internet: 93\% assistiam vídeos, programas, filmes e séries online, $88 \%$ enviavam mensagens por aplicativos, $87 \%$ faziam pesquisas na Internet, seja por curiosidade ou vontade própria e 80\% usavam das redes sociais. Mas, a utilização da Internet para produzir conteúdos havia proporção menor, $44 \%$ para postagens de texto, imagens ou vídeos pelos próprios estudantes. É possível constatar também diante dos dados que, de fato conforme as habilidades e a maior 
autonomia para uso dos recursos, maior uso se faz, visto que menos da metade (44\%) dos alunos do $5^{\circ}$ ano do Ensino Fundamental compartilhavam de maneira online, textos, imagens e vídeos, essa proporção crescia para $70 \%$ com alunos do $9^{\circ}$ ano do Ensino Fundamental e ia para $80 \%$ dos alunos do $2^{\circ}$ do Ensino Médio.

A pesquisa de 2019 , por sua vez, demonstra que somente $28 \%$ dos estudantes haviam utilizado a rede para se comunicar com seus professores e $16 \%$ para participarem de cursos online. Isso corrobora para a ideia de que no contexto do ensino remoto imposto pela pandemia, a maioria dos alunos precisou desenvolver novas habilidades para acessar conteúdos escolares, quando havia essa possibilidade.

No que se refere ao acesso à Internet pelos professores, a pesquisa mostra que $99 \%$ dos docentes de instituições públicas e $100 \%$ dos de escolas particulares se conectam por meio do telefone celular. Nesse sentido, os dados revelam que possivelmente é graças a esses aparelhos que o acesso está praticamente universalizado entre os docentes. Além disso, a maioria deles que lecionam em áreas urbanas (92\%) possuía computadores em domicílio, principalmente dispositivos portáteis.

Ao contrário do que acontece com os estudantes, a escola sempre foi um dos principais espaços de acesso à Internet por parte dos docentes. Segundo os dados da pesquisa, em 2011, $75 \%$ dos professores de escolas urbanas afirmavam usar a rede dentro da escola. Esse percentual chegou a 93\% em 2019, de modo que a escola, depois dos lares, é o local de acesso mais mencionado por esse grupo.

Também é possível verificar o uso mais intenso das tecnologias quando se analisa os dados referentes às atividades realizadas pelos docentes: quase que a totalidade deles se comunicou por meio de mídias digitais, tais como mandar mensagens por meio de aplicativos (99\%), ler jornais, revistas ou notícias na Internet (97\%), assistir a programas, vídeos, séries ou filmes na Internet (95\%), compartilhar conteúdos, como imagens, vídeos ou textos (91\%) e acessar redes sociais (88\%). Esses dados têm proporções muito similares entre docentes de instituições públicas e privadas, com exceção da busca por cursos de graduação, pós-graduação e extensão, visto que conta com $69 \%$ dos que dão aulas em escolas públicas e $86 \%$ dos que lecionam nas instituições privadas.

Desse modo, ainda que os professores demonstrem pertencer a um grupo com hábito de uso intensivo de tecnologias digitais, os dados apontam que esse aspecto não reflete, muitas vezes, em sua prática profissional. Isso porque na pesquisa verificou-se que $15 \%$ dos docentes das escolas públicas urbanas declararam que nunca utilizam a Internet em atividades com os 
alunos, $28 \%$ deles utiliza pelo menos uma vez na semana, outros 9\% usam a Internet ao menos uma vez por dia e, $8 \%$ mais de uma vez por dia.

Esses dados se mostram ainda mais relevantes quando se considera as atividades pedagógicas propostas pelos professores. O Gráfico 6 a seguir é referente a pesquisa de 2018 e aponta para a variação entre as atividades realizadas com os alunos e estas mesmas atividades com o uso de tecnologias. Essa diferença se mostra relevante desde atividades não tão intuitivas para utilizar tecnologias digitais, como interpretação de textos, até na elaboração de gráficos e planilhas em que há recursos tecnológicos simples e básicos para fazê-lo. Chama atenção que mesmo a atividade com jogos educativos e aplicativos proposta por $45 \%$ dos docentes, apenas $20 \%$ a utiliza com o uso de tecnologias. O uso mais expressivo das tecnologias em atividades é em aulas expositivas (39\%), o que indica que provavelmente, o uso da tecnologia está como apoio de materiais, como uma apresentação, por exemplo. O segundo uso das tecnologias em atividades mais mencionado é a solicitação de realização trabalhos sobre temas específicos (38\%) dos $87 \%$ totais, em que provavelmente se recorre a pesquisa de textos, vídeos e imagens sobre o tema.

Gráfico 6 - Professores de escolas públicas urbanas, por atividades pedagógicas realizadas com alunos e atividades realizadas com alunos a partir do uso de tecnologias (2018) Total de professores que lecionam em escolas públicas localizadas em áreas urbanas (\%)

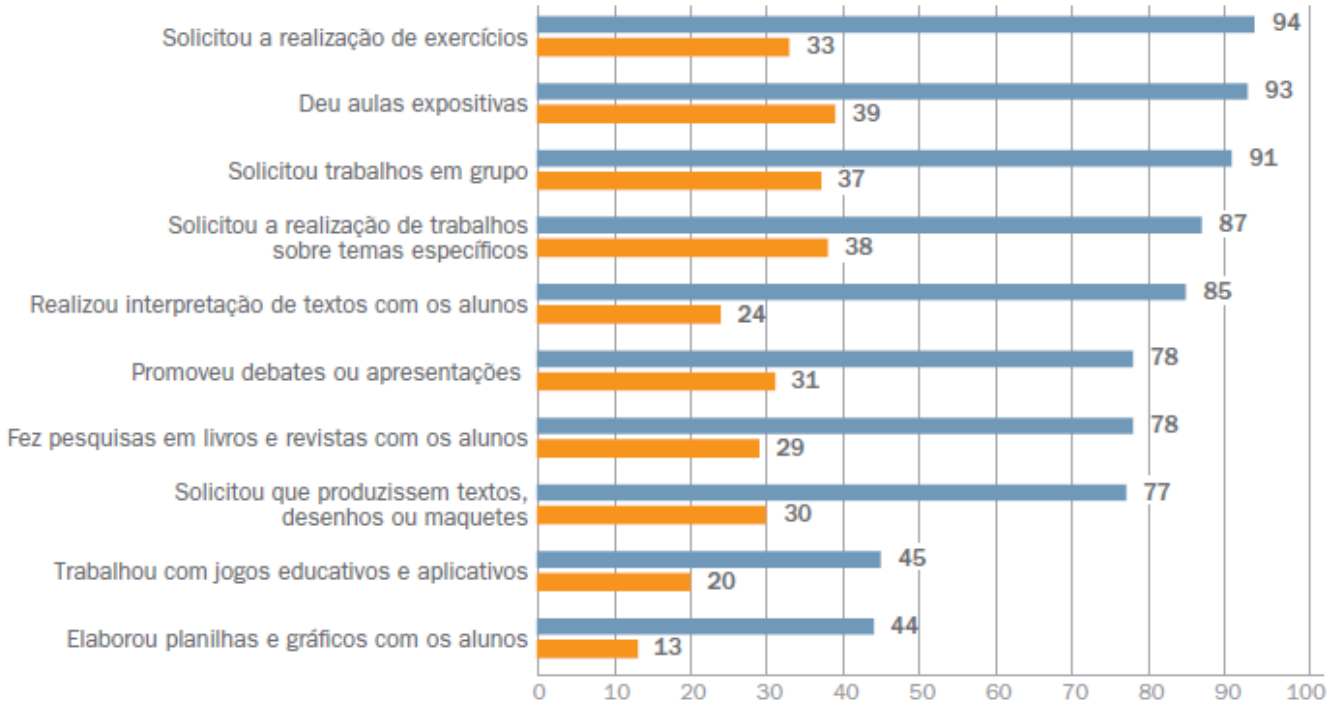

atividades realizadas com os alunos atividades realizadas com o uso de teCNOLOGias

Fonte: Comitê Gestor da Internet no Brasil (2019, p. 124).

Assim sendo, entende-se que os docentes utilizam as tecnologias digitais para expor conteúdos, solicitar ou fazer pesquisas com os estudantes acerca de temas trabalhados em suas 
aulas, planejar suas propostas. No entanto, nem sempre as atividades que envolvem o uso das tecnologias digitais contam com a participação direta dos alunos, principalmente quando acontecem na sala de aula. Uma das justificativas possíveis se deve ao fato das dificuldades no compartilhamento de rede como já foi mencionado com os dados anteriores.

De maneira semelhante, os dados coletados em 2019, demonstram que o uso das tecnologias é bastante frequente na preparação das aulas e atividades, mas por vezes não pressupõem o uso pelos alunos, conforme se verifica no Gráfico 7. Em 2019, 85\% dos docentes usuários de Internet de escolas urbanas, utilizaram a rede para buscar planos de aula e 79\% para acessar portais de professores. Contata-se que o uso mais expressivo de professores de escolas públicas está na elaboração de questões de prova e avaliações (86\%). Uma diferença marcante entre docentes de instituições públicas e privadas está nos planos de aula, contando com 64\% do primeiro grupo e $42 \%$ do segundo. Segundo a publicação, essa diferença pode se dar pelo fato de que em muitas escolas privadas há com planos de aula produzidos por sistemas de ensino

Gráfico 7 - Professores de escolas urbanas, por tipo de recurso obtidos na internet para a preparação de aulas ou atividades com alunos (2019)

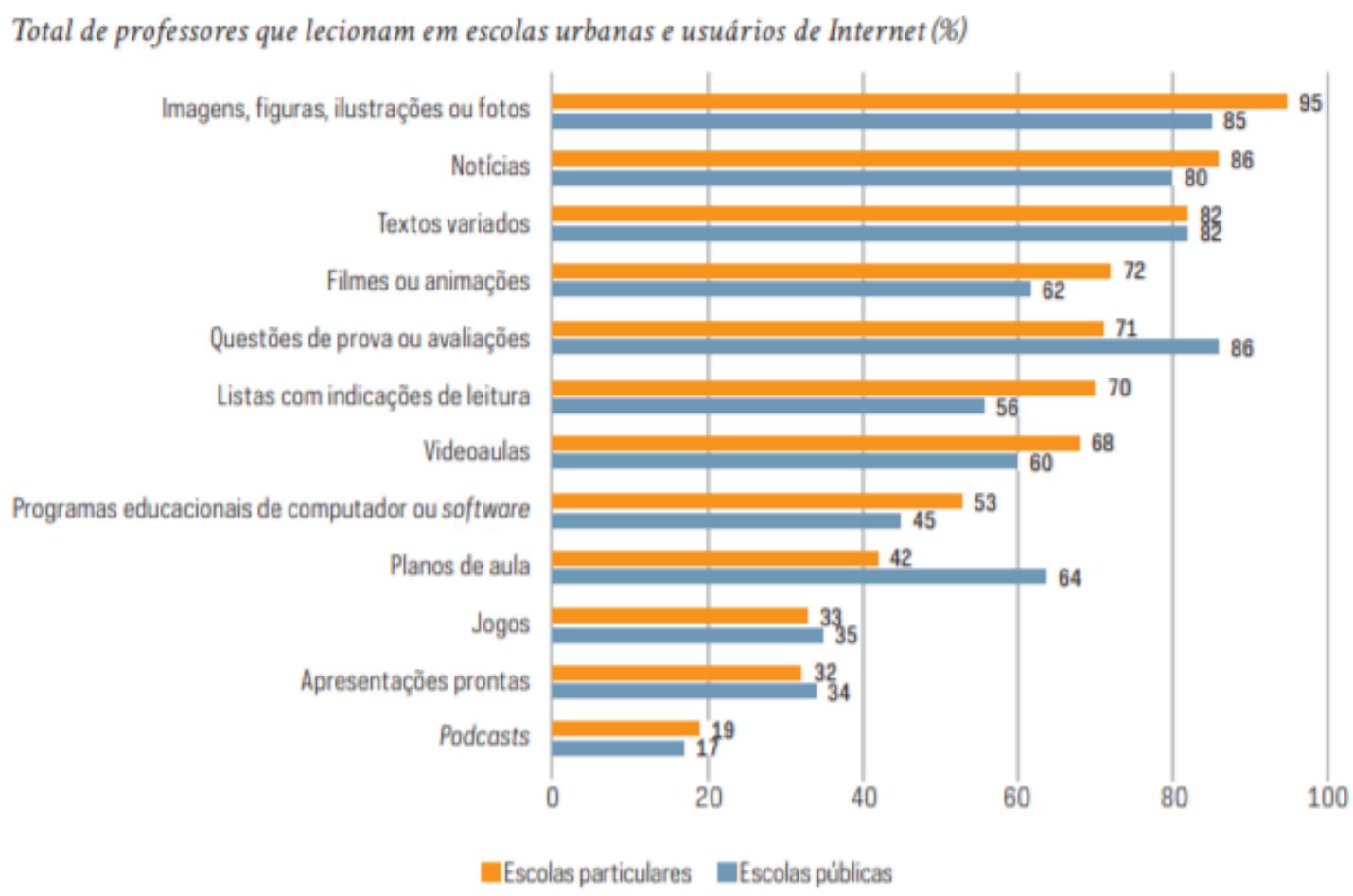

Fonte: Comitê Gestor da Internet no Brasil (2020, p. 94).

Outros dados do gráfico também chamam a atenção, entre eles, o aumento da percentagem de utilização de podcasts, $19 \%$ nas escolas privadas e $17 \%$ nas públicas. Por outro lado, observa-se também que filmes, animações e videoaulas foram mais citados pelos 
professores de escolas particulares (72\%), do que pelas públicas (62\%) provavelmente, porque requerem maior capacidade de velocidade de conexão à rede.

Além disso, de acordo com os dados da pesquisa de 2019, dos 94\% dos professores que afirmavam ter dado aulas expositivas, apenas $55 \%$ declararam ter usado computador ou a Internet durante essa proposta. $\mathrm{O}$ mesmo pode ser observado em outras atividades, como $75 \%$ dos docentes solicitaram pesquisas em livros e revistas, mas somente $36 \%$ utilizaram recursos digitais. Com a mesma tendência, dos $44 \%$ dos professores que construíram planilhas e gráficos com seus alunos, apenas $18 \%$ utilizaram as tecnologias, conforme se verifica na Tabela 1.

Tabela 1 - Professores de escolas urbanas, por uso do computador e da Internet para realizar atividades com os alunos (2016-2019)

Total de professores que lecionam em escolas urbanas e usuários de Internet (\%)

\begin{tabular}{|c|c|c|c|c|c|c|c|c|}
\hline & \multicolumn{4}{|c|}{ Escolas públicas } & \multicolumn{4}{|c|}{ Escolas particulares } \\
\hline & 2016 & 2017 & 2018 & 2019 & 2016 & 2017 & 2018 & 2019 \\
\hline Deu aulas expositivas & 48 & 43 & 39 & 49 & 69 & 65 & 74 & 82 \\
\hline $\begin{array}{l}\text { Solicitou a realização de } \\
\text { trabalhos sobre temas } \\
\text { especificos }\end{array}$ & 38 & 43 & 38 & 44 & 53 & 66 & 57 & 58 \\
\hline Solicitou trabalhos em grupo & 39 & 37 & 37 & 40 & 55 & 53 & 58 & 54 \\
\hline $\begin{array}{l}\text { Solicitou a realização de } \\
\text { exercicios }\end{array}$ & 37 & 34 & 33 & 39 & 53 & 65 & 48 & 62 \\
\hline $\begin{array}{l}\text { Promoveu debates ou } \\
\text { apresentações com os alunos }\end{array}$ & 32 & 30 & 31 & 33 & 37 & 43 & 54 & 53 \\
\hline $\begin{array}{l}\text { Realizou interpretação de textos } \\
\text { com os alunos }\end{array}$ & 24 & 27 & 24 & 31 & 38 & 43 & 51 & 57 \\
\hline $\begin{array}{l}\text { Fez pesquisa em livros e revistas } \\
\text { com os alunos }\end{array}$ & 29 & 30 & 29 & 31 & 43 & 41 & 48 & 56 \\
\hline $\begin{array}{l}\text { Solicitou que os alunos } \\
\text { produzissem textos, desenhos ou } \\
\text { maquetes }\end{array}$ & 33 & 28 & 30 & 29 & 40 & 56 & 44 & 56 \\
\hline $\begin{array}{l}\text { Trabalhou com jogos educativos } \\
\text { com os alunos }\end{array}$ & 21 & 20 & 20 & 24 & 24 & 49 & 41 & 45 \\
\hline $\begin{array}{l}\text { Elaborou planilhas e gráficos com } \\
\text { os alunos }\end{array}$ & 17 & 13 & 13 & 15 & 20 & 40 & 26 & 32 \\
\hline
\end{tabular}

Fonte: Comitê Gestor da Internet no Brasil (2020, p. 88).

Outro aspecto importante trazido pela publicação é que em 2019, 51\% dos professores das escolas urbanas declararam ter disponibilizado conteúdos na Internet, $48 \%$ afirmaram ter tirado dúvidas dos alunos pela rede e $35 \%$ haviam utilizado recursos e ferramentas da rede para 
receber trabalhos e atividades dos alunos. Isso demonstra, mais uma vez, que o contexto da pandemia exigiu uma grande reconfiguração da relação de alunos e professores via rede.

A pesquisa revela ainda que em 2019, 98\% dos professores de escolas particulares usuários da Internet e 95\% das escolas públicas, asseguravam que já tinham usado algum tipo de conteúdo digital na preparação de aula ou em atividades com seus alunos. Sendo que, desses, 89\% fizeram algum tipo de edição do material da rede, e $81 \%$ criaram algum material a partir da combinação de vários outros materiais. Destaca-se ainda que, nesse mesmo ano, apenas 32\% publicaram ou postaram na Internet algum conteúdo produzido para utilizar nas atividades com os alunos ou nas aulas. Certamente isso mudou expressivamente meses depois, com a pandemia e o ensino remoto. Dentre as justificativas mencionadas pelos professores para esse percentual baixo estava a falta de tempo (52\%), equipamentos ultrapassados (49\%), baixa conexão com a Internet (40\%), falta de conhecimento de como criar e produzir conteúdo (33\%) e desconhecimento acerca de como publicar (24\%). Esses índices mostram que a formação e a preparação dos docentes poderiam ter amenizado, em certa medida, as dificuldades enfrentadas durante o ensino remoto.

No entanto, percebe-se um movimento dos professores na busca por informações sobre o uso das tecnologias digitais e por formação, visto que $82 \%$ dos docentes das instituições públicas e privadas dos locais urbanos declararam ter desenvolvido ou aprimorado seus conhecimentos sobre o uso de tecnologias para os processos de ensino e aprendizagem. Essa busca por informações e formações têm ocorrido de maneira mais frequente por meio de iniciativas próprias dos professores, não institucionalizadas e apoiadas pelas escolas ou secretarias de Educação, citada por 93\% dos docentes de escolas públicas e 94\% de particulares.

Tendo em vista, os dados apresentados pelo Cetic.br e as diretrizes expressas na BNCC, compreende-se que as possibilidades de acesso as tecnologias digitais ainda estão longe do que se prevê e espera. Como já apontava Coll, Mauri e Onrubia (2010, p. 71),

a incorporação das TIC na educação está, portanto, longe de apresentar um panorama tão homogêneo quanto às vezes se supõe, e seus efeitos benéficos sobre a educação e ensino distam muito de ser tão generalizados quanto às vezes se insinua, entre outras razões porque na maioria dos cenários de educação formal e escolar as possibilidades de acesso e uso dessas tecnologias ainda são limitadas ou mesmo inexistentes.

Somado ao desafio do acesso, estudos realizados até agora (COLL; MONEREO, 2010, por exemplo), mostram que, em geral, tem-se a dificuldade de implementar usos educacionais das tecnologias digitais em propostas de uso pedagógico e didático que de fato potencializem e considerem o ensino e aprendizagem com uma lógica diversa, representando melhorias nesse processo, uma vez que essas inserções são limitadas 
Apesar disso, acredita-se que o caminho não seja rebaixar as expectativas em relação às tecnologias digitais nas salas de aula para promover e melhorar a aprendizagem, mas tratá-las como potencial, que como afirmam Coll, Mauri e Onrubia (2010, p. 66, grifo do autor), "O que ocorre é que se trata de um potencial que pode ou não vir a ser uma realidade, e pode tornar-se realidade em maior ou menor medida, em função do contexto no qual as TIC, serão, de fato utilizadas". Por conseguinte, são os contextos de uso dessas tecnologias que determinam o impacto nas práticas pedagógicas e na mudança do processo de ensino-aprendizagem. No entanto, outros estudos apontam para a dificuldade em estabelecer relações causais entre a utilização das tecnologias digitais e a melhoria da aprendizagem. Desse modo, o interesse desloca-se das potencialidades volta-se para os usos efetivos de professores e alunos, tendo sempre em vista quais são as mudanças nas práticas pedagógicas relacionadas a esses usos.

Desse modo, esses dados são importantes porque, além de mostrarem o cenário das TIC na atualidade, ajudam a situar a escola em que a pesquisa foi realizada, evidenciando o lugar que as tecnologias digitais ocupam nessa instituição. Conforme se discutiu no Capítulo 1 , Cadernos analógicos e digitais: inovação e mudança na cultura escolar, ao considerar a instituição de ensino em que a pesquisa foi realizada, assume-se que as tecnologias digitais se constituem como uma inovação, já que a instituição é reconhecida por seus estudantes fazerem um amplo uso desses recursos, diferentemente do que ocorre em grande parte das escolas da cidade de São Paulo e do país. De acordo com o que se verificou na discussão teórica apresentada, a inovação associa-se a práticas caracterizadas pelo isolamento, a fragmentação, a descontinuidade no tempo, a baixa visibilidade e o forte voluntarismo das pessoas que são suas agentes; o que se observou foi justamente que essas práticas não se constituem como uma mudança sistêmica na cidade, tampouco como uma reforma educacional implementada (GHANEM JUNIOR, 2013).

Contudo, dentro da própria instituição, o uso dos tablets pode ser considerado como uma mudança, pois toda a escola utiliza esse aparelho como um material obrigatório para os alunos desde 2014, não dependendo da escolha do professor, nem da série na qual o aluno está inserido. Ou seja, houve alteração sistêmica dentro dessa escola, caracterizando assim, segundo o autor, uma mudança. Apesar de a instituição ter os tablets entre os materiais obrigatórios dos alunos, sendo considerada uma inovação quando comparada a outras escolas, ainda é preciso cautela para não confundir inovações pedagógicas com tecnológicas. Isso porque a inserção da tecnologia nas escolas não representa, por si só, alteração de práticas pedagógicas. E esta é a característica fundamental tanto da inovação, quanto da mudança e das reformas educacionais, conforme assinalado por Ghanem Junior e Fullan. 
Tendo em vista os documentos do plano normativo, os dados do cenário real do acesso e dos usos das tecnologias na educação e a localização da escola pesquisada nesse contexto, os próximos capítulos destinam-se a analisar os cadernos escolares e as entrevistas dos estudantes. 


\section{MODOS DE REGISTRO EM DOIS CENÁRIOS: ENTRE OS CONDICIONAMENTOS DOCENTES E A EXPRESSÃO DE IDENTIDADES}

Neste capítulo, pretende-se analisar os modos de registro dos alunos, atentando-se não só para a escolha do suporte de escrita, mas como estes são efetivamente utilizados pelos alunos, porquanto pode haver uma divergência entre o que os professores pensam, a instituição projeta e o modo como os alunos realmente utilizam o referido suporte. Intenciona-se investigar se, quando há a opção pelos cadernos digitais, há inovações e potencialidades consideradas pelos alunos e professores ou se o uso é muito próximo ao que se faz do caderno analógico a ponto de substitui-lo, ou ainda se as utilizações de ambos são concomitantes.

Durante o período de observação das aulas de Língua Portuguesa, foi possível verificar que alguns alunos faziam suas anotações de aula em seus IPads, embora a maior parte deles utilizasse seus cadernos de papel. Outra prática bastante comum entre os estudantes era tirar foto da lousa para completarem seus registros em um momento posterior ao da aula e/ou para guardarem-nas, a fim de estudarem para as avaliações. Tal prática funcionava, por parte dos alunos, como um jeito de garantir que os cadernos, analógicos ou digitais, estivessem sempre completos.

Também se presenciou momentos em que as três docentes regulavam as anotações dos alunos, com maior ou menor intensidade. A professora Isabela, em algumas situações, orientava-os a copiarem nos cadernos a sistematização que ela fizera na lousa, alegando que só as fotos que eles tiravam poderiam ser insuficientes, pois acabavam perdendo. Ela afirmava, por exemplo: "Pode tirar foto da lousa, mas a cópia é imprescindível.". De maneira parecida, a professora Laura, por vezes, recomendava que os alunos copiassem em seus cadernos as sínteses de conteúdos que ela escrevera na lousa, pedindo ainda que fosse feita com capricho e que utilizassem duas cores de caneta, assim como ela tivera feito. Nas falas dessas duas professoras, não havia distinção entre o uso do caderno ou do tablet. Já a professora Marina expressava que os alunos podiam escolher onde iriam fazer suas anotações, e as recomendações de cópia eram bem menos frequentes. Contudo, havia a solicitação de que eles tomassem nota de alguns apontamentos que ela fazia, especialmente nos momentos de correção das produções textuais.

Diante disso, cabe evocar o octógono dos suportes de escrita e refletir sobre a dimensão do professor, uma vez que se trata da mesma instituição de ensino, do mesmo projeto político pedagógico, do mesmo contexto, do mesmo componente curricular, do mesmo espaço e do mesmo tempo de aula, levando em consideração o planejamento das aulas e o momento do ano. 
Verifica-se, porém, uma variedade significativa no modo de lidar com os materiais, pois, enquanto alguns professores nem mencionam a possibilidade de variedade de suportes de escrita, há outros que regulam esses usos, deixando orientações claras da maneira como estes deveriam ser usados. Desse modo, reitera-se a relevância de se considerar a dimensão dos professores no uso desses instrumentos. Como afirma Coll e Monereo (2010, p. 33),

[...] uma equipe docente ou um professor com muitos anos de experiência, com sólidas concepções objetivistas e com práticas eminentemente transmissivas, provavelmente acabarão utilizando as TIC para complementar as aulas expositivas com leituras e exercícios autoadministráveis na rede, mas dificilmente farão uso destas para que estudantes participem em fóruns de discussão, trabalhem de maneira colaborativa ou procurem e contrastem informações sobre um determinado tema.

As entrevistas com os estudantes, as conversas informais com a professora e a análise dos cadernos aconteceram durante o ensino remoto, onde o digital é o meio de acessar a escola, os professores e o conhecimento. Além disso, nessa configuração, devido à distância, os suportes de escrita deixam de ser inspecionados. Vê-se, então, uma mudança em relação a escolha do material, visto que, dos seis alunos entrevistados, todos usavam cadernos analógicos antes da pandemia, e, com o ensino remoto, uma das alunas disse ter passado a usar exclusivamente cadernos digitais, como se vê neste excerto: "Faço tudo [no] IPad. Eu não uso mais caderno. [...] Foi na quarentena que eu comecei a usar o IPad.” (Julia). Nas figuras abaixo, é possível ver as fotografias do caderno de papel da Julia, com uma atividade datada de cinco de maio de 2020 (Figura 2), no segundo mês de pandemia, e a imagem do caderno digital com um registro feito no segundo semestre do ano (Figura 3). 
Figura 2 - Caderno analógico da Julia (no início do ensino remoto)

Fonte: Dados desta pesquisa (2021)

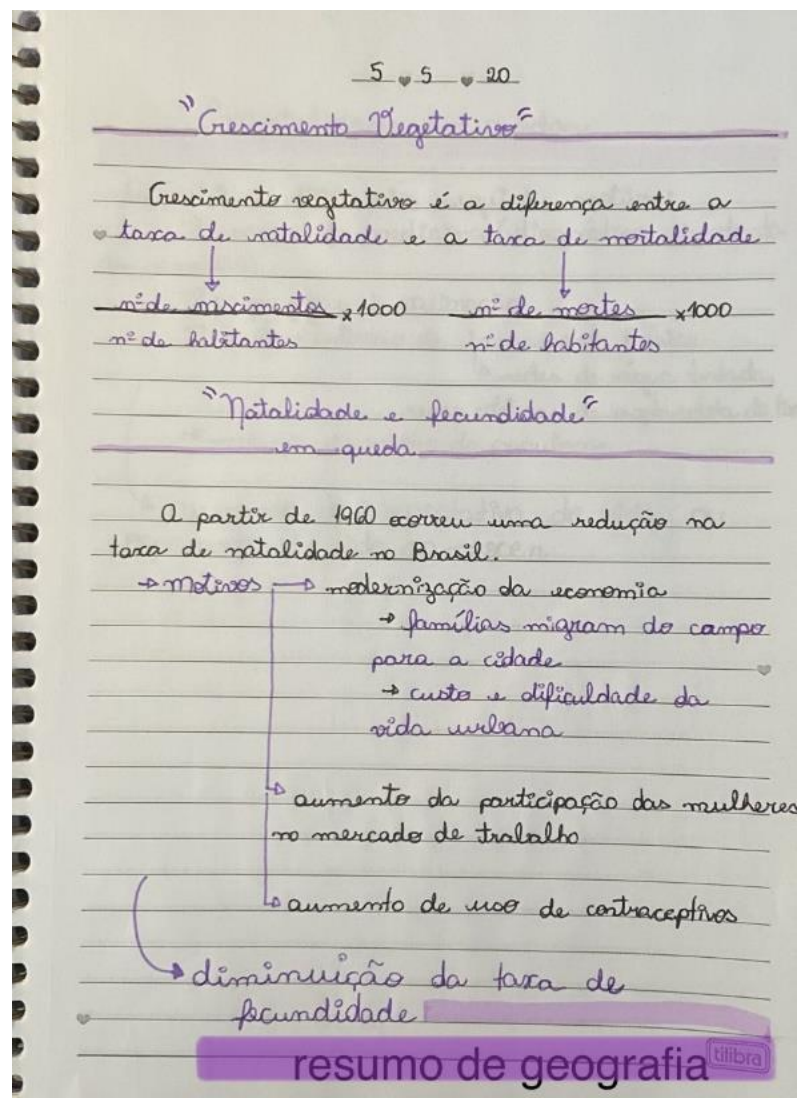

Figura 3 - Caderno digital da Julia (no fim do ano, meses depois do início da pandemia)

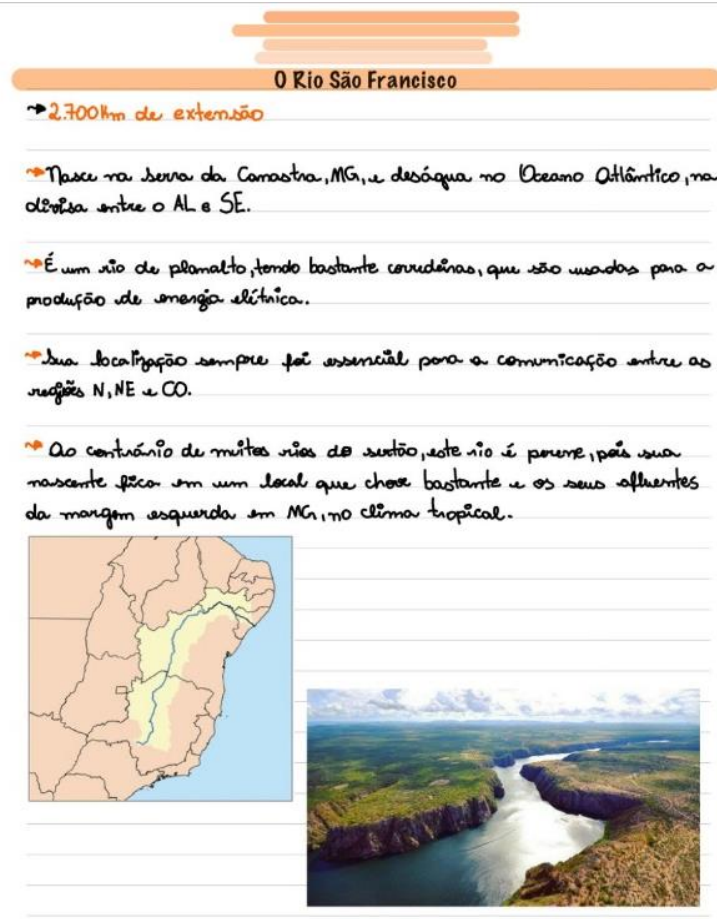

Fonte: Dados desta pesquisa (2021). 
Em ambas as figuras se têm folhas brancas pautadas, presença de setas, registros escritos em letra cursiva, com o tema de estudo centralizado no topo da página, anotações escritas em tópicos com informações destacadas e cores diferentes. A diferença mais expressiva é a presença de duas imagens no registro do caderno digital - um mapa com destaque da localização do Rio São Francisco e uma fotografia do rio.

Outros dois alunos mencionaram que fazem registros das videoaulas em seus cadernos analógicos e, quando estão estudando, usam os tablets como suporte de escrita, ambos declarando que preferem fazer seus registros de maneira digital, conforme se verifica nos trechos destacados:

[...] eu faço os registros no caderno para deixar tudo completo no caderno, mas se, por exemplo, tem um caderno digital, vamos dizer assim... eu também faço. Agora eu prefiro usar o digital, né? [...] eu faço o físico primeiro, né? Porque eu comecei o físico e aí eu vou preenchendo e aí eu passo o conteúdo do caderno físico para o digital de uma forma mais resumida. (Tomás, grifos nossos).

Para fazer os registros da escola em si eu uso mais caderno físico mesmo, mas quando eu estou estudando, que são os estudos pessoais, esse ano eu comecei a usar muito o IPad. [...] Primeiro faço os registros da aula que o professor mandou no caderno físico e aí eu pego o IPad e eu anoto as coisas que são relacionadas à aula para eu entender melhor a matéria e, aí, depois, quando eu estou próxima à avaliação ou se eu estou fazendo alguma atividade e eu não entendi, eu volto para esses resumos que eu fiz para mim mesma no IPad, e eu consulto para entender melhor. [...] No IPad é mais fácil. (Gabriela, grifo nosso).

Ao analisar fotos dos cadernos de Gabriela, é possível verificar esse percurso de estudo. Na imagem do caderno de papel (Figura 4), vê-se um texto corrido, fruto de anotações durante a aula, com partes grifadas que provavelmente foram destacadas num momento posterior enquanto estudava ou durante a própria aula, ao identificar a centralidade das informações. Já na imagem do caderno digital (Figura 5), encontra-se também um texto com partes destacadas e um desenho com esquema, mostrando uma elaboração dos estudos. 
Figura 4 - Caderno físico com anotações de aula da Gabriela

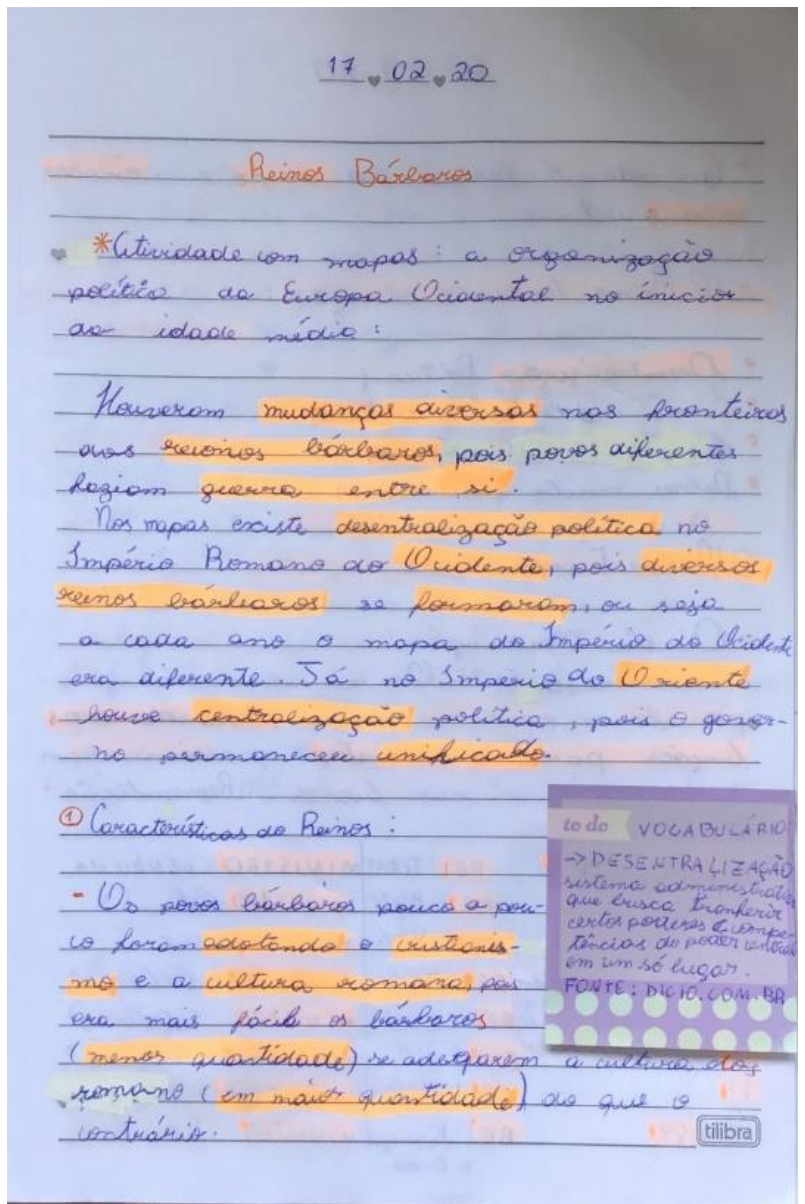

Fonte: Dados desta pesquisa (2021).

Figura 5 - Caderno digital com anotações de estudos da Gabriela

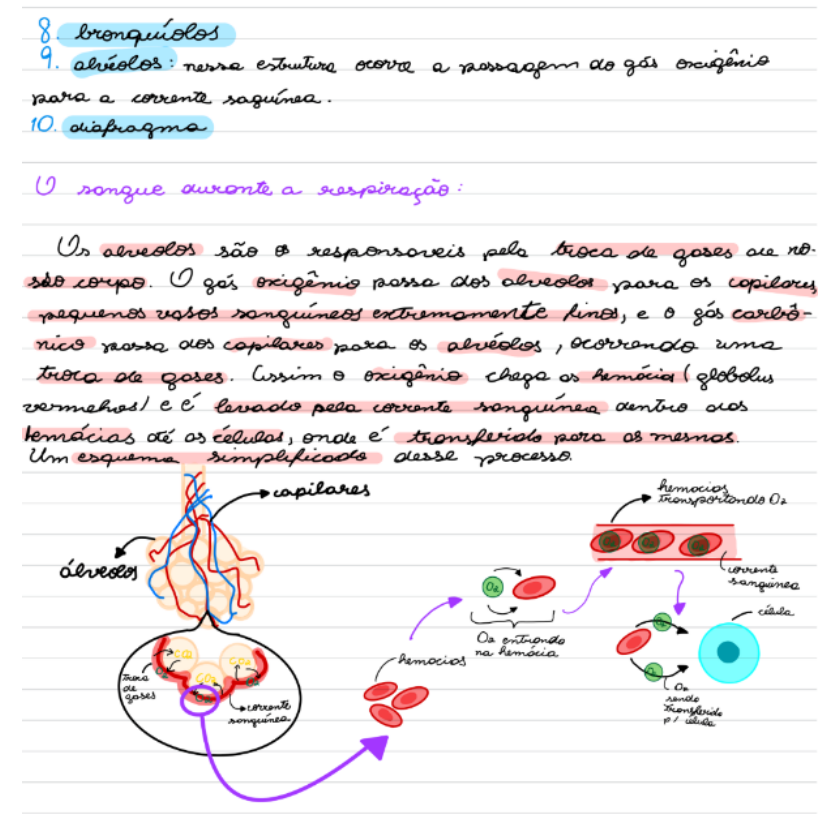

Fonte: Dados desta pesquisa (2021). 
A preferência pelo suporte digital advém de diversas motivações. Dentre as citadas pelos alunos, destaca-se: o menor peso das mochilas, uma vez que se poupam de carregar cadernos diversos e grandes estojos com diferentes canetas, levando menos materiais; a possibilidade de acessar os conteúdos de qualquer lugar, sem se restringir às anotações de um determinado caderno; a praticidade e a organização possibilitada pela criação de diferentes pastas de armazenamento e pela facilidade para resolver erros e mexer na estrutura das anotações. De acordo com a própria voz dos estudantes:

Quadro 8 - Excertos das falas dos alunos com os motivos pelos quais preferem os suportes digitais

\begin{tabular}{|c|}
\hline $\begin{array}{l}\text { "Quando eu escrevo no IPad fica tudo guardado e fica mais fácil do que fazer no físico, só que } \\
\text { no físico nem sempre eu tenho acesso das coisas que eu faço. [...] Fica mais organizado, essas } \\
\text { coisas, tem mais controle, gasta menos papel. [...] tem essa coisa de gastar papel, porque, às } \\
\text { vezes, eu imprimo errado e aí fica ruim. Quando eu erro no IPad é muito mais fácil de } \\
\text { consertar, porque você consegue mudar de lugar, apagar uma palavra, deixar tudo } \\
\text { junto." } \\
\text { (Tomás, grifos nossos) }\end{array}$ \\
\hline $\begin{array}{l}\text { "Também eu tenho todas as minhas canetas, todas as minhas cores em um lugar só, então eu } \\
\text { não preciso levar mil materiais. É muito mais prático pra mim." } \\
\text { (Gabriela, grifo nosso) }\end{array}$ \\
\hline $\begin{array}{l}\text { "Porque eu acho que é mais rápido e mais prático. [...] O caderno físico ocupa peso na mala. } \\
\text { Ele não é mais necessário, porque tem que carregar o estojo, o caderno, os livros, as folhas, a } \\
\text { pasta. No IPad é tudo um só." }\end{array}$ \\
\hline
\end{tabular}

Fonte: Elaborado pela Autora (2021).

As outras três alunas, apesar de afirmarem que mudaram o jeito de fazer seus registros com as aulas online, permanecem utilizando seus cadernos analógicos e mencionam que até fizeram tentativas de uso do suporte digital, mas preferem o papel, porque consideram que é mais prático e conseguem se organizar melhor, como se vê neste quadro:

Quadro 9 - Excertos das falas dos alunos com os motivos pelos quais preferem os suportes de papel

(continua)

"Eu prefiro fazer no papel escrito mesmo, porque eu não sou uma pessoa muito de tablet assim... Na pandemia eu tive que me adaptar, mas eu acabei fazendo alguns resumos no Word e em outras plataformas, mas eu continuo fazendo mais no papel mesmo."

(Roberta - grifo nosso) 
(conclusão)

"Para registrar as aulas, eu compro no começo do ano um caderno para cada matéria, porque eu acho que fica mais organizado e aí eu faço os registros que a professora passa. Eu anoto algumas coisas que ela fala, que não está escrito na lousa, por exemplo, eu anoto para lembrar. [...] para estudar, para registrar mesmo, eu não uso muito [o tablet], porque eu fico meio confusa."

(Valentina - grifos nossos)

"Hoje em dia, eu uso caderno normal de dez matérias e eu costumo ir fazendo os resumos para as provas nesse caderno, só que já foi diferente. No começo desse ano a gente fazia as anotações na aula, o que era melhor na minha opinião, os cadernos ficavam separados. Hoje em dia, eu acabei comprando um caderno único e acabo fazendo todos os resumos pra prova no mesmo, só que também foi diferente do ano passado. No ano passado eu usava essas fichas, sabe? Mas hoje em dia eu faço tudo no caderno de dez matérias. [...] Eu acho que é uma coisa de hábito mesmo, sabe? Eu me acostumei a fazer desse jeito. Nas aulas da $[\ldots]^{31}$ ela usa um aplicativo bem legal e tudo. Eu até baixei ele, mas só usei para testar, eu queria explorar, só que eu prefiro fazer no caderno mesmo por uma questão de hábito."

(Lorena - grifos nossos)

Fonte: Elaborado pela Autora (2021).

Também é possível verificar o modo como Roberta faz seus resumos durante seus estudos (Figura 6). Em uma mesma ficha, registra todas as informações referentes a certa disciplina, utilizando cores para destacar e separar conteúdos diferentes. É interessante notar que o elemento que mais chama atenção na ficha, que foi escrito com a letra maior, é o período ao qual ela pertence, $4^{\circ}$ bimestre. A fim de privilegiar a otimização de espaço, ela faz seus registros de modo que preenche todas as linhas completamente, além de não as pular. Bastante diferente dos registros de Valentina (Figura 7), que ocupa o espaço do papel de outra maneira, com um título bem menos destacado quando comparado ao da aluna anterior, pulando linhas entre os blocos de conteúdo e exemplos, fazendo marcações e setas, escolhendo diferentes cores de destaque e marca-texto, com avisos para ela mesma, como: “Atenção!!!”. De outro modo, a partir da imagem do registro de Lorena (Figura 8), percebe-se que o destaque é atribuído ao título, enquanto o conteúdo é distribuído em duas colunas com duas cores, sendo uma para destaque de informações, além do uso setas e colchetes para organizar as informações.

\footnotetext{
${ }^{31}$ Por questões éticas, suprimiu-se o nome da professora de Língua Portuguesa.
} 
Figura 6 - Ficha com anotações da Roberta

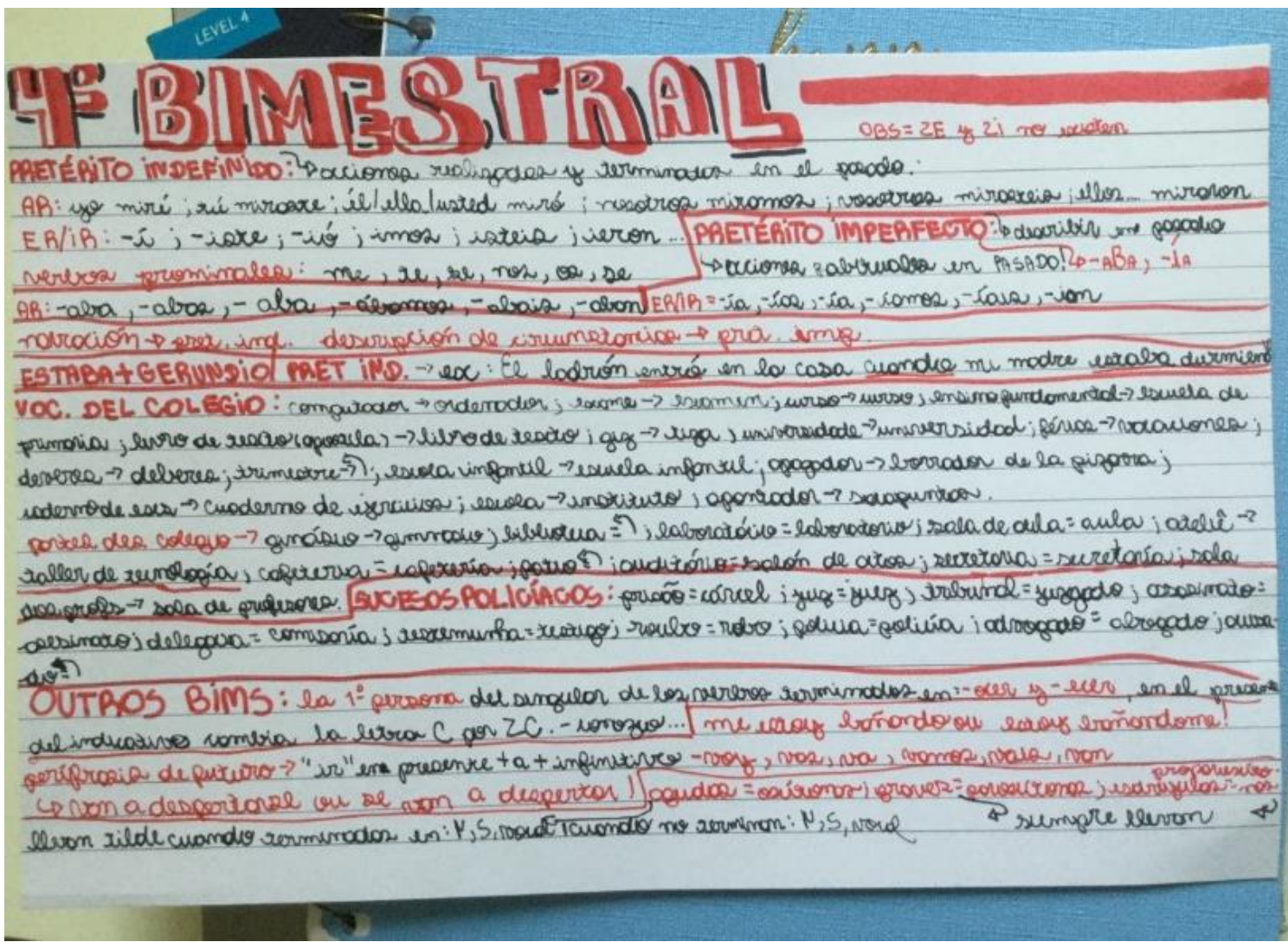

Fonte: Dados desta pesquisa (2021). 
Figura 7 - Caderno da Valentina

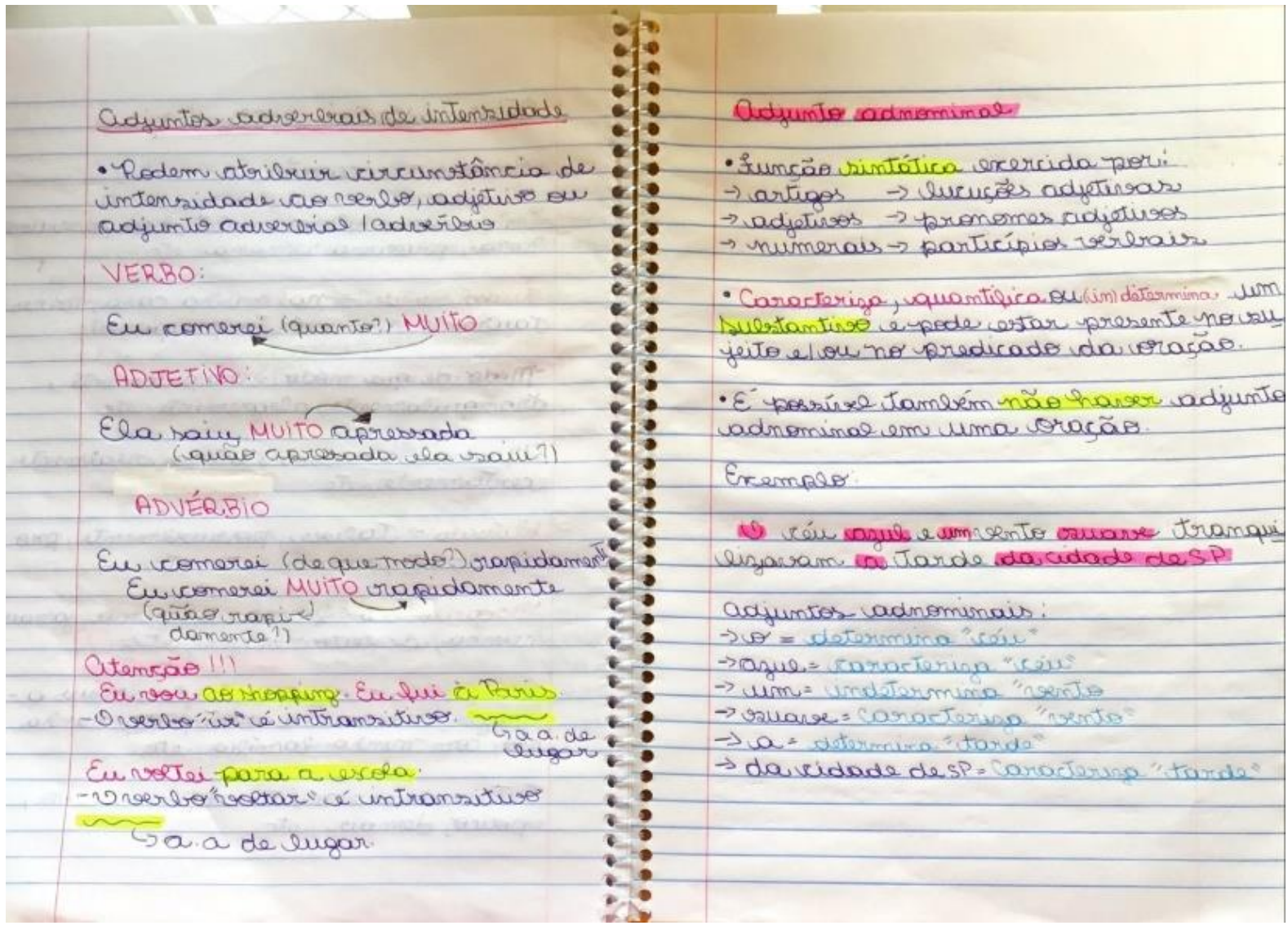

Fonte: Dados desta pesquisa (2021).

Figura 8 - Caderno da Lorena

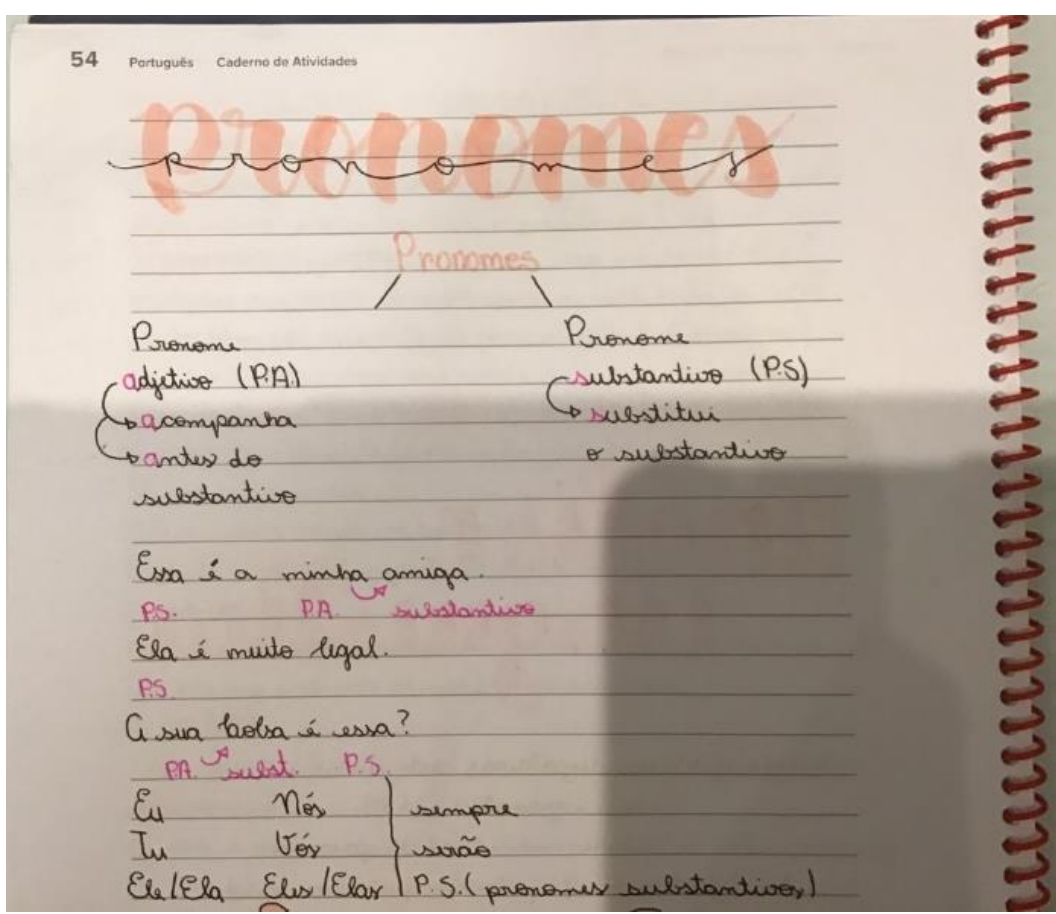

Fonte: Dados desta pesquisa (2021). 
Diante desses dados, verifica-se com intensidade a importância da dimensão do sujeito trazida pelo octógono. Apesar de a escola permitir o uso de suportes digitais, de se estar em um contexto remoto e ouvir-se frequentemente como adolescentes apelam para esses recursos, não é verdade que eles são unanimidade quando considerados como suportes de escrita. Dessa amostra, tem-se metade dos alunos que prefere os tablets, e a outra parte que, embora tenha experimentado e feito algumas tentativas, prefere o papel. E, somente considerando estes, há também diferenças, pois Lorena prefere escrever em um único caderno, Valentina tem um caderno para cada componente curricular, e Roberta faz resumos em fichas.

Essa dessemelhança de materiais revela que, por meio deles, os seus donos são capazes de mostrar também a sua personalidade. Sem considerar a perspectiva de escolha entre o papel e o digital, Oliveira (2008) já apontava que os cadernos escolares tornam possível a expressão do que é individual, posto que cada estudante "se coloca à sua maneira quando decide como enfeitará ou não seu caderno. Põe nele a marca de sua individualidade, de seu estilo, de seus gostos e modos de estar no mundo. Traz para a cena elementos de sua identidade cultural" (OLIVEIRA, 2008, p. 132). Dessa forma, os alunos conseguem expressar seus critérios, ideias e valores por meio de seus cadernos. Segundo a pesquisadora, é possível observar, nesse material, a pluralidade de cada um.

Nessa direção, Mignot (2008c) teve contato com as grandes empresas caderneiras, as quais reiteraram a ideia de que os cadernos escolares expressam a personalidade de seus donos. Em uma pesquisa feita para uma dessas empresas, com base em uma amostra de jovens, as capas dos cadernos retratavam a personalidade, refletiam as sensações, os valores os e sentimentos e estavam associadas à expressão da individualidade do usuário. Outra empresa afirma que o caderno que o estudante segura em suas mãos é como se fosse o seu outdoor. Fica claro, portanto, que, além da personalidade, os cadernos escolares expressam a individualidade do aluno, tanto estética (relacionada à capa) quanto intelectualmente (referente ao uso).

A dimensão do sujeito também se evidencia na medida os alunos que preferem o papel e os que preferem o digital, ambos justificam a sua predileção motivada pela organização das ideias e dos pensamentos. Uma das alunas, a Lorena, aponta para a questão do costume e do hábito; a Valentina e a Roberta declaram uma certa confusão no digital, o que se leva a refletir sobre como as experiências anteriores constituem os sujeitos e acabam por influenciar suas escolhas e sobre a necessidade de ensinar e formar os alunos para que aprendam a usar os recursos digitais e possam fazê-lo com autonomia. Durante a coleta dos dados, constatou-se que o colégio possui um projeto formativo nesse sentido, de modo que os funcionários do departamento de tecnologia da educação ensinam como utilizar algumas ferramentas e 
programas, como Agenda Google e Power Point. Contudo, essas falas indicam que, possivelmente, essa formação seja insuficiente para alguns alunos, pois ainda gera dúvidas e confusão no uso. Ademais, não foi considerada uma formação específica para o uso dos tablets como espaço de registro pessoal dos estudantes.

À parte o exposto, um aspecto que todos os alunos disseram que mudou em relação aos suportes no ensino remoto foi a resolução de exercícios em folhas avulsas. Antes, eles estavam acostumados a receber essas atividades na escola ou a imprimir, fazer a atividade no próprio papel e entregar para o professor. Nesse contexto de ensino remoto, todos pararam de imprimir, começaram a fazer diretamente no IPad e a devolver ao professor via Moodle ou e-mail. Tal alteração visa a otimização do tempo, pois os alunos deixam de ter que baixar o arquivo, imprimir, responder, fotografar e anexar, passando a baixar o arquivo, responder e anexar. Esse aspecto não é valorizado só pela organização didática e escolha dos professores, como verificado no octógono das dimensões dos suportes de escrita, mas também pelos estudantes, conforme notado nas entrevistas.

No que se refere ao que os alunos registram em seus cadernos, são muitas as possibilidades: cópias, anotações pessoais, registro daquilo que se considera mais difícil e complexo, roteiros, esquemas, mapas mentais, anotações extensas que se assemelham a transcrições de aula, resumos com itens mais relevantes, palavras-chave. De acordo com os próprios alunos:

Quadro 10 - Excertos das falas dos alunos sobre o que anotam em seus cadernos

(continua)

"Pra mim depende um pouco da matéria. Tem algumas matérias que os professores antes do ensino a distância já pediam para a gente registrar, então como fazia parte do curso, eu optei por continuar registrando e copiando dos Power Points, porque, na minha visão, os professores tinham algum motivo para pedir, já que eles já disponibilizavam os Power Points. Então, para a minha fixação eu anoto de algumas matérias os Power Points, mas para estudar mesmo eu pego basicamente todas as informações que a gente tem e vou fazendo as anotações para eu entender mesmo a matéria. Então são esses dois principais."

(Gabriela)

"Pra mim depende um pouco da matéria, por exemplo, em História, meio que tinha um roteiro que a gente copiava e isso eu continuei. Mas em matérias como Geografia ou Matemática, tem algumas coisas que não estavam nas fichas de estudo ou que estava na videoaula e eu achava interessante, eu ia anotando no caderno e mais tarde eu passo pro IPad. Eu vi que os professores deixam mais livres agora." 
(conclusão)

"Depende da matéria. Nas matérias que eu tenho mais dificuldade, eu costumo anotar quase tudo o que a professora fala na aula. As que eu tenho menos eu não costumo anotar tanta coisa, eu nem anoto, às vezes."

(Julia)

"Eu registro um resumo, só que bem explicadinho de cada tópico que a gente aprendeu. Eu não fico colocando muitos exemplos. Eu coloco um exemplo a cada tópico que a gente aprendeu, faço bastante esquema também, mas eu prefiro escrever ou em tópicos ou um texto mesmo e ir grifando as partes mais importantes."

(Valentina)

"Antes eu fazia um resumo grande, nem sei se podia ser chamado de resumo. Era um resumo grandinho. Só que na quarentena eu comecei a fazer tanto resumo mais tanto resumo que eu peguei o jeito e agora diminuiu e agora eu acho muito mais fácil. Eu pego a matéria muito mais fácil fazendo resumo. Eu tenho uma caixa de resumo."

(Roberta)

"Isso é uma coisa que eu acho que eu tenho que melhorar, é uma coisa que com o tempo talvez eu consiga, tendo prática. Eu tenho muita dificuldade em separar o que é muito importante do que não é tão importante."

Fonte: Elaborado pela Autora (2021).

(Lorena)

Essa diversidade de modos de registro fica evidente ao se observar as fotos dos cadernos (Figuras 9 a 18), assim como já assinalado no octógono das dimensões dos suportes de escrita no que tange à relação do registro com a área do conhecimento. Isso porque, quando se analisa as imagens dos cadernos dos diferentes alunos com registros do mesmo conteúdo, dado na mesma aula e pelo mesmo professor, tem-se universos particulares. Se alguém desavisado fizesse uma observação mais rápida, sem conhecer esses cadernos, talvez afirmasse que fossem registros de alunos de diferentes escolas, uma vez que o conteúdo é o mesmo. Na verdade, é a forma do registro que é bastante diversa, como mostram as imagens dos cadernos de Geografia, a seguir, cujo conteúdo é a região Sudeste brasileira. 
Figura 9 - Anotações de aula sobre Região Sudeste do Tomás (Parte 1)

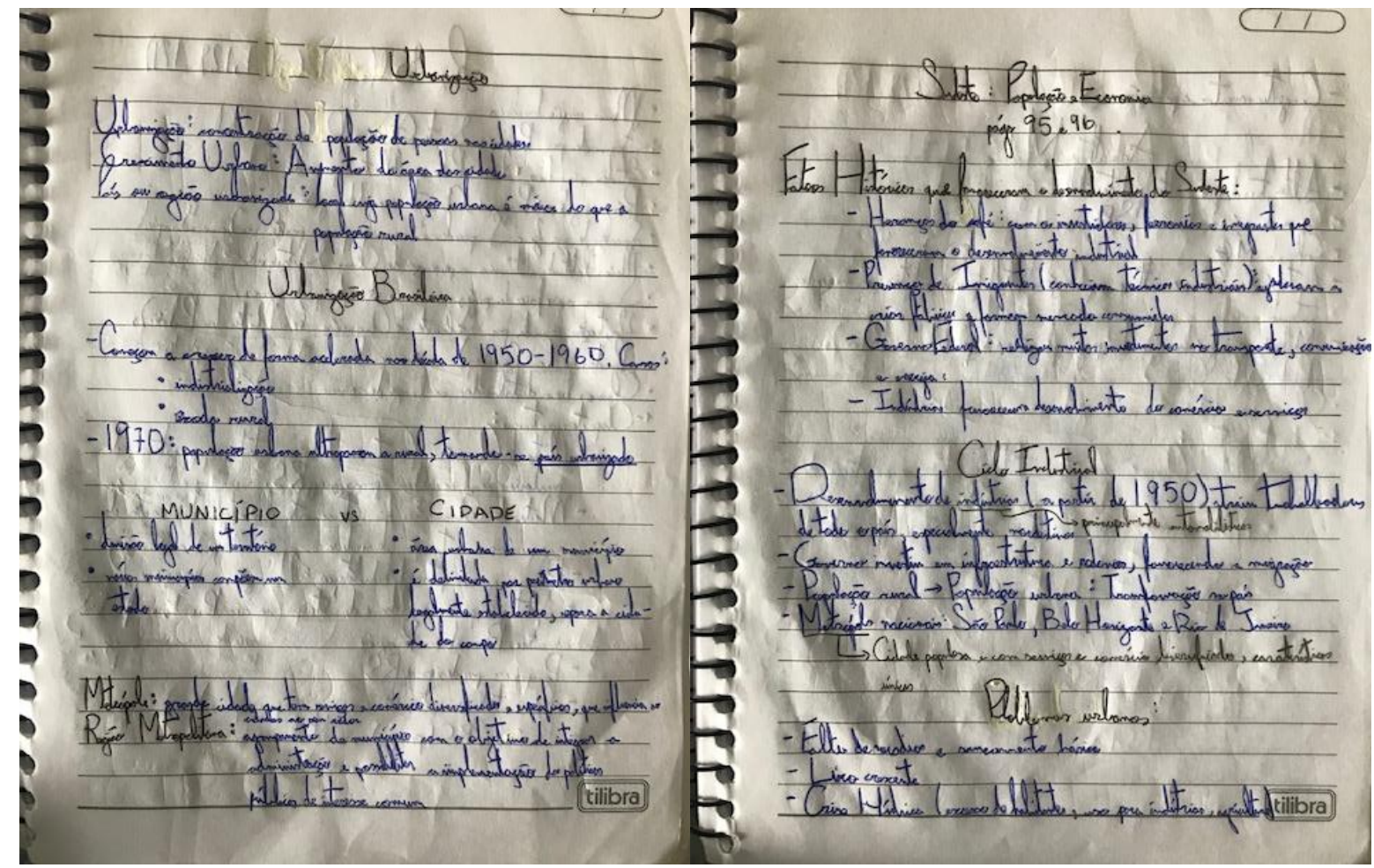

Fonte: Dados desta pesquisa (2021).

Figura 10 - Anotações de aula sobre Região Sudeste do Tomás (Parte 2)
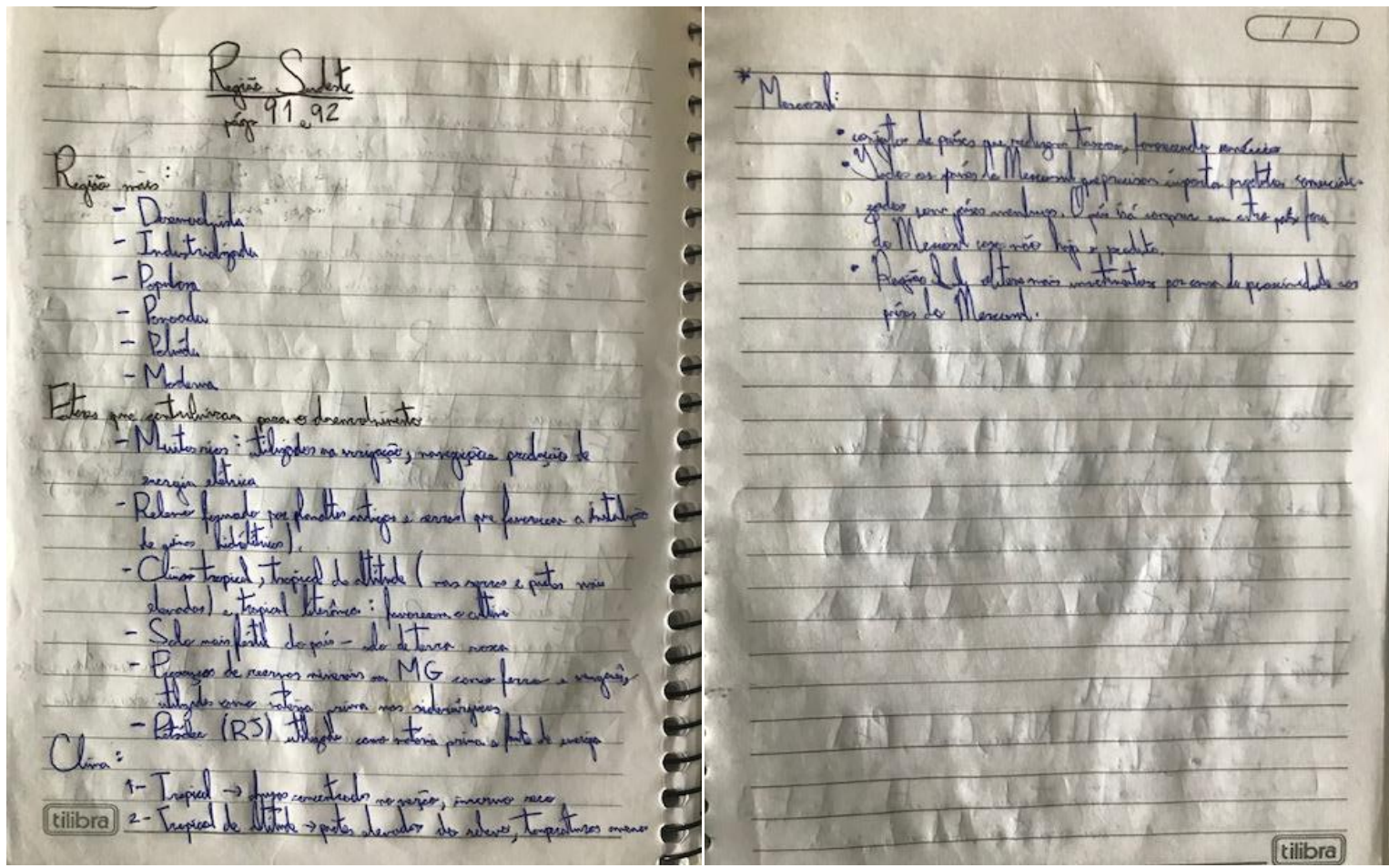

Fonte: Dados desta pesquisa (2021). 
Figura 11 - Anotações de aula sobre Região Sudeste do Tomás (Parte 2)

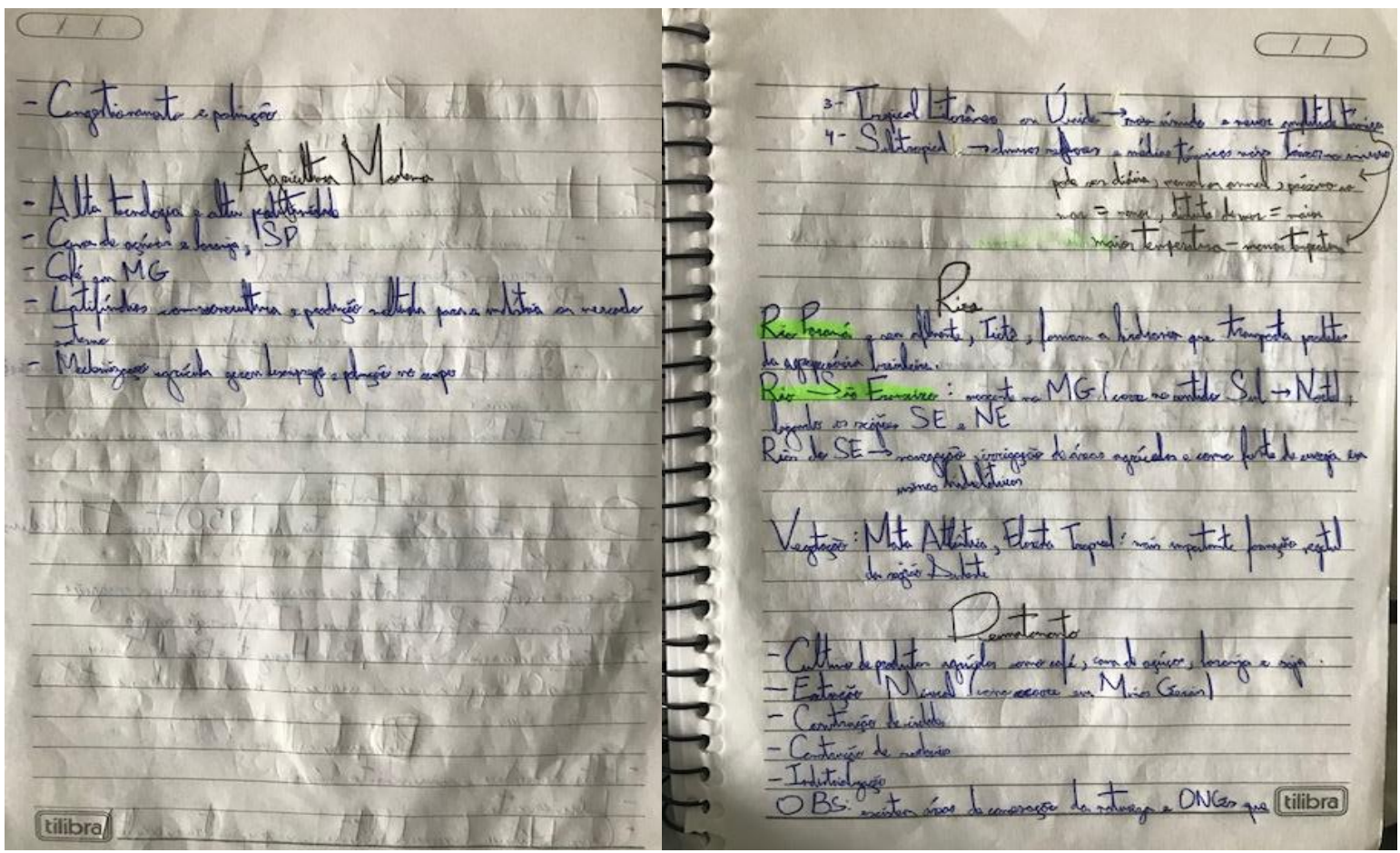

Fonte: Dados desta pesquisa (2021).

Figura 12 - Anotações de aula sobre a região Sudeste da Gabriela (Parte 1)

$$
04.09 .20
$$

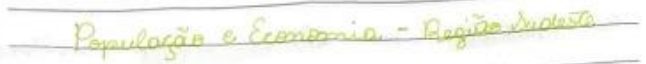

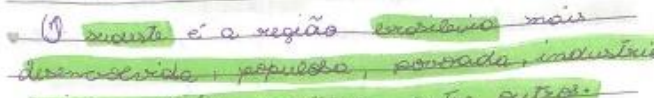

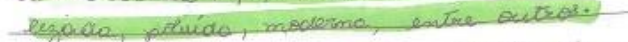

Eare acoroclarmente se as por conta de

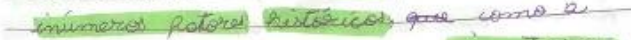

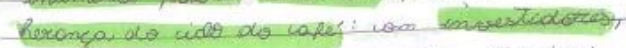

as fextentes e of vinigromoter, traziolos

pora cá por conto do depel, assinas

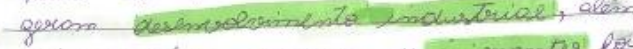

dusig tombin a ressincio da Lamigromites let

de suma smportóncia, yá que eles

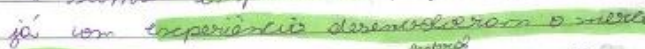

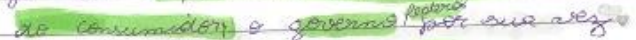

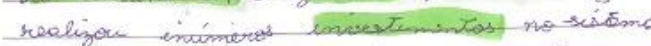

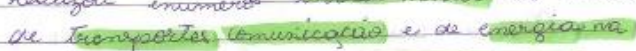

regiais, por fin exs elesencsehviments

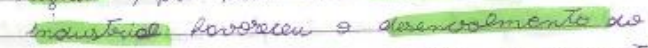

womercis e de semest embromat que estes

sois os principais lowras exirtem enwmorar

ontros.

Cos inolustruas se alesenververom a partir.

Qhe 1950 , hoto que atracu trueluglrudores de

voolo pass, especiomento do nordeste.

Crsim a poverno pusso a imuestit
}

03.09 .20

Fonte: Dados desta pesquisa (2021). 
Figura 13 - Anotações de aula sobre a região Sudeste da Gabriela (Parte 2)

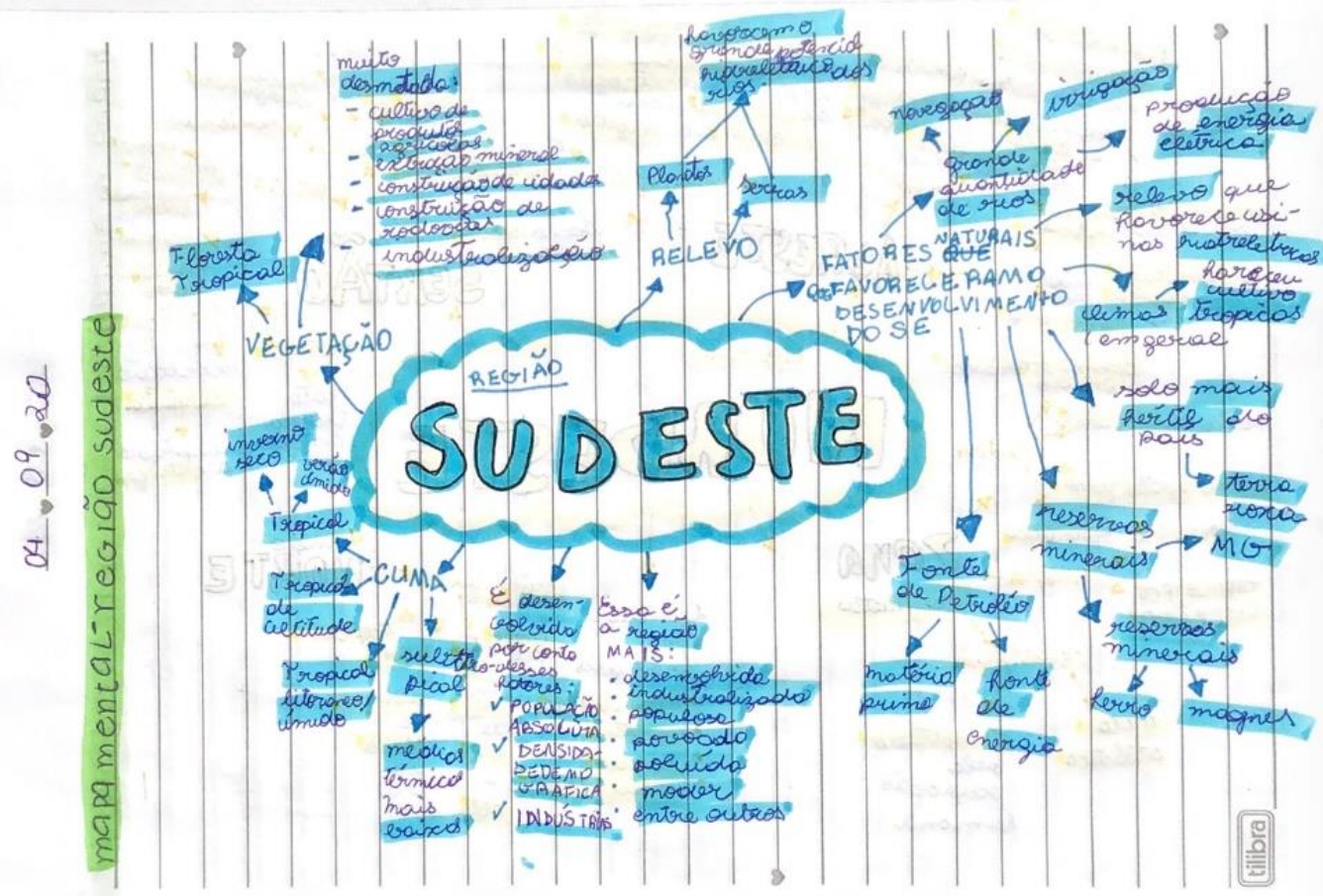

Fonte: Dados desta pesquisa (2021).

Figura 14 - Anotações de aula sobre a região Sudeste da Valentina

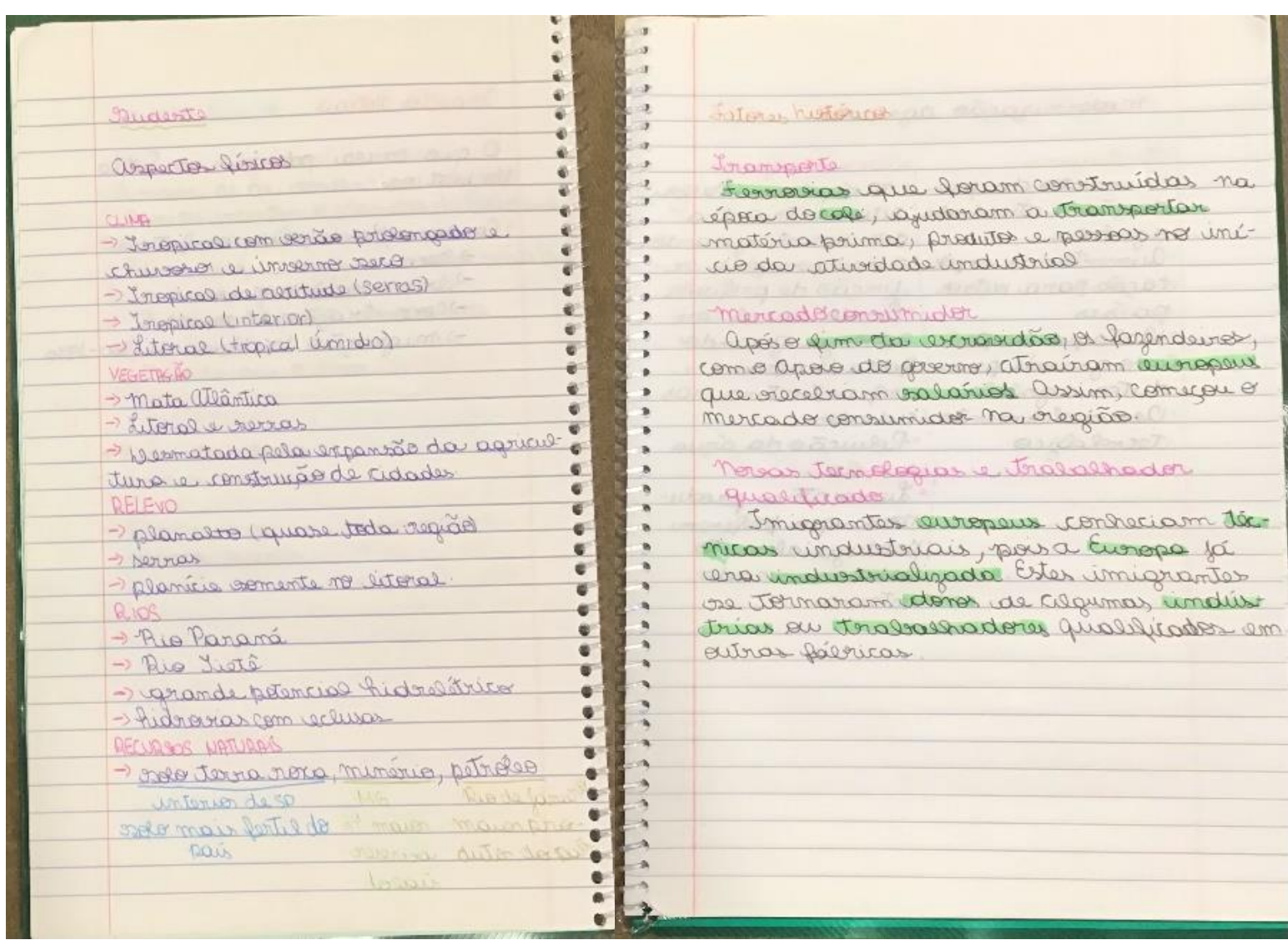

Fonte: Dados desta pesquisa (2021). 
Figura 15 - Anotações de aula sobre a região Sudeste da Roberta

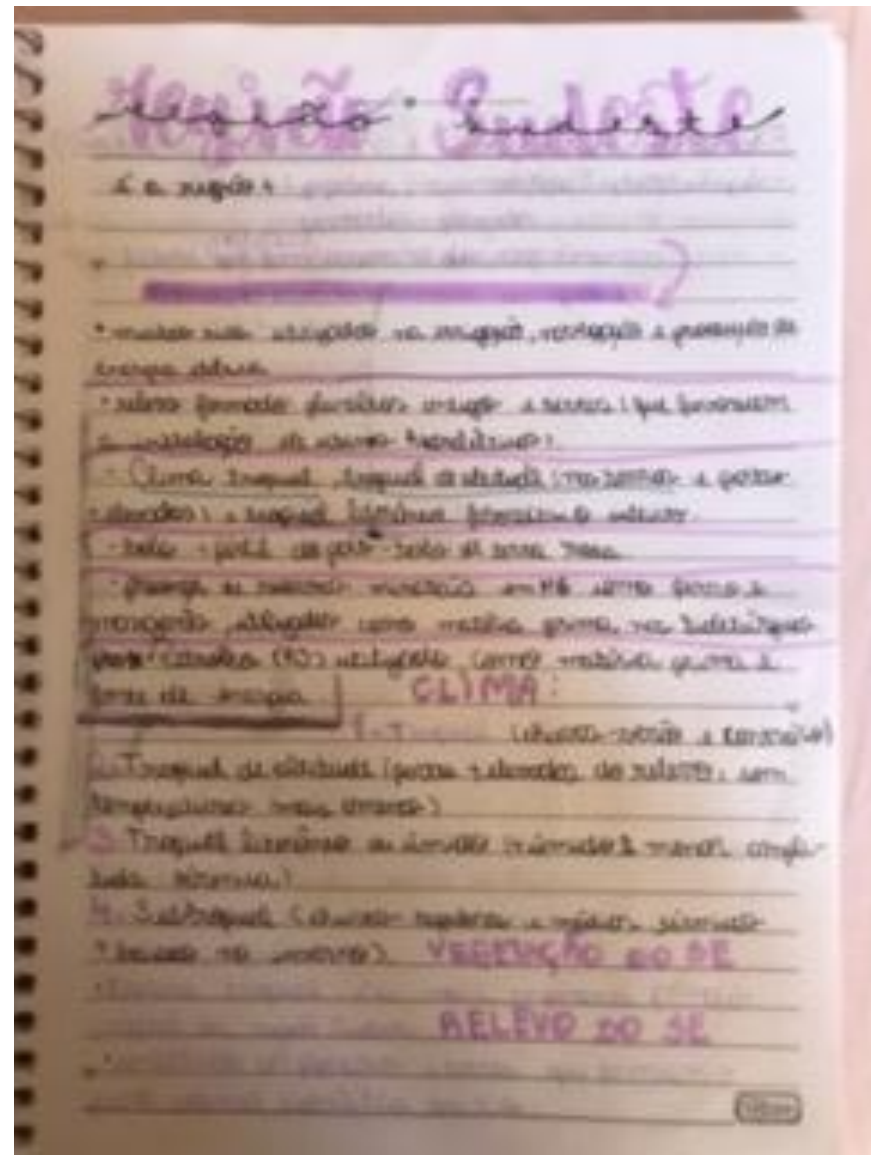

Fonte: Dados desta pesquisa (2021).

Figura 16 - Anotações de aula sobre a região Sudeste da Lorena (Parte 1)

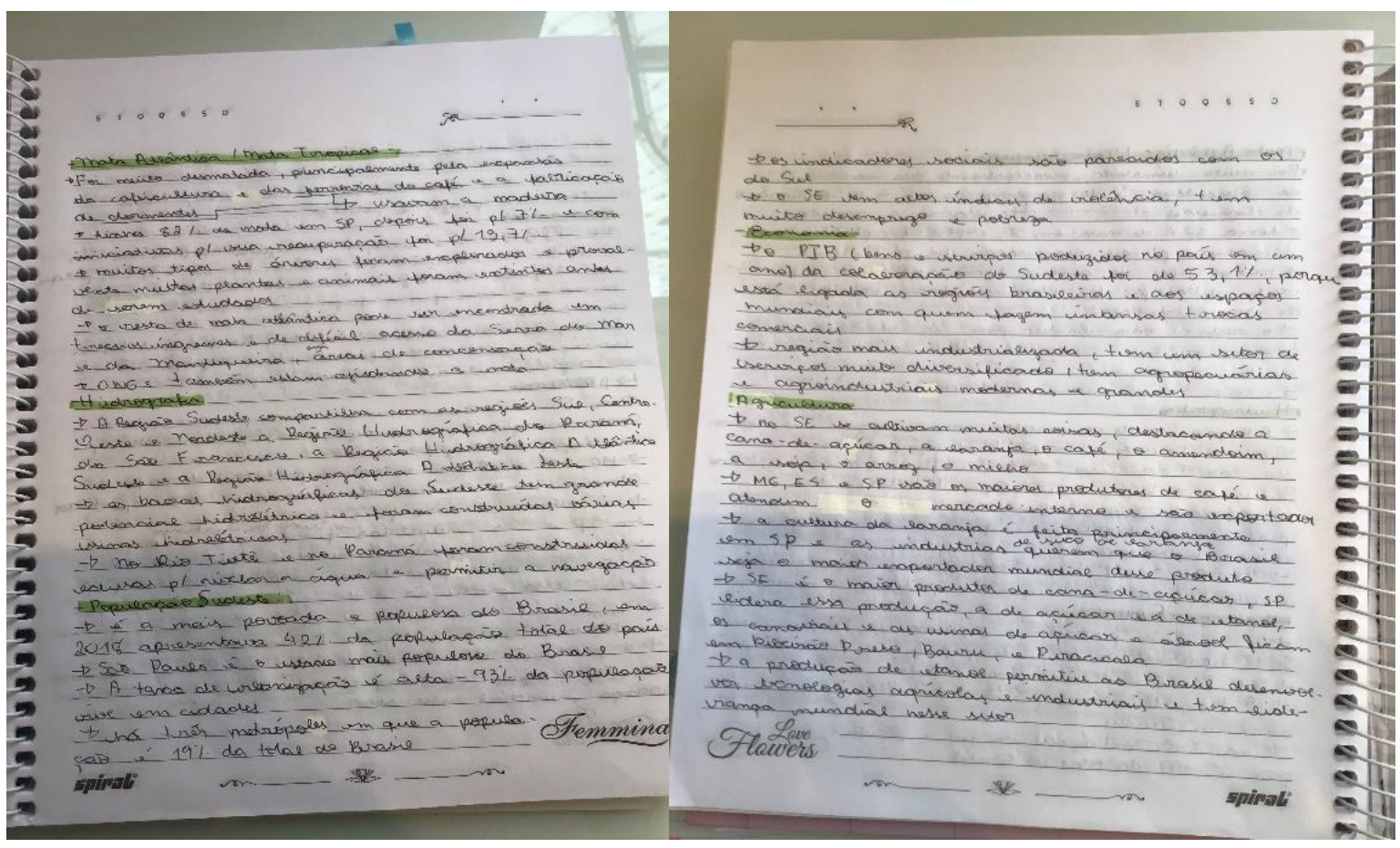

Fonte: Dados desta pesquisa (2021). 
Figura 17 - Anotações de aula sobre a região Sudeste da Lorena (Parte 2)

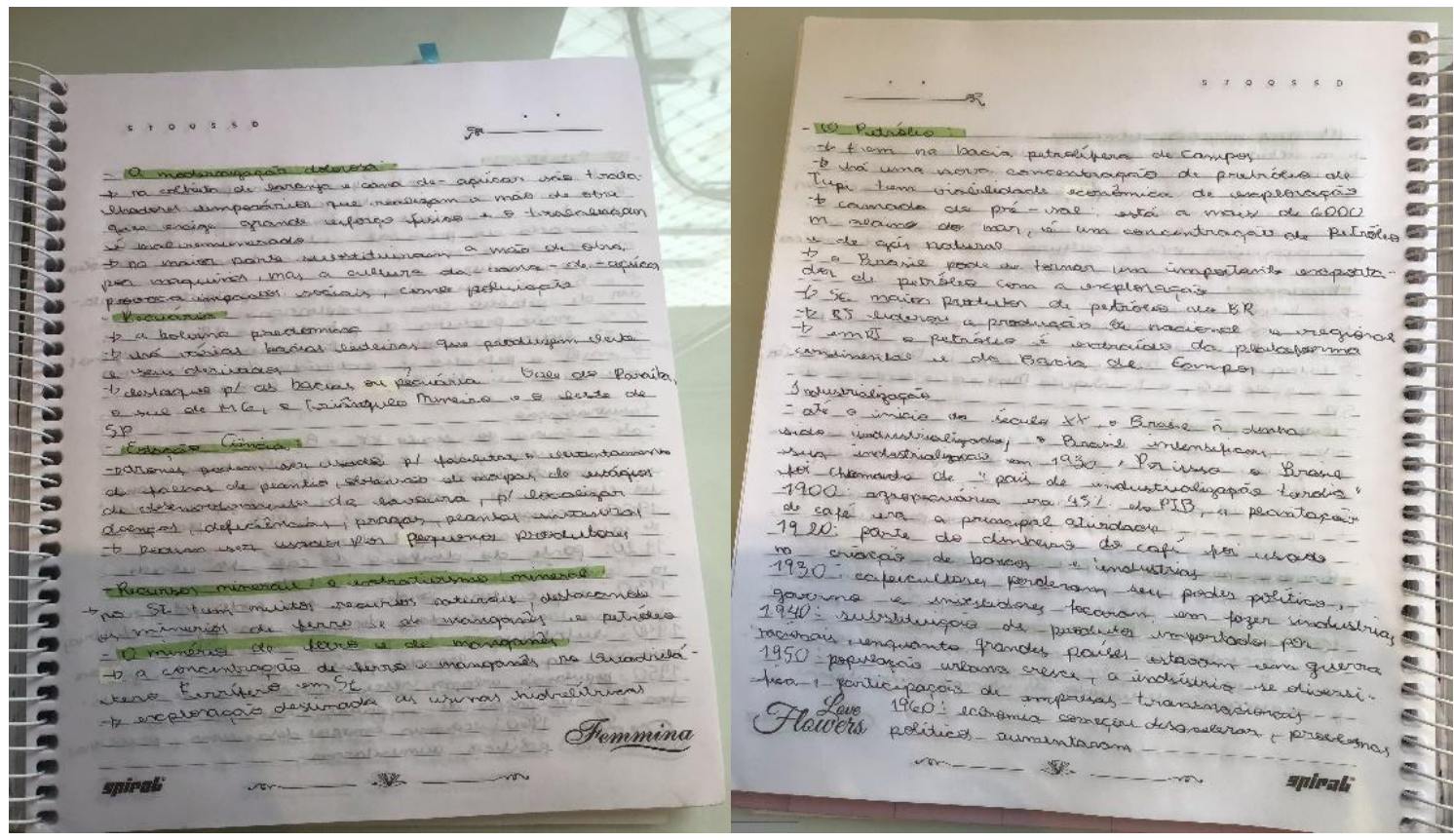

Fonte: Dados desta pesquisa (2021).

Figura 18 - Anotações de aula sobre a região Sudeste da Lorena (Parte 3)

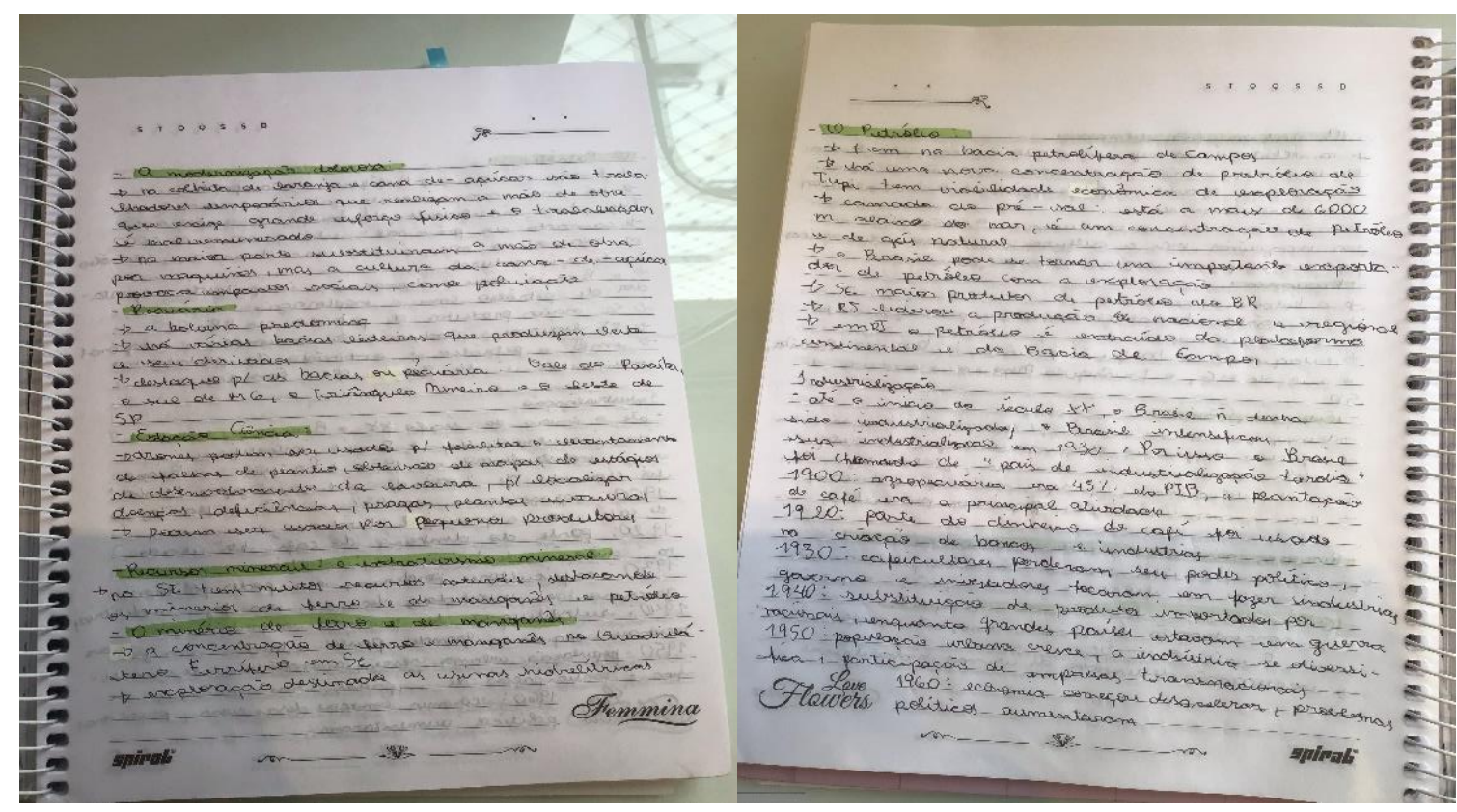

Fonte: Dados desta pesquisa (2021).

As Figuras 9, 10 e 11 evidenciam que Tomás faz seus registros, destacando de cor diferente o subtítulo, como economia, política, clima, anotando em forma de itens, em seguida, as informações relativas ao assunto. Já Gabriela (Figuras 12 e 13), escreve, primeiramente, em formato de texto, depois destaca com marca-texto aquilo que ela considera relevante, criando um mapa mental a partir disso. No que diz respeito a Valentina (Figura 14), mescla os dois 
formatos apresentados anteriormente; ora ela registra de maneira parecida com Tomás, escrevendo o subtítulo colorido e as informações relacionadas ao tema em itens, ora faz o subtítulo desse mesmo jeito, registra um pequeno texto e destaca algumas palavras-chave que considera mais relevante. Roberta (Figura 15), por sua vez, também escreve em forma de tópicos, desenvolvendo mais o texto, de modo que não escreve apenas palavras-chave. Essa aluna também cuida da estética de maneira diferente, fazendo uso da técnica de lettering, isso é, cuidando do desenho das letras do título ao invés de somente escrevê-lo, quando se percebe a escolha intencional de uma única cor, o lilás, para destacar o que considera importante. Não obstante, Lorena (Figuras 16, 17 e 18) faz todas as suas anotações de uma mesma cor, destacando apenas os subtítulos. Ela também escreve em forma de itens, porém com muito mais informações, se assemelhando a uma transcrição da aula, confirmando a dificuldade de selecionar para registro aquilo que é central, como ela mesma afirma. Infelizmente, não se teve acesso às imagens do caderno da Julia com esse conteúdo. Ela enviou, no entanto, imagens de outros assuntos, sendo possível observar que seus registros se dão em formato de esquemas bastante coloridos e com a presença de ilustrações.

Figura 19 - Anotações de aula sobre as reformas religiosas da Julia

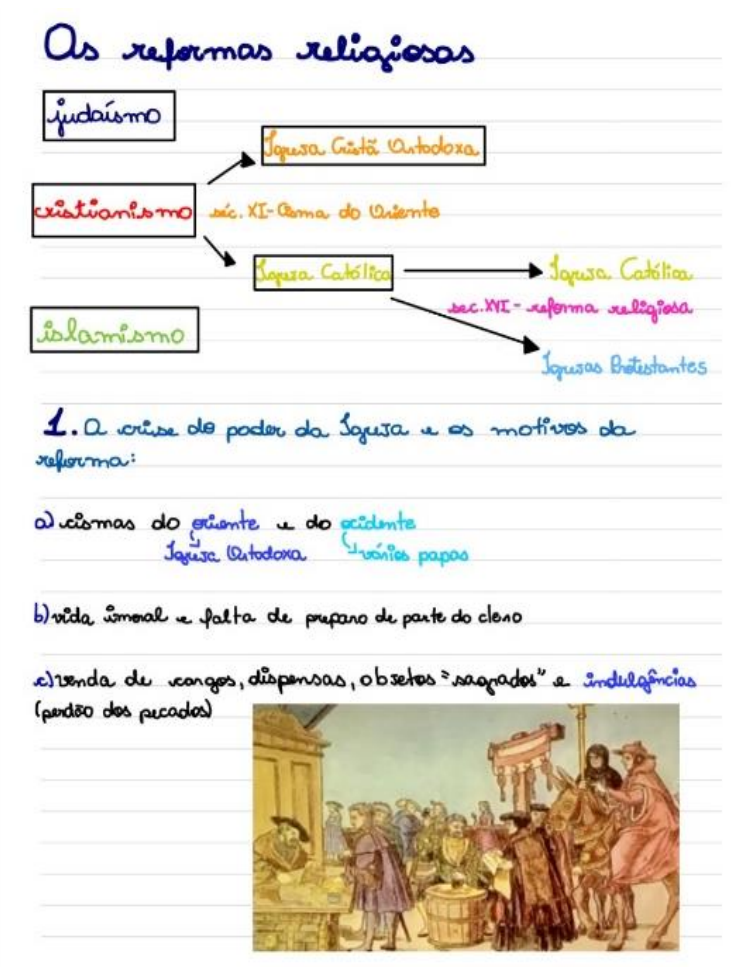

Fonte: Dados desta pesquisa (2021).

Portanto, nota-se que há modos pessoais de apropriação do conhecimento, já que se observa que não há um consenso entre os registros. Em certos momentos, os alunos lançam 
mão da cópia, justificando que essa era uma solicitação de alguns dos professores em determinadas partes de aula e, se antes havia essa orientação, é porque deveria ser fundamentada, ou seja, acreditando que há intencionalidades pedagógicas que amparam tal orientação. Por essa razão, ainda que o uso do caderno no ensino remoto não seja inspecionado pelos professores - e na lógica das videoaulas nem sempre há esse tipo de recomendação -, os alunos permanecem copiando nas disciplinas em que isso era solicitado. Percebe-se, também, que, em outros momentos, eles fazem registros mais autorais, tomando nota daquilo que acham interessante ou mais complexo, privilegiando os conteúdos mais desafiadores. Ainda, há alunos que preferem fazer registros em formato de tópicos ou itens, outros que fazem resumos, e duas alunas que assinalam a dificuldade em discernir aquilo que é relevante de ser anotado, acabando por anotar tudo o que podem.

Essas variações também acontecem levando em consideração o mesmo aluno diante dos diferentes componentes curriculares. A maior parte deles deixa claro que suas anotações variam de acordo com a disciplina, como já fora apontado com uma das dimensões do octógono. Portanto, pode-se dizer que o presente estudo encontrou resultados similares aos da pesquisa etnográfica de Oliveira (2008), em que ela constatou que, ao contrário da ilusão que se tem de homogeneidade, os escritos dos cadernos diferem entre as crianças da mesma turma. Há diferenças em anotações, como nas datas e nos conteúdos anotados e divergências na estética.

Interessante também refletir sobre os formatos dos registros. A aluna, Julia, que faz uso do suporte digital, produz esquemas, utiliza diferentes cores (é o caderno mais colorido) e frequentemente adiciona ilustrações do assunto. No entanto, como se observou nas figuras, ainda que se considere somente o suporte de papel, os alunos escrevem seus registros em diversos formatos, por vezes, sem respeitar as linhas e, até mesmo, alterando a lógica do formato da página de retrato para paisagem. Desse modo, a grande potencialidade e a diferença entre um tipo de suporte e outro dentre esses alunos fica a cargo da possibilidade de edição. Uma vez que não necessitam apagar todo o trabalho para inserir imagens e ilustrações, tornase mais fácil pensar em diferentes formatos justamente por ser mais prático inserir e mover itens, como afirma Julia: “Agora eu tenho imagem, eu tiro print da aula e coloco, fica mais legal de estudar por elas. Às vezes eu tiro print do vídeo, do Power Point, às vezes eu pego da internet, depende.".

Gabriela, que, similarmente, faz anotações posteriores à aula no IPad, também menciona maior facilidade em pensar em registros de diferentes formatos no suporte digital:

No IPad eu sinto que eu consigo soltar um pouco mais a minha criatividade no quesito de usar mais cores, colocar mais desenhos, mais imagens, [...] mais 
coisas gráficas mesmo. Acabo fazendo mais desenhos e eu acho que visualmente eles ficam mais organizados, porque se eu errar eu não preciso rasurar, eu apago. Eu acho que isso deixa mais bonitinho visualmente. (Gabriela).

Pode-se pensar em outras possíveis potencialidades do suporte digital, como a utilização de: fotos das lousas, tiradas pelos alunos; capturas de tela das videoaulas, para fazer registros a partir delas; gravação de áudios dos próprios alunos sobre conceitos mais importantes; inserção de vídeos que ilustrem o assunto; cópia e colagem das atividades relativas ao conteúdo junto com as anotações mais teóricas, entre outras. Isso porque como as pesquisas vêm mostrando, aprender no contexto digital acontece de novas formas, a começar pelas estratégias de leitura. Segundo consta na coleção desenvolvida pelo Centro de Estudos e Pesquisas em Educação, Cultura e Ação Comunitária (CENPEC), diferentemente do que ocorria antes desse contexto, a leitura não acontece de modo linear e exige a "compreensão de caracteres semânticos nas quais símbolos e ícones compõe o ‘texto’ a ser lido, interpretado e compreendido.” (ALTENFELDER et al., 2011, p. 10). Tal efeito se deve a essa geração estar inserida em um mundo multimídia, no qual toda tela é colorida, composta por múltiplas imagens, frequentemente com movimento e som, com a presença de hipertextos que permitem conexão com outras páginas, conteúdos, imagens e textos. Assim, "o que muitos adultos enxergam como sobrecarga de informação, a nova geração entende como diversidade e riqueza" (ALTENFELDER et al., 2011, p. 10). E, por esses estudantes serem expostos e inseridos desde o nascimento nas tecnologias digitais, acabam criando estratégias de leitura e, por conseguinte, de escrita e de modos de se organizar e aprender adequados às suas necessidades.

Outro aspecto importante de ser evidenciado no que se concerne aos modos de registro é que todos os estudantes afirmaram terem mudado sua forma de registro durante as aulas remotas; seja porque antes estavam mais presos ao que os professores escreviam na lousa e, com as aulas online, escrevem com mais autonomia, ou pelo simples fato de que, com videoaulas, os estudantes podem voltar e rever diversas vezes as aulas. Tal possibilidade altera a dimensão do tempo e do espaço, uma vez que, na escola, a aula acontece durante aqueles minutos específicos e, portanto, os registros de aula também ficam limitados àquele tempo e espaço. No entanto, com as aulas sendo ministradas por meio de vídeos, há outros tempos: os alunos podem ver e rever as aulas quantas vezes quiserem e considerarem necessário, voltar e assistir uma parte específica que não tenham compreendido ou na qual tenham tido dúvida, podendo isso acontecer de qualquer lugar, em qualquer horário, de manhã, à tarde ou à noite.

Ademais, também levando em consideração os tempos, foi salientada por alguns alunos a busca pela praticidade em seus registros, visando a otimização do tempo durante esse modelo, 
conforme já assinalado. Dessa forma, uma das alunas menciona que deixou de privilegiar a estética das anotações, deixando de usar tantas cores e primando pela rapidez:

no começo do ano eu costumava fazer meus resumos mais bonitinhos, sabe? [...] fazia um título mais elaborado, até lettering, mas olha esse de agora, [mostra o registro] mais básico. Eu não sei o que aconteceu na quarentena, eu acho que eu comecei a considerar mais a praticidade e fui só fazendo, não tão bonitinho como eu fazia antes. (Lorena).

Alguns alunos enfatizaram que, com as aulas remotas, sentiram a necessidade de estudar e registrar mais conteúdos, pois perderam as referências daquilo que os professores apontavam como sendo mais essencial e, sem esse parâmetro, preferem anotar tudo o que podem. Com relação a isso, sinaliza Valentina: "Eu acho que agora que a gente tem acesso às aulas tem mais coisa para escrever, retomar e fixar mais na cabeça. [...] Eu anoto mais coisas agora, mas sempre anotei bastante coisa para estudar.". Algo semelhante foi relatado por Tomás:

Eu vi que os professores deixam mais livres agora. [...] Foi bem legal essa parte da liberdade, mas também deixa o tema mais variado. Então, por exemplo, vai ter uma prova, você copia automaticamente mais do que se pede. Então acho que você ganha mais conteúdo pra você, mas é ruim, de certa forma, porque você tem mais temas para estudar.

A fala desses dois estudantes volta-se para a questão da autonomia da escrita, ou seja, mostra que estavam acostumados a terem alguém - os professores nesse caso - que diziam o que era importante de ser anotado e o que era menos relevante. Quando os docentes, por ocasião das aulas remotas, deixam de sinalizar e orientar para essa questão, os alunos sentem-se perdidos e com dificuldade de compreender os pontos centrais dos objetos do conhecimento.

De modo inverso, esse mesmo contexto possibilitou o exercício dessa autonomia e proporcionou que uma das alunas conseguisse privilegiar suas anotações pessoais daquilo que ela mesma considerava essencial. Em suas palavras: "Antes a gente copiava o que os professores escreviam ou colocavam no Power Point, só que na quarentena eu comecei a fazer as minhas anotações, eu ouvia a aula e ia escrevendo o que eu achava importante." (Lorena).

Paulo Freire (1996), antes mesmo de considerar qualquer aparato tecnológico de informação e comunicação, já apresentava propostas de práticas pedagógicas que visavam a construção da pedagogia da autonomia. Mostrou que ensinar não é transferir conhecimento, entendendo este ato como a capacidade de o professor criar possibilidades para a construção e a produção do conhecimento por parte dos alunos. Estes, por sua vez, assumindo-se como seres históricos e sociais, que pensam, opinião criticam e dialogam. Dessa forma, nesse contexto em que há tanto acesso à informação de maneira tão diversificada, a função de ensinar é ainda menos exclusiva do professor, sendo primordial que se eduque, oferecendo instrumentos para a aprendizagem autônoma dos alunos. 
Outra mudança nos registros durante o contexto remoto foi evidenciada por uma das alunas e se refere ao aprendizado que advém do processo de se fazer várias vezes a mesma ação. Roberta mencionou que passou a escrever mais resumos durante as videoaulas e em seus estudos pessoais, e isso permitiu com que ela visse avanços nessa prática: “Antes eu fazia um resumo grande, nem sei se podia ser chamado de resumo. Era um resumo grandinho. Só que na quarentena eu comecei a fazer tanto resumo mais tanto resumo que eu peguei o jeito e agora diminuiu e agora eu acho muito mais fácil.” (Roberta).

Ao pensar na lógica diversa delineada pelas videoaulas, em que se permite que o aluno assista à aula diversas vezes em sua totalidade ou em partes, incorre-se em outro fator que se relaciona aos registros: guardar as informações. Ou seja, parte-se da ideia de que se escreve nos cadernos, digitais ou analógicos, para se armazenar a aula e poder retomá-la em outros momentos. Porém, com as videoaulas e a possibilidade de reassisti-las quantas vezes se desejar, perde-se a finalidade do registro no caderno como guarda dessas informações. Tal reflexão envolve, assim, a função do registro e das formas de aprender, temas tratados no próximo capítulo. 


\section{MODOS DE REGISTRO E FORMAS DE APRENDER: RELAÇÕES E SENTIDOS}

Neste capítulo, trata-se das formas de aprender dos alunos, analisando como os registros das aulas e as anotações pessoais nos suportes de escrita (analógicos ou digitais) apoiam e auxiliam essas aprendizagens, além de se verificar quais funções os estudantes atribuem a suas escritas, e de compreender a importância e a função dos cadernos de papel e dos tablets para os alunos ouvidos nesta pesquisa.

Durante as conversas com os estudantes, dos seis, quatro deles afirmaram que fazem suas anotações por escrito porque isso faz com que aprendam melhor, isto é, há uma adesão a ideia de escrever para aprender. Em suas palavras:

Quadro 11 - Excertos das falas dos alunos sobre a ideia de que quando escrevem aprendem melhor

\begin{tabular}{|lr|}
\hline $\begin{array}{l}\text { [...] Eu sou uma pessoa bem que precisa escrever e ver para entender e aprender. } \\
\text { (Gabriela) }\end{array}$ \\
\hline $\begin{array}{l}\text { Outra coisa do porquê eu não uso muito o IPad para fazer anotação, principalmente para a } \\
\text { prova, porque eu acho que digitando eu não fixo muito o conteúdo na minha cabeça. Então eu } \\
\text { acho que quando eu anoto, fica bem mais claro, eu entendo mais também. }\end{array}$ \\
\begin{tabular}{ll}
\hline [...] Hoje em dia eu costumo fixar bastante enquanto faço resumo. \\
\hline $\begin{array}{l}\text { Me dá a sensação de que eu estou escrevendo e nossa, eu estou memorizando e no IPad não dá } \\
\text { essa sensação. }\end{array}$
\end{tabular} \\
\hline
\end{tabular}

Fonte: Elaborado pela Autora (2021).

Pelas falas dos estudantes entende-se que há correspondências e aproximações entre aprender e memorizar, decorar ou fixar. No entanto, é preciso salientar que esta pesquisa leva em conta uma distinção entre esses termos, não sendo, assim, encarados como sinônimos. De acordo com o dicionário Houaiss (2008, p. 54-55), aprender tem três significados: "adquirir conhecimento (de)" ou "adquirir habilidade prática (em)" e, ainda, "ter melhor compreensão de (algo) pela intuição, experiência, convivência". Já memorizar segundo o mesmo dicionário quer dizer "trazer à mente; lembrar, recordar"; significa também "fixar na memória espontaneamente ou por métodos mnemônicos, decorar" (p. 497). Além disso, evocam-se as ideias de Philippe Meirieu (1998), nas quais aprender significa relacionar-se com o conhecimento de modo a apropriar-se dele, a partir de novas (re)significações atribuídas por cada sujeito da aprendizagem. Portanto, bem diverso de fixar, decorar ou memorizar qualquer conteúdo. 
Apesar da distinção entre os termos, é relevante analisar que os estudantes consideram o registro como uma estratégia para aprender mais e melhor. Como mencionou-se ao destacar o sujeito no octógono das dimensões, a escrita das anotações e dos registros de aula se relaciona com a identidade, a personalidade e os valores de quem escreve, de certo modo, até mesmo ativando memórias afetivas, sendo todos esses elementos estruturantes do ato de registrar de cada um. Por isso, não à toa, tem-se observado, nos últimos anos, um aumento significativo de crianças e adolescentes se dedicando a estudar a caligrafia das letras e usando a técnica do lettering em seus cadernos. A questão, porém, recai além de o que se registra, mas, principalmente, sobre o como se registra, impactando diretamente na escolha do suporte, foco desta investigação.

Nas falas dos alunos há a distinção entre o escrever e o digitar, afirmando que tais ações não são a mesma coisa, além de não sentirem que aprendem do mesmo modo em ambos os casos. Essa ideia combina com uma pesquisa norte americana The Pen Is Mightier Than the Keyboard: Advantages of Longhand Over Laptop Note Taking, de 2014, publicado por Pam A. Mueller da Universidade de Princeton e Daniel M. Oppenheimer Universidade da California, cujo próprio título evidencia que, para o aprendizado, é melhor anotar a mão do que digitar. Com uma amostra de 65 estudantes, o objetivo desse trabalho foi comparar quanto os alunos aprendiam usando o computador ou o papel. Para tanto, depois de os alunos assistirem algumas aulas, os pesquisadores fizeram perguntas mais objetivas e factuais e outras mais conceituais. Não houve diferença na taxa de acertos de quem fez anotações em papel ou no computador sobre as perguntas mais factuais. Todavia, nas questões relativas aos conceitos, o grupo que havia registrado em papel conseguiu mais êxito. Ainda, verificou-se algo semelhante quando a prova foi aplicada uma semana depois das aulas, e os estudantes podiam consultar suas anotações.

Todavia, não se trata de taxar os recursos digitais como vilões das aprendizagens. É fundamental ter clareza de o que e como os participantes da pesquisa estavam anotando no momento das aulas. As duas maiores diferenças observadas foram em relação ao número de palavras e às anotações literais, de modo que, quem utilizou o papel e a caneta acabou escrevendo menos palavras e quase metade de escritas literais, quando comparado a quem fez os registros na ferramenta eletrônica. Dessa maneira, ao passo que o teclado facilita o registro e permite mais agilidade na escrita, as pessoas tomaram o processo como algo mais automático, dispendendo menos esforço mental e, possivelmente, abrindo brechas para distrações. Em contrapartida, a escrita com papel e caneta, por ser mais custosa, leva os sujeitos a pensarem e focarem na tarefa que estão fazendo, além de terem que ser mais seletivos, posto que não é 
possível escrever tão rápido quanto digitar, e só a tarefa de selecionar aquilo que deve ser registrado acaba sendo um trabalho mental que beneficia quem registra no papel. Por isso, na referida pesquisa, praticamente não houve diferença na avaliação de quem usou o papel e de quem usou o computador de maneira mais consciente e focada.

À vista disso, ao contrário do que os alunos ouvidos nesta pesquisa afirmam, não é possível hierarquizar o papel e as telas para a aprendizagem quando se pressupõe a garantia de atenção e foco nas aulas. É preciso considerar também que as tecnologias cada vez mais se aproximam e tentam atender às necessidades das pessoas. Logo, tendo em vista que muitos consideram a diferença entre o digitar e o escrever, criou-se as canetas para tablets, as quais podem ser usadas para desenhar, escrever, anotar e marcar em cima de documentos, diminuindo a distância do digitar, quando comparado à escrita, e permitindo uma experiência mais próxima do papel e da caneta em um suporte digital.

Ainda que essa tecnologia se aproxime do movimento da escrita, é relevante assinalar que há diferenças significativas nos usos do papel e da tela. Chartier (1999) aponta para uma mudança estrutural na maneira de ler um livro manuscrito ou impresso e ler um livro na tela, visto que a tela impõe um modo de organização muito diverso do papel.

Existe propriamente um objeto que é a tela sobre a qual o texto eletrônico é lido, mas este objeto não é mais manuseado diretamente, imediatamente, pelo leitor. A inscrição do texto na tela cria uma distribuição, uma organização, uma estruturação do texto que não é de modo algum a mesma com a qual se defrontava o leitor do livro de rolo da Antiguidade ou o leitor medieval, moderno e contemporâneo do livro manuscrito ou impresso, onde o texto é organizado a partir de sua estrutura em cadernos, folhas e páginas. O fluxo sequêncial do texto na tela, a continuidade que lhe é dada, o fato de que suas fronteiras não são mais tão radicalmente visíveis, como no livro que encerra, no interior de sua encadernação ou de sua capa, o texto que ele carrega, a possibilidade para o leitor de embaralhar, de entrecruzar, de reunir textos que são inscritos na mesma memória eletrônica: todos esses traços indicam que a revolução do livro eletrônico é uma revolução de estruturas do suporte material do escrito assim como nas maneiras de ler." (p. 12-13).

Sem dúvidas, pode-se usar essa mesma distinção e a mudança estrutural do suporte material para o escrever no papel e o digitar em computadores e tablets, ainda que se use as canetas com tecnologia touch screen. Escrever em um caderno também pressupõe uma série de regras e normas, dentre as quais, escritas da esquerda para a direita, de cima para baixo, seguindo uma ordem das páginas, entre as linhas, respeitando as margens. Enquanto, nas telas, a organização é sequenciada de cima para baixo, sem virar páginas, há a possibilidade de digitar, ir e voltar, acrescentar e suprimir, alterar margens, mudar a orientação da página, acrescentar diferentes tipos de recursos, letras e ícones. Além disso, apesar da aproximação do uso que se 
faz no papel, as canetas para tablets também oferecem recursos distintos das canetas convencionais.

Um aspecto importante de ser ressaltado é que todos os estudantes afirmaram, como se vê nos excertos abaixo, que a possibilidade de usar a caneta no tablet fez com que passassem a usar muito mais essa ferramenta:

Quadro 12 - Excertos das falas dos alunos sobre usar a caneta para o tablet faz com que utilizem mais a ferramenta

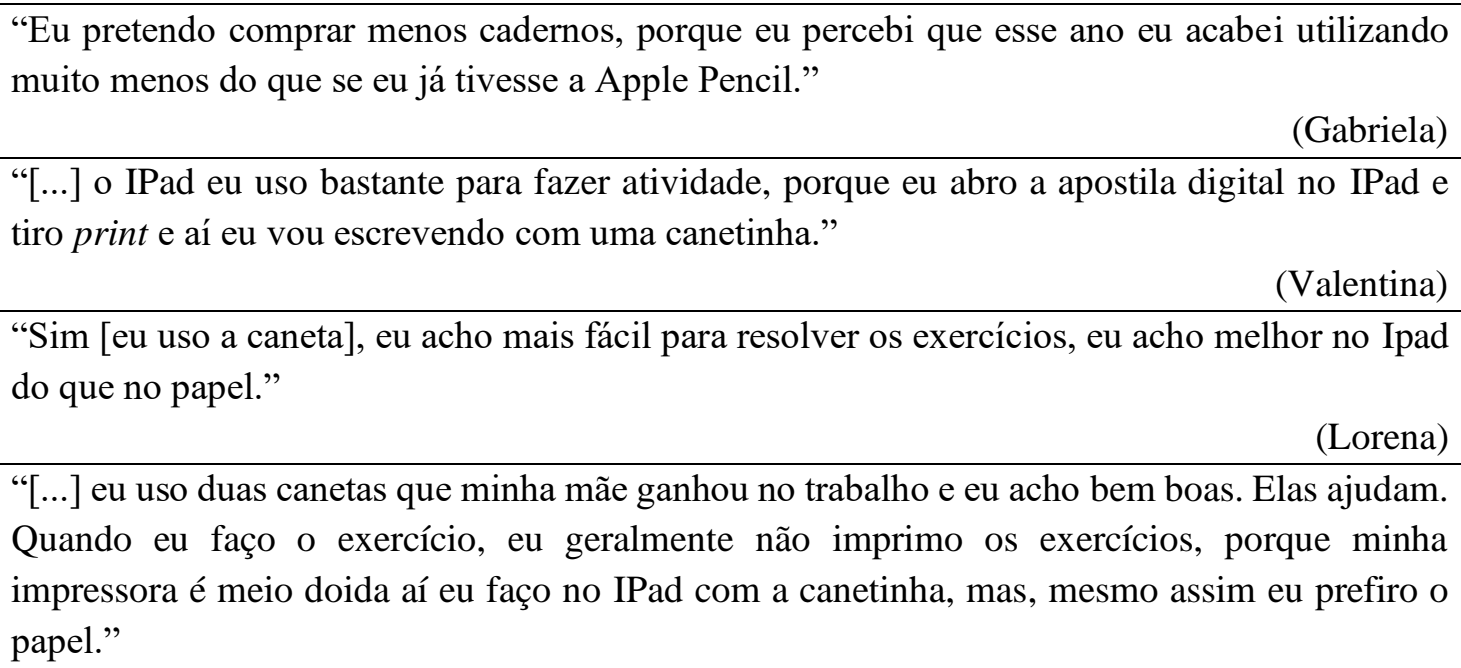
muito menos do que se eu já tivesse a Apple Pencil."

(Gabriela)

"[...] o IPad eu uso bastante para fazer atividade, porque eu abro a apostila digital no IPad e tiro print e aí eu vou escrevendo com uma canetinha."

(Valentina)

"Sim [eu uso a caneta], eu acho mais fácil para resolver os exercícios, eu acho melhor no Ipad do que no papel."

(Lorena)

"[...] eu uso duas canetas que minha mãe ganhou no trabalho e eu acho bem boas. Elas ajudam. Quando eu faço o exercício, eu geralmente não imprimo os exercícios, porque minha impressora é meio doida aí eu faço no IPad com a canetinha, mas, mesmo assim eu prefiro o papel."

Fonte: Elaborado pela Autora (2021).

(Roberta)

Gabriela mostra que usar a caneta no tablet fez com que ela diminuísse o uso dos seus cadernos físicos, considerando comprar menos desses itens no ano seguinte. Já Valentina, Lorena e Roberta, as três alunas que preferem utilizar caderno de papel, também ressaltam que usar a caneta tornou a resolução de exercícios mais prática, uma vez que não precisa mais imprimir, resolver, fotografar e enviar para os professores, basta apenas editar o próprio documento com a caneta. Ou seja, verifica-se que o uso das canetas foi um fator determinante no uso dos suportes de escrita digitais.

Chartier (1999) também menciona que a pessoa que lê por meio de telas pode se sentir de certo modo mais livre do que aquele que o faz por meio do papel, devendo isso à existência de uma distância maior e menos corporal entre o texto e o leitor. Nas suas palavras:

De um lado, o leitor da tela assemelha-se ao leitor da Antiguidade: o texto que ele lê corre diante de seus olhos; é claro, ele não flui tal como o texto de um livro em rolo, que era preciso desdobrar horizontalmente, já que agora ele corre verticalmente. De um lado, ele é como o leitor medieval ou o leitor do livro impresso, que pode utilizar referências como a paginação, o índice, o recorte do texto. Ele é simultaneamente esses dois leitores. Ao mesmo tempo, 
é mais livre. O texto eletrônico lhe permite maior distância com relação ao escrito. Nesse sentido, a tela aparece como ponto de chegada do movimento que separou o texto do corpo. O leitor do livro em forma de códex coloca-o diante de si sobre uma mesa, vira suas páginas ou então segura quando o formato é menor e cabe nas mãos. O texto eletrônico torna possível uma relação muito mais distanciada, não corporal. (CHARTIER, 1999, p. 13-16).

Novamente, pode-se estender tal perspectiva para quem escreve, posto que também há o afastamento entre o autor e o texto nas telas, havendo uma maior corporeidade entre o autor e o papel:

Aquele que escreve na era da pena, de pato ou não, produz uma grafia diretamente ligada a seus gestos corporais. Com o computador, a mediação do teclado, que já existia com a máquina de escrever, mas que se amplia, instaura um afastamento entre o autor e seu texto. A nova posição de leitura, entendida num sentido intelectual, é radicalmente original: ela junta, e de um modo que ainda deveria estudar, técnicas, posturas, possibilidades que, na longa história da transmissão do escrito, permaneciam separadas. (CHARTIER, 1999, p. 16).

Nesse trecho, o referido autor também aponta para a junção da edição e da distribuição nos textos eletrônicos, já que, no contexto digital, isso, é algo único de fato, sendo que o produtor do texto é também o seu editor, formatando-o e difundindo-o. Deseja-se, então, refletir acerca das aprendizagens possibilitadas pelo uso das tecnologias digitais nas escolas. Sobre o assunto, Coll e Monereo (2010, p. 33) fazem uma importante colocação:

O impacto das TIC sobre o aparecimento dessas necessidades educacionais e a importância de novas competências que precisamos adquirir e desenvolver no marco da Sociedade da Informação é um tema complexo, uma vez que, por um lado ambos os fatores estão na origem das novas necessidades educacionais e de formação, mas por outro parecem destinados a desempenhar um papel decisivo na satisfação dessas mesmas necessidades.

Desse modo, considera-se importante a discussão sobre o aprender na era digital, evidenciando o que e como o uso dessas tecnologias impactam nessas aprendizagens. Entendese que a educação escolar deve ter como objetivo dar sentido ao mundo que rodeia os alunos, de modo que os ensinem a interagir com ele e a resolver os problemas que lhe são apresentados (COLL; MONEREO, 2010), o que parece conferir um papel fundamental à presença das TDIC nas escolas. No entanto, a questão incide sobre a extensão e o sentido dessas tecnologias na escola. Isso porque não se tem os mesmos efeitos quando: elas são consideradas fontes de informação; são instrumentos para interação; seu uso está relacionado a passatempos, sem muita relação com as propostas escolares; ou se pensa nessas ferramentas completamente integradas aos afazeres de alunos e professores, como é o caso da escola analisada.

Lalueza, Crespo e Camps (2010) fazem uma análise das mudanças nas habilidades trabalhadas com os alunos quando se deixa de trabalhar com lápis e papel e se passa a usar um editor de textos. Amplia-se essa análise e considera-se que o uso das canetas touch screen se 
aproximam dessas habilidades mobilizadas pelas ferramentas digitais. Antes de mais nada, os autores destacam, como já foi mencionado nesta pesquisa, a otimização do tempo (visto que que o uso de editor de textos permite fazer mais coisas em menos tempo), ou ainda fazê-las de forma melhor - uma vez que é possível refazer um parágrafo ou mudá-lo de lugar, reorganizar ou reagrupar frases que estavam em partes diversas do texto, apagar ideias que não fazem mais sentido, acrescentar novas partes ou citações. Viabilizar isso, por si só, como assinalam os autores, já demonstra como as TIC ampliam as habilidades. Todas essas possibilidades foram destacadas pelos alunos entrevistados que fazem uso do tablet como suporte de escrita, argumentando a praticidade e a maior facilidade na organização com o uso desse instrumento.

Em segundo lugar, os autores se debruçam a evidenciar as habilidades que são adquiridas ao utilizar o editor de textos ou em quais aspectos melhora-se as capacidades mesmo em tarefas nas quais não se usa tal ferramenta. Eles mostram que usar de maneira frequente o editor de textos para revisar as escritas pode tornar os sujeitos mais eficazes em pensar formas alternativas de se expressar, de melhorar a redação ou readequar frases e partes do texto, causando, assim, um efeito nas capacidades de quem usa para além dos limites do próprio instrumento. De acordo com os pesquisadores, "usar uma determinada ferramenta não só permite que melhoremos nossas habilidades quando a utilizamos como deixa um 'rastro', ou seja, uma vez que nos apropriamos de seu uso, nossas capacidades melhoram” (LALUEZA, CRESPO, CAMPS, 2010, p. 50).

Ademais, no que se refere à análise de como o uso da ferramenta de edição de textos altera a forma de compor o texto, encarando o que se quer produzir, de modo a organizar a informação até a edição final, o trabalho mostra que isso também acontece de maneira bem diversa do uso do lápis, da caneta e do papel. Isso porque, de acordo com os pesquisadores, a ferramenta transformou a maneira de compreender a tarefa de escrita, gerando, inclusive, novas metas, provocando, assim, um efeito com o uso da tecnologia.

Em relação aos efeitos produzidos, esses autores apontam, baseados nas ideias de Salomon e Perkins (2005), que há três tipos que incidem sobre a inteligência humana: com a tecnologia, da tecnologia e por meio da tecnologia (LALUEZA, CRESPO, CAMPS, 2010). Levando em consideração a produção de textos em ferramentas digitais, tem-se que

uma tecnologia aparece em um contexto histórico como amplificadora das habilidades humanas (efeitos "com"). No caso das ferramentas que amplificam capacidades cognitivas, como a escrita, ocorre também um efeito de melhora dessas capacidades (efeito "de"). Finalmente, mediante o uso da nova tecnologia, a longo prazo há uma reorganização do próprio sistema cognitivo, de maneira pela qual se pensa nessa cultura. É esta última modalidade, os efeitos "por meio" da tecnologia, a que mais nos interessa a 
partir de uma perspectiva evolutiva. (LALUEZA, CRESPO, CAMPS, 2010, p. 50-51).

Isso não se constitui, no entanto, em uma defesa ferrenha do uso dos suportes digitais nas escolas. Mas deseja-se salientar suas potencialidades, que podem ou não vir a ser efetivadas dependendo do uso que se faz delas. Conforme afirmam os autores do estudo citado, alterar as ferramentas culturais, no caso, os cadernos analógicos para cadernos digitais, supõe também mudar formas de inteligência valorizadas na sociedade e, por conseguinte, no desenvolvimento cognitivo, emocional e social dos sujeitos. Portanto, quando se leva em conta a implicação das tecnologias digitais no desenvolvimento humano, é fundamental ter consciência de quais habilidades são potencializadas com essas ferramentas, como o uso reverbera nessas capacidades dos indivíduos, logo, como transformam a atividade, de maneira que demandem novas necessidades para o seu desenvolvimento.

Ao analisar as habilidades e capacidades mobilizadas pelas tecnologias digitais, remetese a uma nova reflexão: o quanto os alunos se posicionam diante dessas ferramentas como consumidores ou como produtores. As TDIC são marcadas pela potencialidade de, segundo Costa et al. (2013), a colaboração, a interatividade, a mobilidade, a interconectividade, a velocidade, a globalização, o compartilhamento e a velocidade - atributos da sociedade contemporânea em rede -, as quais são alterações significativas implicadas pelas tecnologias digitais na sociedade e, especialmente, no que se refere a maneiras de aprender e apreender.

Essa ideia vai ao encontro de Coll e Monereo (2010, p. 29), quando afirmam que a entrada das tecnologias digitais fortalece o trabalho pautado na cooperação, ampliando assim as competências mobilizadas na tarefa:

A incorporação das TIC aos diferentes âmbitos da atividade humana, e especialmente às atividades laborais e formativas, vem contribuindo de maneira importante para reforçar essa tendência de projetar metodologias de trabalho e de ensino baseadas na cooperação. Assim, por exemplo, trabalhar em rede com apoio das TIC representa uma nova maneira de se entender e de estabelecer as competências necessárias para cumprir as tarefas e realizar as atividades estabelecidas. (p. 29).

Tal potencialidade altera a lógica de trabalho individual e, por vezes, até mesmo competitiva encontrado nas escolas, na medida em que organiza o espaço para a distância entre os alunos, na hierarquia dos cargos e da configuração do ambiente, na dificuldade e mesmo na oposição ao trabalho cooperativo, na classificação dos alunos para as avaliações, entre outras práticas e ações. Ainda, abre-se para a perspectiva de se ter realmente uma escola cooperativa, com alunos que saibam colaborar uns com os outros em seus processos de aprendizagem.

Durante as observações das aulas presenciais verificou-se uma diversidade na organização dos estudantes. Isso porque, embora a maior parte das salas estivesse organizada 
de modo que a lousa fique na frente, também verificou-se que as carteiras estão dispostas em duplas. Havia um apelo grande pelas avaliações e provas e para que a escola seja reconhecida publicamente pelos seus êxitos em aprovações nos vestibulares nacionais e internacionais. Durante as aulas, eram previstos diversos momentos de troca e discussão coletiva, além de tempos de trabalho individual. Há, ainda, aulas que são realizadas em salas que privilegiam o trabalho coletivo na resolução de problemas, sem carteiras e lousa.

À parte o exposto, uma das questões feitas aos alunos foi justamente a respeito da potencialidade da cooperação, questionando se eles compartilhavam suas anotações e cadernos ou se faziam de modo colaborativo, sem ter um "dono", mas que fosse algo mais coletivo, tanto no que se refere aos cadernos analógicos quanto aos digitais. Apesar de não negarem tirar as dúvidas de colegas, quando estes os procuram, apenas dois deles responderam afirmativamente, demonstrando o quanto esses objetos são marcados pela autoria e pela pessoalidade, no sentido da posse. Destaca-se os seguintes trechos das falas dos estudantes:

Quadro 13 - Excertos das falas dos alunos sobre compartilhar seus cadernos com seus colegas \begin{tabular}{|l}
$\begin{array}{l}\text { "No meu caso fica só pra mim mesmo [o caderno], mas eu estou no grupo [de WhatsApp] da } \\
\text { sala. Eu não sou o mais sociável, mas de qualquer forma, quando eles têm alguma dúvida e } \\
\text { perguntam... Então não é uma questão de distribuir as anotações, mas a questão de entender a } \\
\text { matéria e perguntar para os outros." }\end{array}$ \\
(Tomás, grifo nosso) \\
\hline $\begin{array}{l}\text { "Não, mas se alguma pessoa tem alguma dúvida a gente vai lá e responde. Se alguém fala } \\
\text { 'Me ajuda em tal coisa?', a gente vai lá e se ajuda." } \\
\text { (Lorena, grifo nosso) }\end{array}$ \\
$\begin{array}{l}\text { "Olha, por enquanto eu não compartilho o caderno com outras pessoas, mas eu tenho uma } \\
\text { irmã que é mais nova do que eu e ela fica com os meus cadernos antigos, que eu usei para } \\
\text { estudar. Eu acho que seria mais fácil, mas a gente só vai descobrir isso quando ela tiver no } 7^{\circ}\end{array}$ \\
$\begin{array}{l}\text { quiser alterar alguma coisa. Então eu acho que no futuro ela vai aproveitar bastante os cadernos } \\
\text { já digitalizados." }\end{array}$
\end{tabular} (Gabriela, grifo nosso)

"Ah, depende... Tem matérias que eu mando alguns resumos para as minhas amigas, como tem outras que eu não mando os resumos."

(Julia, grifo nosso)

"Às vezes eu até resumo com os meus amigos, porque a gente acha legal esse negócio de trabalho em grupo. A gente se dá bem, sabe? Às vezes eles falam: "Vocês querem tal resumo? Eu fiz, vocês querem foto?" e aí eu falo “Ah, eu fiz também, vocês querem?" Algumas vezes nós fizemos juntos, porque na pandemia tá difícil, né?"

(Roberta, grifo nosso)

Fonte: Elaborado pela Autora (2021). 
Assim, vê-se que a Gabriela conjectura que possivelmente a irmã possa se beneficiar de suas anotações, pensando em um compartilhamento dos seus cadernos no plano familiar. Já a Julia assevera que depende, compartilhando alguns resumos dos registros feitos e outros, não. Apenas a Roberta indica a prática dos registros coletivos ou colaborativos. Acredita-se que outros alunos possam concordar com essa última aluna no que diz respeito a gostar dos trabalhos em grupos e colaborativos. No entanto, tem-se a hipótese de que esse formato não é valorizado e nem explicitado pelos professores, de maneira que ainda não passou a fazer parte da cultura e do hábito desses alunos. É como se, de alguma forma, ao compartilhar ou ao fazer de maneira colaborativa, estivessem transgredindo uma regra escolar ou dos professores.

Desse modo, consideram-se as habilidades e competências suscitadas pela entrada das tecnologias digitais na escola e, com isso, a ideia de que os alunos têm a oportunidade de assumir uma postura não só de consumidores, como também de produtores. Parte-se do pressuposto as mídias digitais alteraram a maneira linear e hierárquica da comunicação, facultando ao receptor a oportunidade de interagir com a mensagem, alterá-la e até produzi-la. Logo, amplia-se o olhar para os cadernos, especialmente os digitais, concebendo-os para além de um receptáculo de conteúdos, mas com a possibilidade de inserção de fotos, vídeos, áudios, anotações pessoais, imagens da lousa ou da internet, cópias, hiperlinks, e mais, com chance de não ser somente algo individual, mas realizado de maneira coletiva e compartilhada, possibilitando-lhe portanto, ser fruto de algo que foi produzido.

O economista Alvin Toffler (1990), há mais de quarenta anos, cunhou o termo prossumidor (ou prosumer), agrupando as palavras producer e consumer (em português, produtor e consumidor, respectivamente). Entretanto, o conceito não ficou circunscrito à economia e, com a consolidação da Web 2.0, passou a também ser empregado nas discussões acerca da comunicação. Agora, é também ampliado para a educação. Desse modo, como está exposto no trabalho colaborativo de Costa et al., (2013, p. 55) acerca dos prosumers,

nesse novo panorama, no que diz respeito a um universo colaborativo, podemos ressaltar o aparecimento de indivíduos que podem construir em determinadas possibilidades, sua própria aprendizagem, com o uso de novas lógicas, semânticas e literacias da sociedade em rede.

Isso se deve ao fato de que as tecnologias digitais de informação e comunicação abrem possibilidades nunca vistas no que se refere à possibilidade de buscar uma informação, acessála, processá-la, representá-la, transmiti-la e, por fim, compartilhá-la (COLL; MAURI; ONRUBIA, 2010). Estes autores assinalam que o potencial mediador das tecnologias digitais se torna efetivo quando são usadas por estudantes e docentes para planejar, regular e orientar as próprias atividades e aquelas que são alheias, introduzindo mudanças importantes nos 
processos intra e interpsicológicos envolvidos no ensino e na aprendizagem. Tais processos serão mais expressivos quanto maior for o uso das tecnologias digitais na organização da atividade de maneira conjunta em torno das aprendizagens.

É, portanto, principalmente nos usos que são mediados pelas relações entre os três elementos do triângulo interativo [aluno, professor conhecimento], seja condicionando e determinando as formas de organização da atividade conjunta, seja construindo um ambiente ou espaço de ensino e aprendizagem, a relação da qual cabe esperar, em nosso critério, que o potencial das TIC para transformar e inovar as práticas educacionais se expresse com especial intensidade. (COLL; MAURI; ONRUBIA, 2010, p. 86, grifo dos autores).

Para Meirieu (1998), uma aprendizagem só ocorre quando um sujeito toma uma informação e a transpõe para seu projeto pessoal. E mais, uma informação só é identificada pelo sujeito se já estiver, de algum modo, assimilada por um projeto de utilização, integrada da dinâmica do sujeito. Para o teórico, é justamente a "interação entre a identificação e a utilização que é gerador de significação, isto é, de compreensão.” (MEIRIEU, 1998, p. 54). Nesse sentido, somente existe uma situação de aprendizagem efetiva, quando o sujeito pode mobilizar esses dois elementos - identificação e utilização - de maneira ativa e com objetivo.

À vista disso, levando em conta esses conceitos, reforça-se a ideia de que ter um caderno completo com cópias do que os professores dizem em suas aulas presenciais ou por vídeos não garante que ali houve aprendizados. Ao contrário, quando os alunos fazem seus registros mais personalizados, anotando o que para eles faz sentido, seja o que consideram importante da aula toda ou apenas o que acham mais complexo, da maneira como preferem, por textos maiores ou menores, resumos, itens, palavras-chave, esquemas ou mapas mentais, presume-se que ali houve muito mais interação entre a identificação com o conteúdo, mobilizando sua utilização, tendo mais chances de culminar, assim, em compreensão e aprendizado.

Em uma palestra online oferecida pela USP (LEITURAS..., 2020), com o título Leituras da escola: do giz à internet, destinada a estudantes e educadores, Jorge Ramos do Ó afirma que a escrita do próprio sujeito se constitui em uma biblioteca de si próprio e, portanto, o caderno de um estudante é uma enciclopédia inédita da inteligência humana. É curioso que Tomás, um dos alunos entrevistados, faz uma fala exatamente definindo seus cadernos como sua enciclopédia particular:

O objetivo principal de eu fazer o caderno digital é eu conseguir acessar de qualquer lugar, rever o conteúdo de qualquer lugar, é como uma minienciclopédia. Então assim eu consigo rever os estudos, por exemplo, se eu quero rever uma matéria. Seria muito difícil achar a matéria que eu quero no caderno, mas no digital, pra mim, fica uma organização mais fácil, mais visual e você consegue ver os conteúdos de uma melhor forma. (Tomás, grifo nosso). 
Outra questão feitas durante a entrevista foi se os alunos reliam seus registros e em quais momentos. As respostas, com poucas exceções, giraram bastante em torno do estudo para as avaliações:

Quadro 14 - Excertos das falas dos alunos sobre a motivação em fazer registros nos cadernos \begin{tabular}{|l|}
\hline "É importante ficar revendo a matéria, porque é conhecimento, né?" \\
(Tomás) \\
\hline "[...] primeiro faço os registros da aula que o professor mandou no caderno físico e aí eu pego \\
o IPad e eu anoto as coisas que são relacionadas à aula para eu entender melhor a matéria e aí \\
depois, quando eu estou próxima à avaliação ou se eu estou fazendo alguma atividade e eu não \\
entendi, eu volto para esses resumos que eu fiz para mim mesma no IPad, e eu consulto para \\
entender melhor."
\end{tabular}

(Gabriela)

Sempre que eu vou escrever outra anotação no caderno eu leio basicamente tudo, porque como eu vou escrever uma nova coisa, tudo está conectado e se eu não entender uma coisa do começo do ano eu não vou entender essa que eu estou aprendendo agora. Aí eu revejo tudo do caderno, também, geralmente, não tem muita coisa no caderno, é mais exercício e aí eu não anoto, só faço o exercício. E o resumo eu sempre releio para as provinhas, testes, essas coisas mais notas assim.

"Às vezes, [eu releio] o que eu fiz para estudar para uma provinha e depois uma bimestral [...] às vezes, é bem raro, quando eu lembro que tem tal informação em tal lugar, aí eu vou ver. Sei lá, vai ter uma prova, eu quero lembrar de alguma coisa que não lembro de jeito nenhum, aí eu vou lá e dou uma olhadinha, mas isso acontece muito pouco. Mas, por exemplo, ontem enquanto eu estava estudando para a última prova, eu estava fazendo um resumo de um tópico de revisão e aí eu fui olhar os registros anteriores, porque já estava um pouco em cima da hora e aí eu fui olhar o que eu tinha feito para a outra prova e isso me facilitou bastante, mas eu não costumo, quando eu estou fazendo resumo da mesma matéria, não costumo recorrer ao anterior, sabe? Eu faço de novo, porque é uma maneira de estudar. Hoje em dia eu costumo fixar bastante enquanto faço resumo."

(Lorena)

"Para estudar para as provas também. Às vezes eu até anotava de novo. Outra coisa do porquê eu não uso muito o IPad para fazer anotação, principalmente para a prova, porque eu acho que digitando eu não fixo muito o conteúdo na minha cabeça. Então eu acho que quando eu anoto, fica bem mais claro, eu entendo mais também. Então eu prefiro e sempre preferi anotar no caderno mesmo."

(Valentina)

"Eu anoto durante as aulas do bimestre e aí quando chega mais perto das provas bimestrais eu releio. Pra estudar mesmo."

(Julia)

Fonte: Elaborado pela Autora (2021).

Ante o exposto, Tomás afirma que tem o costume de rever as matérias e considera essa uma prática importante, sendo que, em outro momento da conversa, diz, justamente, que faz o 
caderno digital além das anotações de aula no caderno analógico para poder acessá-lo de qualquer lugar, revendo os conteúdos. Gabriela também declara que revisita suas anotações quando surge alguma dúvida ou quando vai estudar para as provas. Roberta, a aluna que tem por hábito fazer resumos de todos os conteúdos, alega que toda vez que faz uma nova anotação, recupera as anteriores, porque uma é continuidade da outra, estão interligadas, e o resumo todo é relido para as avaliações. Lorena, por sua vez, diz que até acontece de revisitar uma anotação quando se está com alguma dúvida pontual, mas é raro. O comum é rever nos momentos de estudos para as avaliações. Valentina, de maneira mais direta, aponta que somente revista suas anotações para estudar para as provas e, por vezes, até faz novos registros como forma de estudo nesses momentos. De maneira parecida, Julia também afirma que relê suas anotações para estudar para as avaliações.

Percebe-se, então, que os cadernos são usados por esses alunos para guardar as informações e conteúdos da aula, os quais são transformados em anotações mais pessoais e personalizadas na escrita de resumos e estudos para as avaliações. Assim, a avaliação é como um pivô para o uso do caderno. Isto quer dizer que, as provas impulsionam os alunos a usarem os cadernos, visto que todos eles releem os cadernos para estudar para as avaliações. Tal questão implica em se analisar a importância e a função dos cadernos, analógicos e digitais, para os estudantes.

Como se pôde notar, por mais que tenham ocorrido mudanças significativas na educação, o caderno (digital ou analógico) continua sendo um material extremamente utilizado nas instituições escolares, com mais ou menos permanências a depender dos alunos, da disciplina e das práticas pedagógicas dos professores. Uma das questões de pano de fundo para esta investigação é se a importância dos cadernos analógicos tende a diminuir na medida em que outros suportes de escrita aparecem. A partir das entrevistas com os alunos verifica-se que, por um lado, essa é uma possibilidade, conquanto alguns estudantes afirmam que ou já começaram a usar menos os cadernos, como é o caso da Julia, ou intentam diminuir esse uso, como declara Gabriela: "Eu pretendo comprar menos cadernos, porque eu percebi que esse ano eu acabei utilizando muito menos do que se eu já tivesse a Apple Pencil. Então, como eu já tenho, eu acho que no ano que vem eu vou comprar menos cadernos para aproveitar mesmo.”.

Em contrapartida, há outras três estudantes que afirmam que não conseguiriam estudar sem seus cadernos de papel. Desse modo, quando questionados sobre a importância desse material no contexto escolar, dos seis alunos, três consideraram-no um material muito importante, justificando que esse artefato é o meio e o instrumento que lhes permite organizar os processos de aprendizagem. De acordo com as falas das próprias alunas: 
Quadro 15 - Excertos das falas dos alunos que demonstram que o caderno é um instrumento para aprender

\begin{tabular}{|lr|}
\hline $\begin{array}{l}\text { "Muito [importante]. Muito, porque tem gente que aprende melhor escutando ou falando } \\
\text { sozinho, mas eu sou uma pessoa que aprende melhor lendo e escrevendo, então eu acho que } \\
\text { pra mim se não tivesse caderno eu estaria bem ruim nas matérias." }\end{array}$ & (Roberta) \\
\hline $\begin{array}{l}\text { "Nossa!!! Sim!!! Sem o caderno eu não ia conseguir fazer um resumo, não ia conseguir estudar, } \\
\text { então..." }\end{array}$ & (Lorena) \\
\hline "Muito importante!!! Nossa! Não sei como eu estudaria sem o caderno!" & (Valentina) \\
\hline
\end{tabular}

Fonte: Elaborado pela Autora (2021).

Ao que parece, Roberta explica que aprende lendo e escrevendo, e o caderno é justamente o suporte que melhor se adequa às suas necessidades e estratégias para aprender. Lorena, por sua vez, esclarece que seu modo de aprender é fazendo resumos, e evidencia ser por meio dos cadernos que faz as suas anotações centrais de estudos. Já Valentina mostra que, para ela, esse material tem uma função essencial em seus estudos, não conseguindo sequer imaginar como poderia aprender e estudar sem ele.

Entretanto, para os outros três alunos, os cadernos analógicos não têm essa importância central, já que dois deles apontam para a preferência pelo suporte digital, e o outro, pelas apostilas digitais:

Quadro 16 - Excertos das falas dos alunos que demonstram que o caderno é um instrumento para aprender

(continua)

"Olha, eu sou suspeita para falar porque antes eu era um pouco "Nossa, mas escrever no IPad..." Mas hoje em dia, eu vejo que na minha opinião a gente não precisa tanto dos cadernos, porque os IPads acabam sendo mais práticos e, além de serem mais ecológicos, pensando no dinheiro, a gente acaba tendo que gastar menos, porque a gente não tem que ficar comprando material, cadernos. Eu uso um pouco de cada um, mas cada vez mais eu uso menos o caderno. Se eu fosse comparar o meu caderno no $1^{\circ}$ bimestre, quando eu ainda não tinha a Apple Pencil, ele está superlotado, mas agora desses bimestres, eles estão mais vazios, porque eu estou passando as coisas para o IPad, porque pra mim é mais fácil. Então eu acho que com o tempo, eu estou deixando de usar um pouco os cadernos e passando para os IPads."

(Gabriela, grifo nosso)

"O caderno físico ocupa peso na mala. Ele não é mais necessário, porque tem que carregar o estojo, o caderno, os livros, as folhas, a pasta. No IPad é tudo um só."

(Julia, grifo nosso) 
(conclusão)

"Sobre o caderno, eu prefiro mais a apostila, porque a apostila tem o conteúdo, então você não precisa ficar copiando. Eu acho que copiar leva um tempo muito grande, mas, por outro lado, você pratica sua escrita e seu vocabulário copiando e escrevendo com as suas palavras."

(Tomás, grifo nosso)

Fonte: Elaborado pela Autora (2021).

De outro modo, a mesma questão foi feita no que se refere aos tablets. Dessa vez, dos seis alunos, todos reconheceram esse material como importante em seu contexto escolar, uma vez que é por meio deles que se tem acesso ao material didático (as apostilas digitais), assistese às aulas no contexto remoto, realizam-se as atividades solicitadas, acessa-se o Moodle e armazenam-se seus registros, atividades e documentos.

Quadro 17 - Excertos das falas dos alunos sobre a importância dos tablets

\begin{tabular}{|lr|}
\hline "Sim [é importante]! Eu só uso ele." & (Julia) \\
\hline $\begin{array}{l}\text { "[...] Então eu acho que com o tempo, eu estou deixando de usar um pouco os cadernos e } \\
\text { passando para os IPads." }\end{array}$ & (Gabriela) \\
\hline & "Ah... são [importantes], porque a gente pode ver os materiais por eles e pesquisar e fazer várias \\
coisas. Mas eu acho que eu ainda prefiro usar os cadernos do que os tablets." & (Lorena) \\
\hline $\begin{array}{l}\text { "[...] é muito importante, porque a gente tem as apostilas digitais, tem o Moodle, que a gente } \\
\text { assiste as aulas, mas até para as aulas presenciais também era bem importante, porque tinham } \\
\text { vários aplicativos que a gente tinha que usar, então ele é muito importante também." }\end{array}$ \\
$\begin{array}{l}\text { "O IPad é importante, né? Quem consegue ter um IPad ou tablet consegue armazenar os dados } \\
\text { de uma forma muito mais organizada e sem o risco de perder. Por exemplo, o livro digital que } \\
\text { a gente tem, a gente consegue acessar, fazer as atividades e que você não consegue fazer num } \\
\text { livro físico. Por exemplo, em matérias de línguas, espanhol e inglês, você consegue ouvir o } \\
\text { material, ouvir os diálogos e praticar. Então eu acho bom ter os dois [caderno e tablet]. Mas se } \\
\text { possível, somente o IPad, né? Porque tem uma maior capacidade de organização e } \\
\text { armazenamento." }\end{array}$ \\
$\begin{array}{l}\text { "[...] o tablet acho muito importante porque é mais fácil para pesquisar as coisas e é isso } \\
\text { mesmo." }\end{array}$ \\
\hline
\end{tabular}

Fonte: Elaborado pela Autora (2021).

Portanto, percebe-se que os tablets são mencionados como importantes por todos eles, mas os motivos que justificam essa importância são divergentes, sendo que alguns não os correlacionam com se constituir em suportes de escrita digitais. Para Julia, o tablet é fundamental, porque ela só utiliza esse suporte para seus registros. Do mesmo modo, Gabriela 
associa a importância desse material com suas anotações. Lorena, por sua vez, considera esse um material relevante, embora prefira os cadernos analógicos, e ressalta a vantagem de se conseguir fazer pesquisas por meio dele. Já Valentina relaciona a importância dos tablets com o acesso às apostilas digitais e o Moodle, fundamentais no momento do ensino remoto, mas também reconhece que, no contexto presencial, é um material importante para acessar todos os aplicativos indicados pela escola. Tomás tem uma visão similar, complementando a vantagem de ter as apostilas digitais nesse material, uma vez é possível acessar recursos diversos, como áudios, e chamando a atenção para o benefício de armazenar tudo em um único aparelho, com segurança e de maneira organizada.

No que se refere à função atribuída a esses materiais, são diversas e variam para cada um deles, conforme se verifica em suas falas:

Quadro 18 - Excertos das falas dos alunos que tratam sobre a função de cadernos e tablets "Principalmente para eu poder entender as coisas, então pra mim, se eu não faço as coisas
escrevendo, tanto no IPad ou no próprio caderno físico, eu não entendo direito o conteúdo. Eu
sou uma pessoa bem que precisa escrever e ver para entender e aprender. Então pra mim eu
gosto muito de escrever à mão, porque quando eu digito eu sinto que eu fixo pior a matéria, e
quando eu escrevo à mão com cor, com desenho e essas coisas eu acho que eu lembro melhor.
Então eu acho que é basicamente essa importância pra mim dos cadernos e IPads.".
(Gabriela)
"Para facilitar o estudo do aluno. [...] mas de maneiras diferentes. O caderno me ajuda a
memorizar, eu gosto de escrever, a aprender realmente, mais a matéria do professor. O IPad
me ajuda a aprofundar o assunto, porque eu consigo pesquisar, ver a apostila digital, essas
coisas."

(Roberta)

"O caderno eu uso mais para fazer anotação e o IPad eu uso mais para fazer as atividades e agora também para guardar as anotações."

(Tomás)

"O caderno eu uso para fazer meus registros e o IPad eu uso bastante para fazer atividade, porque eu abro a apostila digital no IPad e tiro print e aí eu vou escrevendo com uma canetinha."

(Valentina)

"Ah, os cadernos para estudar mesmo. Os tablets eu uso para estudar quando precisa e também para me divertir, ver série, filme."

(Lorena)

"Para facilitar, para não ter que levar tanto material, para deixar tudo mais organizado, mais colorido, com imagens e melhor para estudar."

(Julia)

Fonte: Elaborado pela Autora (2021). 
De maneira geral, as funções de cadernos e tablets aparecem misturadas nas falas dos estudantes. Para duas alunas, Gabriela e Roberta, ambos têm a mesma função de maneiras distintas, sendo que, para a primeira aluna, está relacionada à possibilidade de escrever e, para a segunda, serve para facilitar o estudo. Já Tomás, Valentina e Roberta atribuem funções diferentes aos materiais. Os alunos Tomás e Valentina usam os cadernos para registrar as aulas e utilizam o tablet para fazer as atividades de folhas soltas, mas Tomás também armazena suas anotações no equipamento, enquanto Valentina atribuiu um uso diverso, servindo para tirar fotos da tela das aulas ou das apresentações de Power Point e inserir anotações pessoais a partir delas. Lorena atribui funções de naturezas distintas, afirmando que os cadernos estão relacionados à escola e aos estudos, enquanto o tablet está associado a atividades de lazer, como para assistir filmes e séries, podendo também ser usado para estudar, quando necessário. Julia, por sua vez, por não usar mais cadernos físicos, sequer menciona sua função, evidenciando que os tablets têm como papel facilitar e ajudar na organização dos estudos.

Portanto, diante dessas respostas não é possível afirmar que os cadernos têm seus dias contados. Se, por um lado, observa-se uma tendência à adesão dos suportes digitais, principalmente depois de os alunos passarem a usar as canetas próprias para os tablets, de maneira que podem escrever no aparelho digital e não mais digitar, de outro lado, têm-se alunos que o consideram um material essencial, sem conseguir imaginar o caderno fora da lista de materiais escolares. Além disso, com exceção da Julia, os outros cinco estudantes enxergam utilidade nos usos dos cadernos analógicos, indicando que, ao menos por ora, esses materiais tendem a continuar sendo usados pelos alunos, mesmo quando estes têm acesso a suportes digitais.

Apesar de fazer coro ao grupo que prefere o caderno de papel, Roberta, em sua entrevista, assinala acreditar que, futuramente, os cadernos digitais substituirão os cadernos analógicos, uma vez que as tecnologias avançam rapidamente:

[...] eu acho que mais pra frente provavelmente não vai ter muito caderno. Infelizmente. E é bom a gente já ir se adaptando com a tecnologia nova [...]. Minha irmã de cinco anos está fazendo coisas que eu aprendi com dez anos. Eu acho que está avançando muito rápido, provavelmente não vai ter mais caderno. Só vai ser caderno digital. (Roberta).

Ela chama a atenção para o fato de que a irmã mais nova faz coisas que ela fazia com o dobro da idade. Ou seja, ainda que ela tenha 12 anos e, portanto, seja nativa digital, percebe que a irmã, sete anos mais nova, interage e mexe em aplicativos muito antes do que ela. Tal constatação a faz perceber como a relação das pessoas com as TDIC se altera rapidamente, o 
que a leva crer que possivelmente suportes de escrita digitais vão acabar substituindo os cadernos de papel.

Outro elemento que aparece na fala de duas alunas e que é importante de ser evidenciado diz respeito à questão do hábito ou ao costume de usar os cadernos analógicos:

Eu acho que é uma coisa de hábito mesmo, sabe? Eu me acostumei a fazer desse jeito. Nas aulas $[. . .]^{32}$ ela usa um aplicativo bem legal e tudo. Eu até baixei ele, mas só usei para testar, eu queria explorar, só que eu prefiro fazer no caderno mesmo por uma questão de hábito. (Lorena, grifos nossos).

Então ano passado eu tentei fazer [os registros] no IPad, mas não deu certo, porque eu não sabia onde estava, eu não achava, não dava certo. A agenda eu também tenho que ter a física, porque no IPad eles até ensinaram como usar o calendário, mas eu não consigo muito, porque eu já estava acostumada. Como na minha escola antiga a gente nem podia levar aparelhos eletrônicos, só tinha caderno físico para tudo, eu acho que eu já me acostumei assim. (Valentina, grifo nosso).

Essas duas alunas expressam que preferem os cadernos analógicos porque estão habituadas e/ou acostumadas a usar o papel para fazerem suas anotações e para estudarem, evocando suas experiências anteriores de registro, destacando que, desde os primeiros anos de escolarização, utilizam cadernos de papel. Retoma-se, então, a dimensão do projeto político pedagógico explicitada no octógono, visto que ainda há uma espécie de estranhamento por parte de alguns alunos com as tecnologias digitais tão presentes na escola. Como se pôde perceber pelas falas das estudantes e pela própria dificuldade em encontrar uma escola de Ensino Fundamental I que fizesse uso expressivo dos recursos digitais, salienta-se a importância de incorporar essas tecnologias nos processos educativos e nas práticas pedagógicas. Conforme Almeida (2018, p. 12) aponta, isso significa integrá-las ao currículo da escola,

[...] que requer expandir sua concepção para além de listas de temas de estudos previstos e identificar o currículo real desenvolvido na prática pedagógica, o que é constituído por conhecimentos, metodologias, tecnologias, linguagens, recursos, relações sociais e pedagógicas criadas no ato educativo.

É evidente que toda essa coleta de dados se refere a um contexto (dimensão também considerada no octógono) privilegiado do nosso país, já que, como se verificou nos dados do TIC Educa, ter um tablet de uso individual dos alunos não é, nem de longe, a realidade da maior parte da educação brasileira. Contudo, salienta-se que essa é uma importante discussão, que se torna imprescindível no contexto do ensino remoto e que, até então, não tinha sido encarada com a devida importância, mesmo em instituições com contextos favorecidos.

\footnotetext{
${ }^{32}$ Por questões éticas, o nome da professora foi suprimido.
} 
Na esteira disso, Moran (2018, p. 11) anuncia que as escolas que não incorporam o digital são instituições incompletas, pois não consideram a conectividade entre as pessoas, aspecto fundamental das relações do século em que vivemos:

Escolas deficientes em integrar o digital no currículo são escolas incompletas, pois escamoteiam uma das dimensões básicas na qual os humanos vivem no século XXI, ou seja, conectados, em rede, navegando competentemente entre mundos antes separados, hoje híbridos, em que a sinergia de processos não distingue fronteiras físico-digitais "realidade" presencial-digital-virtual.

Toda essa integração vai além do currículo e das concepções trazidas dos projetos políticos pedagógicos das instituições e esbarram nos professores. $\mathrm{Na}$ instituição pesquisada, pôde-se verificar que, em certa medida, os docentes reconhecem a potência das tecnologias digitais e autorizam o uso. Contudo, é preciso salientar que, da mesma forma que os alunos precisam ser ensinados a utilizar as TDIC, para os professores isso também é necessário, visto que é preciso conhecer os recursos digitais, desenvolver habilidades para utilizá-los, ter propriedade para fazer escolhas pedagógicas potentes.

Tem-se, no entanto, uma lacuna na formação de professores em relação às tecnologias digitais. Um exemplo disso está na Faculdade de Educação da Universidade de São Paulo, maior universidade da América Latina, onde não há nenhuma disciplina no curso de graduação em Pedagogia que trata das TDIC. Este trabalho compreende as tecnologias como um recurso e, ao mesmo tempo, uma linguagem. Por isso, em tese, não precisaria haver uma disciplina de formação. Como estamos vivendo um período de transição, em que há um descompasso entre os usos dos alunos e dos professores, ter uma disciplina sobre isso nas faculdades se faz necessário ao menos por ora, a fim de que se conheça os recursos, aprenda a usá-los, saiba de suas potencialidades e limitações, até que se passe a incorporá-los nas suas práticas pedagógicas de maneira consciente e refletida.

Consequentemente, o professor também precisa se colocar na posição dos alunos para poder compreender suas escolhas e preferências, uma vez que acaba por compartilhar com eles o processo que viveu na posição também de aluno. Desse modo, o docente só pode compartilhar com seus alunos as potencialidades e os usos das tecnologias digitais se ele próprio os reconhecer e utilizar. A esse conceito de aproximar a formação vivida pelos docentes à forma como ele trabalhará com seus alunos dá-se o nome de Homologia dos processos, termo cunhado por Donald Schön.

Segundo Moran (2018, p. 16) destaca, o contexto pede uma mudança de postura dos professores, de modo que se assuma, cada vez mais, uma postura mediadora, auxiliando a construção de conhecimento dos alunos. Eis o que diz o autor: 
A reflexão pede uma mudança de postura, em que gradativamente o educador se posicione como um mediador, um parceiro na construção de conhecimentos que não está no centro do processo. Quem está no centro, nessa concepção, são o aluno e as relações que ele estabelece com o educador, com os pares e, principalmente, com o objeto do conhecimento. [...] No mundo atual, marcado pela aceleração e pela transitoriedade das informações, o centro das atenções passa a ser o sujeito que aprende, a despeito da diversidade e da multiplicidade dos elementos envolvidos nesse processo. (p. 16);

Vale ressaltar, ainda, que há um discurso por parte de algumas pessoas sobre um temor de que os professores sejam substituídos pelas máquinas. E há vários motivos para que isso não aconteça. Coll e Monereo (2010) argumentam que as habilidades fundamentais para mexerem nas tecnologias digitais, como falar, escrever e ler, são ensinadas pelos docentes. Igualmente, são eles quem garantem às novas gerações condições de significatividade e confiabilidade. Ademais, tudo o que está na internet precisa ser filtrado, selecionado, ordenado, contextualizado, para que possa ser assimilado e transformado em conhecimento. E toda essa curadoria também é feita pelos professores. Além disso, como já foi mencionado, embora as tecnologias facilitem a interação, a colaboração, a troca, elas "não resolvem os problemas de fundo: as dificuldades de entender-nos, de aceitar os outros como são, de compreender o mundo interior próprio e dos outros.”, como Moran (2012, p. 59) afirma. Sem dúvidas, o professor humano tem um papel fundamental nesse apoio de constituição e compreensão de si e do outro.

Portanto, as tecnologias digitais de informação e comunicação trazem diversos desafios e problemas que devem ser considerados pelos doclentes e pela instituição, de modo a fazer parte do "projeto pedagógico de aprendizagem ativa e libertadora" (MORAN, 2018, p. 11). Apesar disso, não se pode invalidar, recusar ou ignorar as tecnologias digitais na educação em um mundo hiper conectado como o nosso se constitui hoje. Também, Almeida (2018) alerta para a imprescindibilidade de construir uma educação que ofereça condições de aprendizagem em contextos de incertezas - a pandemia escancarou fortemente uma dessas situações - que privilegie o trabalho em grupo, o compartilhamento de tarefas, a convivência com a diversidade, a participação ativa, a autonomia para resolução de problemas e o desenvolvimento de diversos letramentos.

Dessa forma, de acordo com a referida pesquisadora, faz-se necessário analisar tanto as contribuições, as potencialidades e as mudanças acarretadas pela incorporação das tecnologias digitais e dos diversos recursos com múltiplas linguagens midiáticas quanto a interação com a cultura do digital, de modo que se (re)pense (n)a educação com o objetivo de criar contextos autênticos de aprendizagem mediados também pelas tecnologias (ALMEIDA, 2018). 


\section{CONSIDERAÇÕES FINAIS}

Nesta dissertação, a pesquisa investigou se, quando estão inseridas nas escolas, as tecnologias digitais apenas substituem o uso dos cadernos de papel ou se acrescentam potencialidades e novas possibilidades a esse suporte de escrita, ou ainda, se são utilizadas concomitantemente aos cadernos analógicos. No contexto do ensino remoto e online imposto pelas medidas de distanciamento social e pelo fechamento das escolas em virtude da pandemia COVID-19, este fim se torna ainda mais latente, uma vez que passou-se a questionar em que momentos dessa escola com aulas virtuais, na qual o tablet já fazia parte da lista de material dos alunos, é utilizado o caderno de papel.

A pesquisa não pretendeu, de forma alguma, defender ou tentar comprovar os benefícios da substituição dos cadernos por outros instrumentos ou aparelhos mais modernos. Ela se constituiu em uma investigação sobre esses suportes com a crença de que há espaço para os dois e que uma tecnologia não anula a outra. Desse modo, acredita-se que não é porque se escreve nos tablets ou em notebooks e celulares, que se vai deixar de escrever nos cadernos, usando papel e caneta. Da mesma forma, não é porque se lê em computadores, que se deixará de ler livros; escutar música em aplicativos ou em rádios não faz com que as pessoas deixem de ir a shows. Tampouco defende-se que aconteça a inserção a todo custo das tecnologias digitais ou que as escolas sejam equipadas sem que haja uma reflexão educativa e pedagógica sobre o que isso implica. É fundamental, portanto, que se pense em como usar essas tecnologias superando uma dicotomia.

Durante o período em que se acompanhou as aulas e nas entrevistas com os alunos, conforme discutido no decorrer da dissertação, constatou-se que, se tem-se uma aluna (Julia) que afirma já não usar cadernos analógicos, existem também outros dois estudantes (Gabriela e Tomás) que alegam utilizar esse material, mas preferirem fazer seus registros em tablets. Há, inclusive, outras três (Lorena, Valentina e Roberta), as quais asseguraram que, não obstante usem seus aparelhos digitais em outras tarefas e atividades, para fazer suas anotações de estudos ainda preferem fazê-las no caderno físico, seja porque estão habituadas, acostumadas ou porque sentem que aprendem mais e melhor.

Considera-se, no entanto, que, embora se verifique o uso dos cadernos analógicos, evidenciando traços de permanências no uso desse suporte, percebe-se também mudanças ao longo de sua constituição como um material que faz parte da cultura escolar. Ainda assim, é preciso assinalar que nem mesmo as permanências são idênticas ao longo desse tempo, já que os contextos se alteraram inúmeras vezes. Ressalta-se, portanto, a dinâmica escolar: o uso 
permanece, mas em outro contexto, com outros conteúdos, outros suportes, outros valores, de modo a permitir indicar que a forma escolar (VINCENT; LAHIRE; THIN, 2001) não é a mesma. Ou seja, há alterações no tempo, no espaço e nas relações entre docentes e estudantes, conquanto algumas delas não sejam tão expressivas.

Verificou-se também que o uso dos suportes de escrita, tanto analógicos quanto digitais, estão estreitamente ligados aos estudos, especialmente, na preparação para as avaliações e provas. Os alunos foram unânimes em declarar que retomam seus registros e anotações para estudar para as provas, mostrando que as motivações para o uso ainda estão relacionadas à capacidade de guarda e conservação da escrita escolar. Ao considerar que as videoaulas estão gravadas e disponibilizadas para os alunos, nesse contexto de ensino remoto, vê-se um traço de permanência dos modos da escola antes da pandemia que impactam nesse novo momento: mesmo que se tenha outras ferramentas para conservar os conteúdos, os alunos permanecem fazendo seus registros, seja no papel ou no tablet. Tal constatação está relacionada a uma ideia muito mencionada pelos estudantes, a escrita a serviço do aprender.

Ainda no que se concerne às avaliações, o contexto da pandemia conduz para uma outra reflexão sobre o que e como deve ser avaliado. Nesse período, as provas foram uma temática bastante polêmica, uma vez que precisaram acontecer também de maneira remota e, com isso, muitos professores tinham dificuldade em identificar se as atividades tinham sido realizadas realmente por seus alunos, se os estudantes as fizeram sem consulta e se houve troca de informações entre eles. Nesse sentido, diferente do que acontecia até então nas aulas presenciais, ter um caderno, seja analógico ou digital, com registros das aulas virtuais e das videoaulas pode auxiliar no momento da prova porque oferece a possibilidade de servir de apoio às reflexões. Assim, se os cadernos são compreendidos como instrumentos de registros pessoais das aprendizagens, questiona-se os motivos pelos quais eles não podem ser consultados em uma avaliação. Se se prevê avaliações baseadas em memorização, de fato, a consulta aos registros não faz sentido porque, nesse caso, se restringiria a uma cópia das anotações. No entanto, se pretende-se uma avaliação mais alinhada ao momento da sociedade e do atual paradigma da educação do século XXI que se vive hoje, com acesso a tantas informações tão rapidamente, em que o conhecimento é compartilhado, os cadernos podem estar presentes nesse momento, visto que são justamente um dispositivo que potencializa a organização e a conexão das aprendizagens, ao mesmo tempo em que pode validar aquilo que o sujeito está refletindo.

Ademais, apesar da função relacionada ao armazenamento dos registros, a fim estudar para as avaliações, percebeu-se que, nos dois tipos de suporte, os alunos fazem suas anotações em formatos muito diversos: em tópicos, texto, resumos, palavras-chave, esquemas, mapas 
mentais, mostrando a autonomia do modo de escrita em detrimento de cópias. Esse aspecto foi salientado pelos estudantes como uma diferença notada com as aulas virtuais, apontando que, antes estavam acostumados a copiar certos conteúdos da lousa; com as videoaulas, não sentem mais essa necessidade.

Portanto, percebe-se que uma potencialidade desse novo formato foi descentralizar da figura dos professores a autoridade e as orientações daquilo que deve ser registrado, anotado, copiado, que, em tese, é um conteúdo mais importante. Sem a figura do professor presente diante de seus alunos, essas prescrições, que normalmente estavam em suas falas, desaparecem das videoaulas. O que acaba impactando nos registros dos alunos que passam a fazer suas anotações de maneira mais autônoma e pessoal, como se mencionou, e traz um aprendizado importante, na medida em que possibilita utilizar a escrita como reflexo daquilo que se pensa e que sente, em relação a si próprio, ao conteúdo, ao professor, superando a ideia de escrita como técnica.

Um dos legados da pandemia é que não há a necessidade de ficarmos integralmente todos no mesmo lugar para aprender ao mesmo tempo e com as mesmas pessoas. Verificou-se a possibilidade de aprendizagens personalizadas, flexíveis, ubíquas e integradas (MORAN, 2012). Além disso, possibilitou avanços na individuação do ensino, que foi, por tantas vezes, almejada.

Todavia, um dos cuidados que se tem que ter ao inserir as tecnologias digitais nas escolas é com relação à formação dos estudantes no sentido da responsabilidade. Todos os atores da educação ficam muito mais expostos nesse no contexto digital, na pandemia ou fora dela. Assim, os alunos precisam compreender a seriedade de expor um professor, as aulas, a escola e seus colegas. Além de aprender a construir estratégias de se manter focado e implicado em seu processo de aprendizagem, mesmo tendo na ponta de seus dedos uma infinidade de recursos e de possibilidades de distrações.

Embora a escolha do suporte de escrita não tenha se mostrado determinante para o formato do registro, a partir das conversas com os alunos, constatou-se que, de fato, os suportes digitais oferecem possibilidades e facilidades exploradas pelos alunos, como inserção de ilustrações, fotos, vídeos, a função copia e cola, que não são exequíveis nos cadernos analógicos. Além disso, eles trazem outros benefícios que também não são possíveis com os cadernos: menos peso, menos gasto com papel (apesar do gasto com o equipamento e com energia), desnecessidade de um grande estojo e de mobiliário adequado para utilizá-los, acesso de qualquer lugar, possibilidade de apagar com mais facilidade e deslocar partes do texto, mais praticidade e organização, capacidade de armazenamento e otimização do tempo. 
À parte o exposto, o compartilhamento é uma potencialidade das tecnologias digitais bastante difundida nos estudos e pesquisas do referencial teórico e que não foi identificada com ênfase. Não é uma prática dos alunos compartilharem seus cadernos com seus colegas ou fazêlos de maneira coletiva ou colaborativa. Ainda se nota o forte traço de autoria e do caderno tomado como um objeto pessoal, embora se perceba que os cadernos digitais estejam se constituindo como espaços de produção de conteúdo, justamente em função de suas potencialidades.

No que se refere à importância, com exceção da aluna que não utiliza mais cadernos de papel, todos os outros disseram que esse material permanece sendo relevante para si, ainda que alguns dos alunos prefiram usar o tablet. Ao passo que em relação aos tablets, todos reconheceram esse material como importante no seu contexto escolar, visto que, segundo eles, é por meio desse aparelho que eles assistem as aulas online, realizam as atividades solicitadas, acessam o ambiente virtual de aprendizagem, têm acesso ao material didático e armazenam os arquivos de atividades e documentos.

Outrossim, considera-se relevante assinalar que os problemas que a pandemia trouxe para a educação, de maneira geral, não são novos, mas já estavam presentes em todos os níveis em certo sentido, do ponto de vista pedagógico. Ainda assim, esse contexto evidencia uma realidade nova, que revela e acelera a história e a necessidade das mudanças. Nesse sentido, Nóvoa $^{33}$ (VIVENCIANDO..., 2020) chama atenção para uma nova pedagogia, a Pedagogia do Encontro, privilegiando a instituição escolar como esse espaço privilegiado do encontro que deve ser enriquecido, complexificado e levado muito a sério. Encontros entre professores e estudantes, alunos com outros alunos, professores e conhecimento, estudantes e conhecimento, encontros com a ciência, a arte e com tudo o que está fora da escola. Amplia-se, então, essa ideia, para pensar que os suportes de escrita escolares também podem se constituir nesse espaço do encontro, concebendo os cadernos escolares como mais do que ferramentas: como pontes.

Tendo essa ideia em vista e pensando sobre os reflexos que a educação remota deixará, acredita-se que, para que o encontro tenha lugar, precisa-se de um novo ambiente escolar, que não se refere apenas ao espaço, mas à organização dos tempos, dos saberes, dos processos de trabalho de alunos e professores e, claro, também dos espaços. Segundo Nóvoa

\footnotetext{
${ }^{33}$ Antonio Nóvoa, professor da Universidade de Lisboa, faz uma conferência com o título Formação e prática docente no Ensino Superior: novos desafios do ensinar e aprender no evento Vivenciando 2020, que ocorreu online. Tal evento se constituiu em um ciclo de três seminários remotos (webinars) organizados pela Pró-reitoria de Pós-graduação da USP (PRPG USP) com a temática $O$ Ensino Superior no mundo pós-pandêmico e desafios do ensinar e aprender: contradições não-presenciais?. Foram realizados entre os meses de agosto e setembro daquele ano. De acordo com o site da PRPG USP, a abordagem dos temas tratados nos seminários envolve a complementação da formação docente e a capacitação do pós-graduando.
} 
(VIVENCIANDO..., 2020), como já foi apontado, há quatro dimensões que potencializam esse lugar de encontro: a cooperação, no sentido da possibilidade do trabalho conjunto; a convergência no que diz respeito aos saberes, ou seja, religar os saberes, reorganizando-os; a criação no sentido da ligação com a investigação e a criação científica; e a cidade, isto é, o contexto, relacionar-se para além dos muros da escola. Assim, se as tecnologias digitais apoiam essas quatro dimensões que possibilitam o encontro, que elas possam ser inseridas, com menos preconceito e com mais potência. Igualmente, se, para os estudantes, os cadernos físicos são capazes de dar conta dessas dimensões, que eles possam continuar existindo e sendo usados.

Para além da dimensão social e relacional da escola, é sabido que hoje os estudantes chegam com outros repertórios acerca das tecnologias digitais nas escolas, ao mesmo tempo em que professores utilizam essas ferramentas, por vezes com maior intensidade no âmbito pessoal. Logo, outro grande desafio da educação está em articular os repertórios de alunos e professores, a fim de contribuir com o processo de aprendizagem, cumprindo com esse outro papel central da escola.

Como se viu, de tempos em tempos, surgem novas demandas de tecnologias a serem inseridas dentro das instituições escolares; a do momento se refere às digitais. Em todos os casos, deve-se questionar: esse recurso vai me auxiliar a melhorar a minha condição de explicar, ensinar e dar acesso àquilo que eu não consigo de outra forma? Nesses momentos, faz-se importante identificar qual(is) é(são) os problemas e verificar se o novo recurso pode auxiliar na resolução ou não, a fim de que não se torne mais uma parafernália. No caso do digital, a questão está para além de aderir ou não, mas a serviço de que está o digital? Para que? Por quê? Com que utilidade?

Hannah Arendt (2007) mencionou que uma crise somente se torna catastrófica se é respondida com ideias prontas, feitas e com preconceito. Mas, como Nóvoa (2015) já apontava, inspirado por Furter (1970), as reflexões sobre a educação contemporânea devem ir além do que já se conhece e alimentar-se de ideias que, para além de pensar sobre o futuro no presente, organiza o presente de modo que o permita atuar e reverberar no futuro. $\mathrm{Ou}$, como Edgar Morin (1981) preconizou, é preciso aclarar o que se quer, de maneira a conservar a educação que se deseja, ponderar o que efetivamente precisa ser mudado, criado ou inventado para que de fato a educação seja universal e libertadora.

Reflexões essas fundamentais no trabalho dos professores. Como tal, não basta saber dar boas aulas, ter boas ações do ponto de vista pedagógico. É necessário que a Pedagogia seja um objeto de reflexão dentro das escolas, e que se reflita sobre o que se sabe e como se faz. 
Como afirma Moran (2012), à medida em que as tecnologias ficam mais avançadas, mais se tem a exigência de pessoas humanas, competentes, evoluídas e éticas na educação.

O que se averiguou, portanto, é que, no caso da escola em que a pesquisa foi realizada, na qual as tecnologias digitais fazem parte das práticas pedagógicas, e levando em consideração o contexto do ensino remoto, os cadernos digitais não apenas substituem os cadernos analógicos, visto que os primeiros possuem outras funções e potencialidades (gráficas e de armazenamento). Do mesmo modo, os cadernos de papel também têm funções específicas, relacionadas ao modo de aprender, para alguns estudantes, e ambos coexistem. Uma marca que fica deste trabalho é o desejo de que os estudantes tenham cada vez menos prescrições sobre o que devem fazer em seus registros e anotações; ao contrário, que possam mais e mais aprenderem sobre como analisar, relacionar, comparar, investigar, confrontar, para que, assim os cadernos, de papel ou digitais, possam ser espaços para dar sentido àquilo que é aprendido.

Ao finalizar a escrita desta dissertação, identifica-se diversas questões que ficam por responder ou que foram suscitadas ao longo das análises. O desenvolvimento de uma pesquisa pressupõe escolhas, recortes. Consequentemente era inevitável que tal fato acontecesse. Alguns exemplos de questionamentos que ficam são: a perspectiva dos professores no uso dos cadernos digitais; a relação da formação docente com as tecnologias digitais; a articulação dos repertórios de professores e estudantes; o(s) modo(s) como o uso das tecnologias pelos alunos fora da escola pode fortalecer e potencializar o uso dentro da instituição escolar; impactos e contribuições dos usos extraescolares das ferramentas digitais para as atividades dos alunos; as repercussões do uso dessas tecnologias durante o ensino remoto imposto pela pandemia do Coronavírus para a educação pós pandemia; os impactos no processo de aprendizagem de alunos e professores que não estavam habituados às tecnologias digitais e que se viram em meio a aulas online. Assim, comemora-se a possibilidade de ter descortinado algumas respostas e anseia-se por poder continuar buscando outras respostas para as inúmeras questões e reflexões possíveis. 


\section{REFERÊNCIAS}

ALMEIDA, Maria Elizabeth Bianconcini de. Apresentação. In: BACICH, Lilian; MORAN, José Manuel. Metodologias ativas para uma educação inovadora: uma abordagem teóricoprática. Porto Alegre: Penso, 2018. p. 9-13.

ALMEIDA, Maria Elizabeth Bianconcini de; VALENTE, José Armando. Integração currículo e tecnologias e a produção de narrativas digitais. Currículo Sem Fronteiras, [s. l.], v. 12, n. 3, p. 57-82, Set./Dez. 2012. Disponível em:

http://www.curriculosemfronteiras.org/vol12iss3articles/almeida-valente.pdf. Acesso em: 25 mar. 2020.

ALTENFELDER, Anna Helena et al. Fundamentos para a prática pedagógica na cultura digital. São Paulo: CENPEC, 2011. (Ensinar e aprender no mundo digital, v. 1).

ARENDT, Hannah. Entre o passado e o futuro. Tradução: Mauro W. Barbosa. São Paulo: Perspectiva, 2007.

BARRA, Valdeniza Maria Lopes da. Da pedra ao pó: o itinerário da lousa na escola pública paulista do século XIX. Goiânia: Gráfica UFG, 2016.

BARRERA, Tathyana Gouvêa da Silva. O movimento brasileiro de renovação educacional no início do século XXI. Orientadora: Lúcia Emília Nuevo Barreto Bruno. 2016. 274 p. Tese (Doutorado em Educação) - Faculdade de Educação, Universidade de São Paulo, São Paulo, 2016.

BELARMINO, Natália Machado. Os cadernos escolares que "falam": artefato de subjetivação de gênero e sexualidade. Orientadora: Rosângela Tenório de Carvalho. 2015. 181 f. Dissertação (Mestrado em Educação) - Centro de Educação, Universidade Federal de Pernambuco, Recife, 2015.

BRANDÃO, Maria Aparecida de Oliveira. Educação e cultura visual: apropriações da publicidade e das logomarcas no caderno escolar e o imaginário estudantil. Orientadora: Leda Tenório da Motta. 2010. 127 f. Dissertação (Mestrado em Comunicação e Semiótica) Pontifícia Universidade Católica de São Paulo, São Paulo, 2010.

BRASIL. Ministério da Educação. Base Nacional Comum Curricular. Brasília, DF: MEC, 2018.

BRASIL. Ministério da Educação. Secretaria de Educação Básica. Secretaria de Educação Continuada, Alfabetização, Diversidade e Inclusão. Secretaria de Educação Profissional e Tecnológica. Conselho Nacional da Educação. Câmara Nacional de Educação Básica. Diretrizes Curriculares Nacionais para a Educação Básica. Brasília, DF: Ministério da Educação: Secretaria de Educação Básica: Diretoria de Currículos e Educação Integral, 2013.

BRASIL. Lei no 11.724, de 6 de fevereiro de 2006. Altera a redação dos arts. 29, 30, 32 e 87 da Lei $n^{\circ}$ 9.394, de 20 de dezembro de 1996, que estabelece as diretrizes e bases da educação nacional, dispondo sobre a duração de 9 (nove) anos para o ensino fundamental, com matrícula obrigatória a partir dos 6 (seis) anos de idade. Brasília, DF: Presidência da 
República, 2006. Disponível em: http://www.planalto.gov.br/ccivil_03/_ato20042006/2006/lei/111274.htm. Acesso em: 20 mar. 2020.

BURKE, Peter. O que é história cultural? Tradução: Sérgio Goes de Paula. Rio de Janeiro: Jorge Zahar Editor, 2005.

CENTRO REGIONAL DE ESTUDOS PARA O DESENVOLVIMENTO DA SOCIEDADE DA INFORMAÇÃO. TIC Educação. São Paulo, [20--]. Disponível em: https://cetic.br/pt/pesquisa/educacao/. Acesso em: 22 maio 2021.

CHARTIER, Anne-Marie. Exercícios escritos e cadernos de alunos: reflexões sobre práticas de longa duração. In: CHARTIER, Anne-Marie (org.). Práticas de leitura e escrita: história e atualidade. Belo Horizonte: Autêntica: CEALE, 2007. p. 21-66. (Coleção Linguagem e Educação).

CHARTIER, Anne Marie. Um dispositivo sem autor - cadernos e fichários na escola primária. Tradução: Marta Maria Chagas de Carvalho e Valdeniza Maria da Barra. Revista Brasileira de História da Educação, Maringá, n 3, p. 9-25, jan./jun. 2002.

CHARTIER, Roger. A aventura do livro: do leitor ao navegador. Tradução de Reginaldo Carmello Correa de Moraes. São Paulo: UNESP, 1999.

CHARTIER, Roger. A história cultural entre práticas e representações. Tradução: Maria Manuela Galhardo. Lisboa: Difusão Editora, 1988.

CHERVEL, André. História das disciplinas escolares: reflexões sobre um campo de pesquisa. Teoria e Educação, n. 2, Porto Alegre, 1990, p. 177-229.

COLÉGIO BANDEIRANTES. Quem somos. São Paulo, [20--]. Disponível em: https://colband.net.br/quem-somos. Acesso em: 25 mar. 2020.

COLL, Cesar; MAURI, Teresa; ONRUBIA, Javier. A incorporação das tecnologias da informação e da comunicação na educação. In: COLL, Cesar; MONEREO, Carles. Psicologia da educação virtual: aprender e ensinar com as tecnologias da informação e da comunicação. Tradução: Naila Freitas. Porto Alegre: Artmed, 2010. p. 63-93.

COLL, Cesar; MONEREO, Carles. Educação e aprendizagem no século XXI: Novas ferramentas, novos cenários, novas finalidades. In: COLL, Cesar; MONEREO, Carles.

Psicologia da educação virtual: aprender e ensinar com as tecnologias da informação e da comunicação. Tradução: Naila Freitas. Porto Alegre: Artmed, 2010. p. 15-46.

COMITÊ GESTOR DA INTERNET NO BRASIL. Pesquisa sobre o uso das tecnologias de informação e comunicação nas escolas brasileiras: TIC educação 2019. E-book. São Paulo: CGI.br, 2020. Disponível em:

https://www.cetic.br/media/docs/publicacoes/2/20201123090444/tic_edu_2019_livro_eletroni co.pdf. Acesso em: 02 mar. 2020.

COMITÊ GESTOR DA INTERNET NO BRASIL. Pesquisa sobre o uso das tecnologias de informação e comunicação nas escolas brasileiras: TIC educação 2018. E-book. São Paulo: CGI.br, 2019. Disponível em: 
https://www.cetic.br/media/docs/publicacoes/216410120191105/tic_edu_2018_livro_eletroni co.pdf. Acesso em: 02 mar. 2020.

CORDEIRO, Jaime Francisco Parreira. Falas do novo, figuras de tradição: o novo e o tradicional na educação brasileira (anos 70 e 80). São Paulo: Editora da UNESP, 2002.

CORDOVA, Tania. Redações, Cartas e Composições Livres: o caderno escolar como objeto da cultura material da escola (Lages/SC - 1935). História da Educação, Porto Alegre, v. 20, n. 49, p. 209-226, maio/ago. 2016.

COSTA, Alan Q. et al. A emergência da concepção do prosumer na era da comunicação digital. Orientadora: Brasilina Passarelli. 2013. 100 p. Texto coletivo apresentado na disciplina "Novas Lógicas e Literacias Emergentes no Contexto da Educação em Rede: Práticas, Leituras e Reflexões" (Pós-graduação em Ciências da Comunicação) - Escola de Comunicações e Artes, Universidade de São Paulo, São Paulo, 2013.

ESCOLANO, Agustín. Arquitetura como programa. Espaço-escola e currículo. In: VIÑAO FRAGO, Antonio; ESCOLANO, Agustín. Currículo, espaço e subjetividade: a arquitetura como programa. Tradução: Alfredo Veiga-Neto. 2. ed. Rio de Janeiro: DP\&A, 1998. p. 19-57.

ESCOLANO BENITO, Agustín. Los professores en la história. In: MAGALHÃES, Justino; ESCOLANO, Agustín. Os professores na história. Porto: Sociedade Portuguesa de Ciências da Educação, 1999. p. 15-28.

FARIA, Vitoria Libia Barreto de. No caderno da criança, o retrato da escola. Orientadora: Léa Pinheiro Paixão. 1988. 258 p. Dissertação (Mestrado em Educação) - Faculdade de Educação, Universidade Federal de Minas Gerais, Belo Horizonte, 1988.

FERNANDES, Rogério. Um marco no território da criança: o caderno escolar. In: MIGNOT, Ana Chrystina Venancio (org.). Cadernos à vista: escola, memória e cultura escrita. Rio de Janeiro: EdUERJ, 2008. p. 49-68.

FERREIRO, Emilia. O ingresso na escrita e nas culturas do escrito: seleção de textos de pesquisa. Tradução: Rosana Malerba. São Paulo: Cortez, 2013.

FRAGO, Antonio Viñao. Por una historia de la cultura escolar: enfoques, cuestiones, fuentes. Culturas y civilizaciones. In: CONGRESO DE LA ASOCIACIÓN DE HISTORIA CONTEMPORÂNEA, III, 1998, Universidad de Valladolide. Anais [...]. Salamanca: Secretariado de Publicaciones e Intercambio Científico, 1998. p. 167-183.

FRAGO, Antonio Viñao. Culturas escolares, reformas e inovacciones: entre la tradicion e el cambio. JORNADAS ESTATALES DEL FÓRUM EUROPEO DE ADMINISTRADORES DE LA EDUCACIÓN, 8, 1996, Murcia. Anais [...]. Murcia: Compobell, 1996. p. 17-29.

FRAGO, Antonio Viñao. Historia de la educación e historia cultural: posibilidades, problemas, cuestiones. Revista Brasileira de Educação, São Paulo, n. 0, p. 63-82, set./dez. 1995.

FREIRE, Paulo. Pedagogia da autonomia: saberes necessários à prática educativa. São Paulo: Paz e Terra, 1996. (Coleção Leitura). 
FULLAN, Michael. O significado da mudança educacional. 4. Ed. Tradução: Ronaldo Cataldo Costa. Porto Alegre: Artmed, 2009.

FURTER, Pierre. Educação e reflexão. 3. ed. Petrópolis, RJ: Editora Vozes, 1970.

GALLEGO, Rita de Cassia. Relatório de pesquisa apresentado à CERT/USP. São Paulo: [s.n.], 2011.

GALLEGO, Rita de Cassia. Tecnologias educacionais, práticas pedagógicas e docência: entre tradições e imperativos de mudanças. In: PEREIRA, Aurea da Silva; DIAS, Ana Regina da Silva; Almeida, Risonete Lima de; Correia, Adilson da Silva (org.). Estágio e Prática Pedagógica: letramentos e tecnologias digitais em sala de aula. Curitiba: CRV, 2016. p. 169180.

GALLEGO, Rita de Cassia. A configuração temporal e as inovações nos modos de ensinar nas escolas públicas primárias (São Paulo-Brasil - 1850 a 1890). In: PERANDONES, Pablo Celada (ed.). Arte y oficio de enseñar. Dos siglos de perspectiva histórica. El Burgo de Osma, Espanha: Sociedad Española de Historia de la Educación: Universidad de Valladolid: Centro Internacional de la cultura escolar, 2011. p. 117-125.

GALLEGO, Rita de Cassia. Tempo, temporalidades e ritmos nas escolas primárias públicas em São Paulo: heranças e negociações (1846-1890). Orientadora: Denice Barbara Catani. 387 p. 2008. Tese (Doutorado em Educação) - Faculdade de Educação, Universidade de São Paulo, São Paulo, 2008.

GALlEGO, Rita de Cassia. Uso(s) do Tempo: a organização de atividades de alunos e professores nas escolas primárias paulistas (1890-1929). Orientadora: Denice Barbara Catani. 2003. 189 f. Dissertação (Mestrado em Educação) - Faculdade de Educação, Universidade de São Paulo, São Paulo, 2003.

GASPARI, Jaqueline Di. Mudanças de geração na era digital: o professor de matemática e seus alunos. Orientadora: Denise Silva Vilela. 2013. 122 f. Dissertação (Mestrado em Ciências Humanas) - Universidade Federal de São Carlos, São Carlos, 2013.

GHANEM JÚNIOR, Elie George Guimarães. Inovação em escolas públicas de nível básico: o caso Redes da Maré (Rio de Janeiro, RJ). Educação \& Sociedade, v. 34, n. 123, p. 425-440, abr./jun. 2013.

GHANEM JÚNIOR, Elie George Guimarães (coord.). Mudança educacional: inovação e reforma: relatório científico 2: final. v. 2. São Paulo: [S. n. ], 2006.

GVIRTZ, Silvina. Do currículo prescrito ao currículo ensinado: um olhar sobre os cadernos de classe. Tradução: Jaime A. Clasen. Bragança Paulista: Editora Universitária São Francisco, 2005.

GVIRTZ, Silvina; LARRONDO, Marina. Os cadernos de classe como fonte primária de pesquisa: alcances e limites teóricos e metodológicos para a sua abordagem. In: MIGNOT, Ana Chrystina Venancio (org.). Cadernos à vista: escola, memória e cultura escrita. Rio de Janeiro: EdUERJ, 2008. p. 35-48. 
GRENDEL, Marlene Terezinha. De como a didatização separa a aprendizagem histórica do seu objeto: um estudo a partir da análise de cadernos escolares. Orientadora: Maria Auxiliadora Schmidt. 2009. 248 f. Tese (Doutorado em Educação) - Universidade Federal do Paraná, Curitiba, 2009.

HÉBRARD, Jean. Por uma bibliografia material das escritas ordinárias: o espaço gráfico do caderno escolar (França - séculos XIX e XX). Tradução: Laura Hansen. Revista Brasileira de História da Educação, Campinas, v. 1, n. 1 [1], p. 115-141, jan./jun., 2001.

HOUAISS, Antônio; VILLAR, Mauro de Salles. Minidicionário Houaiss da Língua Portuguesa. Rio de Janeiro: Objetiva, 2008.

HUBERMAN, Alan Michael. Como se realizam as mudanças em educação: subsídios para o estudo do problema da inovação. Tradução: Jamir Martins. São Paulo: Cultrix, 1976.

INSTITUTO BRASILEIRO DE INFORMAÇÃO EM CIÊNCIA E TECNOLOGIA. BDTD. Sobre a BDTD. Brasília, DF, [20--]. Disponível em: http://bdtd.ibict.br/vufind/. Acesso em: 02 jan. 2019.

JACQUES, Alice Rigoni. As marcas de correção em cadernos escolares do curso primário do Colégio Farroupilha/RS 1948/1958. Orientadora: Maria Helena Câmara Bastos. 2011. 198 f. Dissertação (Mestrado em Educação) - Faculdade de Educação da Pontifícia Universidade Católica do Rio Grande do Sul, Porto Alegre, 2011.

JULIA, Dominique. A cultura escolar como objeto histórico. Tradução: Gizele de Souza. Revista Brasileira de História da Educação, Campinas, v. 1, n. 1 [1], p. 9-43, jan./jun., 2001.

KENSKI, Vani Moreira. Educação e tecnologias: o novo ritmo da informação. 8. ed. Campinas, SP: Papirus, 2012.

KENSKI, Vani Moreira. Aprendizagem mediada pela tecnologia. Revista Diálogo Educacional, Curitiba, v. 4, n. 10, p. 47-56, set./dez. 2003.

KÖHLE, Érika Christina. A aprendizagem da escrita no ensino fundamental II com o auxílio de suportes digitais. Orientadora: Stela Miller. 2016. 206 f. Dissertação (Mestrado em Educação) - Faculdade de Filosofia e Ciências, Universidade Estadual Paulista "Júlio de Mesquita Filho”, Marília, SP, 2016.

LALUEZA, José Luiz; CRESPO, Isabel; CAMPS, Silvia. As tecnologias da informação e da comunicação e os processos de desenvolvimento e socialização. In: COLL, Cesar;

MONEREO, Carles. Psicologia da educação virtual: aprender e ensinar com as tecnologias da informação e da comunicação. Tradução: Naila Freitas. Porto Alegre: Artmed, 2010. p. 4765 .

LEITURAS da escola: do giz à internet. Produção: Grupo de Estudos de Filosofia e História das ideias pedagógicas; Projeto Temático Saberes e Práticas em Fronteiras: por uma história transnacional da Educação. Convidados: Prof. Dr. Jorge Ramos do Ó; Prof. Dr. Julio Roberto Groppa Aquino. Mediadoras: Natália Campelo; Ticiana Fernandes. [S. l.: s. n.], 2020. 1 vídeo 
(95 min). Publicado pelo canal Marcelo Parra. Disponível em:

https://www.youtube.com/watch?v=VhEbt2PjWz8. Acesso em: 23 maio 2021.

LOPES, Isa Cristina da Rocha. Cadernos escolares: memória e discurso em marcas de correção. In: MIGNOT, Ana Chrystina Venancio (org.). Cadernos à vista: escola, memória e cultura escrita. Rio de Janeiro: EdUERJ, 2008. p. 187-203.

MERIEU, Philippe. Aprender... sim, mas como? Tradução: Vanise Dresch. 7. ed. Porto Alegre: Artes Médicas, 1998.

MIGNOT, Ana Chrystina Venancio (org.). Cadernos à vista: escola, memória e cultura escrita. Rio de Janeiro: EdUERJ, 2008a.

MIGNOT, Ana Chrystina Venancio. Um objeto quase invisível. In: MIGNOT, Ana Chrystina Venancio (org.). Cadernos à vista: escola, memória e cultura escrita. Rio de Janeiro: EdUERJ, 2008b. p. 7-13.

MIGNOT, Ana Chrystina Venancio. Antes da escrita: uma papelaria na produção e circulação de cadernos escolares. In: MIGNOT, Ana Chrystina Venancio (org.). Cadernos à vista: escola, memória e cultura escrita. Rio de Janeiro: EdUERJ, 2008c. p. 69-90.

MIGUEL, Marelenquelem. Entre atividades, cadernos e portifólios: análise dos saberes e materiais utilizados na educação infantil. Orientadora: Geovana Mendonça Lunardi Mendes. 2010. 179 p. Dissertação (Mestrado em Educação) - Centro de Ciências Humanas e da Educação, Universidade do Estado de Santa Catarina, Florianópolis, 2010.

MORAES, Sandrina Wandel Rei de. A leitura nos anos finais do ensino fundamental: um diálogo com os professores e as atividades de leitura registradas em cadernos escolares. Orientadora: Maria Amélia Dalvi Salgueiro. 2016. 260 f. Dissertação (Mestrado em Educação) Centro de Educação, Universidade Federal do Espírito Santo, Vitória, 2016.

MORAN, José Manuel. Metodologias ativas para uma aprendizagem mais profunda. In: BACICH, Lilian; MORAN, José Manuel (org.). Metodologias ativas para uma educação inovadora: uma abordagem teórico-prática. Porto Alegre: Penso, 2018. p. 1-25. (Desafios da Educação).

MORAN, José Manuel. A educação que desejamos: novos desafios e como chegar lá. 5. ed. Campinas, SP: Papirus, 2012. (Papirus educação).

MORAN, José Manuel. Educação inovadora na Sociedade da Informação. In: REUNIÃO ANUAL DA ANPED, 23, 2000, Caxambu, MG. Anais [...]. Caxambu, MG: ANPEd, 2000. p. $1-11$.

MORIN, Edgar. Pour sortir du XX Siècle. Paris: Nathan, 1981.

MUELLER, Pam A.; OPPENHEIMER, Daniel M. The Pen Is Mightier Than the Keyboard: Advantages of Longhand Over Laptop Note Taking. Psychological science, v. 25, n. 6, p. 1159-1168, abr. 2014. 
NEUBERT, Caroline Guião Coelho. Os sentidos atribuídos pelas crianças aos seus cadernos escolares. Orientadora: Luciane Maria Schlindwein. 2013. 155 p. Dissertação (Mestrado em Educação) - Centro de Ciências da Educação, Universidade Federal de Santa Catarina, Florianópolis, 2013.

NÓVOA, António. Educação 2021: para uma história do futuro. In: CATANI, Denice Barbara; GATTI JÚNIOR, Décio (org.). O que a escola faz? Elementos para a compreensão da vida escolar. Uberlândia: EDUFU, 2015. p. 51-69.

OLIVEIRA, Inês Barbosa de. Aprendendo com os cadernos escolares: sujeitos, subjetividades e práticas sociais cotidianas na escola. In: MIGNOT, Ana Chrystina Venancio (org.). Cadernos à vista: escola, memória e cultura escrita. Rio de Janeiro: EdUERJ, 2008. p. 129143.

PERRENOUD, Philippe. Não mexa na minha avaliação! Uma abordagem sistêmica da mudança. In: PERRENOUD, Philippe. Avaliação: da excelência à regularização das aprendizagens: entre duas lógicas. Porto Alegre: Artmed, 1999. p. 144-159.

PORVIR. Sobre nós. São Paulo, [20--]. Disponível em: https://porvir.org/sobre-nos/. Acesso em: 25 mar. 2020.

RAZZINI, Marcia de Paula Gregorio. Instrumentos de escrita na escola elementar: tecnologias e práticas. In: MIGNOT, Ana Chrystina Venancio (org.). Cadernos à vista: escola, memória e cultura escrita. Rio de Janeiro: EdUERJ, 2008. p. 91-113.

SALOMON, Gavriel; PERKINS, David. Do Technologies Make Us Smarter? Intellectual Amplification With, Of, and Through Technology. In: STERNBERG, R. J.; PREISS, D. D. (ed.). Intelligence and technology: The impact of tools on the nature and development of human abilities. New Jersey: Lawrence Erlbaum Associates Publishers, 2005. p. 71-86.

SANTANA, Josineide Siqueira de. Entre bordados, cadernos e orações: a educação de meninas e as práticas educativas no orfanato de São Cristóvão e na escola da Imaculada Conceição (1922-1969). Orientadora: Verônica dos Reis Mariano Souza. 2011. 149 f. Dissertação (Mestrado em Educação) - Universidade Federal de Sergipe, São Cristóvão, 2011.

SANTOS, Anabela Almeida Costa e. Aprendendo a usar cadernos: um caminho necessário para a inserção na cultura escolar. In: MIGNOT, Ana Chrystina Venancio (org.). Cadernos à vista: escola, memória e cultura escrita. Rio de Janeiro: EdUERJ, 2008a. p. 145-159.

SANTOS, Anabela Almeida Costa e. Cadernos e outros registros escolares da primeira etapa do ensino fundamental: um olhar da psicologia escolar crítica. Orientadora: Marilene Proença Rebello de Souza. 2008. 313 p. Tese (Doutorado em Psicologia) - Instituto de Psicologia, Universidade de São Paulo, São Paulo, 2008 b.

SANTOS, Anabela Almeida Costa e. Cadernos escolares na primeira série do ensino fundamental: funções e significados. Orientadora: Marilene Proença Rebello de Souza. 2002. 152 p. Dissertação (Mestrado em Psicologia) - Instituto de Psicologia, Universidade de São Paulo, São Paulo, 2002. 
SANTOS, Sônia de Oliveira. Apropriação da linguagem escrita por meio de aplicativos em dispositivos digitais. Orientador: Dagoberto Buim Arena. 2019. 331 p. Tese (Doutorado em Educação) - Faculdade de Filosofia e Ciências, Universidade Estadual Paulista "Júlio de Mesquita Filho", Marília, 2019.

SANTOS, Vera Mendes dos. Caderno Escolar: um dispositivo feito peça por peça para produção de saberes e subjetividades. In: CONGRESSO BRASILEIRO DE HISTÓRIA DA EDUCAÇÃO, 2., 2002a, Natal. Anais [...]. Natal: SBHE, 2002a. p. 1-10.

SANTOS, Vera Mendes dos. O nascimento dos cadernos escolares: um dispositivo de muitas faces. Orientador: Norberto Dallabrida. 2002. 134 f. Dissertação (Mestrado em Educação e Cultura) - Universidade do Estado de Santa Catarina, Florianópolis, 2002b.

SÃO PAULO. Prefeitura Municipal. Secretaria Municipal de Educação. Instrução Normativa SME n⿳3 30/2019, de 31 de outubro de 2019. Dispõe sobre a organização dos Laboratórios de Informática Educativa, e dá outras providências. São Paulo, SP: SME, 2019. Disponível em: http://legislacao.prefeitura.sp.gov.br/leis/instrucao-normativa-secretariamunicipal-de-educacao-sme-1-de-31-de-outubro-de-2019. Acesso em: 02 mar. 2020.

SÃO PAULO. Prefeitura Municipal. Secretaria Municipal de Educação. Currículo digital da cidade de São Paulo. Tecnologias para Aprendizagem. São Paulo, [2019?]. Disponível em: https://curriculo.sme.prefeitura.sp.gov.br/tecnologias-para-aprendizagem. Acesso em: 20 abr. 2020.

SÃO PAULO. Prefeitura Municipal. Secretaria Municipal de Educação. Instrução Normativa $S_{E} n^{\circ} \mathbf{2 6 / 2 0 1 8}$, de 11 de dezembro de 2018. Dispõe sobre a organização dos Projetos de Salas de Leitura, Espaços de Leitura, Núcleos de Leitura, de Laboratórios de Informática Educativa, bem como sobre a indicação de docentes para exercerem as funções de Professor Orientador de Sala de Leitura - POSL, Professor Orientador de Informática Educativa - POIE e dá outras providências. São Paulo, SP: SME, 2018. Disponível em: http://legislacao.prefeitura.sp.gov.br/leis/instrucao-normativa-secretaria-municipal-deeducacao-sme-26-de-11-de-dezembro-de-2018. Acesso em: 02 mar. 2020.

SÃO PAULO. Prefeitura Municipal. Secretaria Municipal de Educação. Portaria no 7.655/15, de 17 de dezembro de 2015. Dispõe sobre a organização das Salas de Leitura, Espaços de Leitura e Núcleos de Leitura na Rede Municipal de Ensino e dá outras providências. São Paulo, SP: SME, 2015. Disponível em:

http://legislacao.prefeitura.sp.gov.br/leis/portaria-secretaria-municipal-de-educacao-7655-de18-de-dezembro-de-2015. Acesso em: 02 mar. 2020.

SÃO PAULO. Prefeitura Municipal. Secretaria Municipal de Educação. Concepção e estrutura. São Paulo, [201-?]a. Disponível em:

http://portal.sme.prefeitura.sp.gov.br/Main/Page/PortalSMESP/Apresentacao-3. Acesso em: 02 mar. 2020.

SÃO PAULO. Prefeitura Municipal. Secretaria Municipal de Educação. Formação do POIE - Professor Orientador de Informática Educativa. São Paulo, [201-?]b. Disponível em: http://portal.sme.prefeitura.sp.gov.br/Main/Page/PortalSMESP/Formacao. Acesso em: 02 mar. 2020. 
SPOHR, Fúlvia da Silva. Cadernos, pincéis e netbooks: modulações tecnológicas em uma escola da rede pública de ensino básico. Orientadora: Maria Cristina Villanova Biazus. 2015. 244 f. Tese (Doutorado em Informática na Educação) - Centro Interdisciplinar de Novas Tecnologias na Educação, Universidade Federal do Rio Grande do Sul, Porto Alegre, 2015.

SOUZA, Flávia Mayer dos Santos; PIROLA, Maria Nazareth; REBOUÇAS, Moema Lucia Martins. A celebração do luxo nas capas de cadernos escolares. Revista Comunicação, Mídia e Consumo, São Paulo, v. 12, n. 33, p. 11-33, jan./abr. 2015.

SOUZA, Luani de Liz; TEIXEIRA, Lisley Canola Treis; CARMINATI, Celso João. Um computador por aluno: um dos ícones da modernização da escola brasileira na segunda década do século XXI. Educação em Revista, Belo Horizonte, v. 31, n. 3, p. 379-404, jul./set. 2015.

SOUZA, Rosa Fátima de. Lições da Escola Primária: um estudo obre a cultura escolar paulista ao longo do século XX. In: CONGRESSO BRASILEIRO DE HISTÓRIA DA EDUCAÇÃO, 3., 2004, Curitiba. Anais [...]. Curitiba: SBHE, 2004. p. 16-17. Tema: A Educação Escolar em Perspectiva Histórica.

SOUZA, Rosa Fátima de. Templos de civilização: a implantação da escola primária graduada no Estado de São Paulo: 1889-1910. São Paulo: UNESP, 1998.

TARDIF, Maurice. Saberes docentes e formação profissional. Petrópolis, RJ: Vozes, 2002.

TELEMBERG, Thalis. Tecnologia na educação: as representações de docentes de séries iniciais. Orientadora: Silvana Bernardes Rosa. 2004. 110 p. Dissertação (Mestrado em Engenharia de Produção) - Universidade Federal de Santa Catarina, Florianópolis, 2004.

TOFFLER, Alvin. Powershift: as mudanças do poder. Tradução: Luiz Carlos do Nascimento Silva. Rio de Janeiro: Record, 1990.

VIDAL, Diana Gonçalves. Culturas escolares: estudo sobre práticas de leitura e escrita na escola pública primária (Brasil e França, final do século XIX). Campinas, SP: Autores Associados, 2005.

VIÑAO, Antonio. Os cadernos escolares como fonte histórica: aspectos metodológicos e historiográficos. In: MIGNOT, Ana Chrystina Venancio (org.). Cadernos à vista: escola, memória e cultura escrita. Rio de Janeiro: EdUERJ, 2008. p. 49-68.

VINCENT, Guy; LAHIRE, Bernard; THIN, Daniel. Sobre a história e a teoria da forma escolar. Educação em Revista, Belo Horizonte, n. 33, p. 7-47, jun. 2001.

VINCENT, Guy. L'ecole primaire Française. Lyon: Presses Universitaires de Lyon; Paris: Editions de la Maison des Sciences de l'Homme, 1980.

VIVENCIANDO 2020: formação e prática docente no ensino superior: novos desafios do ensinar e aprender? Produção: Pró-Reitoria de Pós-Graduação da Universidade de São Paulo. Conferencista: António Nóvoa. Debatedor: Naomar de Almeida Filho. São Paulo: USP, 2020. 1 vídeo (82 min). Publicado pelo canal Pró-Reitoria de Pós-Graduação - USP. Disponível em: https://www.youtube.com/watch?v=_KFCyn6rLc. Acesso em: 23 maio 2021. 


\section{APÊNDICE A - ENTREVISTA COM TOMÁS}

Pesquisadora: Quais são os materiais que normalmente você utiliza para fazer seus registros da escola? Por quê?

Tomás: Dependendo da matéria, né? Mas eu uso basicamente meu estojo e um outro material físico, que pode ser um caderno, uma apostila ou outra coisa e meu IPad para fazer as anotações e atividades.

P: Por que tem essa diferença entre as matérias?

T: No começo do ano já tinha bolado tudo, a apostila e o material. Então dá pra aproveitar o material que tinha.

P: E o que mudou?

T: É, quando era uma atividade que não tinha muito material, eu podia fazer no caderno ou no IPad ou também em uma folha solta.

P: E onde você guarda essas folhas soltas?

T: Eu tenho uma pasta desde o começo do ano que eu guardo minhas atividades que necessita a impressão e essas folhas soltas.

P: E onde você prefere fazer os seus registros: no caderno ou no IPad?

T: É que assim, eu faço os registros no caderno para deixar tudo completo no caderno, mas se, por exemplo, tem um caderno digital, vamos dizer assim... eu também faço. Agora eu prefiro usar o digital, né? Eu acho mais fácil e fica mais organizado dessa forma digitalmente. Eu também consigo acessar o conteúdo de qualquer lugar.

P: Você me contou que usa o caderno e o caderno digital. Eles têm as mesmas coisas? Ou você anota coisas diferentes?

T: Então, eu faço o físico primeiro, né? Porque eu comecei o físico e aí eu vou preenchendo e aí eu passo o conteúdo do caderno físico para o digital de uma forma mais resumida.

P: Você mudou a maneira como faz seus registros se comparar antes e durante a pandemia?

T: Quando começou a pandemia, tinha mais atividade dos professores que não estavam na apostila e eu fazia mais no caderno antes, mas quando começou a pandemia, chegaram mais folhas soltas, então eu achei melhor fazer as atividades das folhas soltas no IPad, porque o próprio IPad tem algumas ferramentas para edição de arquivo e tal.

P: Você usa o Apple pencil?

T: Eu uso, eu uso o Apple pencil para pegar os arquivos e transformar eles. Eu uso o aplicativo Arquivos ele já é instalado no celular e no IPad. Essa parte de físico e digital pra mim não faz muita diferença no jeito que eu escrevo, mas uma diferença no depois que eu escrevo, porque 
quando eu escrevo no IPad fica tudo guardado e fica mais fácil do que fazer no físico, só que no digital nem sempre eu tenho acesso das coisas que eu faço. Mas não faz muita diferença. Se eu fosse escolher, eu escolheria o IPad.

P: Você acha que o resultado final do caderno digital é melhor?

T: É, fica mais organizado, essas coisas, tem mais controle, gasta menos papel. Porque tem essa coisa de gastar papel, porque, às vezes, eu imprimo errado e aí fica ruim. Quando eu erro no IPad é muito mais fácil de consertar, porque você consegue mudar de lugar, apagar uma palavra, deixar tudo junto.

P: Que outros recursos você acaba usando?

T: No Arquivos que é o aplicativo quem vem instalado, tem umas três variações de letras, variações de cor. Eu uso isso para diferenciar as minhas letras do enunciado ou às vezes eu escrevo mesmo com uma ferramenta que tem ou uso marca texto para destacar. Eu também comecei a usar o Mac, o computador da Apple, que também tem outros recursos. Eu uso isso aí para conseguir estudar.

P: E o que você costuma registrar?

T: Pra mim depende um pouco da matéria. Por exemplo: em História, meio que tinha um roteiro que a gente copiava e isso eu continuei. Mas em matérias como Geografia ou Matemática, tem algumas coisas que não estavam nas fichas de estudo ou que estava na videoaula e eu achava interessante, eu ia anotando no caderno e mais tarde eu passo pro IPad. Eu vi que os professores deixam mais livres agora.

P: Você gosta dessa maior liberdade com os seus registros?

T: Foi bem legal essa parte da liberdade, mas também deixa o tema mais variado. Então, por exemplo, vai ter uma prova, você copia automaticamente mais do que se pede. Então acho que você ganha mais conteúdo pra você, mas é ruim, de certa forma, porque você tem mais temas para estudar.

P: Você relê os registros que você faz tanto no caderno físico, quanto no caderno digital?

T: O objetivo principal de eu fazer o caderno digital é eu conseguir acessar de qualquer lugar, rever o conteúdo de qualquer lugar, é como uma minienciclopédia. Então assim eu consigo rever os estudos, por exemplo, se eu quero rever uma matéria. Seria muito difícil achar a matéria que eu quero no caderno, mas no digital, pra mim, fica uma organização mais fácil, mais visual e você consegue ver os conteúdos de uma melhor forma.

P: Então pelo que eu estou entendendo, você revisita suas anotações sempre, é isso?

T: Sim. É importante ficar revendo a matéria, porque é conhecimento, né? 
P: Você costuma compartilhar seu caderno digital entre seu grupo de amigos ou entre o pessoal da sua sala?

T: No meu caso fica só pra mim mesmo, mas eu estou no grupo da sala. Eu não sou o mais sociável, mas de qualquer forma, quando eles têm alguma dúvida e perguntam... Então não é uma questão de distribuir as anotações, mas a questão de entender a matéria e perguntar para os outros.

P: Você considera que os cadernos e os tablets como materiais importantes para a escola?

T: Sobre o caderno, eu prefiro mais a apostila, porque a apostila tem o conteúdo, então você não precisa ficar copiando. Eu acho que copiar leva um tempo muito grande, mas, por outro lado, você pratica sua escrita e seu vocabulário copiando e escrevendo com as suas palavras. O IPad é importante, né? Quem consegue ter um IPad ou tablet consegue armazenar os dados de uma forma muito mais organizada e sem o risco de perder. Por exemplo, o livro digital que a gente tem, a gente consegue acessar, fazer as atividades e que você não consegue fazer num livro físico. Por exemplo, em matérias de línguas, espanhol e inglês, você consegue ouvir o material, ouvir os diálogos e praticar. Então eu acho bom ter os dois. Mas se possível, somente o IPad, né? Porque tem uma maior capacidade de organização e armazenamento.

P: Qual é a função do caderno e do IPad pra você? Para que eles servem?

T: O caderno eu uso mais para fazer anotação e o IPad eu uso mais para fazer as atividades e agora também para guardar as anotações. 


\section{APÊNDICE B - ENTREVISTA COM JULIA}

Pesquisadora: Quais são os materiais que você usa para fazer os registros da escola?

Julia: Tudo IPad. Eu não uso mais caderno.

P: Por quê?

J: Porque eu acho que é mais rápido e mais prático e a própria Marina, quando gravava aula, ela usava um aplicativo e eu não sabia qual era. Em uma aula eu consegui ver o nome e aí eu baixei, mostrei para as minhas amigas e a gente está usando.

P: E você já usava o IPad para fazer suas anotações antes da quarentena?

$\mathrm{J}$ : Eu usava, mas para fazer resumo eu sempre usava o caderno normal. Foi na quarentena que eu comecei a usar o IPad.

P: Você acha que mudou a maneira como você fazia os seus registros antes e depois da quarentena.

J: Sim, muito. Ano passado eu só usava caderno, eu não tinha nem esse aplicativo que eu uso hoje. Foi nesse ano que eu comecei a usar só o IPad.

P: E antes você usava o IPad para quê?

J: Eu usava para a apostila digital, Kahoots e outros aplicativos do Band.

P: E agora além disso, você também usa para os seus registros. Certo?

$\mathrm{J}$ : Isso.

P: Você acha que mudar do caderno para o IPad fez com que você também mudasse a maneira de registrar?

J: Eu acho que com o IPad é melhor, porque quando você quer apagar alguma coisa é mais fácil, se quer mudar as coisas de lugar, organizar... Tipo, atividade que as professoras passam um modelo, eu faço tudo pelo IPad, eu passo pra esse aplicativo, eu não imprimo mais igual fazia antes.

P: E suas anotações, você sente que elas ficaram diferentes?

$\mathrm{J}$ : Ah, elas ficaram mais bonitas. Agora eu tenho imagem, eu tiro print da aula e coloco, fica mais legal de estudar por elas. Às vezes eu tiro print do vídeo, do Power Point, às vezes eu pego da internet, depende.

P: Você insere as imagens nos seus resumos, é isso?

$\mathrm{J}$ : Aham...

P: E o que você costuma registrar? 
J: Depende da matéria. Nas matérias que eu tenho mais dificuldade, eu costumo anotar quase tudo o que a professora fala na aula. As que eu tenho menos eu não costumo anotar tanta coisa, eu nem anoto, às vezes.

$\mathrm{P}: \mathrm{E}$ você costuma retomar esses seus registros?

$\mathrm{J}$ : Eu anoto durante as aulas do bimestre e aí quando chega mais perto das provas bimestrais eu releio. Pra estudar mesmo.

P: Você considera que os cadernos são um material importante para a escola?

J: O caderno físico ocupa peso na mala. Ele não é mais necessário, porque tem que carregar o estojo, o caderno, os livros, as folhas, a pasta. No IPad é tudo um só.

P: E os tablets?

J: Sim! Eu só uso ele.

P: Você compartilha seu caderno digital?

$\mathrm{J}$ : Ah, depende... Tem matérias que eu mando alguns resumos para as minhas amigas, como tem outras que eu não mando os resumos.

P: Suas amigas também têm usado apenas o IPad como você?

$\mathrm{J}$ : Todas as que eu sou mais próxima e as que a gente conversa sobre o assunto, todo mundo usa esse mesmo aplicativo.

P: Qual é o aplicativo?

J: É o Good Notes.

P: Qual é a função desses materiais para você?

J: Para facilitar, para não ter que levar tanto material, para deixar tudo mais organizado, mais colorido, com imagens e melhor para estudar. 


\section{APÊNDICE C - ENTREVISTA COM GABRIELA}

Pesquisadora: Quais são os materiais que você utiliza para fazer os seus registros da escola? Gabriela: Para fazer os registros da escola em si eu uso mais caderno físico mesmo, mas quando eu estou estudando, que são os estudos pessoais, esse ano eu comecei a usar muito o IPad. Na quarentena eu vi a necessidade de começar a usar a Apple Pencil para fazer os resumos, então eu ganhei uma Apple Pencil na quarentena. Antes eu não usava. Atualmente eu uso muito mais para fazer os resumos da escola o IPad. Mas para anotar as coisas em aula eu uso o caderno mesmo.

P: Por que você faz essa distinção? Tem alguma justificativa?

G: Então... Na verdade como eu ganhei a Apple Pencil já no final do terceiro bimestre... Eu comecei a usar agora. Estou aprendendo ainda. Como eu já usava os cadernos e tal, era mais o costume. Mas para o ano que vem é uma coisa que eu até já pretendo. Eu pretendo comprar menos cadernos, porque eu percebi que esse ano eu acabei utilizando muito menos do que se eu já tivesse a Apple Pencil. Então, como eu já tenho, eu acho que no ano que vem eu vou comprar menos cadernos para aproveitar mesmo. Então é por isso que eu faço essa diferenciação. No IPad é mais fácil.

P: O que você acha mais fácil?

G: Por exemplo, muitas vezes eu tenho que estudar em lugares que não necessariamente eu tenho uma mesa. Não na minha casa, na minha casa eu tenho um ambiente em que eu posso apoiar, mas quando eu estou, às vezes, fora de casa ou em um lugar mesmo que eu não teria como estudar, com a Apple Pencil é muito mais fácil, porque eu não preciso apoiar em nenhum lugar. Também eu tenho todas as minhas canetas, todas as minhas cores em um lugar só, então eu não preciso levar mil materiais. É muito mais prático pra mim.

P: Como mudou a maneira como você faz os seus registros antes da quarentena e agora com esse período da escola online?

G: Antes da quarentena eu imprimia muito papel. Nossa! Eram pastas e pastas!!! Mas agora na quarentena, como a gente tem tudo em PDF e eu vou ter que mandar para o professor, então para o professor é melhor se já estiver no IPad, eu comecei a fazer... Eu acho que nem tenho nenhum papel mesmo, físico, porque eu estou fazendo a maioria das coisas pelo IPad mesmo. A maioria das coisas ou digitando ou a caneta. A maioria eu estou fazendo assim.

P: O que você registra também mudou?

G: No IPad eu sinto que eu consigo soltar um pouco mais a minha criatividade no quesito de usar mais cores, colocar mais desenhos, mais imagens, porque se eu fosse fazer no caderno, eu 
teria que imprimir, e todo esse trabalho acaba desanimando de realmente imprimir. Só que no IPad é só você adicionar, então eu acho que os meus resumos do IPad e os meus registros em geral acabam tendo muito mais coisas gráficas mesmo, acabo fazendo mais desenhos e eu acho que visualmente eles ficam mais organizados, porque se eu errar eu não preciso rasurar, eu apago. Eu acho que isso deixa mais bonitinho visualmente.

P: Qual programa você usa?

G: Eu uso o Good Notes para anotar as coisas e responder os PDFs. Se às vezes eu quero fazer um desenho que eu quero que fique um pouco mais especial eu uso um outro aplicativo que chama SketchBook.

P: Você que faz os desenhos e cuida da parte gráfica ou pega desenhos da internet?

G: Depende. Principalmente em Ciências eu fiz muitos desenhos, porque tinha que representar as coisas, fazer setinhas, então eu pegava bastante desenho que eu realmente tinha feito, mas às vezes quando eu tenho, por exemplo, geografia, história, que precisa marcar coisa em mapa, então eu pego um mapa da Internet e marco com a caneta.

P: Então pelo que você está me contando têm diferenças entre suas anotações do tablet e do caderno.

G: Sim!!

P: E o que você costuma registrar?

G: Pra mim depende um pouco da matéria. Tem algumas matérias que os professores antes do ensino à distância já pediam para a gente registrar, então como fazia parte do curso, eu optei por continuar registrando e copiando dos Power Points, porque na minha visão os professores tinham algum motivo para pedir, já que eles já disponibilizavam os Power Points. Então para a minha fixação eu anoto de algumas matérias os Power Points, mas para estudar mesmo eu pego basicamente todas as informações que a gente tem e vou fazendo as anotações para eu entender mesmo a matéria. Então são esses dois principais. No IPad eu faço só baseado no que eu preciso para eu entender e as cópias mesmo eu faço nos cadernos físicos.

P: Pelo o que eu estou entendendo durante as aulas você anota tudo no seu caderno físico.

G: Isso! Às vezes eu também anoto coisas que o professor fala, eu acabo pegando e anotando e aí depois eu organizo no IPad, às vezes no caderno físico.

P: Você costuma compartilhar seu caderno digital com outras pessoas ou recebe partes dos cadernos de outros colegas?

G: Olha, por enquanto eu não compartilho o caderno com outras pessoas, mas eu tenho uma irmã que é mais nova do que eu e ela fica com os meus cadernos antigos, que eu usei para estudar. Eu acho que seria mais fácil, mas a gente só vai descobrir isso quando ela tiver no $7^{\circ}$ 
ano, mas eu acho que seria mais fácil para eu mandar pra ela, porque aí ela pode editar, se ela quiser alterar alguma coisa. Então eu acho que no futuro ela vai aproveitar bastante os cadernos já digitalizados.

P: Você retoma os seus registros? Você os relê? Você me contou que tem registros no caderno físico e também no digital, em que momento você retoma cada um deles?

G: A minha ordem cronológica é: primeiro faço os registros da aula que o professor mandou no caderno físico e aí eu pego o IPad e eu anoto as coisas que são relacionadas à aula para eu entender melhor a matéria e aí depois, quando eu estou próxima à avaliação ou se eu estou fazendo alguma atividade e eu não entendi, eu volto para esses resumos que eu fiz para mim mesma no IPad, e eu consulto para entender melhor.

P: Você considera que o caderno é um material importante para a escola?

G: Olha, eu sou suspeita para falar porque antes eu era um pouco "Nossa, mas escrever no IPad...” Mas hoje em dia, eu vejo que na minha opinião a gente não precisa tanto dos cadernos, porque os IPads acabam sendo mais práticos e, além de serem mais ecológicos, pensando no dinheiro, a gente acaba tendo que gastar menos, porque a gente não tem que ficar comprando material, cadernos. Eu uso um pouco de cada um, mas cada vez mais eu uso menos o caderno. Se eu fosse comparar o meu caderno no $1^{\circ}$ bimestre, quando eu ainda não tinha a Apple Pencil, ele está superlotado, mas agora desses bimestres, eles estão mais vazios, porque eu estou passando as coisas para o IPad, porque pra mim é mais fácil. Então eu acho que com o tempo, eu estou deixando de usar um pouco os cadernos e passando para os IPads.

P: Então o Apple Pencil foi determinante pra essa mudança? Você acha que se não fosse o Apple Pencil essa mudança não seria tão interessante?

G: Eu já olhava muito na internet as pessoas usando a Apple Pencil e pensava "Nossa!! Que incrível", só que era uma coisa que eu precisava ter certeza de que eu queria. Então meus pais, para testarem se era uma coisa que eu realmente queria, que era viável pra mim, eles me deram, eu não sei se você sabe, mas umas canetinhas que tem uma ponta para mexer no IPad e não são Apple Pencil. São canetas que de um lado são esferográficas e de outro são para mexer no IPad. Eu não me adaptei tão bem essas canetas, porque a ponta delas é meio mole, então quando ia escrever minha letra ficava um pouco estranha, mas como os meus pais viram que eu estava usando bastante, a gente optou pela Apple Pencil, porque foi uma coisa que eu percebi que estava sendo importante. Foi mais ou menos assim.

P: Qual é a função desses materiais para você? Para que eles servem?

G: Principalmente para eu poder entender as coisas, então pra mim, se eu não faço as coisas escrevendo, tanto no IPad ou no próprio caderno físico, eu não entendo direito o conteúdo. Eu 
sou uma pessoa bem que precisa escrever e ver para entender e aprender. Então pra mim eu gosto muito de escrever à mão, porque quando eu digito eu sinto que eu fixo pior a matéria, e quando eu escrevo à mão com cor, com desenho e essas coisas eu acho que eu lembro melhor. Então eu acho que é basicamente essa importância pra mim dos cadernos e IPads. 


\section{APÊNDICE D - ENTREVISTA COM VALENTINA}

Pesquisadora: Quais são os materiais que você usa para fazer os seus registros? Por quê? Valentina: Para registrar as aulas eu compro no começo do ano um caderno para cada matéria, porque eu acho que fica mais organizado e aí eu faço os registros que a professora passa, eu anoto algumas coisas que ela fala que não está escrito na lousa, por exemplo, eu anoto para lembrar. Para estudar para a prova, eu comprei no começo do ano em uma papelaria que fica bem perto da escola uns cadernos que não são pequenos, mas eles são bem leves, com capa bem fina, tem um plástico na frente, e que eu comprei 7 deles pra estudar para cada matéria. Então eu uso cada caderno com cada cor diferente para estudar para cada matéria, porque eu acho que fica mais organizado assim. Como eu pensava também que a gente ia para a escola esse ano, eu tinha, no ano passado um caderno bem grande e bem pesado que era para todas as matérias, mas era meio ruim de levar, porque eu levava todos os dias das provas, para dar uma revisada na perua, quando eu chegava e era muito pesado, então eu comprei esses pra ficar mais leve.

P: E você também usa tablet?

V: Assim, para estudar, para registrar mesmo, eu não uso muito, porque eu fico meio confusa. P: Por que você prefere fazer os seus registros no caderno?

V: Então, ano passado eu tentei fazer no IPad, mas não deu certo, porque eu não sabia onde estava, eu não achava, não dava certo. A agenda eu também tenho que ter a física, porque no IPad eles até ensinaram como usar o calendário, mas eu não consigo muito, porque eu já estava acostumada. Como na minha escola antiga a gente nem podia levar aparelhos eletrônicos, só tinha caderno físico para tudo, eu acho que eu já me acostumei assim.

P: Você acha que mudou o jeito que você fazia as anotações antes da pandemia e durante a pandemia?

$\mathrm{V}$ : Eu acho que agora que a gente tem acesso às aulas tem mais coisa para escrever, retomar $\mathrm{e}$ fixar mais na cabeça. Então eu escrevo um pouco mais de coisas, tem mais conteúdo para você lembrar durante as aulas. Eu revejo normalmente as aulas para estudar, então tem mais coisas para anotar. Eu anoto mais coisas agora, mas sempre anotei bastante coisa para estudar.

P: E o que você costuma registrar nos cadernos?

$\mathrm{V}$ : Eu registro um resumo, só que bem explicadinho de cada tópico que a gente aprendeu. Eu não fico colocando muitos exemplos. Eu coloco um exemplo a cada tópico que a gente aprendeu, faço bastante esquema também, mas eu prefiro escrever ou em tópicos ou um texto mesmo e ir grifando as partes mais importantes.

P: Isso você faz durante as aulas mesmo ou depois de assistir, em um momento de estudo? 
$\mathrm{V}$ : Eu primeiro assisto as aulas e depois que acaba eu vou voltando e pausando nas telas que a professora mostra e registro, mas durante as aulas eu não registro muita coisa. Eu registro muito mais para estudar para a prova do que durante as aulas.

P: E como você fazia antes na escola? Antes não tinha vídeo para voltar e assistir de novo.

$\mathrm{V}$ : Eu anotava o que a professora pedia para anotar na lousa, igual eu fazia no começo desse ano e aí eu ia estudar para a prova eu fazia bastante atividades e resumo, mas não muito. Ano passado eu não fazia muito resumo, eu estudava mais fazendo exercício, porque eu já tinha meu resumo. Aqui no EAD eu não costumo mais fazer resumo durante as aulas, é mais pra prova mesmo.

P: Você já falou um pouquinho sobre isso, mas deixa ver se eu entendi. Você faz os seus resumos perto das avaliações e retoma para estudar para as provas, é isso?

$\mathrm{V}: \operatorname{Sim}$ !

P: E quando você ia para a escola presencialmente, em que momento você retomava as suas anotações de aula?

V: Para estudar para as provas também. Às vezes eu até anotava de novo. Outra coisa do porquê eu não uso muito o IPad para fazer anotação, principalmente para a prova, porque eu acho que digitando eu não fixo muito o conteúdo na minha cabeça. Então eu acho que quando eu anoto, fica bem mais claro, eu entendo mais também. Então eu prefiro e sempre preferi anotar no caderno mesmo.

P: Você considera que o caderno é um material importante?

V: Muito importante!!! Nossa! Não sei como eu estudaria sem o caderno!

P: E o tablet, você considera um material importante?

V: Também é muito importante, porque a gente tem as apostilas digitais, tem o Moodle, que a gente assiste as aulas, mas até para as aulas presenciais também era bem importante, porque tinham vários aplicativos que a gente tinha que usar, então ele é muito importante também.

P: Qual é a função desses materiais para você?

V: O caderno eu uso para fazer meus registros e o IPad eu uso bastante para fazer atividade, porque eu abro a apostila digital no IPad e tiro print e aí eu vou escrevendo com uma canetinha.

P: Com o Apple Pencil?

V: Não, porque o meu IPad não dá para usar, é incompatível. Eu uso uma canetinha de borracha, que tem formato de giz de cera da Crayola.

P: Gostaria de ver um pouquinho dos seus cadernos...

V: Nossa, no ano passado, durante as aulas eu fazia tudo muito colorido, mas aí eu percebia que eu me atrasava demais e estava acabando a aula e eu ainda estava no título ainda. 
P: Você fazia lettering?

V: Sim, mas eu não sabia fazer direito... Ficava muito estranho! Eu tirava foto da lousa e copiava em casa, mas esse ano eu mudei. Eu fazia na escola sem canetinha praticamente, só com a caneta colorida, às vezes, mas nada demais. Para prova eu também não faço muito, porque eu perdia muito tempo fazendo isso. Então esse ano eu parei de fazer. Eu uso cores para destacar. 


\section{APÊNDICE E - ENTREVISTA COM ROBERTA}

Pesquisadora: Quais são os materiais que você usa para fazer os registros da escola?

Roberta: Para fazer os meus registros eu sempre pesquiso bastante em vários sites como Brasil Escola, mas primeiramente eu sempre olho a apostila digital, porque pra mim é o recurso que mais ajuda porque tem todas as informações que a gente precisa para as provas PGI e esse tipo de coisa. Para facilitar eu pego as minhas anotações do caderno, que são aqueles slides que os professores passam nas aulas e resumo eles em uma ficha, porque na hora de estudar para a prova eu acho que fica menos cansativo e mais rápido.

P: Então você faz duas coisas pelo que eu estou entendendo: faz as suas anotações durante a aula daquilo que está no Power Point e do que você está ouvindo e depois você pega todas essas informações e faz um resumo numa ficha. É isso?

R: É!!

P: E você faz todo esse processo no caderno ou no tablet?

$\mathrm{R}$ : Eu prefiro fazer no papel escrito mesmo, porque eu não sou uma pessoa muito de tablet assim... Na pandemia eu tive que me adaptar, mas eu acabei fazendo alguns resumos no Word e em outras plataformas, mas eu continuo fazendo mais no papel mesmo.

P: E por que você prefere no papel?

R: Eu prefiro o papel porque não sei... Me dá a sensação de que eu estou escrevendo e nossa, eu estou memorizando e no IPad não dá essa sensação. No papel eu consigo fazer as coisas com mais facilidade, escrever mais rápido, acho mais fácil.

P: Você sente que durante o ensino remoto mudou a maneira de fazer seus registros?

R: Com certeza mudou! Com certeza! Porque indo presencialmente a gente usava Word e Power Point normal, só que para apresentações e esse tipo de coisa, o resto a gente escrevia no papel. Agora a maioria dos trabalhos... tirar foto às vezes não fica muito claro o que está escrito, então a gente já faz no Word, essas coisas. Na pandemia eu aprendi a mexer muito melhor, isso foi um impacto positivo, porque eu sei que provavelmente na minha carreira no futuro eu vou ter que usar essas plataformas.

P: Então pelo que você está me dizendo você usa bastante o tablet para resolver os exercícios, fazer as atividades para não precisar imprimir e tirar foto depois, mas as suas anotações e registros você acaba usando o caderno. É isso?

R: Isso!

P: Que aplicativo você usa?

R: A Marina já recomendou o Good Notes, só que eu não uso ele, eu uso o Acrobat. 
P: E você acha que você mudou a maneira como você faz seus registros durante esse período de quarentena?

R: Antes eu fazia um resumo grande, nem sei se podia ser chamado de resumo. Era um resumo grandinho. Só que na quarentena eu comecei a fazer tanto resumo, mais tanto resumo que eu peguei o jeito e agora diminuiu e agora eu acho muito mais fácil. Eu pego a matéria muito mais fácil fazendo resumo. Eu tenho uma caixa de resumo. Eu sempre fiz resumo desde que entrei no Band, mas eu tenho uma caixa de resumo só desse ano e aí me ajudou muito.

P: E como são esses resumos e registros?

R: O título é sempre colorido de qualquer matéria. Uma coisa que eu gosto de fazer para me organizar é uma cor para cada matéria, porque já aconteceu no ano passado: Ah! Vou pegar esse que é da aula de espanhol, aí chega na hora da aula e não é de espanhol, era de matemática. Então eu gosto de fazer isso, cada cor uma matéria e os títulos sempre são chamativos, eu faço ele bem grande para eu nem precisar pegar, olhar, bater o olho e já saber o que é. E eu gosto de fazer colorido, porque me dá mais vontade de estudar. Eu não gosto de ver o papel todo azul ou todo preto.

P: Você compartilha seus resumos com alguém?

R: Às vezes eu até resumo com os meus amigos, porque a gente acha legal esse negócio de trabalho em grupo. A gente se dá bem, sabe? Às vezes eles falam: "Vocês querem tal resumo? Eu fiz, vocês querem foto?” e aí eu falo “Ah, eu fiz também, vocês querem?” Algumas vezes nós fizemos juntos, porque na pandemia tá difícil, né?

P: O que você costuma registrar?

R: No meu caderno eu geralmente escrevo as palavras-chave, as coisas mais chave, literalmente, porque eu acho que não adianta escrever tudo o que o professor fala, eu vou perder muito tempo. Tanto que a Marina fala nas videoaulas "Gente, escrevam a coisa mais importante", aí eu escrevo geralmente os slides, eles fazem um mapa mental que me ajuda bastante. Porque eu sou uma pessoa mais de... eu gosto de ver coisas coloridas, com flechas. Tanto que quando eu vou ler um livro... não é que eu não gosto de ler livro que não tem imagem, mas se aquele livro tem pelo menos uma imagem no primeiro capítulo eu gosto. Tem que ter pelo menos uma imagem. P: Você relê os seus registros do caderno e seus resumos? Em que momentos?

R: Sempre que eu vou escrever outra anotação no caderno eu leio basicamente tudo, porque como eu vou escrever uma nova coisa, tudo está conectado e se eu não entender uma coisa do começo do ano eu não vou entender essa que eu estou aprendendo agora. Aí eu revejo tudo do caderno, também, geralmente, não tem muita coisa no caderno, é mais exercício e aí eu não 
anoto, só faço o exercício. E o resumo eu sempre releio para as provinhas, testes, essas coisas mais notas assim...

P: Você acha que seus registros mudam de uma disciplina para outra?

R: Percebo sim, porque às vezes tem professor que passa uma matéria e aumenta muito, nem sei explicar, mas eles passam muitas páginas, mais muitas páginas e muitos exercícios e muitos sei lá, o que e acaba que o resumo não fica um resumo às vezes. Nem tem como resumir. Mas outros professores têm, por exemplo Português. Em Português eu consigo resumir bem. Matemática ninguém resume porque é exercício, mas eu resumo tudo, porque eu acho mais fácil. Até a Matemática! Eu pego a ficha, escrevo e aí eu coloco as contas mais... "essa eu tenho que saber" e aí eu coloco, faço, vejo se está certo e pronto.

P: Você considera que o caderno é um material importante na escola?

R: Muito. Muito, porque tem gente que aprende melhor escutando ou falando sozinho, mas eu sou uma pessoa que aprende melhor lendo e escrevendo, então eu acho que pra mim se não tivesse caderno eu estaria bem ruim nas matérias.

P: E o tablet, é um material importante na escola?

R: Também, porque eu acho que mais pra frente provavelmente não vai ter muito caderno. Infelizmente. E é bom a gente já ir se adaptando com a tecnologia nova e o tablet acho muito importante, porque é mais fácil para pesquisar as coisas e é isso mesmo.

P: Por que você acha que não terá mais caderno daqui algum tempo?

R: Porque tá tudo ficando... Minha irmã de cinco anos está fazendo coisas que eu aprendi com dez anos. Eu acho que está avançando muito rápido, provavelmente não vai ter mais caderno.

Só vai ser caderno digital.

P: Qual é a função desses materiais para você?

R: Para facilitar o estudo do aluno.

P: Os dois têm essa mesma função para você?

$\mathrm{R}$ : Acho que sim, mas de maneiras diferentes. O caderno me ajuda a memorizar, eu gosto de escrever, a aprender, realmente, mais a matéria do professor. O IPad me ajuda a aprofundar o assunto, porque eu consigo pesquisar, ver a apostila digital, essas coisas.

P: Você usa o Apple Pencil?

M: Eu não uso a Apple Pencil, mas eu uso duas canetas que minha mãe ganhou no trabalho e eu acho bem boas. Elas ajudam. Quando eu faço o exercício, eu geralmente não imprimo os exercícios, porque minha impressora é meio doida aí eu faço no IPad com a canetinha, mas mesmo assim eu prefiro o papel. 


\section{APÊNDICE F - ENTREVISTA COM LORENA}

Pesquisadora: Quais são os materiais que você usa para fazer os seus registros?

Lorena: Hoje em dia eu uso caderno normal de 10 matérias e eu costumo ir fazendo os resumos para as provas nesse caderno, só que já foi diferente. No começo desse ano a gente fazia as anotações na aula, o que era melhor na minha opinião, os cadernos ficavam separados. Hoje em dia, eu acabei comprando um caderno único e acabo fazendo todos os resumos pra prova no mesmo, só que também foi diferente do ano passado. No ano passado eu usava essas fichas, sabe? Mas hoje em dia eu faço tudo no caderno de 10 matérias. Inclusive é uma coisa que eu queria comentar quando eu fiquei sabendo do assunto da nossa conversa, que eu não sei se foi coisa da quarentena, mas no começo do ano eu costumava fazer meus resumos mais bonitinhos, sabe? Eu não sei o que aconteceu na quarentena, eu acho que eu comecei a considerar mais a praticidade e fui só fazendo, não tão bonitinho como eu fazia antes.

P: O que você considera "bonitinho"?

L: No começo do ano eu fazia um título mais elaborado, até lettering, mas olha esse de agora, pra prova que eu acabei de estudar... (mostra o registro) mais básico. Para as provas bimestrais, deixa eu te mostrar... Enquanto eu estudava História, eu resolvi fazer uma coisa mais bonitinha. Como em História é muita informação, estava ficando uma coisa muito pesada, muito escrito, escrito, escrito e isso estava me cansando um pouco, aí eu falei: “Ah! Eu vou fazer um pouquinho diferente e depois eu volto para como eu estava fazendo antes." Sabe, acho que só para dar uma organizada.

P: Por que você prefere fazer seus registros no caderno físico ao tablet, que é um material obrigatório da escola em que você estuda?

L: Eu acho que é uma coisa de hábito mesmo, sabe? Eu me acostumei a fazer desse jeito. Nas aulas da Marina ela usa um aplicativo bem legal e tudo. Eu até baixei ele, mas só usei para testar, eu queria explorar, só que eu prefiro fazer no caderno mesmo por uma questão de hábito. P: Tem mais alguma coisa que você percebe de mudança na maneira de fazer seus registros durante esse período de ensino remoto?

L: Olha eu acho que em questão do lugar onde eu faço as anotações não, mas como eu fazia as anotações, deu pra ver que mudou bastante.

P: Então as mudanças têm a ver com a praticidade, né?

L: É, exatamente!

P: Você falou no começo da conversa que antes fazia as anotações durante a aula e que agora é diferente. Conta um pouquinho mais sobre isso. 
L: Antes a gente copiava o que os professores escreviam ou colocavam no Power Point, só que na quarentena eu comecei a fazer as minhas anotações, eu ouvia a aula e ia escrevendo o que eu achava importante.

P: Você fazia isso enquanto assistia a videoaula?

L: É, às vezes eu pausava porque eu não sou tão rápida assim. A melhor vantagem foi de poder na hora de estudar ver de novo as aulas, porque, por exemplo, quando eu estava estudando História... uma coisa que eu acho complicado em estudar História é ficar lendo o texto, eu li né, mas e daí?! Com as aulas em vídeo facilitou bastante, porque eu consiga ter alguém me explicando enquanto eu anotava, voltava, e ficava uma coisa mais clara do que só ficar lendo uma apostila.

P: Você faz os seus resumos depois ou suas próprias anotações já são o resumo?

$\mathrm{L}$ : Eu costumo fazer os resumos para estudar, como uma forma de estudo, porque é como eu consigo guardar, sabe?

P: E em que momento você faz os resumos?

L: Às vezes, na quarentena, eu fazia anotações durante a aula, mas eu sempre faço, antes de alguma prova, o resumo da matéria, entendeu?

P: O que você costuma registrar nos seus cadernos?

L: Isso é uma coisa que eu acho que eu tenho que melhorar, é uma coisa que com o tempo talvez eu consiga, tendo prática. Eu tenho muita dificuldade em separar o que é muito importante do que não é tão importante. Inclusive, é uma coisa a ser comentada, que na quarentena eu acho que consegui melhorar isso, porque antes eu queria anotar muita coisa. Hoje em dia eu consigo separar melhor o que é importante e o que não é tão importante assim, só que eu ainda tenho um pouco de dificuldade pra isso, mas né, vamos trabalhando...

P: Você relê os seus registros?

L: Às vezes, o que eu fiz para estudar para uma provinha e depois uma bimestral, por exemplo? P: Pode me contar de cada tipo de registro.

L: Às vezes, é bem raro, quando eu lembro que tem tal informação em tal lugar, aí eu vou ver. Sei lá, vai ter uma prova, eu quero lembrar de alguma coisa que não lembro de jeito nenhum, aí eu vou lá e dou uma olhadinha, mas isso acontece muito pouco. Mas, por exemplo, ontem enquanto eu estava estudando para a última prova, eu estava fazendo um resumo de um tópico de revisão e aí eu fui olhar os registros anteriores, porque já estava um pouco em cima da hora e aí eu fui olhar o que eu tinha feito para a outra prova e isso me facilitou bastante, mas eu não costumo, quando eu estou fazendo resumo da mesma matéria, não costumo recorrer ao anterior, 
sabe? Eu faço de novo, porque é uma maneira de estudar. Hoje em dia eu costumo fixar bastante enquanto faço resumo.

P: Então pelo que você está me dizendo, você faz esses registros muito mais como um meio de estudo do que para guardar essas informações e anotações.

L: Exatamente.

P: Você compartilha seus resumos com alguém?

L: Não, mas se alguma pessoa tem alguma dúvida a gente vai lá e responde. Se alguém fala "Me ajuda em tal coisa?", a gente vai lá e se ajuda. Mas de resumo não...

P: Você considera que o caderno é um material importante na escola?

L: Nossa!!! Sim!!! Sem o caderno eu não ia conseguir fazer um resumo, não ia conseguir estudar, então...

P: E os tablets?

L: Ah... são, porque a gente pode ver os materiais por eles e pesquisar e fazer várias coisas. Mas eu acho que eu ainda prefiro usar os cadernos do que os tablets.

P: Você tem usado o tablet para resolver os exercícios e fazer as atividades?

L: Ah, isso foi uma mudança também. Eu fiz isso, principalmente para matemática. Algumas vezes eu fazia exercícios no papel mesmo, mas às vezes eu respondia no próprio IPad. Nessa questão eu acho melhor usar o IPad porque eu acho mais prático.

P: Você tem o Apple Pencil também?

L: Aham, sim.

P: Você acha que ela te ajuda?

L: Sim, eu acho mais fácil para resolver os exercícios, eu acho melhor no IPad do que no papel.

P: Qual é a função do caderno e do IPad para você?

L: Ah, os cadernos para estudar mesmo. Os tablets eu uso para estudar quando precisa e também para me divertir, ver série, filme.

Eu queria falar também que às vezes eu também uso Post-it para anotar algumas coisas. Às vezes eu também uso aqueles to do list, você conhece? Que você anota tudo e vai marcando, isso me ajudou muito. Tinha vezes eu ficava um desse tamanho (abre as mãos mostrando um tamanho grande de papel) e eu pensava "Nossa! Que legal!” A melhor coisa que pode acontecer no seu dia é ir marcando o que já fez. Falando dos Post-its mesmo, por exemplo, eu usei um dia desses para anotar um negócio de escala que eu não estava conseguindo memorizar, que era o tamanho real e o do desenho, a ordem que eles ficavam na conta. Aí eu fui lá, anotei, está até aqui no meu quarto, olha (vira a câmera para onde está colado o Post-it na parede) e aí eu deixei aqui e acho que é legal usar para lembrar de alguma coisa e deixar lá. 